

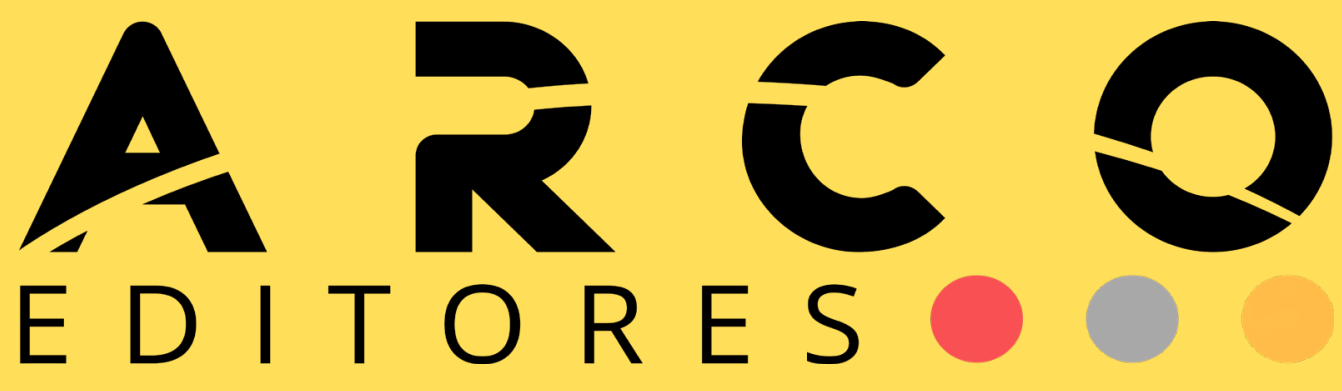

\title{
PESQUISA HISTÓRICA E ABORDAGENS MULTIDISCIPLINARES NO CAMPO CIENTÍFICO
}

\author{
Leandro Antônio dos Santos \\ Ranna lara de Pinho Chaves Almeida \\ [Organizadores]
}


Dados Internacionais de Catalogação na Publicação (CIP) (Câmara Brasileira do Livro, SP, Brasil)

Pesquisa histórica e abordagens multidisciplinares no campo científico [livro eletrônico] / organização Leandro Antônio dos Santos, Ranna Iara de Pinho Chaves Almeida. -- 1. ed. -Santa Maria, RS : Arco Editores, 2021. $\mathrm{PDF}$

ISBN $978-65-994306-0-2$

1. Pesquisa científica I. Santos, Leandro Antônio dos. II. Almeida, Ranna Iara de Pinho Chaves.

Índices para catálogo sistemático:

1. Pesquisa científica em educação 370.78

Aline Graziele Benitez - Bibliotecária - CRB-1/3129

\section{$10.48209 / 978-65-994306-0-2$}

1. ${ }^{\text {a }}$ Edição - Copyright@ 2021 dos/as autores/as. 


\section{CAPA}

Arco Editores.

\section{DIAGRAMAÇÃO E PROJETO GRÁFICO}

Gabriel Machado.

\section{REVISÃO}

Dos/as Autores/as.

\section{CONSELHO EDITORIAL}

Prof. Dr. Adilson Tadeu Basquerot e Silva - UNIDAVI/SC

http://lattes.cnpq.br/8318350738705473

Profa. Msc. Jesica Wendy Beltrán -UFCE- Colômbia

http://lattes.cnpq.br/0048679279914457

Profa. Dra Fabiane dos Santos Ramos UFSM- Santa Maria/RS

http://lattes.cnpq.br/0003382878348789

Dr. João Riél Manuel Nunes Vieira de Oliveira Brito -

UAL - Lisboa- Portugal.

http://lattes.cnpq.br/1347367542944960

Profa. Dra. Alessandra Regina Müller Germani -

UFFS- Passo Fundo/RS

http://lattes.cnpq.br/7956662371295912

Prof. Dr. Everton Bandeira Martins UFFS - Chapecó/SC

http://lattes.cnpq.br/9818548065077031

Prof. Dr. Erick Kader Callegaro Corrêa UFN- Santa Maria/RS

http://lattes.cnpq.br/2363988112549627

Prof. Dr. Pedro Henrique Witchs - UFES

- Vitória/ES

http://lattes.cnpq.br/3913436849859138

Prof. Dr.Thiago Ribeiro Rafagnin UFOB

http://lattes.cnpq.br/3377502960363268
Prof. Dr. Mateus Henrique Köhler UFSM- Santa Maria/RS

http://lattes.cnpq.br/5754140057757003

Profa. Dra. Liziany Müller Medeiros UFSM- Santa Maria/RS

http://lattes.cnpq.br/1486004582806497

Prof. Dr. Camilo Darsie de Souza UNISC- Santa Cruz do Sul/RS

http://lattes.cnpq.br/4407126331414

Prof. Dr. Dioni Paulo Pastorio - UFRGS Porto Alegre/RS

http://lattes.cnpq.br/7823646075456872

Prof. Dr. Leonardo Bigolin Jantsch -

UFSM- Palmeira das Missões/RS http://lattes.cnpq.br/0639803965762459

Prof. Dr. Leandro Antônio dos Santos -UFU- Uberlândia/MG

http://lattes.cnpq.br/4649031713685124

Dr. Rafael Nogueira Furtado UFJF- Juiz de Fora/MG

http://lattes.cnpq.br/9761786872182217

Profa. Dra. Angelita Zimmermann UFSM- Santa Maria/RS

http://lattes.cnpq.br/7548796037921237

Profa. Dra. Francielle Benini Agne Tybusch UFN- Santa Maria/RS http://lattes.cnpq.br/4400702817251869 


\section{PREFÁCIO}

A pesquisa científica nesse início de século XXI vem ganhando contornos cada vez mais multidisciplinares, ao comtemplar abordagens de pesquisa com a aproximação de disciplinas que tem em comum pensar a trajetória da civilização ocidental, em seus mais variados aspectos, desde o campo da cultura, passando pelos aspectos políticos, econômicos e sociais, ao pensar sobre as sensibilidades, do momento presente, e os direitos e deveres da ciência se manifestam em diferentes métodos que coincidem na maneira de interpretar o humano.

Nesse sentido esse e-book traz um ampliado espectro de abordagens no campo científico que se configuram como análises que revigoram o interesse de horizontes de percepção em torno da ciência histórica com variadas parcerias intelectuais com a Sociologia, Filosofia, Antropologia, Geografia, Letras, Educação, Linguística, Direito e Artes, que utilizem processos e instrumentos científicos, tais como: pesquisas que se voltem para a história política, ou nova história política (ação do Estado, ideologias políticas, partidos políticos, subjetividades no âmbito do político, movimentos sociais, etc), a história cultural ou nova história cultural (literatura, teatro, música, cinema e jornalismo, etc), história econômica e história social (cidade, família, biografias, instituições sociais, etc. As fronteiras entre campos científicos delimitados pela segmentação institucional e acadêmica se aproximam causando a intercessão de teorias e métodos que se justapõem ao pensar problemáticas do presente e do passado.

Essa necessidade de diálogos é cada vez mais inerente ao fazer científico, quando contribuições de variados intelectuais se entrecruzam na busca de novos objetos de pesquisa que se tornam fundamentais para a pluralidade do saber científico, e da abertura de formas inéditas de conhecimentos aplicados em suscitar o olhar sobre o que é apreensível na interpretação da sociedade do nosso presente. $O$ alargamento de possibilidades que se apresentam nos fazeres científicos torna-se possível ao ampliar territórios inexplorados, enriquecer os já existentes e incentivar os que ainda não são conhecidos, fazendo com que a ciência sempre busque se reinventar para que ela seja sempre pertinente as demandas da sociedade contemporânea. Por isso, só nos resta agradecê-lhe e recomendarmos firmemente a leitura.

A todos, uma ótima leitura!

Leandro Antônio dos Santos - UFU Ranna lara de Pinho Chaves Almeida - UFU Organizadores deste e-book. 


\section{SUMÁRIO}

"PAPARAGRAFIA"

TANIA VALENA DA SILVA NORONHA

A PESQUisa EM ARQUEOLOGIA NO BRASIL OITOCENTISTA..........20 DAYSE MARINHO MARTINS

NOTAS SOBRE A PRODUÇÃO HISTORIOGRÁFICA EM TEMPOS

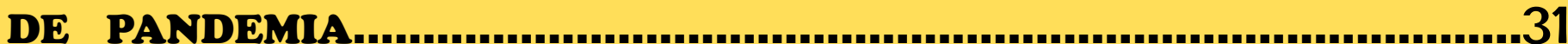

BRUNO CÉSAR PEREIRA

VANIA VAZ

PRÁticas SOCIALIZAdORAs E RELAÇÕES INTERGERACIONAIS: A CONTRIBUIÇÃo dOS AVÓS NA ESCOLARIZAÇÃo DE ESTUDANTES UNIVERSITÁRIOS

TATIANE KELLY PINTO DE CARVALHO

ELAINE GONÇALO BENTO

DENISE SILVA E SOUZA

ROSA MARIA DA EXALTAÇÃ COUTRIM

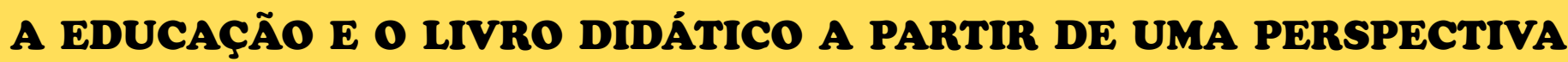
HISTÓRICA: 0 CASO DAS REPRESENTAÇÕES FEMININAS...............60

ARY ALBUQUERQUE CAVALCANTI JÚNIOR

GUILHERME NOGUEIRA M. MUZULON

A CIDADE E O FAZER OPERÁRIO: TECENDO TERRITORIALIDADES E REPRESENTAÇões do CENTRO À PERIFERIA, DO TRABALHO AO LAR (BELÉM-PA, 1930-1935).

JOSÉ IVANILSON DA LUZ RODRIGUES

JAIRO DA SILVA E SILVA 
As CRÔNICAS DE ENEIDA DE MORAES-JORNALISMO POLÍtico ATRAVESSADO PELO TESTEMUNHO LITERÁRIO.

MIRNA LÚCIA ARAUJO DE MORAES

VERA MARIA SEGURADO PIMENTEL

JOANA D'ARC: REPRESENTAÇÕES FEMININAS NA HISTORIOGRAFIA MEDIEVAL E NA ICONOGRAFIA 101

ANNA ORTIZ BORGES COELHO

YASMIM CARINA BASTOS RIBAS

A TRAJETÓRIA DE ROSALINA COELHO LISBOA (1900 1975)

YASMIM CARINA BASTOS RIBAS

ANNA ORTIZ BORGES COELHO

O ESPECTRO DA IMAGEM: SARTRE, HUSSERL E BERGSON 125

CAIO CÉSAR COSTA SANTOS

A TEMÁTICA DA HISTÓRIA E CULTURA AFRO-BRASILEIRA E INDÍGENA NOS LIVROS DIDÁTICOS DE HISTÓRIA NO ENSINO MÉDIO. 141

RAFAEL KUNST HAYGERT

PRISCILA GUALBERTO DE LIMA

A história local e a pesquisa em história da educạ̧ão: UMA ANÁlise dOCUMENTAL dA INSTRUÇÃo PÚBLICA dA PROVÍNCIA MARANHENSE

RICARDO COSTA DE SOUSA

UMA ANÁlise CRÍtica do PENSAMENTO de MICHEL FOUCAULT SOBRE A PRISÃO: FORMAS DE VIGIAR E PUNIR NO ATUAL SISTEMA PRISIONAL BRAsILEIRO EM CRISE 174

TAINE PIRES DUARTE 
A TERRITORIALIDAdE HISTÓRICA DA IMIGRAÇÃo JAPONESA EM PRESIDENTE PRUDENTE/SP

ADRIANO AMARO DE SOUSA

aplicạ̧ão do método lancaster nas aUlas de primeiras LETRAS (ALCÂNTARA,MA - I QUARTEL DO SÉCULO XIX)...........204 RICARDO COSTA DE SOUSA

A UTILIzạ̧ão de FOTOGRAFIAs COMO FORMA dE PREsERVAÇÃo E disseminação da história E MEMória lOCAL NA CIDAdE dE

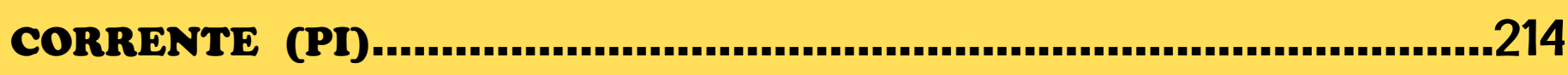

TEFISCHER HUANDERSON SOARES SOUSA

SOBRE OS ORGANIZADORES 


\section{$10.48209 / 978-65-994306-0-1$}

\section{“PAPARAGRAFIA"}

Tania Valena da Silva Noronha ${ }^{1}$

$1 \quad$ Graduada em Artes Visuais na Universidade Federal do Espírito Santo - UFES com experiência em desenho de observação de pessoas e ambientes, pintura figurativa, criação de personagens em histórias em quadrinhos; criadora de histórias infantis de forma oral. proprietária do ateliê AE-Produção e Arte. Idealizadora do vídeo documentário "Quem são esses capixabas"; Exposição individual de desenhos e de um diário gráfico feito para este fim com arames, rolhas de garrafas e tecidos reaproveitados na Dadá Galeria - UFES/2013; Premiada com a ilustração em conto do livro "Contos Capixabas para as Crianças do Mundo"-1980, Publicações de diversos desenhos em "A Gazetinha" - na década de 80.

Atualmente é funcionária do Museu de Arte do Espírito Santo Dionísio Del Santo -MAES 
Desde muito pequena eu sempre fui muito observadora e adorava desenhar os colegas na sala de aula em forma de caricatura. A falta de prática do tempo que fiquei parada deixou os meus traços duros e sem vida, Ao entrar na Universidade Federal do Espírito Santo - UFES eu tive o incentivo do professor Pedro Meyer Barreto, que elogiava sempre os meus desenhos de modelo vivo. Com isto, fui ganhando confiança em mim mesma. Mais tarde o professor Fernando Augusto falou sobre desenhar pessoas em lugares diversos em forma de diário. Eu não sabia do que se tratava e foi aí, então, que comecei a fazer os meus primeiros desenhos de observação com caneta nanquim que no final eu mesma me surpreendi com a capacidade de criação que até então, eu mesma não sabia que eu tinha. Deixei o nanquim e experimentei a caneta esferográfica preta que para a minha surpresa o resultado foi melhor do que eu esperava.

Os desenhos foram desenvolvidos nos mais diversos lugares: praia, lanchonete, padaria, bares, postos de saúde, aeroportos, nas ruas, na sala de aula, em escolas, creches e tantos outros lugares por onde passei. Desenhar pessoas e apresentar lugares, estes são os ideais que tento difundir com as minhas andanças, com muita audácia e muita coragem, deslocando-me entre identidades, explorando a plástica através do olhar e transportando para ao papel. Além disso, após a realização dos desenhos, eu faço uma observação crítica sobre os meus trabalhos, analisando os resultados, apurando cada linha que se forma e se atravessam entre si.

Desenhar pessoas me aguça o desejo de experimentação e de pesquisa, de conhecer as tantas identidades que se diferem no Brasil, em especial no Espírito Santo. Sendo assim, o diário gráfico surgiu como um meio de explorar as mais diversas características físicas, assim como tudo mais em sua volta formando uma composição.

As imagens expostas neste ensaio fazem parte de um acervo gráfico que desde 2012 vem sendo construído que se divide em desenhos em movimento e desenho estático. O primeiro refere-se nos desenhos realizados com o olhar em corpos em movimentos, de encontros e desencontros, de crianças brincando, de grupos de pessoas reunidas dançando ou durante uma luta de capoeira, de pessoas andando ou mesmo pessoas que mesmo paradas, conversando umas com as outras, movimen- 
tam a todo instante os braços ou as mãos. O segundo trata-se de desenhos com o olhar observando corpos estáticos e de movimentos leves, realizados em locais onde as pessoas se encontravam geralmente sozinhas fazendo um lanche numa padaria ou numa lanchonete, sentadas ou em pé, em pontos de ônibus e aeroportos, como tantos outros lugares onde foi possível realizar estes desenhos sem que houvesse qualquer problema quanto ao observado. Dentre os desenhos de corpos estáticos eu incluí dois de meus autorretratos que além de meu corpo, é revelado todo o ambiente onde eu me encontrava no momento. Para desenhar a mão que criava a imagem, a minha mão direita, eu tive que observar a minha mão esquerda e assim transmitir para o papel de forma espelhada.

Os desenhos apresentam diferentes tipos de traços classificados por mim em: leves, fortes e muito fortes. Os traços mais leves foram feitos em momento de tensão, onde eu tive que tomar muitos cuidados ao desenhar as pessoas que me olhavam desconfiadas e que para disfarçar eu tive que por várias vezes desviar o meu olhar das pessoas a quem eu desenhava. Os traços mais fortes foram desenhos realizados com firmeza e coragem e que me levaram a ser audaciosa e mais observadora. Já os traços muito fortes, são continuidades que dei em meus próprios desenhos que depois de prontos eu resolvi dar a eles um sombreamento ou uma escurecida nos traços.

Cada desenho não leva muito tempo para ser feito, a prática me trouxe a agilidade de transmitir para o papel tudo o que a minha mente consegue captar e se ocorre da pessoa sair do local no momento em que está sendo desenhada, a minha memória já consegue guardar detalhes por um período e com isto eu consigo concluir o desenho.

Em julho de 2013 eu tive a oportunidade de mostrar um pouco do meu trabalho para o público à partir de uma exposição individual realizada na Dedá Galeria - Centro de Artes - UFES, com o título deste Ensaio Visual. Este nome foi criado por um amigo do curso noturno de Artes Visuais, Renato Pignaton Firme, que comparou o meu trabalho com a de um paparazzo ${ }^{2}$, que fotografa pessoas famosas sem autoriza-

2 (no plural,paparazzi) é uma palavrada língua italiana utilizada para se designar osrepórteres que fotografampessoas famosas sem autorização, expondo em público as atividades que eles fazem em seu cotidiano. http://pt.wikipedia.org/wiki/Paparazzo 
ção das mesmas. Então ele teve a ideia de juntar parte da palavra paparazzo com a palavra grafia, criando o nome Paparagrafia. Este foi o nome escolhido para a exposição e o nome que adotei para todos os meus trabalhos de desenho de observação.

Figura 1: Momento de Liberdade em Praia de Camburi Vitória-ES/Brasil

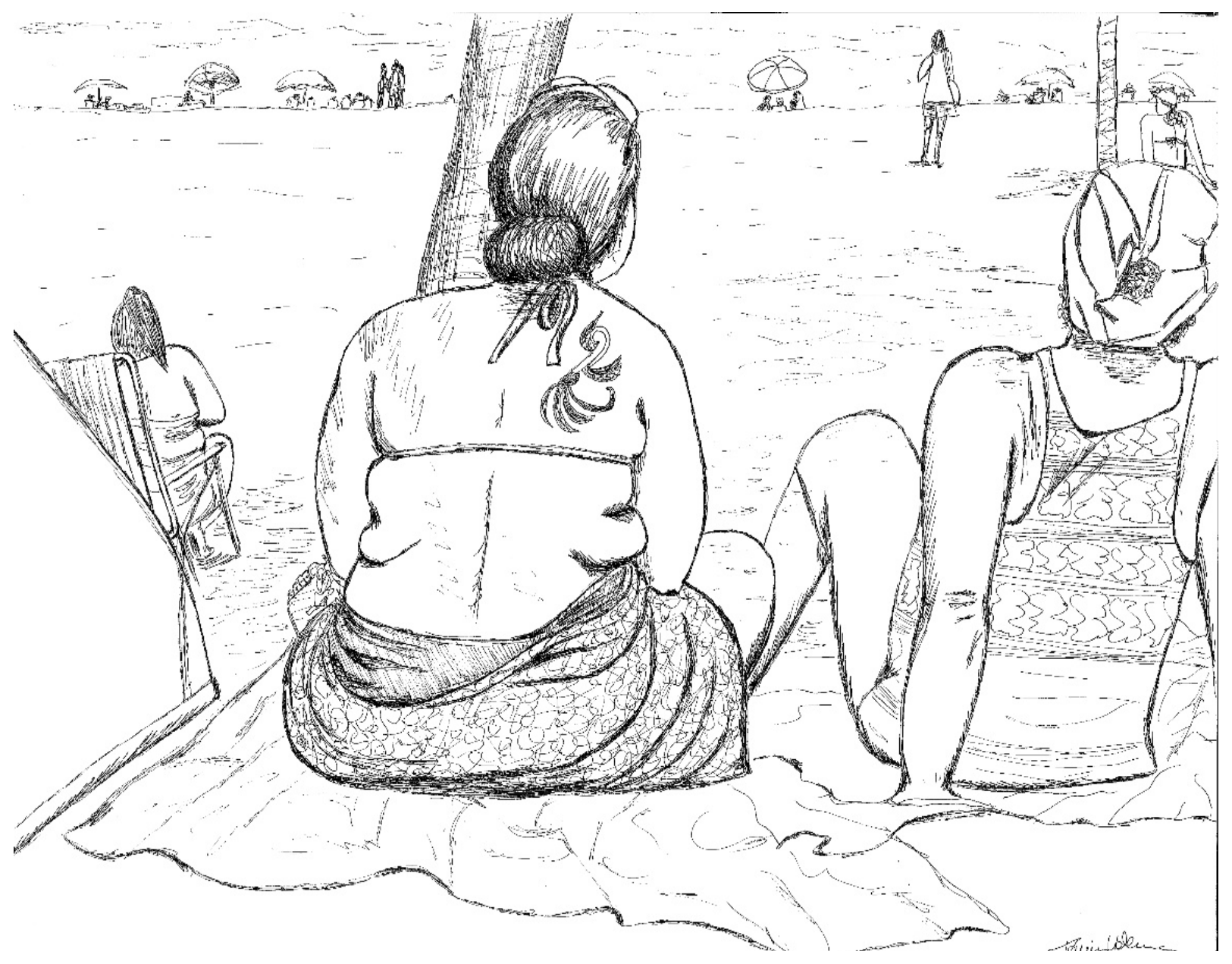

Sob a sombra do coqueiro, eu fiz a minha leitura visual que estava à minha frente, transferindo para o papel estas duas mulheres que muito me chamaram a atenção os ricos detalhes. Caneta nanquim preta sobre o papel. 
Figura 2: Pessoas na calçada

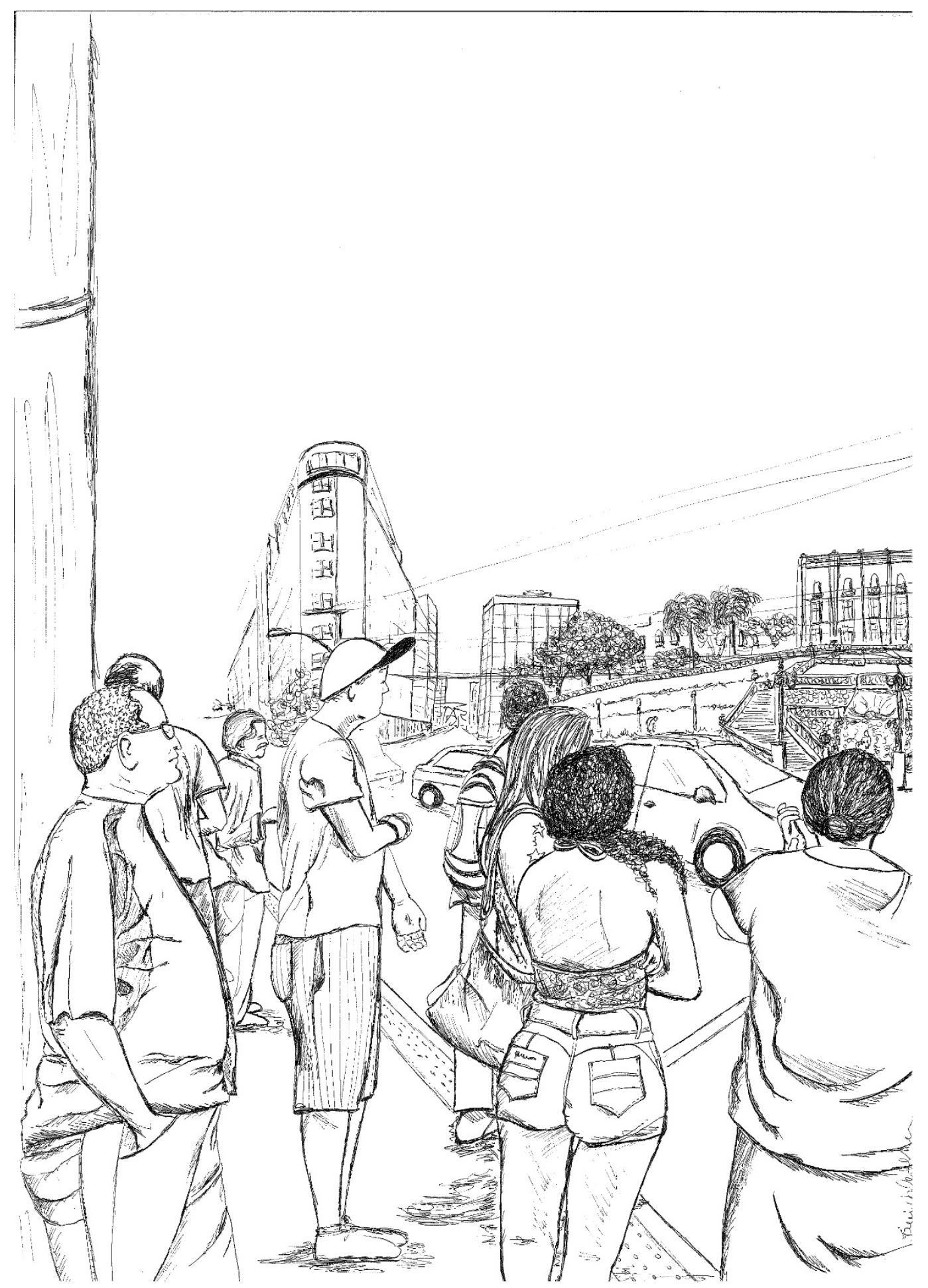

Achei muito interessante estas pessoas paradas, feito estátuas, distraídas observando o movimento na avenida. Detalhes que me encheram os olhos. Desenho feito com caneta nanquim preta.

Av. Beira Mar, em frente ao Palácio Anchieta, em Vitória-ES/Brasil. 
Figura 3: Um dia de muito sol

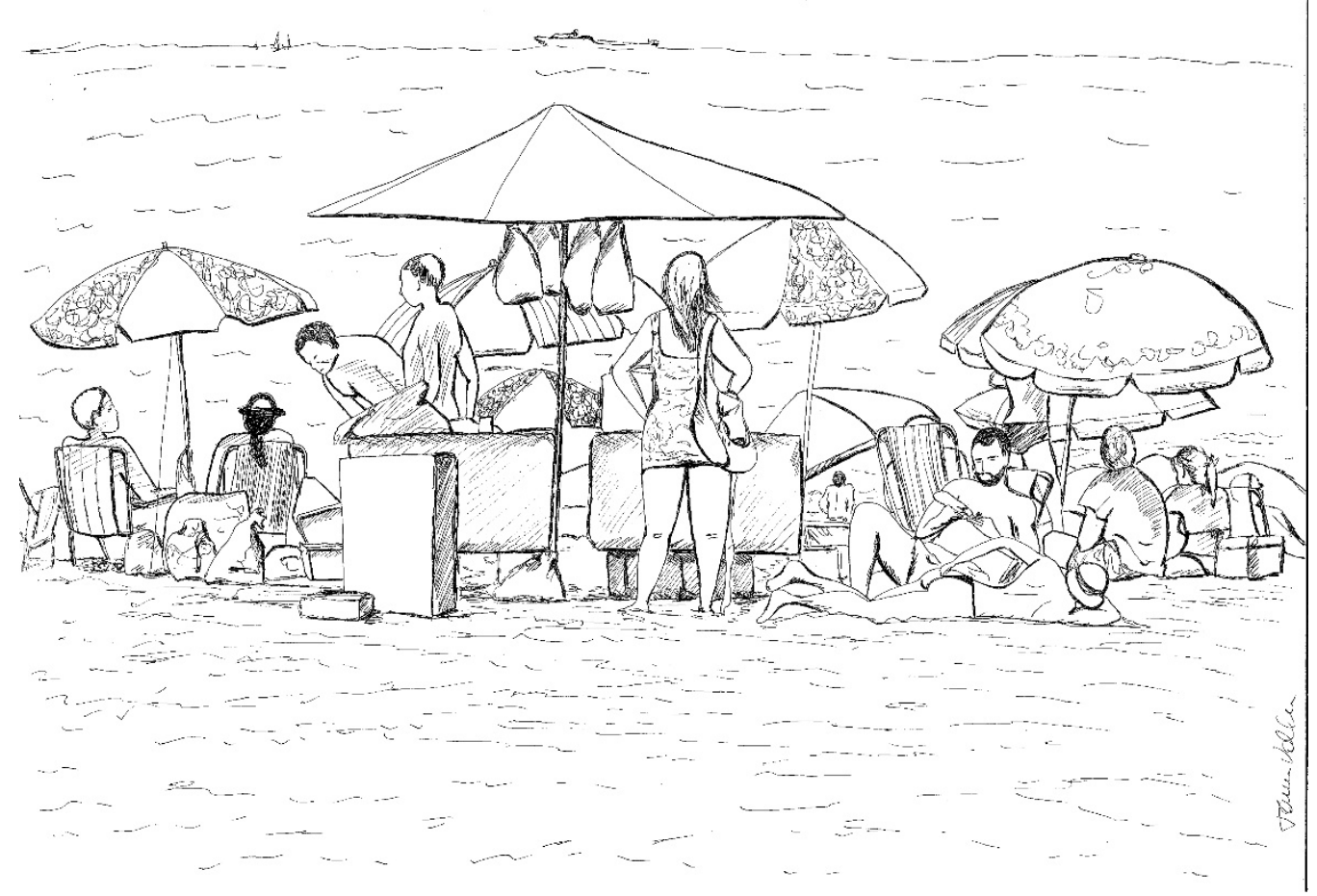

Neste dia, a praia estava cheia, guarda sol, pessoas felizes, trabalhadores retirando ali os seus sustentos num dia radiante de céu azul. Para este desenho eu utilizei caneta nanquim preta sobre o papel. Praia de Camburi em Vitória - ES/Brasil

Figura 4: As Paneleiras de Goiabeiras

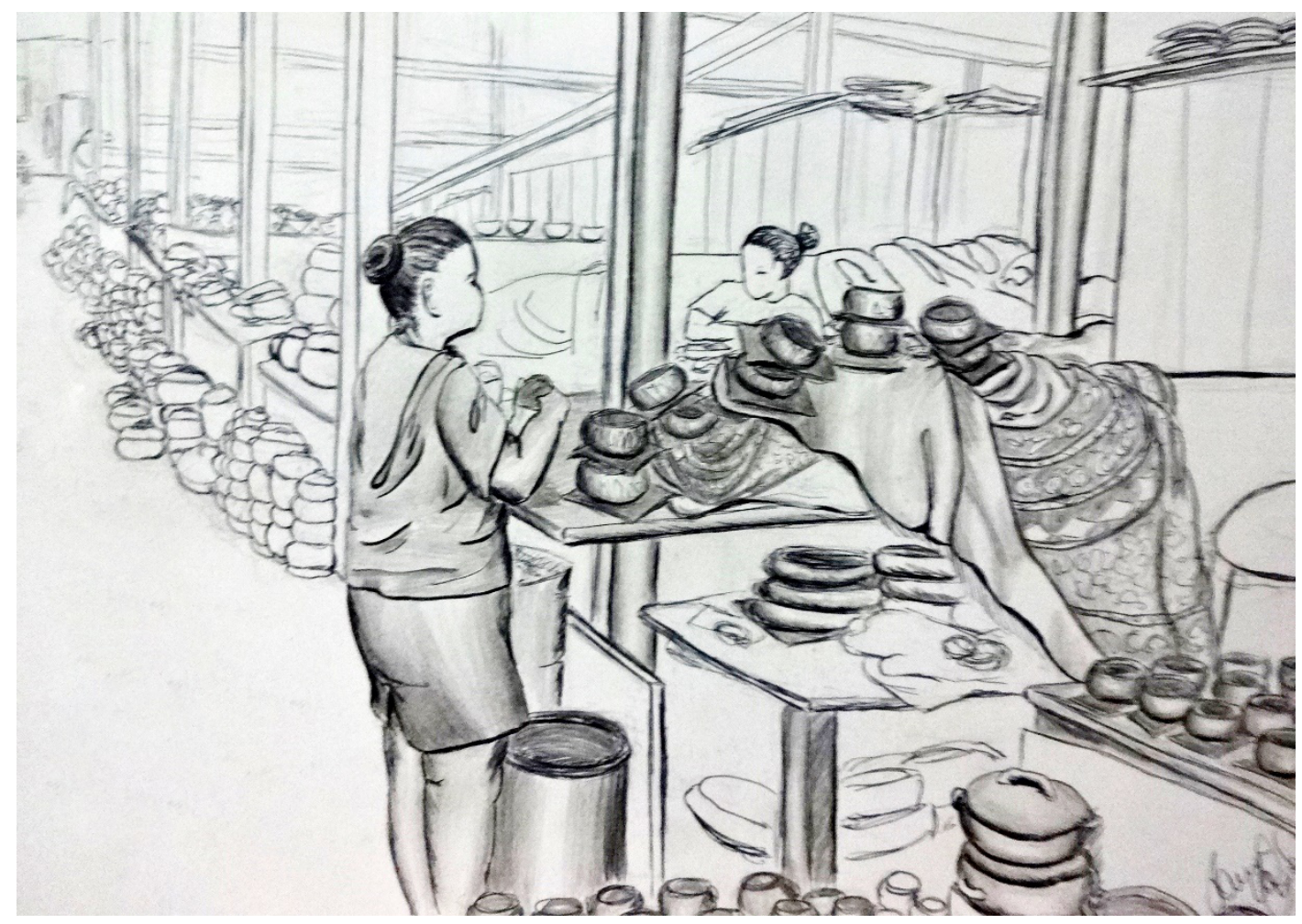


Um lugar que representa um dos ícones da cidade de Vitória, as panelas de barro e todo o processo de produção desta arte milenar capixaba. Fazer uma moqueca numa destas panelas, tem um diferencial muito grande. Inclusive, faço umas calabresas picadinhas deliciosas nestas panelas, sem por óleo algum, fica muito saborosas. Goiabeiras é o nome do bairro onde tudo começou e lá, elas continuam. Vitória-ES/Brasil

Figura 5: Uma Pausa, por favor

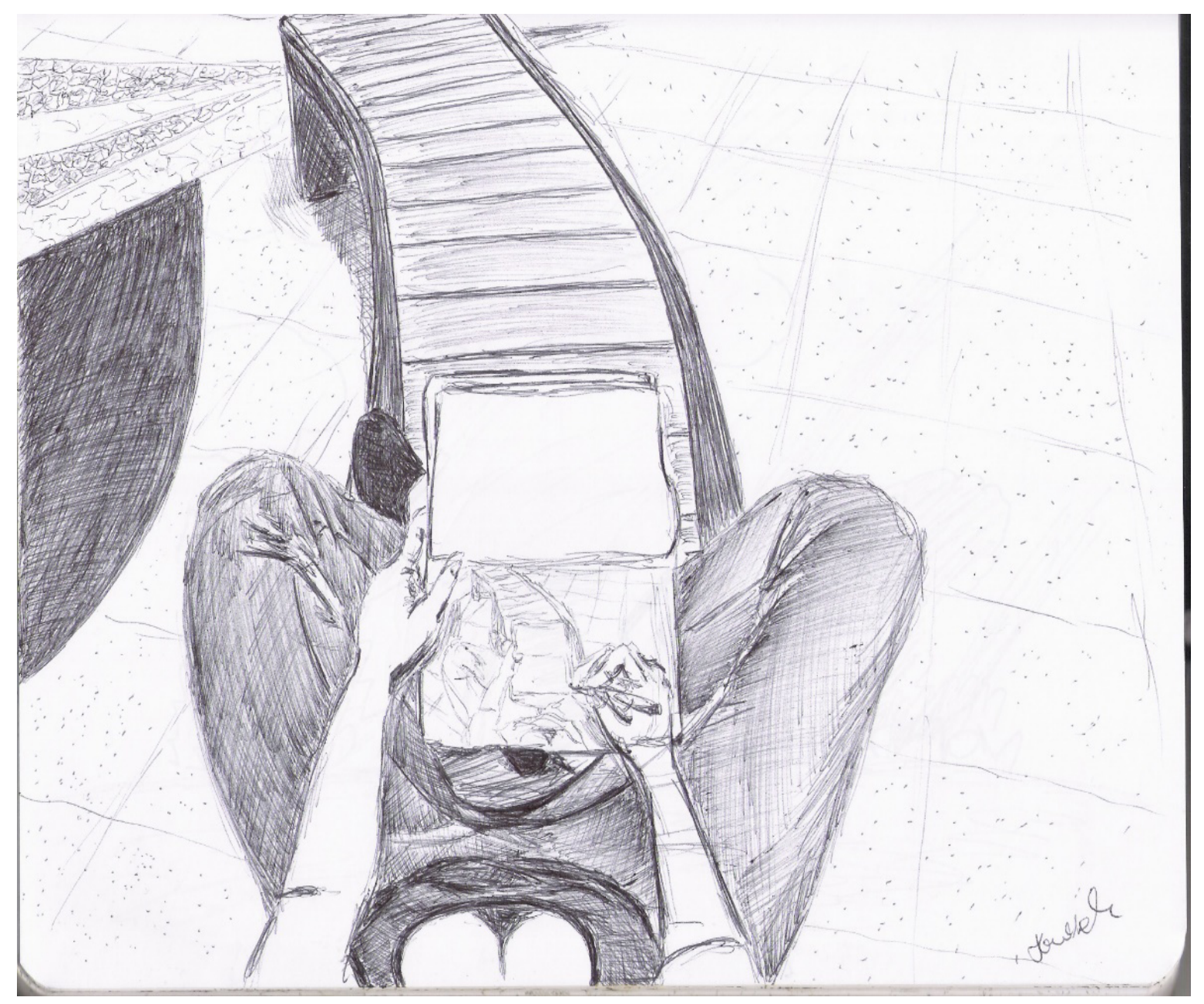

Uma paradinha no shopping, aguardando o meu filho chegar, desenhei a mim mesma, com caneta esferográfica preta. 
Figura 6:Crianças brincando

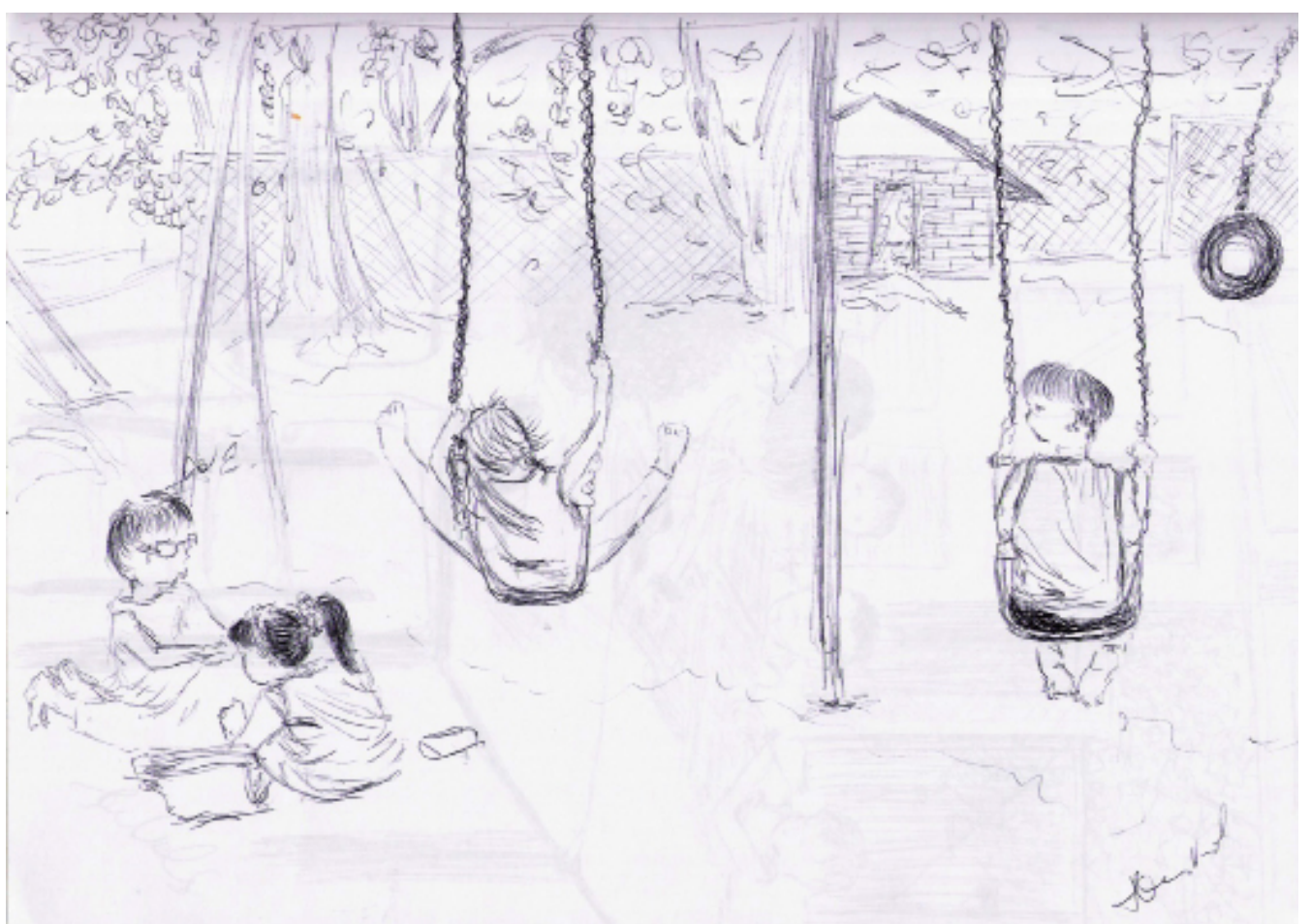

Esta foi uma das ilustrações que mais gostei de fazer, pois, as crianças estavam em movimento e isto foi encantador. Utilizei caneta esferográfica preta sobre o papel. Esta ilustração foi feita numa escolinha em Vitória-ES/Brasil

Figura 7: Um homem na barraquinha da praia

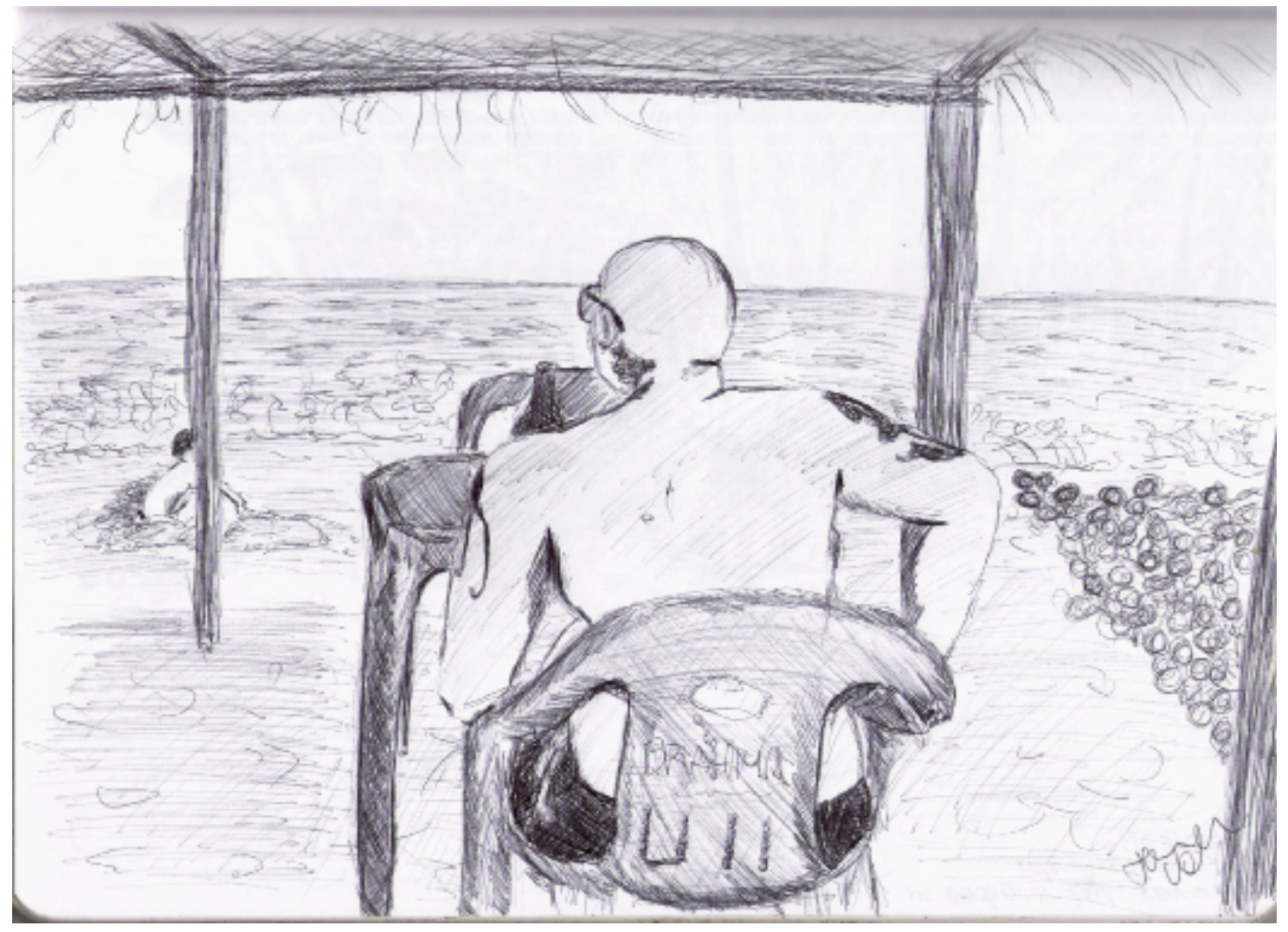


Achei muito interessante o que eu via, o homem tomava a sua cerveja, de frente para o mar e, cuidadosamente, observava o seu filho que brincava na areia. O dia estava radiante, o céu com um azul lindo, o mar calmo. Praia da Bocha em Coqueiral de Aracruz, Vitória-ES/Brasil.

Figura 8: O menino deitado no sofá

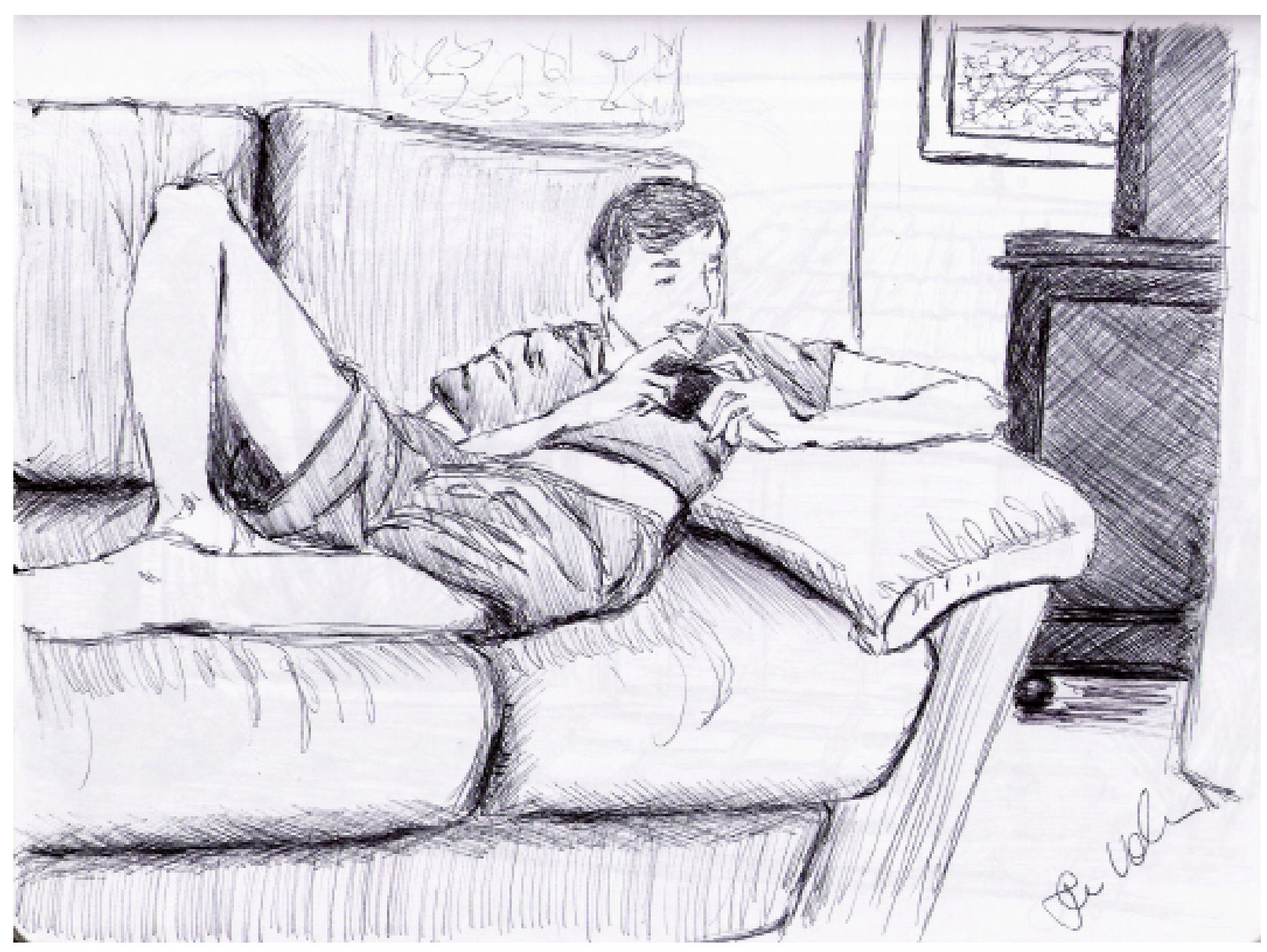

Eu fui dar um passei na casa de meu irmão e muito me chamou a atenção de meu sobrinho que estava deitado, distraidamente no sofá, brincando com um jogo no celular. Suas pernas compridas, as dobras do tecido de sua roupa, a posição dele esparramado no sofá e a perspectiva.

llustrei imediatamente o que os meus olhos registravam, precisei passar para o papel. Foi tão rápido que ele nem percebeu. Ilustração feita com caneta esferográfica. 
Figura 9: Numa cafeteria

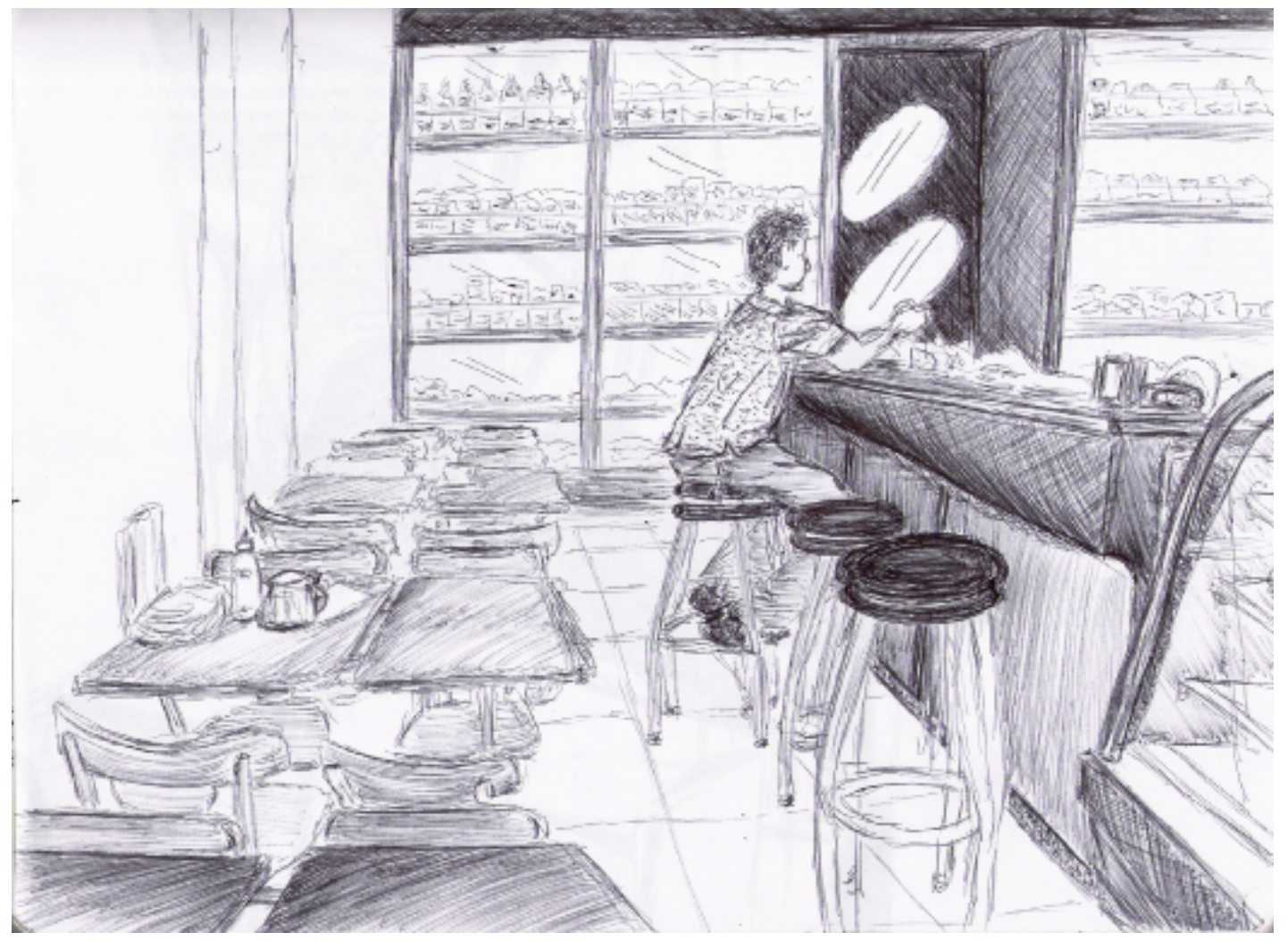

Parei para tomar um café numa cafeteria da cidade. A perspectiva do lugar me encantou e, logo, a transferi para o papel com caneta esferográfica azul.

Vitória-ES/Brasil

Figura 10: Capoeira

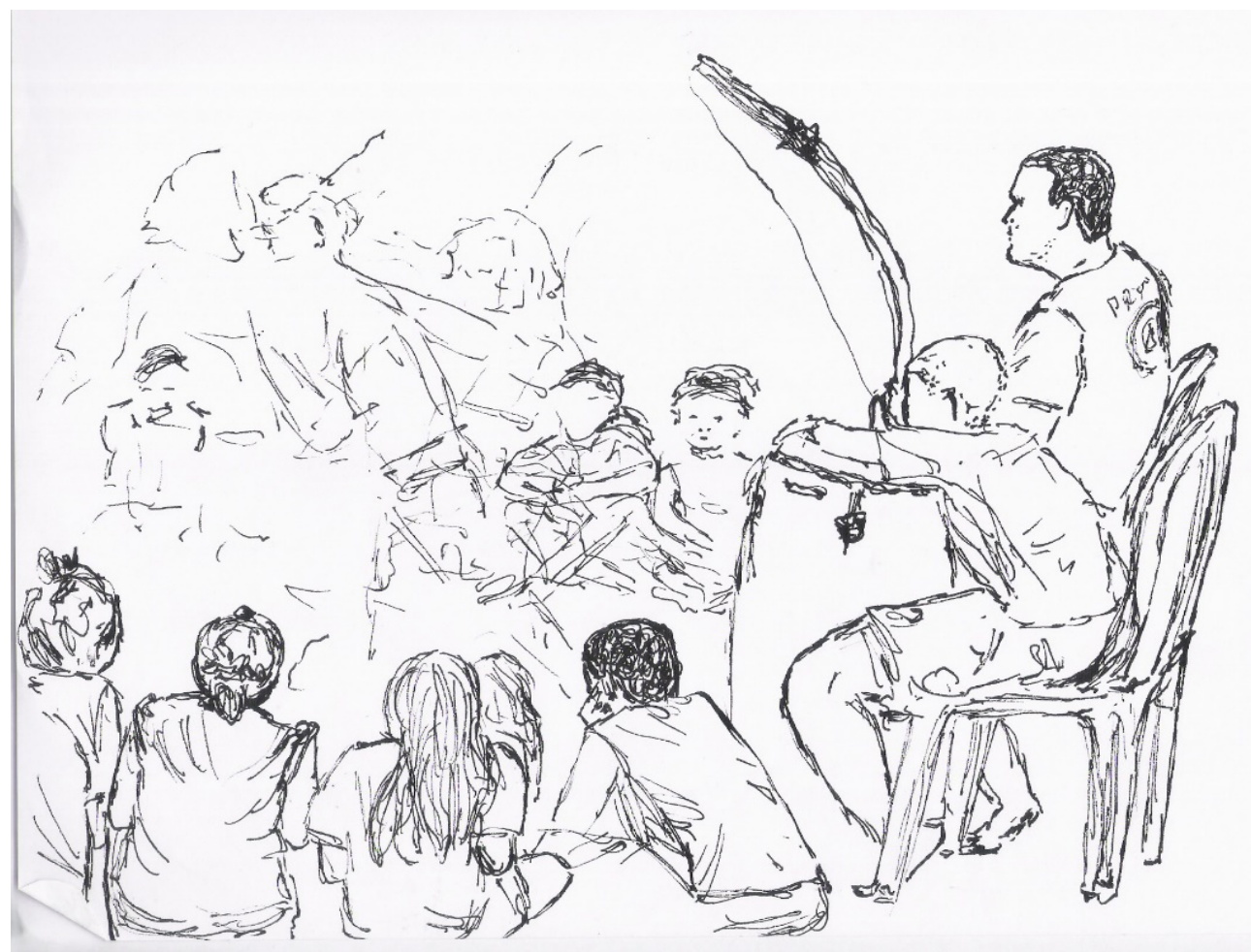


Os adolescentes de um grupo de capoeira, faziam uma roda, sentados e apreciando com muita atenção os movimentos da dança de capoeira que estava acontecendo no memento em que fiz este registro. É perceptível o movimento no centro da ilustração com caneta nanquim preta.

Vitória-ES/Brasil

Figura 11: Jovens na escola

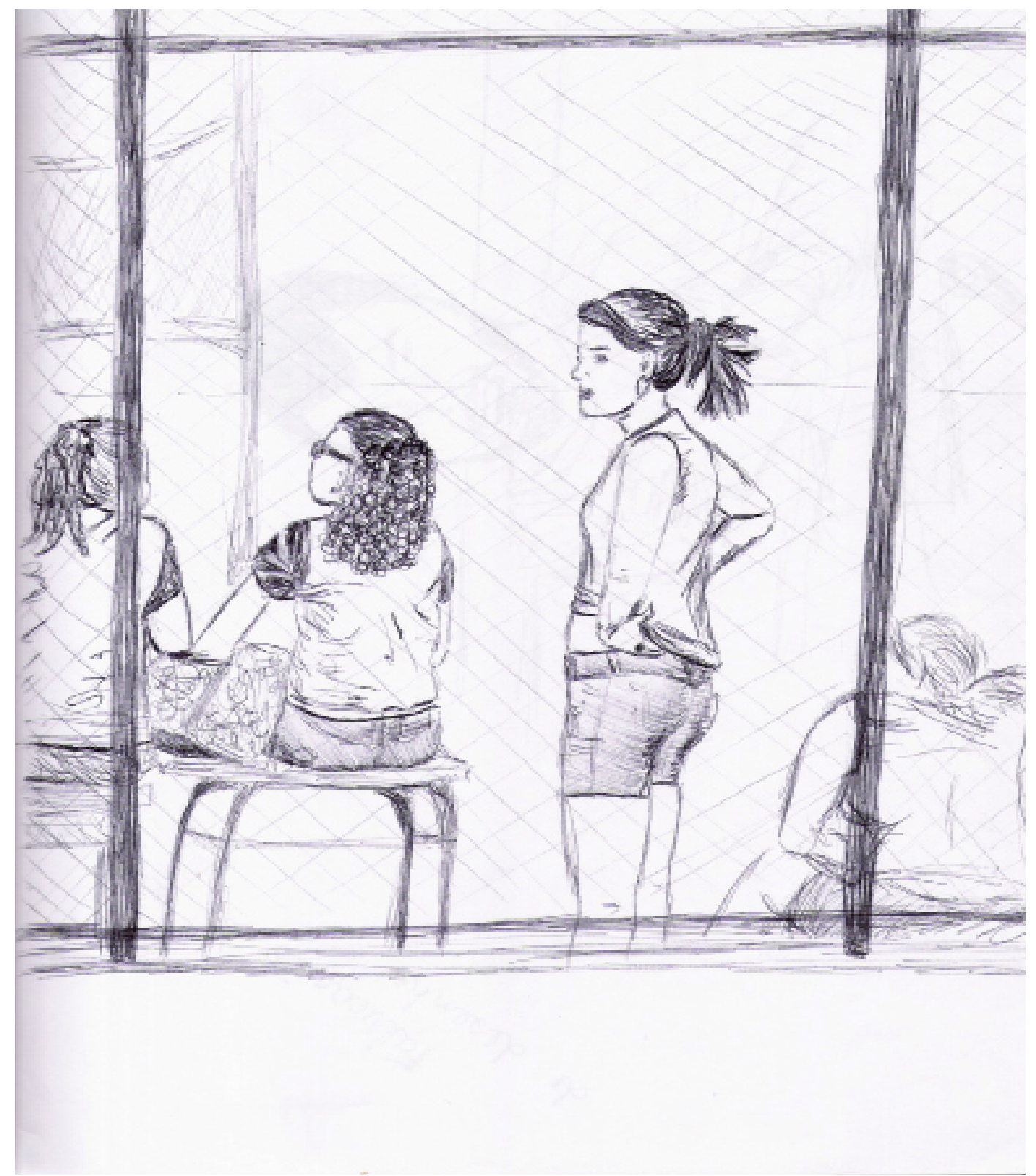

As meninas estavam na quadra de esporte participando de um evento e como eu estava passando pelo colégio e vi o movimento, tive que registrar, é claro. Ilustração realizada com caneta esferográfica preta.

Vitória-ES/Brasil 


\section{A PESQUISA EM ARQUEOLOGIA NO BRASIL OITOCENTISTA}

Dayse Marinho Martins ${ }^{3}$

3 Doutora em Políticas Públicas (UFMA), Doutoranda em História pelo Programa de Pós-Graduação em História e Conexões Atlânticas: culturas e poderes (PPGHIS-UFMA), Graduada em Pedagogia, História, Filosofia, Sociologia e Psicologia. Graduanda em Geografia. Professora SEMED SLZ e Especialista em Educação da SEDUC/MA, na Assessoria Pedagógica da Diretoria de Ensino e Pesquisa do Instituto de Educação, Ciência e Tecnologia do Maranhão (IEMA). Psicóloga CRP 22/03627. Docente externa permanente PPGPSI/ UFMA - Mestrado em Psicologia. Coordenadora do GT ANPUH MA Ensino de História e Educação E-mail: daysemarinho@yahoo.com.br. 


\section{INTRODUÇÃO}

As pesquisas científicas envolvendo elementos da cultura material visam inferir dinâmicas culturais, processos e normas que regem os universos sociais dos grupos que os produziram. Os estudos têm como objetivo, a reconstituição das culturas humanas. Através deles, o homem tenta compreender os vários segmentos de sociedades que viveram no mesmo espaço ocupado por ele atualmente.

Desta forma, ideias, comportamento e técnicas se materializam em objetos cujos contextos refletem padrões peculiares ao tempo, espaço e indivíduos responsáveis por sua configuração. Artefatos líticos, objetos cerâmicos, vestígios de habitações, ruínas, utensílios de uso doméstico ou ritualístico encontrados em um sítio arqueológico permitem identificar a "intenção" que motivou sua fabricação, seu conteúdo simbólico bem como a caracterização do grupo que o elaborou.

Grande parte das pesquisas em História do Brasil teve sua elaboração situada a partir de um viés historiográfico tradicional, isto é, tomando como ponto de partida a ocupação do território pelos europeus. Acabavam, portanto, desconsiderando os processos sociais desenvolvidos pelos nativos anteriormente à presença portuguesa em território brasileiro.

Nesse sentido, a pesquisa referente às práticas sociais dos nativos no período pré-colonial foi atribuída à Arqueologia. Esta se tornou responsável pelo estudo dos vestígios deixados por aqueles grupos sociais submetidos à lógica de dominação européia que os classificou como primitivos pela ausência da escrita e de desenvolvimento tecnológico.

No Brasil Imperial tratado neste trabalho, o estudo arqueológico se voltou para os sambaquis. Para tanto, fundamentou-se na lógica evolucionista relacionada à construção de uma identidade nacional para o brasileiro.

A dinâmica de elaboração destes estudos bem como os resultados e as interpretações etnográficas deles provenientes são o alvo deste texto. Nessa perspectiva, objetiva-se entender as teorias de cunho europeísta formuladas no Segundo Reinado sobre os primeiros povos do Brasil. 

OITOCENTISTA

No século XIX, destacou-se a tendência historiográfica rankeana. O expoente principal dessa corrente foi o alemão Leopold Von Ranke cujos fundamentos se baseavam na singularidade do fato histórico.

A História pode ser concebida como uma narrativa de fatos passados. Conhecer o passado dos homens é, por princípio, uma definição de História, e aos historiadores cabe escolher, por intermédio de uma variedade de documentos, os fatos mais importantes, ordená-los cronologicamente e narrá-los (BITTENCOURT, 2004 p. 140).

Como se pode perceber, nessa perspectiva de elaboração do discurso histórico, o passado era reconstruído em seus mínimos detalhes. "A reconstituição do passado da nação por intermédio de grandes personagens serviu como fundamento para a História" (BITTENCOURT, 2004 p. 141). Assim, os denominados "Estudos Sociais", detinham-se no estudo das ações políticas e militares de forma a instituir uma História da Nação por intermédio de uma narrativa.

Durante o século XX, a aproximação da História com novas Ciências Sociais, especialmente a Sociologia, Economia e Antropologia, culminou com uma renovação na forma de produção. Tal aspecto pode ser identificado com o surgimento da Escola dos Annalles que centrava suas análises iniciais nas mentalidades coletivas (CARDOSO, 1997).

A partir das décadas de 1970 e 1980 surgiram momentos importantes para a historiografia, posto que a reação ao paradigma de análise tradicional iniciada nestas décadas repercutiu decisivamente entre os estudiosos da disciplina. Este movimento propagado pelo desenvolvimento dos estudos no âmbito da Escola dos Annales francesa tornou-se conhecido como "Nova História".

O paradigma tradicional rankeano passou a ser criticado pelos adeptos da Nova História que congregaram uma diversidade de objetos entendendo toda e qualquer atividade humana como História. Centrado no campo político relativo às esferas do Estado Nacional, o viés historiográfico rankeano oferece um enfoque dos grandes homens e seus grandes feitos.

Por sua vez, os historiadores da Nova História, contrariamente, prestam-se à pesquisa de pessoas comuns e suas experiências para a mudança social. O para- 
digma rankeano preconizou o uso da documentação escrita, dos registros oficiais, negando com isso outras possibilidades de fontes. A utilização de tal diversidade é defendida pela Nova História, a partir da consideração das fontes orais, imagens, entre outros instrumentos.

Desde a descoberta do novo Mundo, os europeus buscaram entender o novo continente assim como seus habitantes considerando sua natureza exótica e até misteriosa. Percebe-se então a dificuldade em aceitar as diferenças principalmente culturais. Com isso, a estratégia mais prática para o conhecimento do ameríndio e da América constituiu a análise destes a partir da história europeia.

"São os descobridores que inauguram a História do Brasil e tudo que vem antes de sua chegada é pré-história." (BORGES, 2004 p.14). A atuação nativa foi compreendida, portanto, como diferente, pitoresca, sem existência própria ou dinâmica social, enfim, sem sua própria história.

O repasse destes estudos à Arqueologia ocorre mediante uma perspectiva tradicional e positivista de História que "trata por documento somente o escrito, deixando os vestígios materiais para outras Ciências" (BORGES, 2004 p.31). Atualmente, com a Escola dos Annalles e o apelo a uma Nova História, o cotidiano, a cultura, as mentalidades ganham novas dimensões e a História se aproxima da vivência humana tornando-se mais "a ciência dos homens no tempo". (BLOCH, 2001 p.55).

Por trás dos traços sensíveis da paisagem, dos utensílios ou das máquinas, por detrás dos documentos escritos aparentemente mais glaciais e das instituições mais aparentemente mais distanciadas dos que as elaboram, são exatamente os homens que a História pretende apreender (BLOCH, 2001 p.75).

Desse modo, a pesquisa histórica envolvendo sociedades pré-coloniais surge com a intenção de situar tais grupos humanos enquanto sujeitos ativos no fazer histórico do território brasileiro. A análise histórica dessas populações correlacionase diretamente com os estudos da Arqueologia demonstrando a necessária interdisciplinaridade na compreensão das ações humanas no processo de intervenção na realidade.

Ao contrário destas novas perspectivas, a pesquisa em Arqueologia tradicionalmente não buscou situar os povos pré-cabralinos enquanto sujeitos

\section{3}


históricos com elaborações culturais próprias. Centrada em modelos europeístas, vê-se a tendência à classificação dos nativos na esfera da primitividade em virtude do critério tecnológico.

No Período Imperial, as pesquisas em Arqueologia no Brasil não promoveram escavações num intervalo de 20 anos após os estudos de Peter Lund em Lagoa Santa entre os anos de 1830 e 1840. As iniciativas neste campo só ressurgiram em 1864 com o conde de La Hure em Santa Catarina. Com base nessas ações, os sambaquis se tornaram os focos de abordagem da Arqueologia brasileira durante o Império.

Desde o Segundo Reinado que os montes de conchas despertam interesse no Brasil. A intrigante origem dos sambaquis envolvia, além dos cientistas e naturalistas da época, o próprio imperador. A tônica central das discussões orbitava em torno da origem dos sambaquis, se eles seriam obras da natureza ou obras do homem (BORGES, 2004 p. 64).

Como se pode perceber surge subitamente o interesse em pesquisas envolvendo zonas sambaquieiras por parte do Imperador D. Pedro II que acompanhava pessoalmente algumas escavações. Os referidos vestígios se tornaram alvo de vários estudos principalmente no Sul e Sudeste do Brasil.

Os sambaquis são constituídos pelos acúmulos temporais de sedimentos, conchas e artefatos que formam colinas mostrando fatias sucessivas de assentamentos humanos e seus vestígios materiais e culturais. Nesse sentido, as zonas sambaquieiras retratam predominantemente ocupações em regiões litorâneas.

Os sítios mais antigos que conhecemos são construções edificadas com valvas de moluscos chamadas sambaquis. Aparecem entre 57.000 e 5.000 anos atrás, pelo menos e permanecem até 2.000 nos AP. seus autores eram caçadores e pescadores que também coletavam mariscos. Instalavam-se geralmente em baías entre vários ambiente complementares que forneciam alimentos específicos e recursos em água, madeiras e rochas diferentes." (PROUSS, 2006 p. 33).

Apesar das principais pesquisas enfocarem as regiões Sul e Sudeste do Brasil, os sambaquis também podem ser encontrados ao longo do litoral nordestino e não constituem aspectos distantes da realidade maranhense. $O$ intelectual maranhense Raimundo Lopes, foi quem localizou o primeiro sambaqui no litoral do Maranhão em 1919. Este foi encontrado no município de São José de Ribamar, próximo a São Luís (MARQUES, 1970).

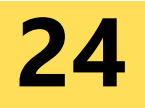


Os sambaquis do Pindaí e da Maiobinha por nós estudados ficam ambos no interior da llha do Maranhão. O da Maiobinha na zona das cabeceiras desse rio e a $8,5 \mathrm{Km}$ da costa livre, a $10 \mathrm{~km}$ do alcance da maré no vale do rio e a 3,5 $\mathrm{Km}$ da vila do Anil. O do Pindaí, no vale do Rio São João, tem características análogas; são, pois sambaquis mistos de superposição normal, de vestígios arqueológicos a antigo banco ou concha natural (LOPES, 1970 p. 22).

Apesar do pioneirismo de Raimundo Lopes na descoberta dos sambaquis maranhenses, as pesquisas sistemáticas só foram iniciadas por Mário Simões do Museu Paraense Emílio Goeldi na década de 70. Ao todo foram cadastradas 11 áreas de sambaquis sendo 8 na llha distribuídas entre São Luís, São José de Ribamar e Paço do Lumiar e 3 no município de Tutóia no interior do Estado. Os sítios encontramse destruídos pela ação do mar e exploração de cal, mas neles foi possível encontrar restos de cerâmica e artefato líticos além de três fósseis e vários objetos zoomorfos (LIMA, 1989).

Outro estudo de destaque no que se refere a esse tema pode ser encontrado na obra de PROUSS, 2007. Neste, o autor situa as populações em aldeias instaladas em encostas suaves e cursos d'água, caracterizando sítios a céu aberto com grandes concentrações de restos de cerâmica e conchas. Assinala ainda, a ocorrência de instrumentos de pedra lascada e restos alimentares. Sobre a tradição rupestre, o autor realiza uma descrição técnica ressaltando a submersão dos sítios durante as enchentes.

Na ocasião, Prouss faz referência aos ceramistas do Maranhão. Acerca destes, ele os situa em sítios preservados em lagoas pouco profundas com numerosos vestígios de cerâmicas e esculturas como os muirakitãs. $\mathrm{O}$ autor classifica esses sítios como vestígios da ligação entre o Nordeste e Amazônia e ressalta a importância de estudos para compreensão desse processo. No Maranhão, além das zonas sambaquieiras, esses sítios lacustres são conhecidos como estearias pela quantidade de esteios situados nos lagos indicando possíveis habitações.

Assim como os estudos de Raimundo Lopes no âmbito da arqueologia local, a obra de Prouss torna-se considerável ao abordar a constituição de sambaquis e estearias na região maranhense. Portanto, deve ser levada mais a sério na pesquisa arqueológica uma vez que tais sítios localizados na região dos Lagos na Baixada maranhense entre os municípios de Penalva e Viana só possuem similares em regiões da Suíça, mas nunca contaram com o desenvolvimento de pesquisas.

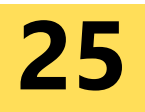


Apesar da insuficiência de pesquisas arqueológicas nos sambaquis maranhenses, os estudos envolvendo zonas sambaquieiras do litoral brasileiro possuem vasta literatura científica produzida a partir do Período Imperial. Mas, como explicar todo esse interesse por tais vestígios evidenciado no referido período da constituição histórica brasileira?

Segundo FUNARI (2005, p.135), os sambaquis foram "revolvidos pelo evolucionismo". Assim, as análises indicam que os estudiosos do Império nortearam suas pesquisas com base no referencial fornecido pelo evolucionismo na busca do entendimento da constituição das "raças" que formaram o Brasil.

Toda essa preocupação surge como pano de fundo na montagem de uma identidade nacional para o país caracterizado por traços multiétnicos. Na verdade constitui a estruturação ideológica de uma aliança entre a civilização representada pelo europeu e a antropofagia característica dos indígenas. Além de situar o traço identitário da população brasileira tratava-se de organizar uma espécie de política indigenista que situasse o papel do índio na sociedade imperial bem como na representação histórico-coletiva da nação.

A respeito do desenvolvimento das pesquisas destacam-se as iniciativas de Charles Wiener em Santa Catarina e de Domingos Soares Pena no Pará. Ambas tiveram seus relatórios publicados nos Arquivos do Museu Nacional. A pesquisa empreendida por Charles Wiener contou com o apoio do Museu Nacional na figura de seu diretor Ladislau Neto. "Ele explicou, como queria Ladislau Neto, a origem e a finalidade dos sambaquis." (FUNARI, 2005, p.135). Percebe-se neste ponto, o interesse do Império ao influenciar e ofertar suporte de uma instituição governamental à pesquisa de Wiener.

Os procedimentos adotados objetivaram contextualizar os sambaquis no espaço. Wiener acabou constatando que os sambaquis formavam ilhotas sólidas em meio aos mangues, afastados da costa.

Os vestígios dos sambaquis, portanto, registrariam, como informação etnográfica, a extensão da vitalidade do homem primitivo ante a influência impositiva da natureza, frente à contrição por ela exercida nos domínios físico, intelectual e social dos ancestrais indígenas. Afinal, os costumes humanos, nada mais são do que o comentário dessa lei de adaptação às premências da natureza (FUNARI, 2005, p.135). 
Como se pode verificar, o ponto em que o estudioso analisa a ação dos indígenas ilustra a relação destes com a natureza. A interpretação elaborada sobre os vestígios de sambaquis aponta a questão referente ao desenvolvimento tecnológico como forma de confrontar as dificuldades impostas pelo meio.

Wiener organiza seu estudo a partir da classificação dos sambaquis quanto à forma por meio do corte vertical e verificação de irregularidades (FUNARI, 2005). Nessa perspectiva, os sambaquis são classificados em três categorias: "os pouco extensos para servir de trincheiras; os irregulares em formato de colinas, apoiados em rochedos e, os sambaquis com regularidade um pouco mais definida." (FUNARI, 2005, p.137).

Além de situar os sambaquis quanto à forma, Wiener se dedicou ainda, à identificação dos materiais que os constituíam. O referido procedimento constatou a presença de vestígios ósseos, conchas, areia, cinza e carvão, entre outros. Diante disso, o pesquisador elaborou uma classificação também composta por três categorias:

Os sambaquis com camadas irregulares de carvão, cinza e areia, bem como aqueles divididos unicamente por estratos horizontais de carvão; a segunda comporta os sambaquis com 'túmulos'; a última categoria, os sambaquis que não têm divisão interior, blocos inteiriços de conchas e sedimentos (FUNARI, 2005, p.135).

Por fim, o referido pesquisador promoveu a descrição dos artefatos, quanto às propriedades, medidas, formas, modelos e funções. Este último critério poderia definir a aplicação do artefato no cotidiano das populações sambaquieiras, isto é, se era voltado para o uso prático, artístico ou simbólico (FUNARI, 2005).

As etapas da pesquisa de Wiener caracterizam um exercício classificatório baseado em mensurações e definições técnicas. Suas constatações servem de base para a elaboração de premissas sobre a etnografia fundada na relação entre a idade dos sambaquis e os costumes dos sambaquieiros.

Wiener determina inicialmente uma tríplice origem para os sambaquis:

Os naturais, constituídos geologicamente, massas compactas de sedimentos e conchas; sambaquis que seriam produtos da 'indolência humana', simultaneamente artificiais e naturais, resultado de ações geológicas e de homens primitivos que não removiam os restos de suas refeições, com formas variáveis e geometricamente irregulares; por último, os que seriam obras da 'paciência humana', monumentos unicamente artificiais, diques e trincheiras (FUNARI, 2005, p.138). 
O estudioso coloca a proveniência dos sambaquis como naturais e artificiais. E com isso, elabora suas interpretações etnográficas situando a ação humana a partir da relação com estes dois critérios. Wiener centra-se nos sambaquis de origem mista, isto é, natural e artificial, os quais são por ele denominados de "indolentes" e naqueles de origem artificial, caracterizados como "monumentos". Nos primeiros a análise demonstra a presença de ossadas humanas indicando antropofagia e, portanto, não regulação por leis sociais. Nos outros, ocorre ausência de vestígios antropofágicos, mas presença de túmulos pressupondo a existência de memória e culto aos mortos.

Diante de tais constatações, o pesquisador acredita que no mesmo território ocorria a existência de grupos em estágios evolutivos diferentes demonstrando que apesar da antropofagia, havia índios avançando para o processo de civilização. Daí a idéia de que os indígenas formariam uma raça dentro da linha evolutiva humana (PROUSS, 2006).

Mas, o que inicialmente foi caracterizado como uma espécie de engrandecimento da população nativa do território brasileiro logo é desconsiderado. Isto ocorre a partir do momento em que o pesquisador interpreta etnograficamente tal diferença comparando-a com a perspectiva de desenvolvimento europeu.

(...) as primeiras manifestações humanas no Velho e Novo Mundo, são de fato diferentes _ enquanto lá uma anarquia antropofágica foi substituída por alianças mais civilizadas, aqui elas conviveram; enquanto lá ferramentas lascadas refinaram-se pelo trabalho, aqui matérias-primas geologicamente propícias fizeram o homem galgar etapas tecnológico-evolutivas (FUNARI, 2005, p;135).

Nesse sentido, a transposição de uma etapa tecnológico-evolutiva no fabrico de ferramentas não caracteriza mérito dos primeiros grupos sociais integrantes do território brasileiro, mas sim, fruto da natureza: propícia ao desenvolvimento. Enquanto isso, os europeus refinavam suas ferramentas lutando com os entraves do ambiente, obtendo avanços tecnológicos pelo mérito de sua capacidade intelectual. Vê-se, portanto, a presença explícita dos pressupostos evolucionistas nas conclusões obtidas por Wiener, e, além disso, o pensamento europeísta do pesquisador.

As pesquisas de Wiener atuaram como ponto de partida do segundo estudo desenvolvido no período Imperial. Executada por Domingos Soares Pena, com base 
nas mesmas técnicas desenvolvidas pelo estudioso anterior, a pesquisa centrouse nos sambaquis do Norte, especificamente na região do Pará. Além de realizar avaliações questionadoras sobre as conclusões de Wiener, Pena alertou para o estado de conservação dos sambaquis ameaçados pela indústria da cal. As avaliações deste último estudioso indicam que no Sul e no Norte, os sambaquis foram produzidos pelos mesmos fatores geológicos e antrópicos. Porém, para o naturalista, as interpretações etnográficas elaboradas por Wiener possuíam algumas incorreções (PROUSS, 2003).

A principal delas caracteriza a afirmação de que inexistiam leis sociais entre os sambaquieiros antropófagos. De acordo com Pena, "eles comiam carne humana, mas somente em rituais específicos (...) a antropofagia não é anárquica, resulta de uma norma social, uma regra bélica" (FUNARI, 2005, p.140). Pena se contrapõe à Wiener ao esclarecer que a antropofagia não caracteriza a ausência de normas sociais, mas sim, a presença de um pressuposto ritualístico que constitui uma forma de regulação do meio social.

Com base no exposto, observa-se nos estudos desenvolvidos por ambos os pesquisadores durante o período Imperial, a necessidade de situar o indígena brasileiro na escala evolutiva humana, tomando como base a prática da antropofagia. Para tanto, ocorre a tentativa de elaboração de um lugar social para o indígena, considerando, todavia, uma classificação que tem o europeu como referência.

\section{CONCLUSÃO}

O suporte teórico para as interpretações das análises de Charles Wiener e Domingos Pena no âmbito da Arqueologia Imperial tomou como ponto de partida a antropofagia. Nesse sentido, objetivou a elaboração de discursos acerca da inserção do indígena na sociedade brasileira. Ao compreender a participação do silvícola na constituição histórica nacional, tentando sob a égide evolutiva entender suas relações com a antropofagia, os estudiosos buscavam a efetivação de uma aliança entre europeu civilizado e indígena antropofágico na constituição da identidade nacional.

A relação entre o antropofágico e o civilizado define a análise dos arqueólogos cujas pesquisas denotam elementos ligados à tentativa de elaboração do caráter da nacionalidade brasileira. Ao mesmo tempo, a análise das práticas antropofágicas por meio dos sambaquis pelos estudiosos do Império pode ser considerada uma tentati- 
va de melhor compreensão do indígena para seu aproveitamento como mão-de-obra pela inserção na economia nacional diante da inevitável necessidade de abolição da escravatura.

Desse modo, pode-se perceber que a Arqueologia imperial brasileira não se direcionou apenas ao aspecto investigativo da cultura material, e sim buscou identificar, classificar e posicionar o elemento indígena no cenário de interpretação da cultura nacional. Não constituiu apenas um arcabouço técnico e teórico referente à cultura material, mas um verdadeiro instrumento de elaboração ideológica pela relação entre discurso e poder.

\section{REFERÊNCIAS}

BITTENCOURT, Circe. Ensino de História. São Paulo: Cortez, 2004.

BLOCH, Marc. Apologia da História ou o Ofício do historiador. Rio de Janeiro: Jorge Zahar Editor, 2001.

BORGES, Jóina Freitas. A história negada: em busca de novos caminhos. Teresina: FUNDAPI, 2004.

CARDOSO, Ciro F. Domínios da História: ensaios de teoria e metodologia. 5.ed. Rio de Janeiro: Campus, 1997.

FUNARI, Pedro Paulo. Identidades, discurso e poder: estudos da Arqueologia contemporânea. 1. Ed. São Paulo: Annablume, 2005.

FUNARI, Pedro Paulo. Arqueologia. São Paulo: Contexto, 2003.

LIMA, Olavo Correia. Pré-história maranhense. São Luís: Gráfica escolar S/A, 1989.

LOPES, Raimundo. Uma região Tropical. Rio de Janeiro. Fon-Fon e Seleta, 1970.

MARQUES, César Augusto. Dicionário Histórico e Geográfico da Província do Maranhão. Rio de Janeiro: Fon-Fon e Seleta, 1970.

PROUSS, André. Arqueologia Brasileira. Brasília: UNB, 2003.

PROUSS, André. O Brasil antes dos Brasileiros: a pré-história do nosso país. Rio de Janeiro: Jorge Zahar Editor, 2006. 


\section{NOTAS SOBRE A PRODUÇÃO HISTORIOGRÁFICA EM TEMPOS DE PANDEMIA}

Bruno César Pereira ${ }^{4}$

Vania Vaz ${ }^{5}$

$4 \quad$ Graduado em História pela Universidade Estadual do Centro-Oeste do Paraná - UNICENTRO, Campus Irati. Atualmente é mestrando em História pela mesma Instituição de Ensino Superior com bolsa financiada pela Coordenação de Aperfeiçoamento de Pessoal de Nível Superior - CAPES. E-mail: bruno_08cesar@outlook.com

5 Graduada em História pela Universidade Estadual do Centro-Oeste do Paraná - UNICENTRO, Mestre em História pela Pontifícia Universidade Católica de São Paulo - PUC/SP e Doutora de em Desenvolvimento Sustentável pela Universidade de Brasília - UnB. Professora Colaboradora junto ao departamento de História da UNICENTRO, Campus de Irati. E-mail: vanivaz22@ hotmail.com 


\section{INTRODUÇÃO}

Nos últimos meses a pandemia gerada pelo COVID-19, provocada pelo novo corona vírus (SARS-COV-2), esteve no centro das discussões acadêmicas de diversas áreas do conhecimento. Nota-se, que a preocupação com as discussões que envolvem a pandemia, atingiu primeiramente áreas como as da Saúde, Ciências Biológicas e Engenharias, que tem realizado uma série de ações imediatas na busca da fabricação de equipamentos que auxiliem o tratamento, prevenção e produção de remédios e vacinas que possibilitem a contenção da doença.

A pandemia também trouxe implicações a outras áreas do conhecimento, como as Humanas e Sociais, que também tem produzido uma série de reflexões acerca dos impactos da pandemia seja para com a saúde, educação, trabalho e o cotidiano. Como salienta o pesquisador Michel Goulart da Silva "[...] essas áreas mantêm importância fundamental para analisar os processos e contradições que provocaram a pandemia" bem como tem problematizado os "[...] efeitos desta sobre a sociedade" (SILVA, 2020, p. 02-03).

Assim, partindo da contribuição das Humanas e Sociais para as discussões acerca dos impactos da pandemia na sociedade, neste artigo, buscaremos nos debruçar sobre as produções historiográficas que tem dado destaque as questões que envolvem a pandemia do novo corona vírus. Nos concentraremos especificamente nas propostas de dossiês que tem buscado construir reflexões que versem acerca de temas tradicionais dos estudos em História, como: saúde, doenças, pandemias e suas implicações em instituições e no cotidiano, as políticas de saúde e os contextos sócio-políticos sejam nas idades antiga, média ou contemporânea, entre outras temáticas.

Esta investigação, configura-se enquanto um estudo exploratório que visa realizar um mapeamento das colaborações de historiadores e historiadoras no que tange o momento atual marcado pela pandemia global. Este estudo, pode ser compreendido também enquanto um "estado da arte", a partir da perspectiva de Norma Ferreira (2002) e Sandro Minussi et. al (2018), que propõem este tipo de estudo enquanto uma investigação de cunho bibliográfico, que se objetiva em mapear e discutir as produções acadêmicas concentradas em um tema específico. 
Ademais, nossa proposta se fixará nas produções de historiadores (as) e de outros (as) pesquisadores (as) das humanidades e da saúde que publicaram especificamente em periódicos científicos de História.

Buscaremos salientar por meio deste estudo, que o papel das investigações em História encontra-se concentrados em preocupações com o tempo presente, ou seja, como o momento atual. E, neste momento, a pandemia global acabou por gerar uma preocupação e a necessidade de se discutir, rediscutir e revisitar temas tradicionais desta área do saber. Neste sentido, buscamos evidenciar que o papel do historiador se encontra ligado diretamente com seu contexto atual, o seu vivido.

\section{HISTÓRIA E HISTORIADORES EM TEMPOS DE PANDEMIA}

Ao longo desta seção, buscaremos destacar o papel do historiador e dos estudos historiográficos, sobretudo, no que tange a emergência da pandemia no tempo presente. Como destacamos na seção anterior, os/as historiadores/as nos últimos meses têm realizado uma série de reflexões pertinentes para o momento atual, isto possibilita leituras e releituras de temáticas tradicionais deste campo do saber, bem como, traz para o debate novas questões, sobretudo aquelas ligadas a seus respectivos contextos sociais, que, na atualidade, estão marcados pelo isolamento social, as políticas públicas (ou inexistência destas), entre outros temas.

Por muito tempo acreditou-se que as pesquisas em História se encontravam apenas restritos aos estudos sobre passados longínquos, sobre os grandes homens (reis, generais, líderes políticos e religiosos), guerras e sobre as antigas civilizações, sobretudo, acreditava-se que o objeto dos estudos historiográficos correspondia aquilo que já passou. Tal perspectiva pode ser observada no contexto atual enquanto uma meia verdade, pois, a História ao longo das últimas décadas incorporou a suas investigações campos de estudo, metodologias e teorias que a possibilitaram ampliar seu leque de possibilidades de pesquisas. Da mesma forma, não foram abandonados os estudos sobre passados longínquos, muito menos sobre as guerras ou sobre as antigas civilizações.

História Cultural, Nova História Cultural, História Social, História do Tempo Presente e História Pública, são algumas das novas correntes historiográficas que desde as décadas finais do século passado tem contribuído significativamente para 
a construção e renovação das investigações em História, seja no Brasil, como no mundo.

Contudo, algumas indagações nos dias de hoje cercam o fazer histográfico. Quais as contribuições de historiadores e historiadoras no atual momento da sociedade? Sobretudo, quais as contribuições da História em meio ao contexto da pandemia gerada pelo COVID-19? Partindo destas duas questões, buscaremos traçar algumas considerações.

Como salienta Silva (2020), a História, entre as outras ciências Humanas e Sociais, atualmente tem tido maiores dificuldades de encontrar seu lugar em meio à pandemia. Segundo o pesquisador isto se dá pois:

[...] fica para o historiador a questão de como pode efetivamente contribuir no processo de superação da pandemia, afinal os produtos de sua pesquisa não intervêm de forma direta para salvar vidas. Certamente não é possível encarar a História como uma ciência funcional, ou seja, que vai produzir objetos para uso imediato da população (SILVA, p. 03).

Todavia, mesmo não possuindo uma atuação direta no tratamento, prevenção ou cura da doença, os historiadores podem ficar encarregados da apresentação de soluções, de forma indireta, para alguns dos problemas os quais a sociedade enfrenta neste momento. Como por exemplo trazer para o debate atual as experiências passadas, as memórias sensíveis, bem como evidenciar os negacionismos de outros períodos frente as pandemias e epidemias.

Da mesma forma, como destaca Silva (2020), ficaria a cargo dos historiadores e historiadoras: auxiliar na compreensão de processos econômicos, políticos e sociais, passados ou ainda em andamento, que permitem analisar a realidade contemporânea ou mesmo as ações da sociedade e do Estado no combate à pandemia.

Da mesma forma, estes pesquisadores podem investigar as trajetórias das políticas públicas, as situações econômicas e as mobilizações de classes ou de outros segmentos sociais. Assim como, cabe aos estudos historiográficos as análises acerca dos impactos e dinâmicas sociais relacionados a outros surtos, epidemias e pandemias ao longo da História, que podem ajudar a compreender "[...] o papel contemporâneo de políticas como a de isolamento, os tratamentos de saúde ou a relação desses fatores com os problemas sociais construídos ao longo de décadas ou mesmo séculos" (SILVA, 2020, p 02). 
Entre outros pontos, as investigações em História permitem estudar as ações, a partir, talvez, de uma perspectiva da História Comparada, ou seja, realizar investigações sobre diferentes lugares e contextos históricos, as políticas de combate direto e indireto adotadas por parte dos Estados Nacionais, governos e poderes locais.

Assim, partindo das considerações de Silva (2020), observamos que o leque de estudos em História que contribuem significativamente, mesmo que de forma indireta, para a compreensão deste fenômeno na atualidade é amplo e rico em possibilidade de investigação.

Da mesma forma, uma série de outros/as pesquisadores/as, como Laura Chaparro (2020), Carlos Henrique Paiva e Luiz Antônio Teixeira6 (D’AVILA2020, s./p. ${ }^{7}$ ), tem destacado a importância das humanidades, sobretudo da História, no momento atual. Estes pesquisadores têm destacado que as ciências humanas também têm trabalhando duro na busca por uma melhor compreensão sobre o novo corona vírus e suas implicações na sociedade.

Como destaca Paiva (D'AVILA 2020, s./p.):

Hoje, inúmeros colegas, a partir de diferentes lugares institucionais, estão produzindo análises bastante importantes para melhor compreendermos o processo pelo qual estamos passando. O que nos parece claro, neste momento, é que há um lugar razoavelmente privilegiado para as análises em perspectiva histórica. Tal lugar vem de uma trajetória de crescente destaque para o papel dos historiadores nas análises do campo da saúde.

Partindo destas considerações, buscaremos evidenciar que nos últimos meses alguns periódicos científicos da área de História, no contexto brasileiro, têm voltado seus holofotes para o debate acerca das epidemias e pandemias em diferentes recortes espaciais e temporais a partir da abertura e publicação de dossiês quem compõem os números destas revistas. Buscamos compreender que a abertura destes dossiês corresponde a uma demanda, ou seja, uma necessidade de se discutir questões que permeiam o contexto social, político e econômico atual, que neste momento estão entrelaçadas as questões que envolvem a pandemia gerada pelo COVID-19.

$6 \quad$ Estes pesquisadores atualmente participam do Observatório História e Saúde, projeto vinculado a Fiocruz, que possui como objetivo "a abordagem histórica dos problemas de saúde contemporâneos" Atualmente o grupo realiza reflexões sobre a Covid-19, "[...] a partir da incorporação e mobilização de entidades biomédicas e seus aparatos, que são os medicamentos, as tecnologias, os dados e conceitos relativos ao enfrentamento da pandemia. Ver: D’AVILA 2020, s./p.

$7 \quad$ s./p. = sem página 
Revistas como Cadernos do Tempo Presente (UDESC), Hydra (UNIFESP) e Temporalidade (UFMG) publicaram nos meses de julho e setembro de 2020 respectivamente, dossiês que versam acerca dos temas saúde, doenças, políticas públicas, implicações no cotidiano, trabalho, ações por parte de governos locais e nacionais sobre epidemias e pandemias entre os séculos XIX e XXI no Brasil e no mundo.

O dossiê História da Saúde e suas relações com a Sociedade, organizado pelo conselho editorial da Revista Hydra visava, segundo o editorial, dar:

[...] atenção aos problemas que surgiram com a pandemia em que vivemos, propôs um dossiê que dialogasse a história da saúde e com a nossa sociedade de maneira ampla. Entendemos que o problema em questão pode e deve ser debatido entre diversas áreas, mesmo que em uma revista acadêmica de História (CONSELHO EDITORIAL, 2020, p. 05).

Nestedossiê,aRevistadestacouanecessidadedediálogo, dainterdisciplinaridade e conta com artigos de pesquisadores de todo país pertencentes a diferentes áreas como: arquitetura, direito, serviço social, saúde, além de historiadores/as. Seus estudos concentram-se diretamente no contexto brasileiro, variando os recortes espaciais e temporais.

Já a revista Cadernos do Tempo Presente, em seu dossiê Covid-19, Sociedades \& Tempo Presente, organizado pelo conselho editorial do periódico, destacou que seu dossiê:

[...] reúne contribuições de pesquisadores de diferentes lugares: da Argentina à Alemanha, da Espanha ao Oriente Médio, chegando ao Brasil, o dossiê contém reflexões de pesquisadores, eles mesmos testemunhas, sobre a história em movimento de uma tragédia mundial (CONSELHO EDITORIAL, 2020, p. 02).

Diferente do dossiê anterior, as reflexões deste concentram-se diretamente em questões que envolvema pandemia gerada pelo COVID-19, como: ainstrumentalização política da pandemia, a criação de um glossário da pandemia de COVID-19 a partir da língua alemã, as reações da comunidade internacional sobre a pandemia, entre outros temas. Da mesma forma, parte dos pesquisadores que compuseram as investigações deste dossiê tratam sobre as implicações da pandemia em diferentes países, seja na Europa como América, discutem seus respectivos contextos, neste sentido o dossiê traz diferentes perspectivas desta pandemia em diferentes espaços 
do globo.

Já o dossiê da Revista Temporalidades, História e ciência em tempos de pandemia: reflexões e perspectivas, organizado pela pesquisadora Vanessa Lana (2020), englobou, assim como o dossiê da Revista Hydra, diversos estudos e estudiosos que tratam sobre diversos recortes espaciais e temporais no contexto brasileiro.

A Proposta deste dossiê buscou reflexões sobre:

[...] os processos que conferiram protagonismo a determinados atores no presente, como os órgãos governamentais de saúde pública, a indústria farmacêutica, a Organização Mundial de Saúde, entre outros? Quais foram as rupturas e continuidades na legitimidade e no lugar ocupado pelas ciências perante as sociedades ao longo do tempo? Quem são os grupos historicamente mais afetados por problemas de saúde pública? De que forma as diferenças históricas entre o Norte Global e o Sul Global influenciam sua relação com a doença, a saúde e a cura? (CORPO EDITORIAL, 2020).

Lana (2020, p. 14), ao longo da apresentação deste dossiê, salientou que sua publicação:

[...] acompanha um contexto de transformações nas estruturas econômicas, sanitárias e políticas, marcado pelo rápido alastramento de uma pandemia que trouxe como um dos grandes desafios o de se pensar o papel da ciência e do negacionismo como chaves de respostas às demandas sociais.

Ao tratar especificamente sobre a produção histórica em tempos de pandemia, a pesquisadora salienta que as epidemias e pandemias devem ser compreendidas enquanto "[...] fenômenos biológicos e sociais que, assim como seus desdobramentos políticos, econômicos e culturais, acompanham a experiência humana em seus mais variados tempos e contextos históricos" (LENA, 2020, p. 15). Os artigos que compõem este dossiê apresentam uma enorme variedade de temáticas, fontes e perpassam discussões acerca de histórias conectadas e a circulação de saberes.

De modo geral, podemos observar que estes três dossiês, destacam a interdisciplinaridade do debate acerca da pandemia, contando como uma enorme variedade de estudos de pesquisadores de diferentes áreas (humanas, sociais, biológicas, saúde, etc.).

Bem como, como é destacado no final do editorial do periódico Cadernos do Tempo Presente: 
Em tempos de pandemia, os Cadernos do Tempo Presente se apresentam para colaborar no esforço de entender a tragédia. Vivemos tempos terríveis, sim. Os textos aqui contidos significam o esforço em oferecer interpretações, sugerir caminhos e, de alguma forma, poder nos ajudar para que a travessia por dias tão tristes seja um pouco menos dolorida (CONSELHO EDITORIAL, 2020, p. 02).

A proposta deste periódico, que também se aplica as produções expostas nos artigos da Revista Hydra e Temporalidades, evidenciam a preocupação com o momento atual, ou seja, destacam uma demanda que corresponde a uma necessidade de se discutir questões que permeiam o nosso contexto social, político e econômico. Da mesma forma estes estudos evidenciam que as questões que envolvem a pandemia transcendem as questões de saúde e doença, neste sentido, reforça-se a ideia de compreender as questões e dimensões geradas por tal acontecimento a partir de suas conexões sociais, econômicas e políticas.

Esta mesma preocupação pode ser observada a partir de outros dossiês que ainda não foram publicados. Como por exemplo os dossiês: História da Saúde e das Doenças: Instituições, Discursos e Relações de Poder (História Debates e Tendências - UFPR) e Pandemias na América Latina e no Caribe em Perspectiva Histórica e Global (Topoi - UFRJ), que serão publicadas no próximo ano (2021).

O dossiê proposto pela Revista História Debates e Tendências, organizado pelo pesquisador Éder Mendes de Paula, busca estudos que compreendam a complexidade dos conceitos de saúde e doença para além de "conceitos estanques", ou seja, buscam-se investigações que destaquem "a complexidade que envolve o estar são ou doente" e compreendam também que a "conceituação [saúde/doença] está envolvida nas relações de poder, nas disputas discursivas que dizem respeito aos diversos comportamentos referentes à multiplicidade de doenças existentes" (PAULA, 2020, s./p.).

Sua proposta não cita diretamente a pandemia, ou as implicações desta no cotidiano, na educação, no trabalho, etc. Contudo, ao fim da chamada, Paula (2020), destaca que a História da Saúde e das Doenças, ainda é "um campo a se fazer, possui um vasto terreno a ser explorado, trazendo ponderações importantes para a atual conjuntura em que vivemos" (PAULA, 2020, grifo nosso).

Se tratando do dossiê Pandemias na América Latina e no Caribe em Perspectiva Histórica e Global da Revista Topoi, organizado por Gilberto Hochman e 
Anne-Emanuelle Birn, a proposta busca por investigações que vão além dos temas médicos e científicos, buscam-se propostas que examinem os impactos sociais, econômicos, políticos e culturais das epidemias e pandemias na sociedade em diferentes temporalidades.

A proposta delimita algumas das questões que podem ser trabalhadas nos artigos:

[...] como e em que condições as sociedades consideram os problemas de doenças como epidemias/pandemias?; qual tem sido a interação entre as epidemias e o meio ambiente; como os contextos epidêmicos destacaram e exacerbaram raça/racismo e gênero/ patriarcado, entre outras fissuras?; e como os eventos transnacionais, a circulação de conhecimento e (des) informação e o intercâmbio de humanos e bens influenciaram as ideias e respostas domésticas? (HOCHMAN; BIRN, 2020, s./p.). ${ }^{8}$

Observa-se nesta proposta, o interesse por estudos que ofereçam discussões acerca da história das epidemias e pandemias no contexto da América Latina e no Caribe, mas também de suas interconexões com outras regiões do globo.

Mesmo que esta proposta de dossiê não realize nenhuma menção ao contexto atual, ou seja, a pandemia nesta segunda década do século $X X I$, reforçamos que os estudos em História na atualidade têm tido uma preocupação com temáticas como a saúde, doença, epidemias e pandemias, pois o atual momento evidenciou uma demanda para este tipo de discussão. Da mesma forma, o negacionismo, o descaso, enfraquecimento e descredibilidade do pensamento científico (sobretudo das humanas, sociais, bem como das ciências da saúde) são temáticas que se relacionam e se entrecruzam com o vivido dos pesquisadores na contemporaneidade.

Ao realizarmos a menção destes dossiês publicados, bem como aqueles que se encontram em fase a submissão de artigos, buscamos evidenciar que os estudos historiográficos na atualidade têm tido uma certa preocupação com o contexto social atual.

Buscamos neste mapeamento, evidenciar apenas os dossiês específicos da área de História, neste sentido salientamos que existem estudos historiográficos distribuídos em outras revistas cientificas (das áreas de História, Filosofia, Sociologia, entre outras) que versam sobre as temáticas da pandemia e seus desdobramentos. Da mesma forma as/os historiadoras/es têm publicado ensaios e livros que buscam 
debater as questões apresentadas até aqui.

Por exemplo, o livro Na saúde e na doença - História, crises e epidemias: reflexões da História Econômica na época da Covid-19, organizado por Rita de Cássia da Silva Almico, James William Goodwin Junior e Luiz Fernando Saraiva (2020) realizam uma importante investigação acerca das epidemias e pandemias globais em diferentes recortes históricos (da Idade Antiga ao século XX), destacando suas implicações sociais, econômicas e políticas ao redor do mundo.

Outro estudo que destacamos, é o livro Almanaque da Covid-19, de autoria de Valdei Araujo, Mateus Pereira e Mayra Marques (2020). Neste estudo, os pesquisadores têm o objetivo de compreender e explicar o atual momento, através de um misto de estilos de escrita (crônicas, diário e cronologia) a partir de uma mistura de vivências cotidianas e notícias do Brasil e do mundo.

Ambos os estudos reforçam as questões expostas até aqui, de que uma parte dos estudos historiográficos, sejam eles os artigos e ensaios publicados através dos dossiês (bem como aqueles espalhados em outras revistas cientificas), os livros, entrevistas, as lives realizadas por programas de pós-graduação ou por associações de historiadores (como é o caso da Associação Nacional de Professores de História - ANPUH), nestes últimos meses tem auxiliado a sociedade a entender os acontecimentos do presente em sua historicidade bem como reforçam o papel da História neste processo.

Em tempos sóbrios como este, seja pela pandemia bem como pelo negacionismo científico e histórico, as produções das Ciências Humanas e Sociais podem ser vistas enquanto raios de esperança na busca pela construção de dias melhores.

\section{ALGUMAS CONSIDERAÇÕES}

Ao intitularmos este último tópico de "algumas considerações" e não de "considerações finais", como é rotineiro em trabalhos acadêmicos, se deu, porque este estudo é deve ser entendido enquanto uma investigação exploratória, um breve "estado da arte". Talvez, poderíamos dizer que esta investigação corresponde a um breve mapeamento de algumas produções em História que tem evidenciado as questões acerca das pandemias e epidemias ao longo da história humana, bem como os seus impactos nos meios sociais, políticos e econômicos. 
Ao longo deste ensaio buscamos evidenciar que o papel dos estudos historiográficos produzidos, e, em produção, dos últimos meses, tem destacado temas de grande importância para o contexto atual, sobretudo a pandemia gerada pelo novo corona vírus e suam implicações.

Destacamos, que a pandemia e seus desdobramentos a nível nacional e internacional acabou por gerar uma preocupação por parte dos historiadores em produzir investigações que colocam em reflexão temas tradicionais desta área do saber, como saúde, doenças, pandemias, políticas públicas, entre outras temáticas.

Neste curto artigo, nos esforçamos em destacar que o papel do historiador e de periódicos científicos desta área, tem buscado disseminar investigações que se debruçam sobre as temáticas supracitadas, bem como, buscam problematizar seus impactos na sociedade, economia e na política. Buscamos reforçar aqui a proposta de Lena (2020, p. 15), que salienta que as epidemias e pandemias correspondem a fenômenos biológicos e sociais que acompanham a experiência humana em toda sua história, bem como, tais fenômenos possuem desdobramentos em diversas esferas da sociedade, seja a política, econômica e/ou a cultural. Partindo desta concepção tais fenômenos são passiveis de se tornarem objetos de estudo da História, pois como afirmou Jacques Le Goff: "as doenças têm História".

Acreditamos, que muitas investigações desta área do saber sobre, especificamente, a pandemia gerada pelo COVID-19 ainda estão por vir. Pois, para muito pesquisadores, os estudos em História não devem ser realizados no "calor do momento".

Contudo tal assertiva pode ser vista enquanto meia verdade, ou seja, aos historiadores não resta o estudo daquilo que já passou, que está encerrado, como bem observam as correntes historiográficas da História do Tempo Presente e História Pública.

Como salienta Silva (2020), mesmo que a História hoje tenha dificuldades em dar continuidade em suas produções, seja pela "impossibilidade de acesso às fontes, na medida em que os principais acervos - bibliotecas, museus, arquivos, entre outros - encontram-se fechados ou com acesso limitado", bem como pelo " uso de fontes orais limitados pela necessidade de quarentena em vigor, com suas diferentes fases de fechamento e flexibilização, [...]" o que acaba por dificultar "[...] o contato próximo 
entre as pessoas e, consequentemente, a realização de entrevistas." A produção historiográfica e de outras áreas das humanidades e sociais vem se reinventando através das novas tecnologias para a realização das entrevistas bem como para o acesso a acervos digitais.

Por fim, utilizando-se de uma citação de Reinhart Koselleck (2006), também utilizada brilhantemente por Silva (2020) no encerramento de seu estudo, salientamos que "[...] a história é a testemunha dos tempos, a luz da verdade, a vida da memória, a mensageira da velhice, por cuja voz nada é recomendado senão a imortalidade do orador" (KOSELLECK, 2006, p. 43, Apud SILVA, 2020, p. 05). Mesmo que não possa intervir diretamente no combate à doença ou na formulação de políticas públicas, resta aos historiadores e historiadoras a produção de reflexões que possam trazer luz aos processos, ações e contradições, afinal "é a tensão entre experiência e expectativa que, de uma forma sempre diferente, suscita novas soluções, fazendo surgir o tempo histórico" (KOSELLECK, 2006, p. 313 Apud SILVA, 2020, p. 05). Assim, como pudemos observar nesta breve investigação, tal papel vem sendo cumprido.

\section{REFERÊNCIAS}

ALMICO, Rita de Cássia da Silva; GOODWIN JUNIOR; James William; SARAIVA, Luiz Fernando. Na saúde e na doença - História, crises e epidemias: reflexões da História Econômica na época da Covid-19. Hucitec, 2020.

ARAUJO, Valdei; PEREIRA, Mateus; MARQUES, Mayara. Almanaque da COVID-19: 150 dias para não esquecer ou a história do encontro entre um presidente fake e um vírus real. Vitória: Milfontes, 2020.

CADERNOS DO TEMPO PRESENTE, Revista. Editorial. Revista Cadernos do Tempo Presente, v. 11, n. 01, 2020, p. 02. Disponível em: https://seer.ufs.br/index. php/tempo. Acesso em: 17 de out./2020.

CHAPARRO, Laura. A medicina não é suficiente: por que precisamos das ciências sociais para acabar com essa pandemia. Café História [online], 2020. Disponível em: https://www.cafehistoria.com.br/ciencias-sociais-novo-coronavirus-pandemia/. Acesso em: 19 de nov./2020.

D'AVILA, Cristiane. O uso da perspectiva histórica para analisar momentos de pandemia, segundo esses historiadores - Entrevista com Carlos Henrique Paiva e Luiz Antonio Teixeira. Café História [online], 2020. Disponível em: https://www.cafehistoria.com.br/historia-saude-publica-pandemia/. Acesso em: 19 de nov./2020. 
DOSSE, François. História do Tempo Presente e Historiografia. Tempo e Argumento, v. 4, n. 1, 2012, p. 05-22. Disponível em: http://dx.doi.org/10.5965/217518030401 2012005. Acesso em: 13 de nov./2020.

FERREIRA, Norma Sandra de Almeida. As pesquisas denominadas "estado da arte". Educação \& Sociedade. Campinas: v. 23, n. 79, p. 257-272, 2002. Disponível em: http://www.scielo.br/pdf/es/v23n79/10857.pdf. Acesso em: 19 de nov./2020.

HOCHMAN, Gilberto; BIRN Anne-Emanuelle. Pandemias na América Latina e no Caribe em Perspectiva Histórica e Global. Revista Topoi, v. 22, n. 48, 2020, s./p. Disponível em: http://revistatopoi.org/site/dossie-tematicol. Acesso em: 17 de out./2020.

HYDRA, Revista. Editorial. Revista Hydra, v. 04, n. 08, 2020, p. 05. Disponível em: https://periodicos.unifesp.br/index.php/hydra/article/view/11190. Acesso em: 17 de out./2020.

LANA, Vanessa. Apresentação: Ciência, História e Sociedades: múltiplas possibilidades. Revista Temporalidades, v. 12, n. 02, 2020, p. 14-19. Disponível em: https:// periodicos.ufmg.br/index.php/temporalidades/issue/view/1118. Acesso em: 17 de out./2020.

LE GOFF, Jacques (Org). As Doenças tem história. Lisboa: Terramar, 1985.

MINUSSI, Sandro Gindri; MOURA, Augusto Albuquerque; JARDIM, Mateus L. Gomes; RAVASIO, M. Homrich. Considerações sobre Estado da Arte, Levantamento Bibliográfico e Pesquisa Bibliográfica: relações e limites. Revista Gestão Universitária. v. 09, 2018. Disponível em: http://www.gestaouniversitaria.com.br/artigos-cientificos?volume id=17. Acessado em: 19 de nov./2020.

PAULA, Eder Mendes de. Chamada para Dossiê: História da Saúde e das Doenças: Instituições, Discursos e Relações de Poder. História: Debates e Tendências, v. 21, n. 01, 2020. Disponível em: http://seer.upf.br/index.php/rhdt/announcement. Acesso em: 17 de out./2020.

SILVA, Michel Goulart da. O Papel do historiador diante a pandemia. Boletim de Conjuntura, v. 03, n. 07, 2020, p. 01-05. Disponível em: http://doi.org/10.5281/zenodo.3885459. Acesso em: 17 de out./2020.

TEMPORALIDADES, Revista. Chamada de trabalho: Dossiê 33: História e ciência em tempos de pandemia: reflexões e perspectivas. Revista Temporalidades, v. 12, n. 02, 2020. Disponível em: https://periodicos.ufmg.br/index.php/temporalidades/announcement/view/237. Acesso em: 17 de out./2020. 


\title{
PRÁTICAS SOCIALIZADORAS E RELAÇÕES INTERGERACIONAIS: A CONTRIBUIÇÃO DOS AVÓS NA ESCOLARIZAÇÃO DE ESTUDANTES UNIVERSITÁ- RIOS
}

\author{
Tatiane Kelly Pinto de Carvalho ${ }^{9}$ \\ Elaine Gonçalo Bento ${ }^{10}$ \\ Denise Silva e Souza ${ }^{11}$ \\ Rosa Maria da Exaltação Coutrim ${ }^{12}$
}

$9 \quad$ Professora da Universidade do Estado de Minas Gerais (UEMG), Unidade Divinópolis. Coordenadora do curso de História na mesma instituição. Doutoranda em Educação (UFOP). Mestre em Educação (UEMG) e licenciada em História (UFMG). E-mail: tatiane.carvalho@uemg.br

10 Mestranda em Educação (UFOP). Bolsista CAPES. Licenciada em Pedagogia pela mesma Universidade. Pós-graduada em Ensino de Língua Portuguesa na Educação Básica no Instituto Federal Minas Gerais - Campus Ouro Preto (IFMG-OP). E-mail:elainebento2814@gmail.com.

11 Graduanda em História (UEMG). Bolsista PAPq (UEMG). E-mail: desilvasouza38@gmail. com

12 Professora associada do Departamento de Educação e da Pós Graduação em Educação da Universidade Federal de Ouro Preto (UFOP). Doutora em Ciências Humanas (UFMG) e Pós Doutora em Educação pelo Instituto Politécnico de Leiria- Portugal. E-mail: rosacoutrim@gmail.com. 


\section{INTRODUÇÃO}

Nas últimas décadas a Sociologia da Educação tem se debruçado sobre temáticas relacionadas às estratégias de escolarização dos indivíduos e os desafios inerentes a este processo. Como aponta Nogueira (2014, p.7) "tais investigações demonstram que uma trajetória escolar é fruto de uma combinação complexa de fatores (estruturais, familiares, pessoais) e que ela não se reduz a um único fator explicativo, nem a uma simples adição de fatores".

Considerando a afirmação de Nogueira (2014), pode-se constatar que para se discutir o processo de escolarização de jovens que alcançam a longevidade escolar é necessário reconhecer a influência da família e de demais grupos e indivíduos que interferem no processo de socialização e escolarização. No caso especifico da pesquisa apresentada neste artigo, a reflexão tira do foco o papel dos pais no processo de escolarização e se volta para outros importantes agentes familiares: Os avós.

A crescente inserção da mulher no mercado de trabalho, reforçando a necessidade de uma organização familiar com vistas a manter os cuidados das crianças, bem como o acompanhamento escolar, evidencia a necessidade de uma rede de apoio doméstica “...nesse caso, os avós (principalmente as avós) ocupam importante função na organização da casa e no cuidado das crianças em idade escolar" (COUTRIM et.al., 2007, p. 2).

Partindo da constatação de que tais transformações no âmbito familiar impactam os percursos escolares dos indivíduos, surgiu o desejo de compreender como a presença dos avós no cotidiano familiar influencia na educação dos netos. Assim, com a finalidade de contribuir para as reflexões na sociologia da educação sobre as trajetórias escolares de estudantes universitários criados ou cuidados por avós, suas práticas socializadoras e as relações intergeracionais, a pesquisa que originou este artigo se propõe a responder às seguintes questões: De que forma a herança cultural dos avós chega aos netos universitários dos meios populares? Por meio de quais processos educativos estes avós contribuíram para que os netos pudessem ingressar no ensino superior?

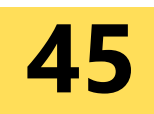


A partir de tais questionamentos, o objetivo central da pesquisa ${ }^{13}$, ainda em andamento, é compreender as práticas socializadoras empreendidas por avós na criação ou cuidados de netos, hoje universitários, pertencentes às camadas populares. Cabe ressaltar que os estudos sobre trajetórias escolares que abordam a relação entre as gerações mais próximas (pais e filhos) são mais comuns do que os que discutem o papel da terceira geração ascendente, ou seja, dos avós (COUTRIM, 2007). Pesquisas no Portal da Capes, no Google Acadêmico, repositórios de diversas universidades e em outras bases de dados nacionais revelam a escassez de investigações que se dediquem a compreender as trajetórias e mobilizações escolares dos estudantes de camadas populares criados ou cuidados por avós ${ }^{14}$.

Seguindo a abordagem qualitativa, o desenho metodológico foi construído a partir da pesquisa bibliográfica sobre a temática em questão e da aplicação de um questionário on line a todos os estudantes de diferentes cursos ingressantes na Universidade do Estado de Minas (UEMG - Divinópolis) no ano de 2020, buscando entre outros elementos, informações sobre o núcleo familiar (renda, moradia e convivência na família, ocupação e nível de escolaridade dos pais e avós) e participação dos avós na criação e/ou cuidados dos estudantes universitários.

\section{AS TRAJETÓRIAS ESCOLARES SOB O OLHAR DA SOCIOLOGIA DA EDUCAÇÃO: BREVES CONSIDERAÇÕES}

Diversos autores da sociologia da educação que discutem longevidade escolar consideram que a trajetória escolar é o resultado de uma combinação complexa de fatores (VIANA, 1998; PORTES, 2001; PIOTTO, 2008). Por isso, não se pode falar em longevidade escolar sem analisar o processo de socialização, que sofre influência das condições de existência, bem como das relações sociais e históricas estabe-

13 Este artigo é um recorte de uma pesquisa mais ampla, realizada no ano de 2020, intitulada "Trajetórias de estudantes universitários criados por avós: novas configurações familiares no século XXI", financiada pelo PAPq (UEMG), que buscou analisar as estratégias e mobilizações escolares dos estudantes universitários criados por avós, visando o ingresso no ensino superior. A pesquisa foi aprovada no Comitê de Ética e Pesquisa a UEMG e está registrada na Plataforma Brasil sob o CAAE: $n^{0}: 30600220.4 .0000 .5115$.

14 A análise da produção do conhecimento sobre as relações intergeracionais e os universitários criados ou cuidados por avós, disponíveis no Banco de Teses e Dissertações da Coordenação de Aperfeiçoamento de Pessoal de Nível Superior (CAPES) entre 2000 e 2020 (BRASIL 2020), mostra a necessidade de estudos sobre a temática. Site utilizado para a busca: http://bancodeteses.capes.gov.br. Acesso em: 23 de out. de 2020. 
lecidas entre grupos e indivíduos (THIN, 2006). Nesse aspecto, a discussão sobre as trajetórias escolares dos estudantes universitários está intimamente relacionada à reflexão sobre as disposições familiares, o processo de socialização e as práticas educativas familiares vivenciadas ao longo da infância e adolescência, que estão presentes no momento da escolha do curso superior. Quando escolhem seus cursos superiores os estudantes consideram suas chances de ingresso e de ascensão social, bem como avaliam as chances de sucesso futuro a partir da experiência escolar anterior (NOGUEIRA, 2005). Acrescenta-se que essa escolha ainda é pautada considerando as determinantes sociais (universidade pública e localização), bem como as mobilizações escolares empreendidas pelos estudantes para alcançar a educação superior, recordando que "entre a decisão de prestar o vestibular e o momento de inscrição há um longo caminho a ser percorrido, acompanhado de um grande investimento pessoal" (ZAGO, 2006, p. 230).

Nesse contexto o conceito de habitus auxilia na compreensão das trajetórias escolares longevas. O habitus, segundo Bourdieu (2010), é a matriz cultural que predispõe os indivíduos nos modos de pensar, agir e sentir sob a forma de disposições duráveis, incorporadas pelos indivíduos ao longo de seu processo de socialização. Influencia, dessa forma, na relevância que um indivíduo atribui à educação escolar, considerando as marcas de sua posição social, bem como dos símbolos, crenças e gostos que as caracterizam (SILVA, 2008, p. 95).

Contudo, o habitus, por si só, não explica os percursos e mobilizações escolares dos indivíduos; além das variáveis tradicionais já trazidas pelos estudos sociológicos $^{15}$, Lahire (2002) defende que é inviável pensar o indivíduo contemporâneo sendo regido apenas por um único princípio de conduta, isto é, o indivíduo não age de forma homogênea nas muitas situações de vida, coerente o tempo todo com um sistema de homogêneo de disposições. Na perspectiva do autor, mais do que buscar reduzir o conjunto das práticas e comportamentos de um indivíduo a uma improvável fórmula geradora, pode-se tentar reconstruir as disposições incorporadas ao longo da vida.

Ao lado do habitus, os capitais, principalmente o capital cultural, também devem ser levados em conta nos estudos das trajetórias escolares. Embora não ga-

15 Consideramos como variáveis tradicionais consideradas nos estudos sociológicos: renda, ocupação e escolaridade dos pais e a participação da família na escolarização dos mais jovens. 
ranta êxito nas trajetórias escolares, o capital cultural é capaz de exercer um efeito positivo sobre o rendimento escolar (ALVES et. al, 2013). Desse modo, os estudantes detentores desse capital, sairiam em posição de vantagem em seus percursos educacionais.

A junção do habitus, dos capitais e, consequentemente, as trajetórias escolares pregressas ao ingresso na universidade, orientam os estudantes no momento de escolha do curso e da instituição e ensino superior. Corroborando com Zago (2006) é possível afirmar que as chances de ingressar em uma instituição com forte concorrência no processo seletivo são muito maiores para aqueles que possuem uma formação pregressa de excelência. Portanto, analisar o processo de escolarização durante a educação básica é fundamental para os estudos de trajetória escolar dos universitários. A própria escolha do estabelecimento de ensino merece ser ponderada, como apontado por Resende et. al (2011, p. 956), pois varia “...em função do lugar que as estratégias de escolarização ocupam no conjunto das estratégias de reprodução da posição de um grupo".

Tais constatações demostram o distanciamento da ideia ainda hoje presente no senso comum de que a entrada na educação superior é resultado do mérito individual dos estudantes (NOGUEIRA e NOGUEIRA, 2015). O papel da história familiar e as estratégias e mobilizações anteriores à inserção no ensino superior (BOUDON, 1981) são elementos que a Sociologia da Educação enfatiza no percurso escolar, inclusive analisando-os nos planos macro e microssociais.

\section{AS RELAÇÕES INTERGERACIONAIS NA ATUALIDADE: A CONTRIBUIÇÃo dOS AVÓS NA EDUCAÇÃo FORMAL E NÃO FORMAL DOS NETOS}

Para a melhor compreensão da influência dos avós na trajetória escolar longeva dos estudantes universitários investigados são necessários alguns apontamentos a respeito das relações intergeracionais.

Por relacionamento intergeracional entende-se "a interação existente entre gerações diferentes" (SILVA, 2019, p 393). Nesse sentido, Schuler et. al (2019) afirmam que o relacionamento intergeracional pode provocar tanto uma aproximação geracional, bem como a presença de conflitos e tensões ocasionadas pela diferença 
de idades, de valores e crenças de cada geração. Cabe ainda ressaltar que a convivência entre as gerações de netos e avós contribui para inúmeras oportunidades de aprendizado (COUTRIM e SILVA, 2019).

Embora a avosidade não tenha relação direta com a velhice, uma vez que não é necessário ser idoso para ser avô ou avó, é importante considerar que nos últimos anos houve um aumento da expectativa de vida no Brasil, elevando o número de idosos no país (SCHULER et. al, 2019).

Apesar do acelerado envelhecimento da população brasileira e do consequente aumento do tempo de convivência intergeracional, ainda é escassa a produção bibliográfica sobre essa temática, principalmente quando se trata investigações sobre avós guardiões a partir do depoimento de netos adultos (COELHO e DIAS, 2016).

A literatura tem revelado (OLIVEIRA et. al, 2010; COUTRIM, 2006 e 2007; OSÓRIO et. al, 2018; CARDOSO, 2011; DIAS et. al, 2010; RAMOS, 2011) um empenho por parte dos avós em compartilhar com seus descendentes lições morais extraídas de suas próprias histórias de vida, procurando oferecer oportunidades, inclusive educacionais, cujos pais não podem disponibilizar à prole (COUTRIM et. al, 2007). Portanto, o convívio entre netos e avós implica em uma relação que envolve o suporte material, a socialização e a educação, uma vez que família pode ser considerada como a base de estratégias reprodutivas, matrimoniais, econômicas e educativas (BOURDIEU, 1997, p. 36). Os avós, então, têm ocupado papel central em muitas famílias, inclusive, passando a ter corresponsabilidade na criação e instrução dos netos. De acordo com Cardoso (2011, p. 23):

A valorização de comportamentos como a entrada da mulher no mercado de trabalho, a exacerbação da individualidade e o aumento da expectativa de vida alteram a dinâmica familiar propiciando que outras pessoas passem a fazer parte do cotidiano das famílias e desempenham atribuições relativas ao âmbito doméstico e ao cuidado com as crianças.

As dinâmicas familiares que incluem a participação dos avós na educação formal e não formal dos netos enfrentam limites e desafios. Os avós valorizam o estudo, porém sua participação efetiva nos deveres escolares dos netos é limitada. Os estudos de Coutrim e Silva (2019) demonstraram que a baixa escolaridade dos avós e a desatualização em relação aos conteúdos dos currículos escolares dificultam o apoio direto nos deveres de casa. Porém, esse quadro não exclui possibilidades de 
mobilizações dos avós no apoio ao processo de escolarização dos netos sob sua responsabilidade.

Pesquisas demonstram que eles buscam, por meio do capital social, que influencia na aquisição do capital econômico e cultural (BOURDIEU, 2010) construir estratégias que garantam a colaboração nas atividades escolares dos netos.

Com poucos anos de estudo e afastados por décadas dos bancos escolares, eles não assumem definitivamente a responsabilidade pela supervisão dos deveres escolares dos netos, mas encontram estratégias de apoio à sua escolaridade (COUTRIM; SILVA, 2019, p. 303).

Vale ainda pontuar que, apesar dos esforços na busca de estratégias que possam contribuir para o processo educativo dos netos, nem sempre as relações intergeracionais acontecem harmoniosamente. Coelho e Dias (2016, p. 5), remetendo-se ao trabalho de Edwards e Ray (2008), esclarecem que, para além das dificuldades oriundas da baixa escolarização, os avós também podem apresentar problemas relacionados à idade avançada e à saúde debilitada, o que limita seu apoio no processo educativo e de escolarização. Contudo, “...mesmo possuindo precária condição financeira, os avós não abandonam seus netos, o que evidencia a contribuição social dos mesmos e que ainda não é devidamente reconhecida" (ARAÚJO; DIAS, 2010, p. 236).

Mediante esses desafios e à complexidade no processo educacional que envolve as duas gerações, é fundamental reconhecer a necessidade de estudos que se debrucem sobre a análise da longevidade escolar de jovens universitários criados e/ ou cuidados por seus avós na infância trazendo maior foco para as mobilizações e estratégias educativas que contribuíram para a chegada ao ensino superior público.

\section{RESULTADOS E DISCUSSÃO: O QUE NOS REVELAM OS ACHADOS DA PESQUISA}

O questionário foi aplicado para, aproximadamente, 680 estudantes iniciantes, entre os meses de julho e agosto de 2020 por meio do Google Forms via internet, e foram obtidas 279 respostas. Todos os respondentes são ingressantes ${ }^{16}$ em diferen-

16 A aplicação considerou os cursos ofertados, sendo eles: Pedagogia, História, Psicologia, Engenharia da Computação, Educação Física (Licenciatura e Bacharelado), Engenharia Civil, Química, Serviço Social, Comunicação Social / Publicidade e Propaganda, Fisioterapia, Jornalismo, Letras, Enfermagem, Matemática, Ciências Biológicas. 
tes cursos da Universidade Estadual de Minas Gerais (UEMG) campus Divinópolis. O questionário foi dividido em duas seções: perfil socioeconômico dos discentes, escoIha do curso e da instituição de ensino; identificação dos alunos criados por avós e o nível de participação dos avós na educação dos netos ${ }^{17}$. Entre todos os respondentes, 26 disseram ter contado com a participação dos avós em sua criação, ou seja, $9,3 \%$ do total.

Em uma primeira leitura das respostas do questionário, o que chamou a atenção foi baixa escolaridade dos avós. A pesquisa mostrou que dos 119 alunos respondentes, 23 avôs (maternos e paternos) foram apresentados como analfabetos, outros 32 não chegaram a concluir o ensino fundamental, e os que possuem o ensino fundamental completo totalizam 13 indivíduos. Já em relação às avós maternas e paternas, notou-se um fato curioso. Nesta questão foram obtidas 138 respostas, 19 a mais do que a relativa aos avôs. Tal diferença sinaliza para o maior contato dos estudantes com as avós do que com os avôs. Assim como os avôs, também 23 avós foram apresentadas como analfabetas e o grupo mais representado se refere às que possuem o ensino fundamental incompleto (50 avós).

Como é possível observar, o nível de escolaridade dos avós é baixo, o que, de certo modo, impacta na trajetória escolar dos netos que por eles foram cuidados ou criados. Conforme constatado pelos autores apresentados neste artigo, esse é um fator que pode impedir ou dificultar o apoio dos avós aos seus netos quando o assunto são as tarefas escolares. Em alguns casos, como demonstra Cardoso (2011) em seu estudo com avós de classe média, alguns preferem não auxiliar nos deveres enviados pela escola por entenderem que essa atividade é de responsabilidade dos pais. Vale ainda ressaltar, neste contexto, que se impossibilitados de ofertar essa ajuda, os avós acabam por solicita-la a outros familiares ou vizinhos. Revelando, dessa forma, certo capital social (COUTRIM et al, 2018).

O questionário aplicado buscou ainda entender o apoio dado pelos avós aos respondentes no que diz respeito à contribuição nos deveres escolares. Do total de 138 respondentes, apenas 16 afirmaram que receberam auxilio dos avós nos deve-

$17 \quad \mathrm{Na}$ análise dos questionários, nota-se que alguns estudantes, mesmo não tendo sido criados ou cuidados por avós, sentiram-se confortáveis para responder a algumas questões específicas, revelando o carinho, o respeito e a consideração que sentem pelos avós. Por esse motivo, o número de respostas dadas às questões da etapa específica sobre os respondentes que foram criados e/ou cuidados por avós se difere da amostra total de 26 (vinte e seis). 
res de casa enviados pela escola. Considerando ainda que as notas alcançadas pelos alunos compreendem uma das formas que os pais e/ou responsáveis encontram para acompanhar o desempenho escolar das crianças ou adolescentes, no caso dos avós cuidadores essa realidade não se mostra diferente. Mesmo com baixa escolaridade, segundo Coutrim et. al. (2007), os avós cuidadores são presentes na vida dos netos quando o assunto é educação formal, mesmo que a grande diferença geracional possa se tornar um obstáculo na comunicação e interação entre eles.

O questionário também buscou levantar informações sobre o incentivo dos avós no processo de escolarização dos netos. A pesquisa revelou que dos 141 respondentes, a grande maioria (98 estudantes, ou 70\%) afirma que foram incentivados pelos avós a continuar os estudos. Com base neste resultado, nota-se que é frequente o fato de os avós incentivarem os jovens a estudar, bem como relatou Almeida (2011) no estudo realizado em uma escola municipal de Ponta Grossa, no Paraná. Em sua pesquisa, a autora possibilitou o encontro entre avós e alunos, nos quais os convidados contavam sobre suas trajetórias e aconselhavam os alunos a respeitarem os mais velhos, bem como incentivavam a longevidade escolar visando à ascensão social.

Quando questionados sobre a ajuda financeira oferecida pelos avós para aquisição de bens e serviços relacionados à trajetória escolar, os estudantes universitários demonstraram que esse apoio foi relevante em suas vidas. Considerando os 134 respondentes, mais da metade (56\%) afirmou que recebiam algum apoio financeiro dos avós. Nesse sentido, podemos inferir que esse apoio contribuiu na garantia das condições materiais mínimas para a continuidade e sucesso nos estudos. Inclusive, ainda é possível dizer, corroborando com Coutrim et. al. (2018), que o apoio material (bens e serviços) ofertado aos netos está vinculado às dificuldades dos pais em oferecer aos filhos essa ajuda. Contudo, não se pode desconsiderar que esse apoio financeiro, em alguns casos, principalmente em relação aos avós que assumem integralmente a criação dos netos, pode interferir negativamente nas finanças dos avós (MAINETTI e WANDERBROOCKE, 2013).

Ainda considerando o suporte na trajetória escolar dos netos universitários, o questionário permitiu compreender o apoio dado pelos avós para a realização de cursos extracurriculares. Dentre os 134 estudantes que responderam a essa questão,

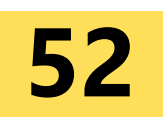


38 revelaram que receberam ajuda dos avós, mesmo que parcialmente. Um número bastante representativo ao se considerar que a grande maioria dos respondentes é de camadas populares ${ }^{18}$.

Na aquisição dos capitais, assim como descrito por Bourdieu (2010), frequentar espaços destinados ao lazer pode contribuir para a ampliação do capital cultural dos indivíduos. Como salienta Viana (2014), "as distinções escolares estariam sistematicamente associadas a desigualdades sociais, que são produzidas, sobretudo, pelas desigualdades de acesso ao capital cultural, repartido de maneira diversa entre os grupos da sociedade" (p. 24). Nesse sentido, possibilitar a presença dos netos nesses espaços influencia positivamente suas trajetórias escolares. Assim, os avós possibilitam, em muitos casos, esse tipo de experiência aos netos, inclusive como forma de oferecer aquilo que não propiciaram aos seus filhos (COUTRIM, 2006).

Com base em tal constatação, o questionário buscou também compreender se os avós proporcionavam aos estudantes atividades culturais como passeios em espaços como cinemas, teatros, eventos culturais, dentre outros. Dos 136 graduandos que responderam à questão, $12,5 \%$, ou seja, 17 sinalizaram que, parcialmente, os avós possibilitavam a presença deles nestas atividades. Esses achados demonstram que a baixa oferta de tais atividades culturais aos netos está estreitamente ligada ao perfil socioeconômico das famílias de camadas populares e com baixa escolarização, o que certamente influencia no baixo capital cultural e se torna uma barreira para que haja investimentos em bens culturais.

Por outro lado, o investimento dos avós aumenta quando se trata de capital escolar. Uma das perguntas destinadas aos estudantes universitários teve o intuito de indagar se os avós contribuíram financeiramente para a participação deles em cursos pré-vestibulares. Dos 134 respondentes, mais da metade (88 estudantes) não tiveram o apoio dos avós, 13 tiveram apoio parcial e 33 foram totalmente apoiados pelos avós. Ou seja, 34\% dos respondentes receberam algum auxílio financeiro dos avós para estudar. Este cenário demonstra que, apesar de pertencerem às camadas

18 Dos 279 respondentes, a maioria - 67,5\% (189 estudantes) declararam que a renda familiar mensal está entre entre 1 e 3 salários mínimos. Dessa forma, esses participantes fazem parte da classe D, pois segundo o IBGE (2016) a classe A compreende pessoas que têm um renda mensal acima de 20 salários mínimos, a classe B entre 10 a 20 salários mínimos, a C perpassa entre 4 a 10 salários mínimos, a D compreende de 2 a 4 salários mínimos, e por último a classe $\mathrm{E}$, que recebe até 2 salários mínimos.

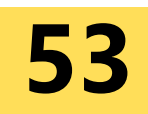


populares, um percentual significativo dos avós se esforça para contribuir financeiramente para a escolarização dos netos, pois, conforme já trazido pela literatura, as famílias de camadas populares valorizam a escola e investem na educação dos filhos e netos por acreditarem que a aquisição do diploma é o principal meio de ascensão social (COUTRIM et. al., 2018).

Além do apoio nas trajetórias escolares dos netos, nas pesquisas que tratam sobre as relações intergeracionais é comum perceber a afetividade entre avós e netos e, por isso, julgou-se importante trazer achados da pesquisa que contemplassem esses sentimentos. Como ainda salienta Saito e Loureiro (2013), esses avós que cuidam ou colaboram na criação dos netos acabam por absorver as responsabilidades que seriam dos pais. De uma forma ou de outra, eles se tornam fonte de segurança e influenciam na história de vida dos netos, principalmente as avós que ocupam papéis "voltados para educação e socialização dos netos" (CARDOSO e BRITO, 2014, p. 439).

Pautando-se nisso, o questionário indagou também se os alunos participantes do estudo tiveram contato com essas lições passadas pelos seus avós. Dos 145 respondentes, 123 (85\%) disseram que os avós Ihes transmitiam ensinamentos diversos, outros 16 demonstraram ter recebido tais ensinamentos e 6 participantes informaram não ter tido nenhum contato com essa educação moral ofertada pelas avós. Mediante tais resultados, é possível constatar que, independentemente dos conflitos geracionais e das dificuldades concretas relacionadas à renda e à escolaridade dos mais velhos, a relação entre os estudantes participantes da pesquisa e seus avós é próxima e constituída de apoio, aprendizado e solidariedade.

\section{NOTAS PROVISÓRIAS}

Com as modificações sofridas no papel desempenhado pelos avós nas últimas décadas, inclusive relacionadas à longevidade, aumentando o número de avós e quantidade de anos em que viverão (SAITO e LOUREIRO, 2013), investigar como eles têm contribuído para o processo de escolarização dos netos é um tema que merece ser explorado. Além disso, soma-se o que é posto por Cardoso (2011) de que com a maior convivência entre as gerações a colaboração dos avós no processo

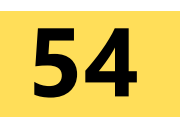


educativo dos netos pode se prolongar.

Os idosos cuidadores são um grupo ainda pouco conhecido enquanto agregador de valor à família e contribuinte para a construção de trajetórias escolares longevas dos netos. A pesquisa aqui apresentada demonstrou que, embora com baixo capital cultural e econômico, os avós auxiliaram na longevidade escolar dos netos. A herança que os mais novos carregam dos avós pôde ser observada sob diversas formas no estudo realizado: ensinamentos diversos, auxílio na realização dos deveres escolares, contribuição financeira para cursos extra escolares, etc. Os dados trazidos na pesquisa demonstram que essas contribuições tiveram impacto nos percursos pessoais e escolares dos netos e que, em diferentes graus, foram elementos relevantes para a construção de trajetórias escolares longevas dos mais jovens.

Diante dessas considerações, ressalta-se a necessidade de atenção aos diferentes fatores que constituem as relações entre avós e netos, incluindo as questões etárias, das gerações e a diversidade na vida social em geral (TEIXEIRA, 2003).

Conclui-se que a pesquisa realizada corrobora com estudos que demonstram que, cada vez mais, as relações intergeracionais vêm se estabelecendo nas famílias e que na fase adulta os netos reconhecem o papel dos avós em suas vidas. Certamente, discussões como as trazidas neste artigo são relevantes para os estudos sobre as relações intergeracionais na atualidade e a longevidade escolar, pois ainda são escassos os estudos que contemplem as relações intergeracionais no campo da educação. Por isso, as reflexões trazidas neste estudo sobre a participação dos avós no processo educativo dos netos são atuais e pertinentes ao momento vivido pelas famílias.

\section{REFERÊNCIAS}

ALMEIDA, Maria de Fátima Mello de. Hora da avó: encontro de gerações. Curitiba (PR): X Congresso Nacional de Educação - EDUCERE, Curitiba, 2011. Disponível em: https://educere.bruc.com.br/CD2011/pdf/5608_3619.pdf. Acesso em: 09 jan. 2020.

ALVES, Maria Tereza Gonzaga; NOGUEIRA, Maria Alice; NOGUEIRA, Cláudio Marques Martins; RESENDE, Tânia de Freitas. Fatores familiares e desempenho escolar: uma abordagem multidimensional. DADOS, Revista de Ciências Sociais, Rio de Janeiro, v. 56, n. 3, p. 571-603, 2013. 
ARAÚJO, Cristina Pinheiro de; DIAS, Cristina Maria de Souza Brito. Avós guardiões de baixa renda. Pesquisas e Práticas Psicossociais. São João del-Rei, v.4, n.2, p. 229-237, 2010.

BOUDON, Raymond. A desigualdade das oportunidades: a mobilidade social nas sociedades industriais. Brasília: Editora UnB, 1981.

BOURDIEU, Pierre. Os excluídos do interior. In: NOGUEIRA, Maria Alice; CATANI, Afrânio (Orgs.). Escritos de Educação: Pierre Bourdieu. Petrópolis- RJ: Vozes, $11^{a}$ ed., 2010. p. 217-227.

BOURDIEU, Pierre. Razões Práticas. Sobre a teoria da ação. Campinas: Papirus, 1997.

BRASIL. MEC/CAPES. Banco de Teses e Dissertações da Capes. Disponível em: http://bancodeteses.capes.gov.br. Acesso em: 03 fev.2020.

CARDOSO, Andréia Ribeiro; BRITO, Leila Maria Torraca de. Ser avó na família contemporânea: que jeito é esse? Pisco-os, Bragança Paulista, v. 19, n. 3, p. 433-441, set./dez. 2014.

CARDOSO, Andréia Ribeiro. Avós no século XXI: mutações e rearranjos na família contemporânea. Curitiba: Juruá, 2011.

COELHO, Maria Teresa Barros Falcão; DIAS, Cristina Maria Souza Brito. Avós Guardiões: Uma Revisão Sistemática de Literatura do Período de 2004 a 2014. Psicologia: Teoria e Pesquisa, v. 32, n. 4, p. 1-7, 2016. Disponível em: http://www.scielo.br/ pdf/ptp/v32n4/1806-3446-ptp-32-04-e324214.pdf. Acesso em: 09 jan. 2020

COUTRIM, Rosa Maria da Exaltação; SILVA, Pedro. Avós para cuidar ou para ensinar? Reflexões sobre a relação entre o tempo de cuidado e o grau de envolvimento dos avós na escolarização dos netos. In: RABINOVICH, Elaine Pedreira; MOREIRA, Lúcia Vaz de Campos; BRITO, Eliana Sales; FERREIRA, Marilaine Menezes (Orgs.). Envelhecimento e intergeracionalidade: olhares interdisciplinares. Curibiba: CRV, 2019. 295-306 p.

COUTRIM, Rosa Maria da Exaltação. Idosos trabalhadores: perdas e ganhos nas relações intergeracionais. Sociedade e Estado, Brasília, v. 21, n. 2, p. 367-390, maio/ ago. 2006.

COUTRIM, Rosa Maria da Exaltação; FIGUEIREDO, Adriana Maria de; JÚNIO, José Antônio de Oliveira; RESENDE, Armanda. O papel dos avós nos cuidados com a 
educação e saúde das crianças. Revista de Estudos Aplicados em Educação, v. 3, n. 5, p. 101-110, jan./jun. 2018.

COUTRIM, Rosa Maria da Exaltação; BOROTO, Ivonicléia Gonçalves. VIEIRA, Lívia Carolina; MAIA, lara de Oliveira. O que os Avôs ensinam aos Netos? A influência da Relação Intergeracional na Educação Formal e Informal. XIII Congresso Brasileiro de Sociologia, Recife, 2007.

DIAS, Cristina Maria de Souza Brito; HORA, Flávia Fernanda Araújo da; AGUIAR, Ana Gabriela de Souza. Jovens criados por avós e por um ou ambos os pais. Psicologia: Teoria e Prática, v.12, n. 2, 188-199, 2010.

EDWARDS, Oliver; RAY, Shannon. An attachment and school satisfaction framework for helping children raised by grandparents. School Psychology Quarterly, v.23, n.1, p.125-138, 2008. Disponível em : https://psycnet.apa.org/doi/10.1037/10453830.23.1.125. Acesso em: 20 ago. 2020.

IBGE. INSTITUTO BRASILEIRO DE GEOGRAFIA E ESTATÍSTICA. Síntese de indicadores sociais: uma análise das condições de vida da população brasileira 2016. Rio de Janeiro: IBGE, 2016. Disponível em : https://biblioteca.ibge.gov.br/visualizacao/livros/liv98965.pdf .Acesso em: 20 ago. 2020.

LAHIRE, Bernard. Homem Plural: os determinantes da ação. Petrópolis, RJ: Vozes, 2002.

MAINETTI, Ana Carolina; WANDERBROOCKE, Ana Cláudia Nunes de Souza. Avós que assumem a criação de Netos. Pensando Famílias, v.1. n.1, p.87-98,2013.

NOGUEIRA, Maria Alice. Prefácio. In: PIOTTO, Débora Cristina. (Org.) Camadas populares e universidades públicas: trajetórias e experiências escolares. São Carlos: Pedro \& João Editores, 2014. 273p.

NOGUEIRA, Cláudio Marques Martins; NOGUEIRA, Maria Alice. Os herdeiros: fundamentos para uma sociologia do ensino superior. Educ. Soc., Campinas, v. 36, n. 130, p. 47-62, jan./mar., 2015.

NOGUEIRA, Cláudio Marques Martins. Desafios teóricos na análise sociológica de um momento crucial das trajetórias escolares: a escolha do curso superior. In: ENCONTRO ANUAL DA ANPOCS, Caxambu: ANPOCS, 2005.

OLIVEIRA, Alessandra Ribeiro Ventura; VIANNA, Lucy Gomes; CÁRDENAS, Carmen Jansen de. Avosidade: Visões de avós e de seus netos no período da infância. Rev. Bras. Geriatr. Gerontol. Rio de Janeiro, v.13, n.3, p. 461-474, 2010. 
OSÓRIO, Neila Barbosa; NETO, Luiz Sinésio; SOUZA, Josafá Miranda de. A era dos avós contemporâneos na educação dos netos e relações familiares: um estudo de caso na Universidade da maturidade da Universidade Federal do Tocantins. Signos, Lajeado, ano 39, n. 1, p. 305-315, 2018.

PIOTTO, Débora Cristina. Trajetórias escolares prolongadas nas camadas populares. Cadernos de Pesquisa, v. 38, n. 135, p. 701 - 727, set/dez. 2008.

PORTES, Écio Antônio. Trajetórias escolares e vida acadêmica do estudante pobre da UFMG: um estudo a partir de cinco casos. 2001. 267f. Tese (Doutorado em Educação), Faculdade de Educação da Universidade Federal de Minas Gerais, 2001.

RAMOS, Anne Carolina. Meus avós e eu: as relações intergeracionais entre avós e netos na perspectiva das crianças. 2011.463f. Tese (Doutorado em Educação). Faculdade de Educação, Universidade Federal do Rio Grande do Sul, Porto Alegre, 2011.

RESENDE, Tânia de Freitas; NOGUEIRA, Claudio M. M.; NOGUEIRA, Maria Alice. Escolha do estabelecimento de ensino e perfis familiares: uma faceta a mais das desigualdades escolares. Educação \& Sociedade, Campinas, v. 32, n. 117, p. 953970, out./dez. 2011.

SAITO, Vera Lucia Espindola; LOUREIRO, Altair Macedo Lahud. O imaginário de um grupo de avós idosos responsáveis por seus netos adolescentes em vulnerabilidade. Revista Kairós Gerontologia, v.16, n.4, p.139-158. Dez. 2013.

SCHULER, Emily; COELHO, Maria Teresa Barros Falcão. CUNHA, Ubiracelma Carneiro da.; DIAS, Cristina Maria Souza Brito. Relacionamento intergeracional em diferentes contextos. In: RABINOVICH, Elaine Pedreira; MOREIRA, Lúcia Vaz de Campos; BRITO, Eliana Sales; FERREIRA, Marilaine Menezes (Orgs.). Envelhecimento e intergeracionalidade: olhares interdisciplinares. Curitiba: CRV, 2019. 417- 441 p.

SILVA, Cirlene Francisca Sales da. Relacionamento intergeracional entre idosos e adultos jovens: uma revisão sistemática (2008-2018). In: RABINOVICH, Elaine Pedreira; MOREIRA, Lúcia Vaz de Campos; BRITO, Eliana Sales; FERREIRA, Marilaine Menezes (Orgs.). Envelhecimento e intergeracionalidade: olhares interdisciplinares. Curibiba: CRV, 2019. 393-415 p.

SILVA, Maria Aparecida de Souza. A utilização do conceito de habitus em Pierre Bourdieu para a compreensão da formação docente. Revista Extra-Classe, n. 1, v. 2, p. 90-105, ago. 2008.

TEIXEIRA, Inês Assunção de Castro. Por entre planos, fios e tempos: a pesquisa em 
Sociologia da Educação. In: ZAGO, Nadir; CARVALHO, Marília Pinto de; VILELA, Rita Amélia Teixeira (Orgs.). Itinerários de pesquisa: perspectivas qualitativas em Sociologia da Educação. Rio de Janeiro: DP\&A, 2003. 81-105 p.

THIN, Daniel. Para uma análise das relações entre famílias populares e escola: confrontação entre lógicas socializadoras. Revista Brasileira de Educação, v. 11, n. 32, p. 211-225, maio/ago. 2006.

VIANA, Maria José Braga. Longevidade escolar em famílias de camadas populares: algumas condições de possibilidade.1998. 264f. Tese (Doutorado em Educação) - Faculdade de Educação da Universidade Federal de Minas Gerais, Belo Horizonte, 1998.

VIANA, Maria José Braga. Em que consiste a excelência escolar dos meios populares? O caso de universitários da UFMG que passaram pelo programa Bom Aluno de Belo Horizonte. In: PIOTTO, Débora Cristina. (Org.). Camadas populares e universidades públicas: trajetórias e experiências escolares. São Carlos: Pedro \& João Editores, 2014. 13-43 p.

ZAGO, Nadir. Do acesso à permanência no ensino superior: percursos de estudantes universitários de camadas populares. Revista Brasileira de Educação, v. 11, n. 32, p. 226-237, maio/ago. 2006. 


\section{A EDUCAÇÃO E O LIVRO DIDÁTICO A PARTIR DE UMA PERSPECTIVA HISTORICA: O CASO DAS REPRESENTAÇÖES FEMININAS}

Ary Albuquerque Cavalcanti Júnior ${ }^{19}$ Guilherme Nogueira M. Muzulon ${ }^{20}$

19 Doutor em História pelo Programa de Pós-Graduação em História (PPGH/UGFD). Docente do curso de Licenciatura em História da Universidade Federal do Mato Grosso do Sul, Campus Coxim (UFMS/CPCX); Membro do Laboratório de Estudos de Gênero, História e Interculturalidade ligado a Cátedra UNESCO (LEGHI/UFGD). Membro do Laboratório de ensino de História e Letras da Universidade Federal de Mato Grosso do Sul, Campus Coxim. Membro do grupo de estudos e pesquisa em História e Memória Geracional e Trajetórias Sociogeracionais (GHEMPE) sediado no Museu Pedagógico da Universidade Estadual do Sudoeste da Bahia e no Programa em Memória: Linguagem e Sociedade (PPPGMLS/ UESB). E-mail: academicoary@gmail.com

20 Mestre em História pelo Programa de Pós-Graduação em História (PPGH/UFGD). Docente da Rede Municipal de Educação de Dourados, Mato Grosso do Sul. E-mail: guilhermemuzulon@ gmail.com.br. 


\section{INTRODUÇÃO}

Em 2018, como alunos do Programa de Pós-Graduação em História da Universidade Federal da Grande Dourados (UFGD), nós começamos um diálogo sobre nossas pesquisas. Sinalizamos inquietações que perpassavam as representações carregadas pelos livros didáticos e os caminhos tortuosos que já naquele momento a educação brasileira enfrentava ${ }^{21}$.

Nossos debates apontaram para uma pergunta específica que resolvemos aprofundar, como as mulheres são representadas em livros didáticos de história?. Assim, permeando um diálogo entre nossas formações e pesquisas, que perpassam a história das mulheres e ditadura militar, e as diferentes representações dos movimentos sociais em livros didáticos, nos colocamos a responder o questionamento inicial.

Dessa forma, juntamos nossas inquietações e apontamentos, formulamos além da questão inicial, outras propostas de interesse comum: quais são as representações das mulheres que circulam nos didáticos de História? O que elas significam? Quais sentidos apresentam? O que elas nos contam e não contam?

Para respondermos tais questionamentos, evidenciamos que o livro didático e o livro didático de História têm sido analisados sob perspectivas diversificadas ao longo dos anos. Dentre elas, os pesquisadores definem livro didático como produto cultural (CHOPPIN, 2004), mercadoria (MUNAKATA, 1997; 2012; CASSIANO, 2007) e documento histórico (CHOPPIN, 2004).

Com isso, um dos nossos objetivos é o de explanar possibilidades de avanço e obstáculos limitadores da leitura interpretativa de representações que circulam com tais materiais. Eventualmente, esses entendimentos nos permitem conhecer o jogo de interesses entre os sujeitos históricos que fabricam as informações veiculadas, consumidas e ensinadas nos espaços públicos de ensino de História escolar (CASSIANO, 2007; MOREIRA, 2011).

A historiadora Célia Cristina de Figueiredo Cassiano (2007), em sua tese de doutorado, distinguiu as perspectivas que podemos ter sobre a materialidade e a

$21 \quad$ O presente artigo é uma versão atualizada do trabalho "O livro didático e a educação numa perspectiva histórica: o caso da representação das mulheres" apresentado e publicado nos Anais do IV Congresso de Educação da Grande Dourados ocorrido em 2018 na Universidade Federal da Grande Dourados (UFGD), Mato Grosso do Sul. 
funcionalidade dos livros didáticos, tratando tais perspectivas categorias analíticas. Para ela, o livro didático, enquanto documento histórico, é pesquisado pelos conteúdos que oferece, tais como um "tema, [...], uma noção, [...], um personagem, [...], uma disciplina, ou [...] como a literatura escolar foi apresentada por meio de uma literatura particular" (CASSIANO, 2007, p. 7).

Por outro lado, enquanto mercadoria, o livro didático, bem como o de história, devem ser entendidos como produtos físicos fabricados para serem vendidos (CASSIANO, 2007; MUNAKATA, 2012). Logo, a lógica da indústria cultural, inserida na sistemática capitalista, deve ser considerada. Em outras palavras, um livro didático de história que circula nas escolas públicas é, antes de ser manual pedagógico ou instrumento de estudos, um produto que gera lucro e que foi planejado para tal fim. A necessidade de gerar lucro embasa a qualidade técnica e informativa do material nos seus outros meios e usos. Portanto, causa impacto, também, nas representações forjadas para constar neles.

Dito isso, este artigo apresenta uma análise de representações de mulheres que destacamos a partir dos livros didáticos de história recentes de nosso acervo ${ }^{22}$. Contamos, também, para fins de levantar as hipóteses iniciais, com nossa experiência na docência.

Vale compreender, ainda, nosso entendimento sobre as representações. Trata-se de um instrumento analítico eficaz. Uma vez que, se por um lado, os livros didáticos de história são veiculadores de informações oficiais de ensino, por outro lado propagam representações de identidades construídas e autorizadas a serem ensinadas. Ou seja, tais materiais fomentam o desenvolvimento de saberes que moldam a consciência histórica ${ }^{23}$.

De maneira sucinta, sem a intenção de esgotar o debate, mas instrumentalizando nosso uso de representação como categoria analítica, o que são as representações sociais? Trata-se de um instrumento teórico metodológico de percepção da realidade social (MUZULON, 2019). Conforme o historiador Roger Chartier, as representações nos permitem "identificar o modo como em diferentes lugares e momentos 22 Em nossas pesquisas anteriores já temos trabalhado com todos os livros didáticos de História do Ensino Médio e do Ensino Fundamental - anos finais - inseridos no recorte temporal que compreende os editais do PNLD de 2008 até 2014.

23 Apresentamos nosso entendimento de consciência história neste trabalho: "(...) uma das expressões da existência humana, que não é necessariamente mediada por uma preparação teórica, por uma filosofia ou uma teoria da história complexamente elaboras" (CERRI, 2011, p. 95). 
uma determinada realidade social é construída, pensada, dada a ler" (CHARTIER, 1990, p. 17).

Para fins de ilustração e justificativa, evidenciamos que o resultado da análise das representações dos movimentos sociais tornou mais claro quais são os elementos significantes e construtores de sentidos que uma representação ou uma categoria de representações carrega em si (MUZULON, 2019).

Analisar representações também abre as janelas para buscar os agentes, no jogo de interesses, que disputam os sentidos que devem ser reproduzidos e os que devem ser ocultados. Neste sentido, é possível analisar as representações, buscando seus significados literais, alegóricos e conotativos, na perspectiva de que o livro didático é um produto fabricado para ser consumido. Onde as representações também o são, afinal de contas, as representações produzidas atendem às demandas de professores, alunos e da comunidade escolar.

Vale destacar que a busca e a análise de representações sociais ou "coletivas" possuem um procedimento intrinsecamente ligado ao cumprimento de objetivos específicos: (i) encontrar, nas práticas de sujeitos históricos e de suas relações de interesses, os motivos da criação das representações e de seus significados carregados; (ii) os meios pelos quais elas circulam, são veiculadas e apropriadas por outros sujeitos; (iii) a forma com que elas são reproduzidas e ressignificadas (CHARTIER, $2011)^{24}$.

Roger Chartier argumentou que o principal objetivo da história" é "identificar o modo como em diferentes lugares e momentos uma determinada realidade social é construída, pensada, dada a ler" (CHARTIER, 1990, p.17). Logo, Chartier não pensou o conceito de "representação" de forma isolada, como se este servisse apenas à História.

Em seu trabalho, juntou-se a outros dois conceitos fundamentais, que são o de "prática" e o de "apropriação". Segundo ele, todo historiador escreve sobre práticas (do passado). Elas dizem respeito às ações realizadas pelas pessoas. Já, a apropriação é o que ocorre quando um texto, uma imagem, um pensamento, uma ideia, uma obra, etc, é interpretada e quando o sujeito que a interpreta lida, ou atua em uma realidade distinta da qual ela foi produzida. Isto é, em outros lugares e contextos, por

$24 \quad$ Trata-se do método praticável para início de análise.

25 O autor se referiu especificamente à História cultural. 
outra pessoa, alguém diferente de quem produziu a informação.

Ainda para Chartier, não há "prática ou estrutura que não sejam produzidas pelas representações, contraditórias e em confronto, pelas quais os indivíduos e os grupos dão sentido ao mundo que é o deles" (CHARTIER, 1991, p. 177). Ou seja, concordamos com a noção de que a historiografia pretende representar um passado que existiu. Mas, aqui surge um problema. A representação corresponde, de fato, ao objeto representado? (CAPELLARI, 2006). O discurso, transmutado em texto escrito, traz à tona a realidade escrita? ${ }^{26}$. Chartier destaca que:

(...) representação coletiva autoriza a articular (...) três modalidades de relação com o mundo social: de início, o trabalho de classificação e de recorte que produz configurações intelectuais múltiplas pelas quais a realidade é contraditoriamente construída pelos diferentes grupos que compõem uma sociedade; em seguida, as práticas que visam a fazer reconhecer uma identidade social, a exibir uma maneira própria de ser no mundo, a significar simbolicamente um estatuto e uma posição; enfim, as formas institucionalizadas e objetivadas em virtudes das quais "representantes" (instâncias coletivas ou individuais singulares) marcam de modo visível e perpétuo a existência do grupo, da comunidade ou da classe (CHARTIER, 1991, p. 12).

Neste sentido, o modo como as mulheres são conceituadas condiz com as formas atuais de compreensão das mulheres? O conceito de mulher, a construção de personagens históricos, de sujeitos históricos, de indivíduos, do "ser mulher" obedece à qual lógica, baseia-se em qual princípio norteador ou em quais aparatos culturais? Quais os discursos que norteiam tais representações?

Ao respondermos tais perguntas, encontramos instrumento que aprimoram nossas leituras de mundo. Além do mais, perguntas semelhantes podem ser aplicadas em outros objetos de pesquisa historiográfica. Os livros didáticos de história, por sua vez, estão inseridos em uma longa trajetória da educação pública ${ }^{27}$ no Brasil. Essa trajetória é bem estudada, como podemos verificar, ao saber que esses livros já eram produzidos no século XIX, quando o país desenvolvia suas políticas nacionalistas, com o objetivo de fomentar a criação de uma identidade nacional unificada (ABUD, 1998).

26 Cf. LIMA, 2006, p. 268: “(...) aquilo que se impõe por si, o que, independendo da linguagem, está aí tanto para os homens quanto para os outros animais".

27 Não apenas nos sistemas públicos de ensino, mas também no ensino privado, como se pode verificar em CASSIANO, 2007. Neste caso, é nossa opção abordar apenas a trajetória do ensino público.

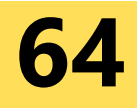


O governo republicano, no início do século XX, perpassando a Era Vargas e a Ditadura civil-militar, e atualmente, sempre se preocupou em regular, vigiar e avaliar livros escolares ${ }^{28}$. Notar esse fato já nos permite levantar a hipótese de que a manutenção de certas representações em LDHs torna-se instrumento de poder que merece atenção de sujeitos que disputam, de fato, o poder (FERRO, 1989; FOUCAULT, 2014).

Dessa forma, elegemos as representações das mulheres não apenas pela afinidade das pesquisas já produzidas, mas por acreditarmos se tratar de uma demanda da história da educação e da historiografia atual mais que necessária para se "romper" com visões distorcidas, as quais em sua maioria retiram ou silenciam as mulheres na História.

\section{A REPRESENTAÇÃo dA MULHER NO LIVRO DIDÁtico}

Nas últimas décadas uma série de avanços quanto a presença e a representação das mulheres em espaços por muito tempo negados passaram a ser veementemente combatidos. Combate este não apenas nos espaços de fala e/ou no campo ideológico, mas, também no campo das representações. Com isso, discursos que durante muito tempo silenciaram as mulheres historicamente começaram a ser revistos, propondo uma História das Mulheres. Como destaca Colling (2014).

Para uma história das mulheres, é necessário que a história geral passe a
ser entendida como resultado de interpretações, de representações, que têm
como fundo, relações de poder. Estas representações da mulher, atravessa-
ram os tempos e estabeleceram o pensamento simbólico da diferença entre
os sexos (COLLING, 2014, p. 13).

A partir do que elucida Colling (2014) ao nos remetermos para a educação em seu aspecto geral, é possível notar que existe uma grande importância das ações dos/ as educadores/as. Uma vez que contribuir para uma educação mais igualitária não apenas no sentido dos conteúdos, mas no âmbito do trabalho em combater visões excludentes sejam elas ligadas as relações de gênero, raciais etc. Mas, notamos que muitas vezes o ano letivo, bem como as dificuldades seja formativa do docente ou estrutural da escola, dentre outros fatores, não permitem o avanço em debates que busquem questionar discursos e representações já "perpetuadas". Partindo desse $28 \quad$ Há quatro tipos de livros escolares: (i) o livro didático; (ii) o paradidático; (iii) livros de referências; (iv) edições escolares clássicas (CHOPPIN apud MOREIRA, 2006, p. 11). 
pressuposto, o livro didático passa a ser uma espécie de guia de muitos docentes, criando com este uma linha conteudista, algo que muitas vezes não contempla muitos aspectos importantes na formação crítica dos estudantes.

Em se tratando de livro didático, como já dito anteriormente, ele leva em consideração não apenas os aspectos educacionais, mas, também os econômicos, haja vista a quantidade de editoras que surgem e/ou que já se encontram enraizadas no sistema de ensino brasileiro. Como define Circe Bittencourt (2004)

O livro didático é um importante veículo portador de um sistema de valores, de ideologia, de cultura. Várias pesquisas demonstram como textos e ilustrações de obras didáticas transmitem estereótipos e valores dos grupos dominantes, generalizando tema, como família, criança, etnia, de acordo com os preceitos da sociedade branca burguesa. (BITTENCOURT, 2004, p. 73).

Nessa perspectiva, ao analisarmos com cuidado, perceberemos o pouco, ou muitas vezes nenhum espaço destinado às mulheres nessas obras. Ao nos direcionarmos para a história, enquanto disciplina que a todo o momento dialoga com o passado, e para muitos alunos é a "representação" da verdade, observaremos um déficit muito grande nas representações que o livro didático traz aos professores e alunos acerca da presença e protagonismo feminino (CAVALCANTI JUNIOR, 2020).

Dessa forma, o que para muitas pessoas pode parecer nada significativo, um discurso vai se perpetuando e destacando a história dita "geral" e/ou "do Brasil" feita apenas por homens, ou seja, os detentores das façanhas. Dessa forma, as mulheres acabam sendo representadas de forma secundária, timidamente destacadas em casos isolados, a exemplos de Joana D'arc e no caso brasileiro de Maria Bonita. Esta última inclusive até hoje tem seu nome relacionado como "esposa" do temível Lampião. Mas, estudos como o de Negreiros (2018) destacam que essa visão atrelada ao de seu companheiro se deu principalmente pela indústria cultura, quando na realidade Maria Gomes de Oliveira empunhou armas e se posicionou em meio ao contexto histórico que vivia (NEGREIROS, 2018). Assim, como destaca Tedeschi (2012):

Incorporar a história das mulheres na produção do conhecimento histórico é um empreendimento relativamente novo e revelador de uma profunda transformação: está vinculado estreitamente à concepção de que as mulheres têm uma história e não são apenas destinadas à reprodução, que elas são agentes históricos e possuem uma historicidade das relações entre os sexos, relativa às ações cotidianas (TEDESCHI, 2012, p. 107). 
Dessa forma, o que se esquece muitas vezes é a importância das mulheres na história e no avanço da sociedade, tendo uma história própria e protagonistas no processo de sua construção.

A partir do exposto, o presente texto, cumprindo também a função de combater o esquecimento historiográfico acerca das mulheres, destaca nomes como Hipácia, pensadora, astrônoma e matemática da antiguidade, principalmente na cidade de Alexandria que foi morta acusada de bruxaria (FERNANDEZ; AMARAL; VIANA, 2019). Outro exemplo é o de Maria Quitéria de Jesus, primeira mulher a participar de uma unidade militar brasileira, onde lutou disfarçada no processo de independência da Bahia contra os portugueses (COELHO, 2019). O caso de Maria Quitéria, assim como de tantas outras mulheres, em seus variados tempos históricos, vivenciaram prerrogativas e discursos que normatizavam papéis femininos e masculinos, algo que poucos livros didáticos pontuam. Com isso, torna-se cada vez mais fundamental a inserção da discussão em torno das relações de gênero como categoria de análise histórica, como destaca Scott (1995).

Outro exemplo é o de Marie Curie, química e física polonesa, primeira mulher a ganhar um Prêmio Nobel. Durante muito tempo, assim como outras mulheres, foi impedida de cursar escolas, devido ao simples fato de ser uma mulher (MARTINS. 2003). O caso de Marie além de se assemelhar ao de muitas outras mulheres é importante notar que suas descobertas bem como menções a ela nos livros didáticos, seja de História ou de disciplinas afins, não ocorre. Com isso, notabilizamos, a partir desses exemplos, o pouco espaço destinado às mulheres nas obras didáticas. Haja vista que somos conhecedores de pensadores como Sócrates, Montesquieu, militares como Duque de Caxias, mas provavelmente muitas pessoas nem sabiam da existência das mulheres citadas anteriormente. Como destaca Colling (2014):

A história das mulheres é uma história recente, porque, desde que a História existe como disciplina científica, ou seja, desde o século XIX, o seu lugar dependeu das representações dos homens, que foram, por muito tempo, os únicos historiadores. Estes escreveram a história dos homens, apresentada como universal, e a história das mulheres desenvolveu-se a sua margem (COLLING, 2014, p. 21).

A partir do que nos expõe Colling (2014) e ao refletirmos sobre nossas vivências e análises dos livros, perceberemos o quanto as mulheres possuem pouca represen- 
tação e/ou problematização sobre sua importância para a sociedade e consequentemente para a história. Se formos ainda mais a fundo, podemos questionar ainda, onde estão às mulheres em suas histórias regionais e locais? Logo, percebemos inúmeras outras problemáticas, tais como as discussões acerca da dita história "nacional", a qual durante muito tempo privilegiou personagens do eixo Sul e o Sudeste do país e representada como a gênese pensante e como tal posicionamento reverbera até os dias de hoje.

Assim, é importante que enquanto professores/ pesquisadores abordemos as questões de gênero em sala de aula, no intuito de "conscientizar" os estudantes, dos mais variados níveis de ensino a importância de se pensar a história fora dos padrões escritos, principalmente os livros didáticos. Além disso, buscar apresentar as mulheres que também tiveram papel importante na história de seu bairro, cidade e estado, afinal a consciência histórica não possui manual, onde o espaço da mulher precisa ser melhor apresentado (CAVALCANTI JUNIOR, 2016).

Entendemos que uma das funções da educação é ser libertária, ou seja, permitir aos estudantes uma visão crítica de mundo, bem como lembrá-los da capacidade de transformação que tem em seus atos. Isso, tudo pode confluir para a contraposição de discursos totalizantes, bem como esquecimentos e negacionismo. Acreditamos que as representações continuarão sendo realizadas, contudo, entendemos que é preciso estarmos atentos a forma na qual elas estão sendo feitas. Uma vez que a educação precisa ter mais equidade não apenas no âmbito de sua conjuntura político-social, mas, também na prática pedagógica e em materiais didáticos.

\section{CONSIDERAÇÕES FINAIS}

Neste breve artigo apontamos algumas percepções que as representações promovem nos LDHs e como isso impacta diretamente no campo da educação, promovendo discursos e formas de observar o passado representado. Exemplificamos algumas mulheres, personagens e sujeitos históricos, e sabemos que poderíamos levantar inúmeras outras questões. Todavia, não é o escopo deste trabalho e nem haveria espaço para tanto. Mas a proposta foi não apenas propor respostas, mas sim, levantar questões e propormos uma reflexão acerca de nossa relação com os livros e a história das mulheres. 
A despeito disso, evocamos, ainda, que a análise de representações em LDHs deve se basear nas fontes seriadas, onde os dados podem ser tabulados tanto quanto forem possíveis. É sabido que nem sempre possuímos uma lista com todos os LDHs utilizados em determinada época e lugar. Assim, cabe o/a pesquisador/a ou professor/a estar atento/a ás nuances que as obras trazem e as possibilidades de sua utilização.

Além do mais, a investigação de representações em LDHs ou em outros LDs inserem-se na história da educação. Conforme Kênia Hilda Moreira há alguns aspectos que destacam a importância dos estudos sobre LDs para a história da educação. Dentre vários aspectos destacáveis, selecionamos à seguinte conclusão: "Em síntese, além do valor pedagógico do livro didático existem outros fatores nada descartáveis para a história da educação, como os fatores políticos, econômicos e sociólogos em geral" (MOREIRA, 2011, p. 28).

Por fim, entendemos que o caminho ainda é árduo por uma sociedade mais igualitária, algo que reverbera na educação. Os livros didáticos como ferramentas importantes no processo ensino-aprendizagem também é um grande propagador de discursos, sejam através de seus escritos e suas imagens/ representações. Esperamos que muito em breve este artigo se torne um estudo ultrapassado, tencionando em nossas práticas em sala de aula encontrar um tratamento igualitário no âmbito das representações e no tratamento das ações de homens e mulheres como protagonistas seja na história, ou nos mais variados campos da educação.

\section{REFERÊNCIAS}

BITTENCOURT, Circe. Ensino de História: fundamentos e métodos. São Paulo: Cortez, 2004.

BITTENCOURT, Circe. O saber histórico na sala de aula. $11^{\mathrm{a}}$ ed. São Paulo: Contexto, 2008

CASSIANO, C. C. D. F. O mercado do livro didático no Brasil: da criação do Programa Nacional do Livro Didático (PNLD) à entrada do capital internacional espanhol. Pontifícia Universidade Católica de São Paulo - PUC-SP. São Paulo. 2007.

CAVALCANTI JUNIOR, Ary A. História das mulheres e o ensino através de uma abordagem regional e local. In: Bueno, André; Estacheski, Dulceli T.; Zarbato, Jaqueline.

\section{9}


(Org.). Ensino de História e Estudos de Gênero. 1ed.Rio de Janeiro/ Nova Andradina: Sobre ontens, 2020, v. 1, p. 106-111.

CAVALCANTI JUNIOR, Ary A. Onde estão as mulheres na história? Reflexões e possibilidades em sala de aula. In: BUENO, André; ESTACHESKI, Dulceli; CREMA, Everton [orgs.]. Por um outro amanhã: apontamentos sobre aprendizagem histórica. Rio de Janeiro/União da Vitória: Edição Ebook LAPHIS/Sobre Ontens, 2016.

CHOPPIN, A. História dos livros e das edições didáticas: sobre o estado da arte. Educação e Pesquisa, São Paulo, v. 30, p. 549-566, set./dez. 2004.

CHARTIER, Roger. A história cultural: entre práticas e representações. Lisboa: Difel, 1990.

CHARTIER, Roger. Defesa e ilustração da noção de representação. Revista Fronteiras, Dourados, MS, v. 13, n. 24, p. 15-29, jul./dez. 2011.

CAPELLARI, Marcos Alexandre. Ficção e história: fato, imaginação e representações. Revista Margens, São Paulo, n. ${ }^{\circ}$ 4, 2006.

COELHO, Raphael P. R. A memória de um heroína: a construção do mito de Maria Quitéria pelo exército brasileiro. $143 \mathrm{fl}$. Dissertação (mestrado). Programa de Pós-Graduação em História. Universidade Federal Fluminense. Niterói, 2019.

COLLING, Ana Maria. Tempos diferentes, discursos iguais: a construção do corpo feminino na história. Dourados, MS: Ed. UFGD, 2014

FERRO, Marc. A História Vigiada. São Paulo: Martins Fontes, 1989.

FOUCAULT, Michel. Vigiar e punir: nascimento da prisão. Trad. Raquel Ramalhete. 42 ed. Petrópolis, Rio de Janeiro, 2014.

MAAMARI, A. O ensino laico e a formação filosófica. Revista Eletrônica de Educação, Vol. 8, No 3 (2014). Disponível em: <http://www.reveduc.ufscar.br/index.php/ reveduc/article/view/1090 > . Acesso em: 12 mar. 2015.

MARTINS, R. de A. As primeiras investigações de Marie Curie sobre elementos radioativos. Revista da Sociedade Brasileira de História da Ciência, v. 1, n. 1, p. 29-41, 2003.

MOREIRA, Kênia Hilda. O ensino de História no Brasil no contexto republicano de 1889 a 1950 pelos livros didáticos: análise historiográfica e didático-pedagógica. 234 fl. Tese de doutorado em Educação Escolar. Araraquara, UNESP: 2011. 
MUNAKATA, Kazumi. Produzindo livros didáticos e paradidáticos. $223 \mathrm{fl}$. Tese (Doutorado em Educação) - Pontifícia Universidade Católica de São Paulo, São Paulo, 1997.

MUNAKATA, K.. O livro didático como mercadoria. Pro-posições, 23, set./dez. 2012. 51-66.

NEGREIROS, Adriana. Maria Bonita: sexo, violência e mulheres no cangaço. São Paulo. Objetiva, 2018.

OLIVEIRA, Wilson. A imagem da mulher nos livros didáticos e relações de gênero. Revista Fórum identidades. Itabaiana: GepiaddE, Ano 5, Volume 9 , jan-jun de 2011.

ROCHA, H. Um novo paradigma de revisão de texto: discurso, gênero e multimodalidade. 2012. xi, 246 f., il. Tese (Doutorado em Linguística)—Universidade de Brasília, Brasília, 2012.

SCOTT, Joan. Gênero: uma categoria útil de análise histórica. Educação \& realidade, v. 20, n. 2, 1995.

SILVA, Juliana. Ensino de história e questões de gênero nos livros didáticos. Anais eletrônicos do VI encontro estadual de história, ANPUH/BA, 2013.

TEDESCHI, Losandro Antônio. As mulheres e a história: uma introdução teórico metodológica. Dourados, MS: Ed. UFGD, 2012. 


\section{A CIDADE E O FAZER OPERÁRIO: TECENDO TERRITORIALIDADES E REPRESENTAÇÕES DO CENTRO A PERIFERIA, DO TRABALHO AO LAR (BELÉM-PA, 1930-1935)}

José Ivanilson da Luz Rodrigues ${ }^{29}$ Jairo da Silva e Silva ${ }^{30}$

29 Professor de História na Faculdade de Educação e Tecnologia da Amazônia (FAM) e na Secretaria de Educação do Pará (SEDUC/PA). Pela Universidade Federal do Pará (UFPA) é Licenciado em História; Especialista em Relações Étnico-Raciais; Mestre em História e Doutorando do Programa de Pós-Graduação em História Social da Amazônia. E-mail: rodrigues_ivanilson@yahoo. com.br.

30 Professor na área de Letras no Instituto Federal do Pará (IFPA). Licenciado em Letras pela Universidade Estadual do Maranhão (UEMA); Mestre em Letras pela Universidade Federal do Pará (UFPA); Doutorando em Letras: Linguagens e Representações pela Universidade Estadual de Santa Cruz (UESC). E-mail: jairo.silva@ifpa.edu.br. 


\section{INTRODUÇÃO}

Este trabalho ocupa-se das possibilidades historiográficas acerca da cidade como palco da tessitura de sociabilidades, de alterações materiais e simbólicas, a partir das demandas da gente laboriosa da capital paraense, Belém, na primeira metade da década de 1930. Para tanto, recorremos à análise de documentos alocados no APEP - Arquivo Público do Estado do Pará (cartas, memoriais, ofícios, portarias, etc.) e jornais da época (A Crítica, Diário da Tarde, O Imparcial e Folha do Norte).

As discussões aqui apresentadas assentaram-se nas premissas de Pesavento (2007), acerca da cidade como espaço de alteração material e simbólico, sensível; Carpintéro \& Cerasoli (2009), sobre o fecundo diálogo da história com as demais áreas do conhecimento no construto historiográfico acerca da cidade; Heidrich (2008; 2010), acerca da constituição de territorialidades entre as classes populares, em áreas periféricas; e ainda, Decca (1983), concernente a vida fora das fábricas, condições de deslocamentos e moradia do operariado.

Pelas análises aqui empreendidas, constatamos a relação entre conjuntura política, demanda social, lutas e resistências reconfigurando a paisagem urbana, a partir de demandas de vida e trabalho da gente laboriosa do lar à fábrica, da periferia ao centro urbano.

\section{HISTORIOGRAFIA DOS MUNDOS DO TRABALHO: UMA BREVE INTRO- DUÇÃO, NOVAS POSSIBILIDADES}

As pesquisas concernentes aos mundos do trabalho vêm ganhando maior alcance nas últimas décadas, sobretudo a partir do tangenciamento de recursos analíticos construídos sob um viés interdisciplinar (conjuntura reverberante desde os primórdios dos Annales): teoria da agência, territorialidade, gênero, representação, etc. Nesse sentido, torna-se possível o empreendimento de abordagens antes negligenciadas e/ou secundarizadas pelo historiador, como as relações: trabalho - lar, centro - periferia, entre outras, de forma a fomentar análises mais acuradas acerca do macro-campo do trabalho, pois

Já nos inícios dos anos 1990, os estudos de historiadores e sociólogos sobre a cidade e possibilitou uma série de trabalhos voltados para a temática da moradia operária, do sanitarismo, engenharia, arquitetura, urbanismo, memó-

\section{3}


ria e patrimônio histórico em São Paulo, como em outras cidades do Brasil. (CARPINTÉRO; CERASOLI, 2009, p. 14).

Por meio de intervenções ou pedidos de cessão de terrenos, construção de moradias e/ou serviços sanitários, entre outros, nos-é possível observar o diálogo com as demais áreas do conhecimento, e ainda, as alterações na paisagem urbana das cidades sob uma demanda da horda operária, a gente laboriosa. Conjuntura notada na capital paraense, nos idos da década de 1930.

O alvorecer da década de 1930, no Pará, revela um panorama de rearranjos políticos, aquecimento e arrefecimento da atividade industrial, aumento das demandas sociais referentes à classe trabalhadora, entre outras coisas. Panorama observado nas páginas dos jornais (A Crítica, Diário da Tarde, O Imparcial e Folha do Norte) e nos documentos endereçados e despachados pelo Governo do Estado (cartas, ofícios, decretos, memoriais, etc.): "Foi nos fins do século XIX que o Estado compreendeu que devia intervir em favor do operariado, para limitar as horas de trabalho, assegurar as condições de higiene, reprimir as explorações dos capitalistas e... para a construção de suas casas" 31 .

Notamos pelo excerto, que as demandas sociais do operariado transpunham a questão salarial e a exploração da mão de obra em vastas jornadas de trabalho, alcançando dimensões referentes aos espaços vivenciados física e simbolicamente, dentro e fora do ambiente de trabalho: higiene e moradia; a primeira, como uma problemática que em muitos casos conspirava contra a saúde do trabalhador, acompanhando-o até mesmo em seu espaço de moradia, como a realidade das operárias exposta nos jornais da época: “... entretanto, as miseras abelhas, obreiras dessas fortunas, passam fome e moram em lôbregos casebre." ${ }^{2}$; a segunda, como uma condição de exclusão social (pelas más condições ou mesmo pela ausência de propriedade), que em muito dificultava a sobrevivência cotidiana das classes laboriosas, inclusive em seus deslocamentos e acessos aos locais de trabalho ${ }^{33}$.

Segundo Pesavento (2007), a compreensão das dinâmicas nas cidades deve ser pensada não apenas a partir das alterações materiais ocorridas nesta, é preciso pensa-la como espaço de sociabilidade, de entrecruzamento de diversos atores

$31 \quad$ Memorial sobre a questão social do operariado, apresentado pela Liga Nacionalista do Pará à Interventoria Federal do Pará. APEP - Arquivo Público do Estado do Pará: Fundo Gabinete do Interventor; Série: Ofícios, 1931.

$32 \quad$ A Crítica, 03. 01. 1933. p. 01.

33 Folha do Norte, 06. 02. 1930, p. 08.

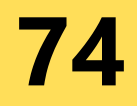


sociais, personagens, classes, grupos sociais, práticas de interação e oposição, de fazer-se de hábitos, assim

A cidade é concentração populacional, tem um pulsar de vida e cumpre plenamente o sentido da noção do 'habitar', e essas características a tornam indissociavelmente ligada ao sentido do 'humano': cidade, lugar do homem; cidade, obra coletiva que é impensável no individual; cidade, moradia de muitos, a compor um tecido sempre renovado de relações sociais. (PESAVENTO, 2007, p. 14).

As formas de ocupação do espaço urbano, suas semelhanças e incongruências observadas na relação centro-periferia, nos apresentam importantes ferramentas para compreender os espaços de vivência e ocupação "permanente" e "transitória" do operariado, nesse sentido nos assentaremos às reflexões de Junior \& Santos (2009), para quem as demandas por ocupações humanas surgidas em dados momentos fazem emergir ações estatais no tocante a concessão e/ou intervenção sobre novos espaços habitacionais.

Outro importante aporte teórico-metodológico, aqui utilizado, referente à construção de territorialidades e representações são as reflexões de Heidrich (2008), para quem é possível dentro deste contexto, suscitar-se a formação de uma territorialidade das classes populares, inserta nesse processo encontra-se ainda, a produção e ressignificação das representações, entre outras coisas.

Segundo Heidrich (2010, p. 08): "A territorialidade que alguns vivem pode se diferenciar da territorialidade de outros, pois vai depender do meio a que se tem acesso", neste ponto, suscitamos a construção de territorialidades em espaços de habitação e transitoriedade da classe laboriosa, de forma a adentrar em um ambiente cotidiano de vida e trabalho das operárias da capital paraense, pois:

As relações que os grupos mantem com o seu meio não são somente materiais, são também de ordem simbólica, o que os torna reflexivos. Os homens concebem seu ambiente como se houvesse um espelho que, refletindo suas imagens, os ajuda a tomar consciência daquilo que eles partilham. (CLAVAL, 1999, p. 11).

A dinâmica de ocupação do espaço urbano ganhou maior intensidade e complexidade com o advento da atividade industrial em grande escala, a partir do século XVIII na Inglaterra (HOBSBAWN, 2002). No Brasil, já no final dos novecentos, e, sobretudo nas primeiras décadas do século XX, observa-se o crescimento dos estabelecimentos industriais nas grandes cidades, conjuntura que favoreceu a ocupação 
do espaço urbano, também pelo contingente operário (DECCA, 1983), não apenas como fator de propulsão produtiva dando "vida" às fábricas e oficinas, mas demandando moradia, ora anexa aos locais de trabalho, ora em áreas periféricas, e por vezes, com baixo nível de saneamento, entre outras coisas, que dificultava a vida do operariado nos deslocamentos centro-periferia, realidade esta, cara a cidade de Belém no início dos anos de 1930.

De acordo com Darcy Flexa Di Paolo (1981, p. 41): “Depois de 1930, Belém tornou-se o centro do movimento sindical na Amazônia, com expressão nacional, e com objetivos reivindicatórios em termos especificamente salariais. A greve da Pará-Eletric, é um exemplo deste movimento de base". O que nos permite inferir o acentuado nível de atividade industrial em Belém, sobretudo em bairros como o Reduto (SOUSA, 2009). Tal efervescência de instalação e atividade fabril na capital paraense fez crescer vertiginosamente o número de homens e mulheres empregados nestes espaços produtivos, o que entre outras coisas, fez crescer as demandas por espaços de moradia a esta horda laboriosa.

\section{OCUPAÇÃo dO ESPAÇO URBANO NA CAPITAL PARAENSE: DEMAN- DAS OPERÁRIAS E O ESTADO}

Neste contexto, as preocupações referentes aos espaços de sociabilidades compartilhados entre o operariado da capital paraense (trabalho e lar, e suas circunvizinhanças), eram latentes no início da década de 1930, podendo ser notadas no encaminhamento de denúncias e protestos na mídia local ou mesmo diretamente ao Governo do Estado, de forma individual ou coletiva: "A Municipalidade de Belém tem no Bairro da Pedreira terrenos devolutos de sua propriedade, o operariado pede a V. Ex. a sua preferência para a construção de suas casas, de tipo uniformizado pela Prefeitura." ${ }^{34}$.

O excerto é parte constitutiva de um Memorial encaminhado à Interventoria Federal no Pará, onde constavam denúncias e reivindicações de natureza diversa, estando o documento dividido em: horas de trabalho; higiene das fábricas e assistência industrial; acidentes de trabalho; aprendizes artífices; escolas para operários; casas para operários; cadernetas sanitárias e profissionais; operariado feminino; e salários.

Chama a atenção, a demanda pela construção de casas ao operariado, nas

$34 \quad$ APEP - Arquivo Público do Estado do Pará; Fundo: Gabinete do Interventor; Série: Ofícios $-1931$.

76 
chamadas terras devolutas, em grande medida, concessões territoriais não utilizadas, o que revela importantes facetas do cotidiano desses trabalhadores: ocupação de habitações nas áreas periféricas, por vezes, distantes de seus locais de trabaIho; moradias com extremas limitações estruturais (barracos/barracas); ausência de propriedade; ameaça de despejo; entre outras. Conjuntura também observável, em cartas enviadas ao Interventor Magalhães Barata:

Eu, Narcisa da Graça Pìnto, inutilizada, mutilada, vivo do trabalho de duas filhas que são meu único arrimo.

Mandei com todo sacrifício e economia privando-nos até do necessário, levantar uma barraca na Tito Franco, próximo a Estrada de Rodagem, no terreno de D. Sinhá Amazonas de Figueiredo que tem sido uma protetora, vendo a minha extrema pobreza permitindo que, eu construísse um teto em seu terreno.

Depois de muitas despesas e da barraca estar quase pronta, recebi uma ordem de V. Ex. por um fiscal para demoli-la. ${ }^{35}$

A condição de uma mãe sendo sustentada por duas filhas, ou seja, por duas jovens trabalhadoras, parece associar-se a um panorama recorrente nas fontes: o sustento de famílias sob a responsabilidade de moças "chefes de família", comumente reconhecidas como "jovens operárias". Além disso, a situação de exclusão social refletida sobre a ameaça de despejo, e ocupação de áreas periféricas demonstra a transitoriedade cotidiana dessas operárias, entre o lar, área de limitações estruturais e saneamento (bairros como: Guamá, Marco da Légua, Pedreira, etc.), e o trabalho, comumente alocado na área central da cidade (em grande medida, os bairros Reduto (SOUSA, 2009), Marco ${ }^{36}$, Pedreira, etc., além de locais que demandavam deslocamentos mais longos, como: Ilha das Onças ${ }^{37}$ e llha de Mosqueiro). ${ }^{38}$

A demanda habitacional do operariado, que se refletia de forma diversa: solicitações de redução das "décimas anuais" (imposto predial); a habitação em casebres, no mais das vezes, de madeira; e a solicitação de terrenos devolutos para a construção de casas ao operariado; não passava sem a atenção do poder instituído na Primeira Interventoria de Magalhães Barata, acerca da redução dos preços dos alugueis, o Interventor baixara o Decreto $n^{\circ} 48$ de 09 de dezembro de 1930, que

$35 \quad$ APEP - Arquivo Público do Estado do Pará; Fundo: Gabinete do Interventor; Série: Cartas $-1933$.

36 O Imparcial, 06, 11, 1933, p. 04.

37 Folha do Norte, 23. 01. 1930, p. 06.

38 Folha do Norte, 09. 05. 1930, p. 02. 
garantia: "Ao interventor, ficaria reservada a faculdade de fiscalizar pessoalmente, ou por terceiros, os preceitos estatuídos, e poderia aplicar a pena pecuniária de três dobros dom aluguel originário..." (CASTRO, 2011, p. 35).

Como forma de empreender no núcleo urbano da capital paraense uma prática recorrente na Primeira Interventoria: a apropriação pelo estado das terras devolutas, Magalhães Barata, baixa o Decreto no 167 - A, de 06 de março de 1931, que em muito atendia a uma demanda habitacional do operariado da capital, pois: "extinguiu diversos contratos de efiteuse (direito real de posse, uso e gozo de um imóvel) de terrenos situados nos bairros da Pedreira e Telégrafo, até a margem da baia de Guajará..." (CASTRO, 2011, p. 47).

Tal decreto, motivava sua homologação mediante a constatação de que os proprietários de tais terras não estavam usufruindo destas, e, nem tampouco, pagando "as taxas devidas ao órgão competente". Como forma de atendimento às demandas habitacionais do operariado, explicitadas e intensificadas a partir de 1930, a Interventoria regulamentou a ocupação desses terrenos, de forma a favorecer a classe laboriosa de Belém:

Mas, considerando que estas terras estavam, em grande parte, edificadas por famílias pobres, o interventor baixou o Decreto $n^{\circ} 170$, de 07 de março de 1931, dispondo sobre a preferência para a lavratura do termo de aforamento dessas áreas. Cada pessoa teria o direito de aforar somente um lote e o pagamento deste serial mensal, não sendo permitido atrasar mais que três prestações. Sob pena de perda do direito preferencial. (CASTRO, 2011, p. 47).

Esta conjuntura de anulação das concessões das terras devolutas, e a posse destas sendo entregues à Prefeitura de Belém, e posteriormente, em parte, repassadas às classes pobres, laboriosas, ganhou maior amplitude com a publicação do Decreto $n^{\circ} 193$, de 14 de março de 1931, pois desta feita

A decisão abrangeu terrenos nos bairros de São Brás, Marco e Matinha, compreendendo a Praça Floriano Peixoto, as avenidas José Malcher, almirante Barroso, 25 de Setembro, Duque de Caxias, ruas Jõao Balbi, Boaventura da Silva, Domingos Marreiros, Antônio Barreto, travessas Castelo Branco, Antônio Baena, Curuzu, Chaco e Humaitá. (CASTRO, 2011, p. 48-49).

A expansão da ocupação do espaço urbano em áreas antes subutilizadas, áreas periféricas, parece fomentar a construção de uma "territorialidade das clas- 
ses populares", não de forma isolada de outras territorialidades existentes no meio urbano, como a dos bairros centrais e/ou comerciais, mas que está em permanente diálogo, assimilação e mesmo preservação de traços peculiares às áreas periféricas, onde comumente: "Predominam as relações de vizinhança, pouco frequentes nas territorialidades de classes abastadas, tendendo à intensificação das territorialidades de menores rendas" (HEIDRICH, 2008, p. 307).

Assim o cotidiano de intempéries sociais, partilhado por moradores de bairros periféricos, caracterizados pela precariedade nas condições de saneamento, transporte, iluminação, etc., faz crescer a necessidade de intervenção estatal nestes locais:

\begin{abstract}
Nesta perspectiva, de surgimento de uma nova centralidade em setores da periferia, a ação do poder público é necessária para a instalação de infraestrutura urbana, intervindo também, de forma direta ou indireta, na questão dos assentamentos humanos, através do financiamento, seja para a população e/ ou empresários. Consequentemente, essa atitude reflete não só na demanda por moradia, mas também no processo de acumulação capitalista. (JUNIOR; SANTOS, 2009, p. 354).
\end{abstract}

Para além, das alterações no espaço urbano, advindas de demandas sociais e intervenções do poder público, Pesavento (2007) suscita a constituição de uma cidade imaginária, sensível, conformada nas formas de identificação e simbolismo dos lugares e formas de vivenciá-los, já que

\begin{abstract}
Essa cidade sensível é uma cidade imaginária construída pelo pensamento e que identifica, classifica e qualifica o traçado, a forma, o volume, as práticas e os atores desse espaço urbano vivido e visível, permitindo que enxerguemos, vivamos e apreciemos desta ou daquela forma a realidade tangível. A cidade sensível é aquela responsável pela atribuição de sentidos e significados ao espaço e ao tempo que se realizam na e por causa da cidade. (PESAVENTO, 2007, p. 14-15).
\end{abstract}

As formas diversas de lidar com o espaço habitado, conforma-se nas relações simbólicas construídas, que manifestam-se, por exemplo, em manifestações religiosas, como enunciara De Campos Ribeiro (2005), ao referir-se às práticas vivenciadas no período da Semana Santa nos bairros de Belém, ainda nas primeiras décadas do século XX: "A gente do bairro, essa fazia ato de fé ouvindo o novenário, pagando promessas por alguma graça... Dentre tais votos destacava-se o sacrifício que era ir buscar o "Mastro lá pras bandas da Sétima da Pedreira, onde oito dias antes fora cortado" (RIBEIRO, 2005, p. 59-60), o excerto guarda expressões da territorialidade 
construída nestes espaços que expressão como locais de contato fixo e de transitoriedade: "Aos balanços, em ginga, de mar picado, lá ia, da Pedreira ao Umarizal o 'Mastro'” (RIBEIRO, 2005, p. 59-60), nesta manifestação cultural típica das décadas iniciais do século XX, na paisagem urbana da capital paraense, uma cantiga ressoava, demonstrando a ocupação da mulher no espaço público do trabalho, ainda eivada de ofício doméstico: "Lavadeira da Campina, lavadeira! Lava roupa sem sabão, Lavadeira..." (RIBEIRO, 2005, p. 59-60).

Permeadas por essa possível "territorialidade das classes populares", e pela efervescência das relações de vizinhança, em muito acentuadas pelas formas de lidar com o espaço de vivência, as classes laboriosas destas áreas periféricas passam a encaminhar protestos tocantes às condições estruturais dos espaços públicos em que vivem:

Moradores da Pedreira reclamam contra o fato da iluminação pública daquele bairro apagar-se às 5 horas da manhã, alegando que essa medida prejudica aos moradores locais que tem de sair ainda no lusco-fusco para o trabalho, principalmente muitas mulheres e meninas empregadas nas fabricas e que ficam sujeitos a partir uma perna nos covões e depressões existentes no terreno. Pedem por isso a atenção do gerente da Pará Elétrica ${ }^{39}$.

A matéria jornalística inserta na seção "Reclamações do Povo" do Jornal Folha do Norte, revela estratégias cotidianas de vivenciar o espaço habitado, um diálogo cotidiano de limitações estruturais física e socioeconômica, adaptações às intempéries e a tessitura do convívio em espaços diferenciados; a saída ainda de madrugada de suas casas em direção às fabricas pelas operárias, suscita as condições de dificuldade no tocante aos deslocamentos do lar ao trabalho e vice-versa, pois é sabido, que o Bairro da Pedreira preserva certa proximidade ao centro de Belém, em especial ao Reduto, o que nos permite inferir o longo tempo de caminhada até encontrar condução para o trabalho, prática piorada pelas precárias condições de saneamento e preservação das ruas, alvo de constantes denúncias da população:

Moradores do futuroso bairro da Pedreira, onde possuímos casas de comercio, deplorando as condições de verdadeira ruína a que chegou a rua Pedro Miranda, desde o ponto em que extrema com a rua Bernal do Couto até o de junção com a rodovia Lomas Valentinas, apelamos por intermédio da FOLHA para o sr. Intendente, na certeza de obter do sr. O melhoramento daquela importante via pública em bem da população... a rua Pedro Miranda em que se vê grandes sulcos abertos pelos caminhões carregados de pedras do aludido 
A alusão ao "futuroso bairro da Pedreira" na verdade indica o construto de uma representação social em torno do bairro, que acabava atendendo aos interesses de grande parte das classes laboriosas, e ainda servia como um construto de identificação social: o bairro operário. Segundo Moscovici (2003 apud HEIDRICH, 2008, p. 301):

Os sistemas de classificação e de nomeação (...) não são, simplesmente, meios de graduar e de rotular pessoas ou objetos (...). Seu objetivo principal é facilitar a interpretação de características, a compreensão de intenções e motivos subjacentes às ações das pessoas, na realidade, formar opiniões.

Nesse sentido, notamos a formação de uma representação na qual a Pedreira aos poucos deixava de ser apenas uma área marginalizada, como de extração de pedras, de circulação de caminhões e de ruas esburacadas, para ganhar maior civilidade com a ocupação de comércios, e a construção de casas ao operariado: "A Pedreira poderá assim, ser de fato, o bairro operário de Belém, com um tipo de casas baratas, obedecendo, entretanto, a estética e higiene das habitações modernas" ${ }^{41}$. Nesse sentido, é possível compreender as peculiaridades da ocupação em grande escala da Pedreira nos inicios da década de 1930, o perfil populacional, a territorialidade construída sob o apanágio da natureza e vivencia naquele espaço, etc.:

O populoso bairro da Pedreira desde que foi servido com uma linha de bondes, que se povoou de moradores na sua maioria gente humilde e trabalhadora... A natureza para aquelas paragens é digna de ser apreciada, principalmente à tarde, quando o pitoresco bairro deixa ver suas casinhas e barracas movimentadas de mulheres, homens e crianças, numa simplicidade encantadora. $^{42}$

A demanda criada acerca do caráter operário do bairro da Pedreira difundia-se tão fortemente no meio social de Belém que até eventos político-partidário viam a necessidade de acionar tal representação: "Com crescida honra convido V. Ex. para assistir ao comício cívico, popular-proletariado que a pobreza e o povo da Pedreira com o concurso deste Partido, vai realizar no próximo domingo..."43. As demandas $40 \quad$ Folha do Norte, 24. 03. 1930, p. 03.

41 APEP - Arquivo Público do Estado do Pará; Fundo: Gabinete do Interventor; Série: Ofícios $-1931$.

$42 \quad$ Folha do Norte, 22. 03. 1930, p. 03.

43 APEP - Arquivo Público do Estado do Pará; Fundo: Gabinete do Interventor; Série: Cartas $-1931-1933$. 
acerca do construto social circundante à Pedreira como bairro operário, era compartilhado por operários e operárias, inclusive nos casos de acidentes: "verificou-se no bairro da Pedreira, um atropelamento que por pouco não custou a vida de um pobre operário quer àquela hora se dirigia para o trabalho"44.

As formas de vivenciar esses bairros periféricos, como o bairro operário da Pedreira imputava aos operários e operárias e suas famílias, estratégias de vivência que por vezes, remetiam-se ao assistencialismo governista, ou mesmo a sua ausência: "os pobres que possuíssem uma única barraca e nela residissem, bastavam requerer a isenção do pagamento de décimas urbanas, bem como o abatimento de $50 \%$ dos débitos em atraso... nessas miseráveis choupanas" ${ }^{45}$. Além das reclamações e pleiteamentos por questões assistencialistas, protestos quanto às condições estruturais do bairro operário da Pedreira eram encaminhadas, inclusive suscitando demandas das mulheres operárias:

Moradores da Travessa Estrela perímetro compreendido que vai da 25 de Setembro até a Pedreira, chamam a atenção de quem de direito, para o estado lastimável que se encontra aquele trecho nestes últimos dias de chuva, os moradores quando chegam na esquina da 25 de Setembro tiram os sapatos para poderem chegar em casa. ${ }^{46}$

Moradores da Pedreira reclamam contra o facto da iluminação pública daquele bairro apagar-se às 5 horas da manhã, alegando que essas medidas prejudicam os moradores locais que tem de sair ainda no fusco-fusco para o trabalho, principalmente muitas mulheres e meninas empregadas em fabricas e que ficam sujeitas a partir nos covões e depressões existentes no terreno. Pedem, por isso, a atenção do gerente da Pará Elétrica, por nosso intermédio 47 .

Chama a atenção nestes excertos, a presença de muitas mulheres operárias das fabricas de Belém no "populoso bairro da Pedreira", outro elemento, acerca da condição de jovens moças como "chefes de família", ou seja, meninas operárias que seguiam carreira no ofício das fábricas da capital paraense, algumas tinham que sair ainda cedo devido aos horários dos bondes e aos locais de trabalho, por vezes a llha das Onças e em Mosqueiro, além das fábricas do Reduto.

O construto social acerca de possíveis locais habitados pelo operariado e necessariamente tratados como tal, como o "populoso bairro operário da Pedreira", representação social, cunhada por dois condicionamentos principais: a solicitação $44 \quad$ O Imparcial, 09. 07. 1935, p. 04.

45 O Imparcial, 30. 07. 1935, p. 01.

$46 \quad$ O Imparcial, 19. 12. 1935, p. 02.

47 Folha do Norte, 06. 02. 1930, p. 08; O Imparcial, 20. 03. 1934, p. 02. 
empreendida pelos operários acerca da cessão das terras devolutas do bairro da Pedreira ${ }^{48 ;}$ e a concretização de uma ocupação exasperada pelo operariado masculino e feminino nos idos do decênio de $1930^{49}$, e em muito atendido por concessões oficiais, não esgotou ações pontuais do governo no que tange a construção de casas ao operariado em locais diferentes, como o bairro da Uzina de Cremação.

Nos idos de 1932 o jornal O Imparcial, publica uma matéria intitulada: Bellas Iniciativas de uma iniciativa de uma administração modelar: A Prefeitura de Belém assignou contracto para a construção de 24 casas para operários, na matéria ficava explícita a intenção do governo em construir uma Vila Operária no bairro da Uzina de Cremação, atualmente conhecido como bairro da Cremação.

O governo Revolucionário do Pará, a cada dia que passa, está resolvendo problemas importantíssimos que sempre descuidados. O governo do Estado orientado por uma vontade hercúlea e cheia dos mais patrícios anseios, vem surpreendendo a todos por suas iniciativas arrojadas...

Ainda agora, a Prefeitura de Belém acaba de lavrar contrato com o Sr. Sebastião R. de Oliveira para construção de uma vila operária, destinada a dar ao pobre trabalhador essa arejada, higiênica e barata. Serão 24 casas para serem alugadas para operários, no bairro da Uzina de Cremação. ${ }^{50}$

A construção de casas em benefício dos operários, por iniciativa do governo, na verdade revela uma demanda por moradia do operariado da capital paraense, empreendida por meio de reivindicações ao governo ${ }^{51}$ e por meio da própria imprensa local, suscitando as condições favoráveis de aquisição de tal demanda pelo operariado do sul e sudeste do Brasil: "No Sul, o Rio, por exemplo, observamos o interesse de todo trabalhador em possuir sua casinha, que lhe possa dar conforto, o conforto bem digno da companheira dedicada que lhe ameniza as horas dos aborrecimentos." 52 .

A construção das casas direcionava-se "também por funcionários de parcos vencimentos, as quais preenchem as condições higiênicas e solucionam o problema de habitações baratas ao alcance das possibilidades do proletariado."53. Abaixo vemos relacionados os preços das casas destinadas aos operários de acordo com o poder público:

48 APEP - Arquivo Público do Estado do Pará; Fundo: Gabinete do Interventor; Série: Ofícios $-1931$.

49 Folha do Norte, 06. 02. 1930, p. 08.

50 O Imparcial, 22. 11. 1932, p. 01.

51 APEP - Arquivo Público do Estado do Pará; Fundo: Gabinete do Interventor; Série: Ofícios $-1931$.

52 Diário da Tarde, 26. 05. 1932, p. 07.

53 O Imparcial, 22. 08. 1933, p. 01. 
Tabela 1 - valores das casas destinadas ao operariado

\begin{tabular}{|c|c|c|}
\hline Capital & Aluguel Mensal & Aluguel Semanal \\
\hline TIPO A - 2: $230 \$ 000$ & $20 \$ 000$ & $5 \$ 000$ \\
\hline TIPO B - 2: $956 \$ 000$ & $32 \$ 000$ & $8 \$ 000$ \\
\hline TIPO C - 3: $520 \$ 000$ & $40 \$ 000$ & $10 \$ 000$ \\
\hline TIPO A - 4: $177 \$ 000$ & $48 \$ 000$ & $12 \$ 000$ \\
\hline
\end{tabular}

Fonte: O Imparcial, 22. 08. 1933, p. 01.

As casas atendiam na prática a dois formatos de construções principais: 1) Sohenia dos compartimentos e 2) A fachada do <bangalô> cujo preço vai de 8: $000 \$ 000$ a 12: 000\$000. A arquitetura das casas, apesar de não ser tão extensa, ainda assim, comportava dois quartos, sala, sala de jantar, cozinha, e área de serviço.

Figura 1 - modelos das casas destinadas ao operariado

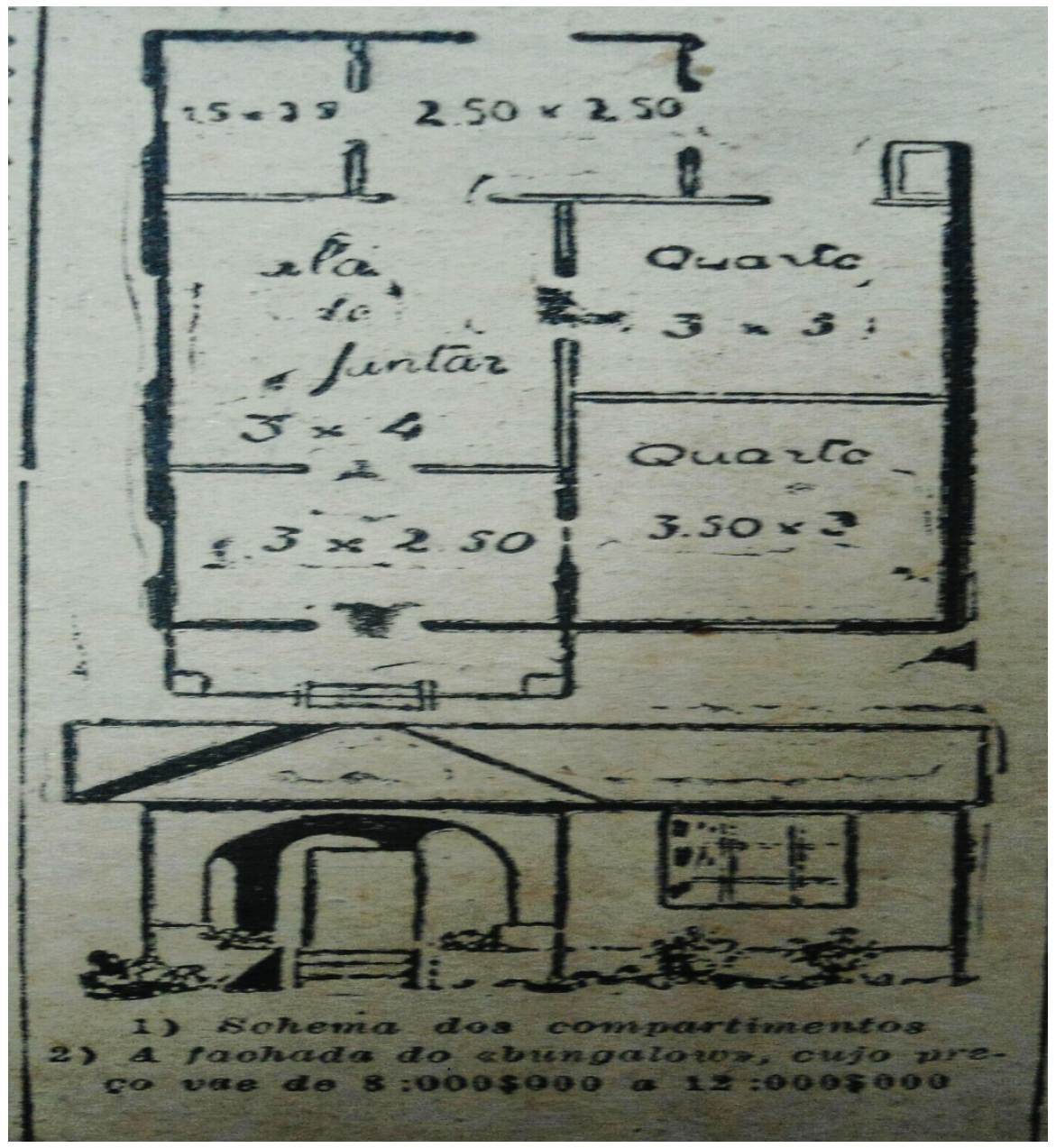

Fonte: Diário da Tarde, 11.11, 1932, p. 02.

\section{4}




\section{CONSIDERAÇÕES FINAIS}

A historiografia das cidades emerge como um amplo campo de abordagem histórica, por possibilitar o entre cruzamento de diversificadas áreas do conhecimento, e ainda, de outras abordagens já consagradas: trabalho, gênero, sindicalismo, operariado, cultua, política, etc. $O$ trabalho na Amazônia no século XXI, vem sendo construída sob um importante viés de diálogo entre a emergência de novas fontes (cartas, ofícios, abaixo-assinados, etc.), e, um efervescente aporte teórico "inovador" erguido nas ciências humanas: teoria da agência, gênero, estratégia, sistemas sociais fraturados, territorialidades, espaços de trânsito: centro-periferia (lar-trabalho), entre outros. A Possibilidade de adentrar no espaço das cidades pelas "festas das janelas" da vida cotidiana da gente laboriosa da capital paraense, reconstituir experiências vividas e percebidas, suas estratégias de encaminhamento às demandas sociais a patronato e poder público, parece um terreno fértil de análise, ainda em construção.

Os resultados da pesquisa que apresentamos por agora, constitui-se em um estudo introdutório acerca das experiências de vida do proletariado no espaço das cidades, para além da abordagem tradicional da história do trabalho: àquela que se debruça sobre a exploração do trabalho no ambiente fabril; ou, às disposições estatais quanto às questões trabalhistas; ou mesmo, àquela que se ocupa de uma história associativista do operariado.

Portanto, nossa intenção foi estabelecer diálogo com terminologias circundantes nas ciências humanas para melhor compreender a dinâmica social construída na cidade de Belém de vida de sujeitos sociais concretos, visualizados em suas demandas materiais e simbólicas na paisagem urbana de Belém do Pará nos anos iniciais do decênio de 1930.

\section{REFERÊNCIAS}

BLOCH, Marc. Apologia da história, ou, $\mathbf{O}$ ofício de historiador. Jorge Zahar Ed. Rio de Janeiro: 2001.

CARPINTÉRO, Marisa Varanda Teixeira; CERASOLI, Josianne Francia. A cidade como história. História: Questões \& Debates, v. 50, n. 1, p. 61-101, jan./jun. 2009.

CASTRO, Ribamar. Atos dos Governadores: 1930-1937. Belém: Imprensa Oficial 
do Estado, 2011.

CLAVAL, Paul. O território na transição da pós-modernidade. GEOgraphia. v. 1, n. 2 , p. 07-26, 1999.

DECCA, Maria Auxiliadora Guzzo. A vida fora das fábricas: cotidiano operário em São Paulo - 1927-1934. 1983. Dissertação (Mestrado) - Universidade Estadual de Campinas, Instituto de Filosofia e Ciências Humanas, Campinas. Disponível em: http://www.repositorio.unicamp.br/handle/REPOSIP/281815. Acesso em: 02 mar. 2021.

DI PAOLO, Darcy Flexa. O Trabalhador da estiva: um estudo sociológico sobre os estivadores do Pará. Belém: CEPAS, 1981.

HEIDRICH, Álvaro Luiz. Sobre os nexos entre espaço, paisagem e território em um contexto cultural. In: SERPA, Ângelo (org.). Espaços Culturais: vivências, imaginações e representações. Salvador: EDUFBA, 2008, p. 293-311.

HEIDRICH, Álvaro Luiz. A abordagem territorial e a noção de representação. Anais XVI Encontro Nacional dos Geógrafos - Crise, práxis e autonomia: espaços de resistência e de esperanças - Espaço de Socialização de Coletivos. Porto Alegre, 2010.

HOBSBAWN. Eric J. A Era do Capital. São Paulo: Paz e Terra, 2002.

JUNIOR, Wilson Martins Lopes; SANTOS, Regina Célia Bega dos. Novas centralidades na perspectiva da relação centro - periferia. Sociedade \& Natureza, v. 21, n. 3, p. 351-359, dez. 2009.

PESAVENTO, Sandra Jatahy. Cidades visíveis, cidades sensíveis, cidades imaginárias. Rev. Bras. Hist. v. 27, n. 53, jan./jun. 2007.

SOUSA, Rosana de Fátima Padilha de. Reduto de São José: história e memória de um bairro operário (1920-1940). Dissertação (Mestrado) - Universidade Federal do Pará, Programa de Pós-Graduação em História Social da Amazônia, Belém, 2009. 


\section{AS CRÔNICAS DE ENEIDA DE MORAES - JORNALISMO POLITICO ATRAVESSADO PELO TESTEMUNHO LITERARIO}

Mirna Lúcia Araujo de Moraes $^{54}$ Vera Maria Segurado Pimentel ${ }^{55}$

54 Doutora em Comunicação, Linguagem e cultura. Facilitadora do Projeto Sala de Leitura SEDUC/PA. Membro do Grupo Interdisciplinar de Textos Amazônicos-GITA-UNAMA. mguapindaia. mm@gmail.com.

55 Doutoranda em Comunicação, Linguagem e Cultura-PPGCLC UNAMA. Profa.Adjunta da Universidade da Amazônia. pimentel_106@hotmail.com 


\section{INTRODUÇÃO}

As crônicas de Eneida de Moraes apresentam-se em um período em que a imprensa dialoga com o Estado com o objetivo de usar a notícia, de acordo com os interesses dos grupos de poder, como fora observado em algumas páginas históricas do século XX; paralelo a esses jogos de interesse, essa escritora e jornalista paraense surge com um estilo jornalístico de resistência, construído por meio de uma escrita revolucionária, porque avessa às ideias capciosas postas em circulação, como, citando caso análogo, o que era "permitido" divulgar tanto na década de 30- Estado Novo -, como também pôde ser escrito na década de 60 -durante a Ditadura cívico militar.

Com isso, este artigo tem por objetivo identificar o texto de Eneida como jornalismo literário com base na teoria de Felipe Pena (2018), ao incluir a imprensa na arte literária, com propósitos diferenciados dos gêneros anteriores, visto que não apresenta características ficcionais, já que o debate irradiado por essa nova forma de escrita e de estilo irrompe das relações humanas, do acontecimento em processo de discussão, no calor das interpretações do contexto manifesto como afirma o escritor:

Mas foi no começo do século XX que se instalou uma verdadeira revolução no conceito de gênero, quando as questões romperam os limites do texto e passaram a se localizar na linguagem. Os teóricos conhecidos como formalistas russos enfocaram o romance no âmbito da diversidade, como um gênero que muda de forma constantemente e é impossível de ser analisado fora do sistema onde está inserido. Para além do discurso literário, as classificações começaram a se referir a qualquer tipo de enunciado, dos mais simples aos mais complexos" (PENA,2018, p.20).

Para fundamentar essa discussão utilizou-se como procedimento metodológico a pesquisa bibliográfica dos discursos políticos entre 1930 a 1945, quando a imprensa viveu situações antitéticas, conjugado à análise das crônicas escritas por Eneida referentes a esse mesmo período. Se, por um lado, os jornalistas eram perseguidos por fatores condicionados à censura, ou pela instalação de um aparato burocrático-repressor, o departamento de Imprensa e Propaganda - DIP. Com a instalação desse órgão criado pelo governo em 1939,

“... todos os serviços de propaganda e publicidade dos ministérios, departamentos e estabelecimentos da administração pública federal e entidades 
autárquicas passaram a ser executados com exclusividade pelo órgão, que também organizava e dirigia as homenagens a Vargas, constituindo o grande instrumento de promoção pessoal do chefe de governo, de sua família e das autoridades em geral." (cpdoc.fgv.br)

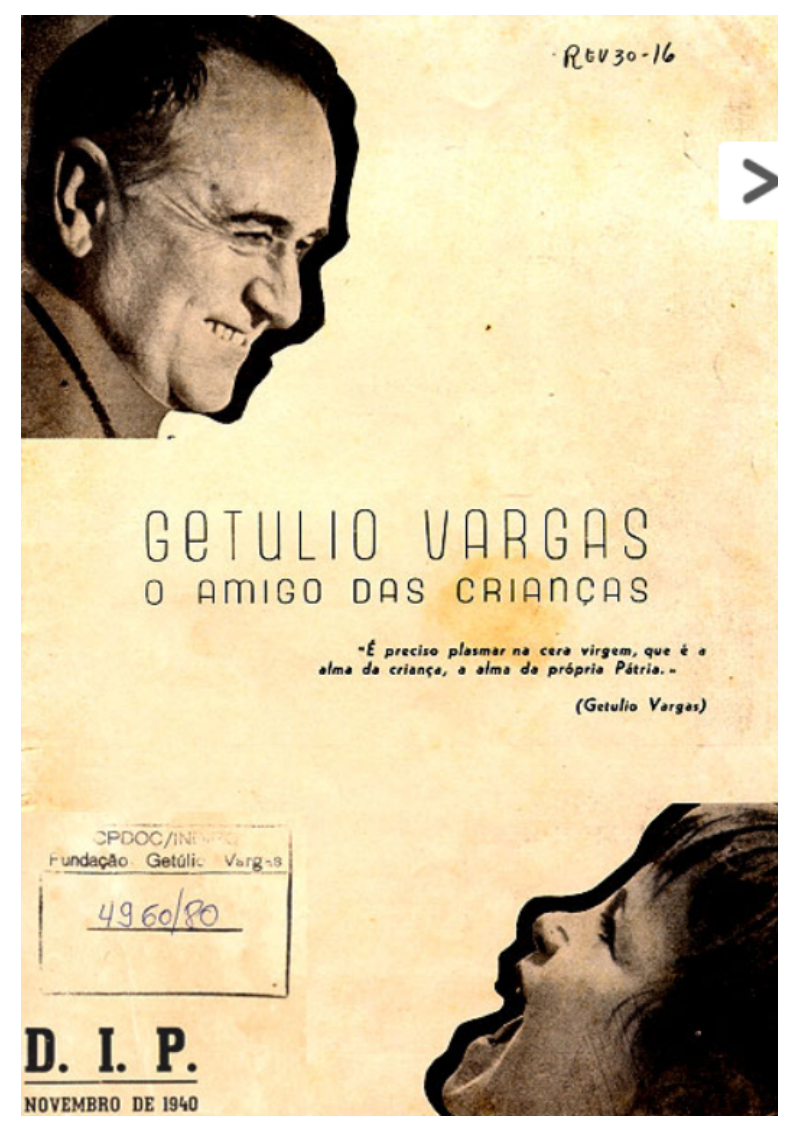

FONTE: (Getúlio Vargas, o amigo das crianças, publicado pelo DIP em novembro de de 1940. REV.30 16 f/CPDOC)

Por outro, os jornais, principalmente a imprensa do Rio de Janeiro, assumem um lugar de poder, dada à divulgação de temas sociais e políticos de apoio institucional ao governo, com isso, silenciando algumas vozes do público-leitor e consagrando o posicionamento do Estado, como visto durante os 15 anos do governo de Vargas. Barbosa (2007, p.110) aponta que:

"No Estado Novo, o pilar para a construção de um projeto de identidade nacional foi a inclusão, via formulação discursiva e ideológica, do grupo urbano em maior crescimento nas cidades: os trabalhadores. $E$ também para realizar essa proposta, a ação dos meios de comunicação é decisiva"

Barbosa também afirma:

"Podemos dizer que a proliferação de novos tipos de conteúdo na mídia do período diz respeito a uma exigência do público que procurará cada vez mais na fantasia e na emoção de rostos mitificados a expressão de seu rosto silenciado. Ao se ver apartado da discussão política, mostrará a sua face 
Vale enfatizar que Eneida, após 11 prisões, desenvolveu atividade jornalística tanto n'O Diário Carioca, como correspondente de Paris, em 1949, como também foi jornalista n'O Diário de Notícias, em 1951. Ambos sofreram a ação da censura por não aderirem ao regime, isto é, apoiavam a Revolução de 1930. Orlando Dantas, diretor proprietário do Diário de Notícias foi preso à época de Vargas, enquanto a sede do Diário Carioca foi destruída pelos soldados armados de sabres e fuzis do I regimento de Infantaria (BARBOSA, 2007).

Os fatos relatados por Eneida legitimam um tempo vivido por ela e por outros, porque como ativista política, a narrativa dela cumpria a missão da responsabilidade social de conscientizar o leitor e/ou de lecionar o público- leitor de uma parte da história, sob a ótica de quem viveu os episódios e os inscreveu na memória. Logo, não era a palavra do poder, como muitos avaliavam à época a imprensa, mas o contraponto desse poder.

\section{DISCUSSÃO TEÓRICA - O ESTILO INSUBORDINADO DE ENEIDA}

Constata-se a ausência de referência a Eneida, pelos críticos literários e, por conseguinte, a falta das coletâneas de textos da autora nos livros didáticos. E, a partir dessa lacuna nos estudos da literatura, é essencial que se façam reflexões que justifiquem tal fato.

Esta pesquisa arrisca-se a apontar pelo menos três motivos, subsidiada pela memória histórica da época:1- o cânone literário se configurar como machista;2- a estilística de Eneida ainda se encontrar em processo de conceituação estética;3- o imaginário social de recusa à figura política da escritora.

Primeiramente, ao se constatar o cânone literário machista tem-se como princípio norteador o fato de que por quase um século a Academia Brasileira de Letras, desde a sua criação em 20 de julho de 1897, ter sido frequentada por integrantes homens. E mais, no fato de que no Estatuto da Academia, constar que somente brasileiros com obras de reconhecido mérito poderiam concorrer a uma de suas 40 cadeiras. 


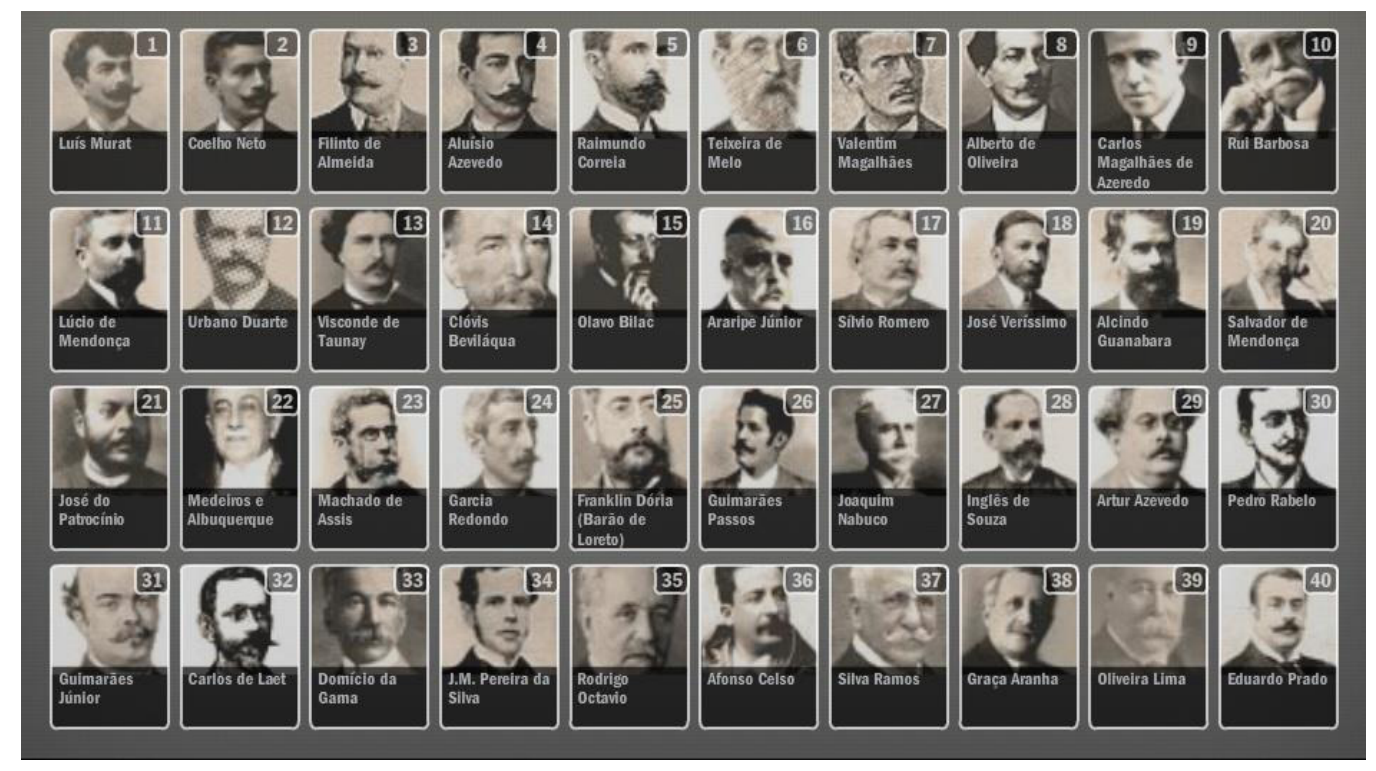

FONTE: (Diário do Contista)

Ao se referir aos brasileiros ficava legitimado no entendimento dos membros imortais dessa instituição a presença efetiva dos homens, porque essa foi a intenção daqueles que produziram tal documento. E essa intencionalidade tornou-se explícita quando em 1930 uma mulher candidatou-se para ocupar uma das cadeiras da Academia Brasileira de Letras.

Quando ocorreu a candidatura da primeira mulher à academia em 1930- Amélia Beviláquia e da segunda mulher- Dinah Silveira Queiroz- essas foram recusadas, porque no entendimento dos membros da instituição o termo brasileiros referia-se apenas ao sexo masculino. Esse fato levou à mudança do Art.30 do Regimento Interno na década de 50, ratificando a impossibilidade do acesso feminino com o ajuste no conteúdo do texto para "os membros efetivos serão eleitos, dentre os brasileiros, do sexo masculino.

Nesse momento, após discussões acerca de tal interpretação apresentada pela $A B L$ sobre a inelegibilidade feminina fica materializado o caráter misógino de seus membros, assim como a legitimação do desrespeito às mulheres e às suas produções literárias, contrariando inclusive ao disposto na finalidade de tal Academia, no Art. $1^{\circ}$. de seu Estatuto. Datado em 28 de janeiro de 1897 e assinado por Machado de Assis (Presidente), Joaquim Nabuco (Secretário Geral), Rodrigo Octávio (Primeiro-secretário), Silva Ramos (Segundo-secretário), Inglês de Sousa (Tesoureiro):

"A Academia Brasileira de Letras, com sede no Rio de Janeiro, tem por fim a 
cultura da língua e da literatura nacional, e funcionará de acordo com as normas estabelecidas em seu Regimento Interno."

Apenas em 1977 foi permitida a entrada de mulheres entre os imortais, após incansável luta e discussões do escritor Oswaldo Orico pela alteração do Art. $2^{\circ}$. do Estatuto e assegurar a imortalidade literária feminina; cabendo a uma descendente de José de Alencar, a cearense Raquel de Queiroz tal conquista.

Mesmo possuindo talento para ocupar a cadeira que desocupara com a morte de Cândido Mota Filho, sofreu preconceito intelectual, desde a publicação de sua obra O Quinze, ao ser vítima de comentários machistas de Graciliano Ramos, ao dizer:

“Uma garota assim fazer romance! Deve ser pseudônimo de sujeito barbado".

A aceitação pela $A B L$ da candidatura de Raquel de Queiroz, bem como sua vitória sobre Pontes de Miranda para ocupar a cadeira 5, anteriormente ocupada por Cândido Mota Filho foi também motivo de sérias especulações à época, tendo em vista alguns comentários sobre a conveniência da presença da escritora por questões de privilégios políticos -sociais e ser "politicamente influente, que mantinha laços estreitos com muitos acadêmicos (FANINI).

A presença feminina tardia nas instituições ligadas à memória intelectual se estendeu a outras casas literárias, a exemplo da Academia Paraense de Letras, fundada em 3 de maio de 1900 e somente treze anos depois recebeu o diploma a primeira mulher Guili Furtado, incorporada aos associados em 10 de agosto de 1913, em solenidade presidida por Luiz Barreiros.

Outra situação que causa estranhamento, além é claro de questionamentos é o fato de Eneida de Moraes não ter ocupado uma cadeira nessa entidade- APL_, já que sempre foi a própria representação e divulgadora da literatura e da cultura popular paraense, elementos integradores e potencializados em suas crônicas. Como ainda foi ela a elaboradora do Museu da Imagem e do Som, espaço paraense de preservação da memória do Estado do Pará.

O segundo fator da possível omissão em relação ao estilo de Eneida para o público- leitor, vem em parte como consequência do anterior, além de concentrar-se na falta de elementos ou de critérios necessários que alcançassem o seu estilo de escrita inovador tanto no conteúdo quanto na estética. Inovador, por apresentar es- 
tratégias de proximidade com o leitor/ a leitora, pelo tom de relato do vivido também documentado com a finalidade de contar o não contado. Revolucionário também por fundir dois gêneros narrativos distintos, como a crônica - um texto reflexivo extraído do cotidiano, com um discurso polêmico como a notícia.

Essa, mesmo mantendo a linguagem clara e formal, se ressignifica pelo olhar contextual da jornalista com o tom de um relato de memórias, a partir do lugar autoral de enunciação. Não apenas relembra fatos e pessoas importantes em sua vida, mas de fatos importantes da memória nacional.

O estilo de escrita de Eneida traz o tom da resistência, das novas configurações políticas que acarretaram transformações culturais, como a já citada urbanidade modificada na então capital do país, Rio de Janeiro, seguindo as características de um grande centro europeu- Paris.

E, por último, o fator da atuação política da escritora. Característica essa inaceitável para alguns vetores sociais, como por exemplo, alguns representantes da imprensa que, por se assumirem simpáticos ao poder estatal, através da veiculação de notícias de completo apoio ao governo, também ficariam imunes da ação autoritária de alguns órgãos burocráticos- repressores como o DIP- Departamento de Imprensa e Propaganda, criado em 1930. E, mais tarde, o DPDC- Departamento de Propaganda e Difusão Cultural, criado em julho de 1934.

Ressalte-se que:

"o DIP exercia um duplo controle: um controle autoritário proibitivo, da censura propriamente dita. E tinha o controle através da corrupção. O caso da isenção para a importação do papel da imprensa" (BARBOSA, 2007, p. 111).

Já o DPDC- Departamento de Propaganda e Difusão Cultural, também criado na Era Vargas era "ligado ao Ministério da Justiça, retirando do Ministério da Educação o controle da propaganda, do rádio e do cinema."

Em meio a esse cenário Eneida se movimentava e escrevia com atitudes opostas ao governo. Mais uma expressão inteligível que justifica a inobservância e/ ou a ausência de visibilidade à obra de Eneida, mesmo que apresentada com criatividade e inovação.

Porém, como oponente do governo, cujas verbas oficiais sustentavam jornais, revistas, agências de notícias, emissoras de rádio (BARBOSA,2007). Não comporia

\section{3}


a lista dos textos canonizados. Ou seja, a produção discursiva da imprensa era vigiada e, punidos os jornais não partidários ao regime desse período.

Logo, interpreta-se que, o estilo textual bem como o seu conteúdo refletia a atmosfera combativa e combatente de Eneida e a sua maturidade intelectual, levantando debates em espaços públicos, em encontros políticos, em seus estudos sobre a cultura brasileira, em suas viagens pelo exterior como representante da Associação dos Escritores, elementos responsáveis por sua não inserção no grupo de visibilidade literária.

Vê-se que a inserção do texto de Eneida nos livros didáticos causaria também uma inconformidade com os discursos do século XXI, visto que, a atualidade do conteúdo da escritora contrariaria os tempos de retrocesso histórico vividos no Brasil, cujos direitos assegurados por uma Carta Magna com 31 anos de vigência e, mesmo assim subestimados e postos à prova para análise, a exemplo dos estudos da ideologia de gêneros por incomodar e questionar categorias fixas e polarizadas,

A leitura do texto de Eneida no Ensino Médio, por exemplo, seria uma ameaça. Ameaça, por colocar em xeque o que apregoa a Constituição Federal de 1988 em seus princípios fundamentais de que trata os artigos $1^{\circ}$. e $4^{\circ}$, ao falar de cidadania, de dignidade da pessoa humana, da livre iniciativa e dos valores sociais do trabalho. Ainda ameaça porque colocaria em dúvida a Lei de Diretrizes e Bases da Educação 9394/96 em seu artigo $1^{\circ}$. quando aborda sobre os processos formativos nas instituições de ensino e pesquisa, nos movimentos sociais, nas manifestações culturais. Fatos esses atualmente prejudicados por uma política de conveniências.

\section{ANÁLISE dOS DADOS - A NARRATIVA NA PONTA DA ESTRELA}

Sabe-se que a expressão jornalismo-literário não apresenta um conceito acabado e isso ocorre dada a complexidade que se encerra no próprio nome, em virtude do surgimento de um gênero a partir da combinação de outros dois: o gênero literário e o gênero jornalístico.

E como mencionado anteriormente, em cada um desses gêneros, vistos isoladamente, inúmeras particularidades/ nuances se consolidam, com forma, finalidade e conteúdos distintos. E, mais, acrescenta-se às peculiaridades o lugar de produção, o lugar de onde a comunicação se estabelece.

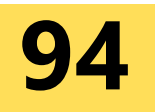


Como se pode perceber não significa uma mera integração estética. Sabe-se que, desde o surgimento do termo, houve dificuldades de conceituação, demorando dois séculos para chegar a um consenso pelos estudiosos da área da Comunicação. E, ainda assim existem dissenções.

Para Monica Martinez (2017), estudiosa há 25 anos sobre o tema, a maior riqueza da investigação dessa área encontra-se na possibilidade de se ouvir uma multiplicidade de vozes. Vozes essas que nos conduzem para a questão cultural a que todos estamos sujeitos porque atravessados por ela e como sujeitos de cultura, também influenciados por ela.

Essa pesquisadora do mesmo modo, associa a dificuldade de conceituar o jornalismo literário às complicações no estabelecimento da área de comunicação no Brasil. Ou seja, o processo histórico, que destaca a:

“Implantação de gráficas na então colônia portuguesa só seria autorizada em 1808 com a chegada ao Rio de Janeiro da corte lusitana em sua fuga das invasões napoleônicas" (MARTINEZ, 2017)

Para Mello (2015), somente nas primeiras décadas do século XX, os estudos sobre Comunicação como campo de pesquisa foram consolidados no Brasil. Portanto, os estudos sobre jornalismo literário iniciaram-se no Brasil de forma tardia. Esse novo gênero, no Brasil, apresentou grande avanço com a prática realizada pelos jornalistas da Revista Realidade, do grupo Abril. Esse grupo influenciado pelo movimento New Journalism, vindo dos Estados Unidos entre as décadas de 60-70.

Para Pena (2018), o jornalismo literário enveredou por caminhos, por conceitos, por ideias de diversas tendências quanto ao estilo, como também quanto às classificações dadas a esse novo gênero, porém adverte que nenhuma é absoluta e que todas auxiliam para o estudo, assim como a pesquisa sobre o tema.

Em meio às considerações, os estudos, as possibilidades apontadas pelos pesquisadores da área da Comunicação sobre o jornalismo literário como um gênero ainda em construção, foi provavelmente a estrela apresentada pelo professor e jornalista Felipe Pena (2018) que esclareceu alguns elementos já identificados como característicos desse estilo de escrita.

Pena reuniu tais características no que ele denominou de Estrela de Sete Pontas. Estrela a qual apresenta de maneira clara e objetiva sete pontos significativos 
que deverão constar numa narrativa para que essa seja classificada como pertencente ao Jornalismo Literário.

Se o estilo adotado por Eneida é inovador, produzido tempos antes da constituição do gênero com características próximas a sua escrita, possivelmente, os textos de Eneida são pioneiros dentro do Jornalismo Literário.

Essa afirmativa foi constatada a partir do entrecruzamento de fragmentos de narrativas de Eneida - jornalista e escritora - dialogando com elementos constitutivos da Estrela de Sete Pontas. Nesse ato conjugado de relações entre literatura e jornalismo, sem sobreposições de estilo, quem ganha em aprendizagem é o público leitor, ao verificar as possibilidades textuais enunciadas pelas narrativas.

A primeira ponta ao se referir a potencialização dos recursos jornalísticos manifesta-se no seguinte fragmento:

"-Não. Não é assim que se convence uma menina. Quando aprenderão os adultos a falar com os pequeninos? (...)

Que tenho eu a ver com aquela mãe autoritária que não conheço? Por que terei de sofrer com a pequenina que nunca vi? Por que terei de viver sempre assim, vivendo a vida de outros? Deixo ambas entregues ao desentendimento e caminho acompanhada pelo desejo, a vontade, a necessidade de acordar um trecho de meu passado onde haja um ou vários vestidos"

(Promessa em Azul e Branco, p. 29)

Nota-se um fluxo de consciência da escritora ao detectar uma ação alheia a sua vontade, ao mesmo tempo em que leva o leitor interlocutor a pensar, a refletir sobre uma questão bem maior que é a formação de uma criança, da força manifesta do autoritarismo dos pais. Além da impossibilidade da narradora de ser indiferente à cena porque num exercício de memória se projetou para o lugar daquela menina em dada época.

A segunda ponta refere-se a ultrapassar os limites do acontecimento cotidiano. Acontecimento enfatizado pelo trecho:

"Por que sou capaz de relembrar assim fatos de épocas longínquas? Por que a qualquer momento uma estória qualquer se presta à ressurreição de atos, vozes, gestos e até mesmo olhos, narizes, cabelos, mãos, coisas que nenhum retrato guardou e que tomaram parte ativa na minha vida passada?

(Promessa em Azul e Branco, p.30) 
O feminismo em Eneida traduz-se em atos de integração entre homens e muIheres, o que já demonstra uma perspectiva diferenciada em relação às ondas feministas do tempo em que viveu e uma perspectiva atualizada sobre o estudo de gênero que sinaliza para um movimento humano.

A terceira ponta enfatiza proporcionar uma visão ampla da realidade, possível de se entrever em:

"Depois outra carta: "Agora que tua avó morreu e estás uma mocinha, podes continuar ou não respeitando a promessa da cor de teus vestidos. Teus quinze anos não chegaram, mas isso não importa; teus raciocínios já estão em condições de te fazer resolver sozinha." (Promessa em Azul e Branco, p. 36)

Esse trecho de uma carta da mãe de Eneida presente nessa crônica enfatiza a cumplicidade entre mulheres, lembra também o posicionamento de bell hooks (2018) ao destacar o slogan "A sororidade é poderosa". Assim como a todo momento a escritora traz à reflexão no seu ato de escrita uma atitude de escuta, de atenção, de luta pela emancipação do pensamento humano, que deve se iniciar no ato de comunicação de cada um para vir a se tornar, mais tarde, numa ação coletiva de direitos fundamentais.

A quarta ponta faz alusão ao exercício de cidadania e tal ato implica uma atitude política, essa observada no trecho:

"- Camarada, minha camarada!

O olhar com que agora envolvia as vinte e cinco mulheres era diferente; queria entender as palavras nas paredes, perguntava, sorria, abraçava todas, chorava e ria(...) A Polícia Especial a maltratara monstruosamente. (...) Colocavam-na no alto da escada, amarrada e nua para forçá-la a declarar ou delatar, enquanto dois homens enormes Ihe puxavam os seios" ( Companheiras)

Os fatores da vida política enfatizados por Eneida e as consequências assumidas por quem fez tal opção clamam por intervenções imediatas, como ainda, por uma rede protetiva às mulheres e aos homens em atuação por um bem maior, ou seja, a possibilidade de reagir aos desmandos e/ ou abusos de poder.

A quinta ponta faz alusão à ruptura com as correntes do lead e aplicar técnicas literárias de construção narrativa.

"Quando partiu, deixava vinte e cinco amigas. Não lhe dissemos adeus, não tivemos um momento de fraqueza. Mas quando as grades se fecharam atrás 
Três meses depois ela voltou. Veio viver conosco. Todas as noites, à meia-noite, levantava-se e andava de um lado para outro, sem uma palavra (...) ficou-lhe uma psicose." ( Companheiras)

Com esse fragmento o alerta aos tempos de tortura que não se encerram no ato físico apenas. Manifestam-se em sequelas que perduraram por uma vida toda e a necessidade de instrumentos jurídicos constituídos no Brasil, tempos depois, a exemplo da Declaração Universal do Direitos Humanos como forma de coibir toda espécie de violências contra homens, mulheres, crianças.

A sexta ponta salienta a criação de alternativas para ouvir o cidadão comum, a fonte anônima, os pontos de vista que nunca foram ouvidos. Característica essa contemplada em todo o texto Baile dos Pierrôs, como o trecho a seguir:

"O Baile dos Pierrôs- tudo começou quando, iniciei estudos para a História do Carnaval Carioca(...)O Baile dos Artistas que começara com artistas de verdade, acabara sendo de todo o mundo (...) O último foi em 1968, na Sucata $(\ldots) "$

O texto de Eneida configura-se como uma provocação ao público-leitor quando enfatiza no conteúdo deste pistas, marcas, registros de um período, a exemplo de 1968, pontuado por incertezas, por revoltas em todos os setores. Período de lutas por transformação de mentalidades.

A sétima ponta chama a atenção para a perenidade do texto que influencia o imaginário coletivo e individual em diferentes contextos históricos, observado em todos os textos de Eneida e para ilustração, o trecho extraído também da crônica Companheiras

"Essa mulher se chamava Elisa Soborovsk, a Sabo Berguer, mulher de Henry Berger. O governo Getúlio Vargas entregou-a mais tarde à Gestapo. Hitler matou-a.

$\mathrm{Na}$ noite em que ela partiu com Olga Benário para o navio que as levaria a Hitler, era inverno e tiritávamos de frio(...)"

A citação dos nomes dessas mulheres ativa a memória dos interlocutores, não somente para a barbárie sofrida por elas, mas para os horrores dos campos de concentração e que boa parte de leitores volta a atenção para o Dachau, construído em 1933 para receber comunistas e social-democratas. Mais tarde, foi usado contra deficientes físicos e mentais e, posteriormente, para o extermínio de judeus. 


\section{CONSIDERAÇÕES FINAIS}

A insubordinação constante no espírito de Eneida atravessou o seu texto. Foi materializado por meio de um estilo de escrita diferenciado e, essas singularidades linguísticas, possivelmente não comuns em textos do período correspondente à produção da escritora, tornaram-se fatores impeditivos para os critérios dos juízes literários

Neste momento, nem a Crítica soube dizer ao certo quais tendências eram predominantes no texto da versátil escritora, visto que Eneida desafiou os rótulos, as classificações, exatamente porque seu estilo nasce com ela. Para melhor entendimento, sua natureza estilística inscreve-se e estrutura-se no momento do acontecimento, no instante das tensões sociais, na interpretação de uma nova condição cultural, no protesto das mudanças, na sofreguidão humana pela escuta de vozes sufocadas por um tempo "quase" infindo dos movimentos de libertação dos oprimidos, da descolonização de atitudes nacionais.

Em meio aos confrontos vividos pela escritora, ela captura o tempo- instante, o tempo- agora e os documenta, numa escrita de si e de outros. Uma escrita sem o vitimismo heroico, com uma escolha vocabular que em nada transfere para o público-leitor tristeza ou arrependimento.

Pelo contrário, no conjunto dos textos por ela produzido, um conteúdo revelador de múltiplas vozes se espraiando por entre as linhas, por entre as páginas das crônicas, evidenciando uma parte significativa da história nacional, sendo escrita / documentada no instante momento do acontecimento, ao longo do século em que a autora ousou contradizer os parâmetros de uma época.

O tom indecifrável de seu estilo, transita por entre a responsabilidade de um fazer literário com compromisso com as gerações futuras e, ao mesmo tempo, preocupada com a formação histórica deste cidadão, leitor futuro de seus textos, anos depois dos fatos ocorridos. Oportunidade ainda desses mesmos leitores conhecerem uma outra "versão" da história, contada e escrita por quem viveu o momento relatado, sem possíveis "traduções".

Essas particularidades do testemunho e, ao mesmo tempo, da notícia são características pioneiras no campo das tendências tanto literárias quanto jornalísticas. 
Por esse motivo, o que se percebe no decurso da tentativa desta pesquisa de classificar, de rotular o texto de Eneida são prováveis aproximações com movimentos políticos, sociais, culturais ocorridos simultâneos à época a que Eneida também rascunhava a história. Movimentos esses que provavelmente a afetaram, além do que, movimentos também afetados pela participação de Eneida nesses eventos.

Ao se afirmar, anteriormente, que Eneida foi uma das pioneiras na construção e/ou exercício de uma literatura vanguardista, cujo tom e estética encontram-se também presente no jornalismo, tem seu nascedouro na constatação das características de sua própria e atípica escrita para a época: a partir do viés testemunhal (escrita de si) e o compromisso do jornalismo "ideal " com a circulação da notícia sem disfarce, sem o filtro dos aparelhos ideológicos, sem os cortes dos censores.

\section{REFERÊNCIAS}

BARBOSA, Marialva. História cultural da imprensa: Brasil, 1900-2000. Rio de Janeiro: Mauad X, 2007.

HOOKS, Bell. O feminismo é para todo mundo [recurso eletrônico]; políticas arrebatadoras; tradução Ana Luiza Libânio. - 1.ed.- Rio de Janeiro: Rosa dos Tempos, 2018.

MARTINEZ, Monica. Intercom- São Paulo,v.40,n.3, p. 21-36, set./dez. 2017.

MELO, José Marques (organizador). Comunicação na América Latina- Campinas , SP : Papirus, 2015.

MORAES, Eneida. Aruanda. Belém, Secult: FCPTN, 1989.

MORAES, Mirna L.A. Eneida sem máscaras e sem mordaças: uma amazônida (in)subordinada em trânsito pelo século XX. Tese de doutorado. PPGCLC/ UNAMA, 2020.

PENA, Felipe. Jornalismo Literário,-2.ed. São Paulo: Contexto, 2018. 


\title{
JOANA D'ARC: REPRESENTAÇÕES FEMININAS NA HISTORIOGRAFIA MEDIEVAL E NA ICONOGRAFIA
}

\author{
Anna Ortiz Borges Coelho ${ }^{56}$ \\ Yasmim Carina Bastos Ribas ${ }^{57}$
}

$56 \quad$ Advogada, mestranda em Ciências Criminais pela PUCRS. Especialista em Ciências Penais pela PUCRS e atualmente graduanda em História também pela PUCRS. E-mail: annaortizborges@ gmail.com.

57 Graduanda de Ciências Sociais pela PUCRS, Letras pela UNICSUL e Biblioteconomia pela UFRGS. E-mail: yasmim.ribas@acad.pucrs.br 


\section{INTRODUÇÃO}

Neste artigo, buscaremos compreender, através de uma revisão bibliográficae análise imagética, como as representações femininas se davam na Idade Média, analisando, especialmente, a história de Joana D'arc. No período medieval, com a grande força da Igreja Católica, as sociedades ocidentais eram marcadas por fortes valores patriarcais, o que colocava as mulheres em uma relação subalternizada frente aos seus pais, maridos e irmãos.

Essa dominação masculina fazia com que diversos espaços importantes não pudessem ser ocupados por mulheres. Se dentro de casa as mulheres muitas vezes não possuíam o poder de comandar certas questões, o mundo público por sua vez mostrava-se um terreno proibido para corpos femininos. Compreender quais os lugares eram acessíveis às mulheres, e quais não eram aqui mostra-se necessário para justificar o percurso histórico que Joana D’arc percorreu durante sua vida e como isso acabou resultando na sua execução. Obviamente, essa inferiorização feminina acabou gerando resultados a longo prazo como, por exemplo, a forma como as mulheres seriam retratadas posteriormente pela própria iconografia, através de pinturas, pela historiografia e pela sociedade ocidental como um todo.

\section{0 período medieval e os corpos femininos}

O período medieval é conhecido historicamente como uma época onde os valores cristãos regiam a sociedade, mas diferentemente do que imaginamos serem os valores critãos no mundo contemporâneo, no medievo eles eram um tanto diferentes. A sociedade medieval era conhecida por ser uma sociedade firmada na base das hierarquias sociais, conhecida também como uma sociedade estratificada. Na Idade Média, as sociedades costumavam adotar o modo de produção feudal, mas o feudalismo acabou ultrapassando seu status de "modo de produção" e se tornando uma forma de sociedade, pois ele afetaria não apenas a forma como a sociedade medieval produziria seus bens de consumo, mas a forma como ela se estruturaria. (FRANCO, 2004, p. 6)

O feudalismo foi estabelecido através de um sistema baseado na servidão, no qual os trabalhadores conhecidos como servos, em troca de proteção, se dedicavam 
ao trabalho agrícola, no campesinato, em uma grande área rural com terras cultiváveis, fortes castelos, vilas, pastagens e bosques, terras estas de propriedade os senhores feudais. A sociedade feudal foi caracterizada pela intensa estratificação social, era dividida em três grupos sociais: clero, nobres e servos. O clero era responsável pela oração, pelo culto religioso e exercia uma enorme influência política sobre o povo. Já os nobres também costumavam ser chamados de senhores feudais e negociam diretamente com o rei suas terras e seu poder que vinha da força do seu exército e costuma ser recompensado com a entrega de terras pelos soberanos. Por último, os servos são a grande maioria dos camponeses que são explorados e têm que pagar "impostos", que naquele período eram chamados de modo diferente, visto que o termo imposto foi criado somente na Revolução Francesa. (LE GOFF, 2007, p. 24; LE GOFF, 2005, p. 42)

A realidade é que, apesar de existirem apesar três hierarquias sociais no período medieval, a mobilidade de uma para a outra era muito difícil. No momento do nascimento o indivíduo já estava predestinado a ser de um determinado nicho social, quem nascia servo seria servo, quem nascia senhor seria senhor, mas algumas alternativas existiam para se alterar a classe. Um servo poderia se tornar membro de algum exército, as chamadas cavalarias medievais eram uma boa forma de ascender de hierarquia para os indivíduos do gênero masculino. Além disso, existia a opção também de ingressar no clero e atingir um bom nível hierárquico dentro da igreja, mas essa também não era uma opção feminina, visto que poucas mulheres conseguiram atingir grandes cargos de poder dentro da Igreja Católica. (LE GOFF, 2007, p. 30)

A cavalaria era composta por cavaleiros nobres, onde seus principais valores costumavam ser a coragem e a honra. É interessante ressaltar que nem todos os cavaleiros estavam ali por livre e espontânea vontade, na verdade, existiam sim cavaleiros de fato, mas também existia parte da cavalaria como os lanceiros, os escudeiros, que acabavam sendo recrutados de outras formas, como por exemplo através de ordens religiosas. Além destes, também é importante dizer que homens ricos porém sem títulos de nobreza poderiam ingressar na cavalaria, mas teriam um título diferente dos demais, sendo chamados cavaleiros da espada dourada, uma clara alusão ao ouro que possuíam. (FRANCO, 2004, p. 103)

A cavalaria medieval possuía o papel de defender a igreja, logo, a cavalaria é 
formada por os chamados militares cristãos, e nesta, existia uma série de mandamentos que um bom cavaleiro deveria seguir, chamado de Código da Cavalaria. Entre estes mandamentos estavam: a defesa da Igreja, amar o seu país, defender e respeitar aqueles que estão indefesos, não ser covarde, nunca demonstrar fraqueza, devendo os cavaleiros morrerem lutando para demonstrarem sua bravura, seguir as leis de Deus, entre outros deveres. O grande reflexo desse código e da ligação estreita entre um exército de cavaleiros e a Igreja foram o surgimento de uma série de batalhas e guerras em nome de Deus, sempre defendendo uma ideia de guerra justa e de defesa dos valores cristãos através da lâmina da espada. Ao pensarmos nos grandes guerreiros do período medieval, poucas mulheres apareceram em nossas lembranças, mas uma importante personagem histórica que neste artigo investigaremos com maior profundidade foi a cavaleira Joana D'arc. (LE GOFF, 2013, p. 355)

Quanto à questão clerical, que também cerca a história de Joana, é importante ressaltar que durante a maior parte da Idade Média apenas mosteiros e igrejas no mundo cristão possuíam o acesso e o dever de defender o mundo do conhecimento, a verdade é que a maior parte da população não era alfabetizada nesse período. O vultuoso trabalho de alguns membros era a preservação e cópia de algumas obras, que incorporam o conhecimento gerado no período clássico, esse trabalho de tamanha relevância era feito pelos membros do clero. No entanto, as coisas começam a mudar com o estabelecimento do renascimento comercial e urbano, logo todo esse monopólio intelectual estabelecido pela igreja passaria por mudanças profundas. Desde o século XII, alguns agentes sociais passam a exigir algumas competências e conhecimentos apenas disponíveis nas áreas da leitura e da escrita, fazendo com que a necessidade do letramento saísse do clero. (FRANCO, 2004, p. 23)

$\mathrm{Na}$ verdade, funcionários públicos nos novos estados que se criavam e se reorganizavam deviam cuidar do preparo de documentos, o que explica essa necessidade de se criar mão de obra qualificada e letrada para estes cargos. Além disso, a burguesia fazia exigências semelhantes para calcular seus lucros, elaborar contratos e preparar minutas, aumentando a necessidade de ampliar o acesso à educação. Com isso, retirasse a exclusividade do clero de pensar e controlar importantes documentos. Apesar disso, é essencial lembrarmos que mesmo com essa ampliação ao acesso à educação as mulheres geralmente não estavam

\section{4}


incluídas. Uma das poucas mulheres a conseguirem obter no período medieval uma importante carreira clerical foi Hildegard von Bingen, que posteriormente também foi canonizada. (FRANCO, 2004, p. 23; LE GOFF, 2013, p. 165)

Em meados do século XII e XIII acontece o aparecimento das primeiras universidades, que inicialmente eram interligadas com a igreja e serviam para a formação de clérigos, após foram se especializando também na formação de leigos como médicos e advogados. Com o aumento do surgimento das universidades iniciase a possibilidade de uma carreira acadêmica (estudo como carreira), além disso com a criação dos estados modernos e o início da burocratização estatal faz-se necessária a contratação de profissionais com formação nas áreas jurídicas para girar a máquina estatal. A Revolução Científica é um movimento de ruptura e renovação dos conhecimentos medievais e conhecimentos clássicos, ou seja, é uma revolução nos campos de estudo que geram as técnicas utilizadas na Revolução Industrial. $\mathrm{Na}$ revolução científica, no séc. XVII, há a criação de um novo método, o método científico, com a dúvida metódica e a pesquisa empírica, não mais um conhecimento dogmático, verdade como verdade provisória que pode ser reformada no futuro. Enquanto no renascimento se estudava as ciências humanas, na revolução científica se estuda a filosofia natural ou filosofia mecânica que é impulsionada pelas Academias Reais e os Liceus, grandes academias que formam novo momento com sistema heliocêntrico com o sol no centro dos planetas e todas as inovações das teorias científicas. Nesse período as principais áreas aprofundadas são: física, matemática, química, botânica, medicina, óptica e astronomia. Esse início da estruturação dos campos científicos também ficou majoritariamente nas mãos de estudiosos do gênero masculino, o que justifica o por que a história de Joana D'arc, sendo uma mulher que ocupou um espaço restrito aos homens, ficou por tanto tempo encoberta no campo histórico. ( LE GOFF, 2005, p. 109; LE GOFF, 2013, p. 356)

\section{A história de Joana D’arc}

Em 1412, nasce no povoado de Domrémy-la-Pucelle a francesa Joana D'arc. A França passava por um conturbado momento histórico, não era a nação que conhecemos hoje, mas sim um amontoado de pequenos feudos, que estavam dominados pela Inglaterra. Joana D'arc nasceu bem no meio da conhecida Guerra 
dos Cem Anos, que perdurou de 1337 a 1453, considerado um dos maiores conflitos ocorridos durante a Idade Média. (CASTOR, 2018, p. 20)

O rei Carlo IV veio a falecer em 1328, sem deixar herdeiros, o que gerou uma disputa ao redor do trono Francês. O parente mais próximo do falecido rei era Eduardo III, rei da Inglaterra; o povo francês, recusando-se a ver um extrangeiro no trono do país, optou pela coroação de um primo de Carlos IV, o francês Felipe de Valois, intitulado Felipe VI. A França argumentou com uma de suas leis, a qual dizia que o rei a ocupar o trono francês teria de ser parente da monarquia francesa por parte de pai, e Eduardo III tinha o sangue real francês apenas por parte de mãe. (CASTOR, 2018, p. 41)

Apesar desse ter sido o estopim para o início da Guerra dos Cem Anos, outros motivos eram mais importantes, como por exemplo questões de territórios, comércio e cidades estratégicas. No século XIV, a Inglaterra queria controlar o território de Flandres, que era, economicamente, uma das melhores regiões da Europa e estava sob domínio francês naquele momento. (CASTOR, 2018, p. 59)

Após quase cem anos de guerra, a França estava entrando em colapso, a capital do país havia sido tomada pelos ingleses, e a derrota total dos franceses estava próxima. Nesse momento, surge uma menina de 16 anos, camponesa, que auxilia o exército francês na retomada dos territórios tomados pela Inglaterra. Joana D'arc lutou no campo de batalha e reanimou seus colegas miliares, os quais, juntos a ela, conquistaram inúmeras vitórias a partir daí. (CASTOR, 2018, p. 137)

Joana D'arc cresceu em uma época conturbada e repleta de eventos marcantes. A família de Joana era muito religiosa, e isso obviamente a influenciou; a menina, muito religiosa, começou a escutar vozes e ter algumas visões. A primeira vez em que teve essa experiência foi com treze anos. As figuras divinas com as quais Joana diz ter tido contato, queriam lhe passar a mensagem de que ela deveria integrar o exército francês. (CASTOR, 2018, p. 73)

As visões e vozes tornaram-se cada vez mais frequentes e então, em 1429, com seus 16 anos de idade, Joana D'arc resolveu se dirigir à corte do rei, na época, Carlos VII. A menina se depara com o capitão Robert de Baudricourt, e o convence a ajudá-la; ele lhe entrega um cavalo e proteção de militares que a escoltaram até o castelo. Entretanto, antes de partir, Joana cortou seu cabelo bem curto e se vestiu 
como homem, posto que não acreditava que fosse ser levada à sério se não o fizesse.

Após a conversa com o monarca, ele permitiu que ela liderasse um pequeno exército cujo objetivo era salvar a cidade de Orleáns. (CASTOR, 2018, p. 108)

Apesar do relevante papel que Joana cumpriu de elevação do sentimento nacional durante a Guerra dos Cem Anos ela acaba sendo sentenciada à morte. Joana tentou retomar a cidade de Compiègne, a qual estava sob domínio de borgonheses, isto é, de aliados ingleses. Durante tal batalha, ela acabou sendo presa e entregue aos ingleses, que objetivavam levá-la à Santa Inquisição, sendo o bispo que participou do julgamento de Joana D'arc era aliado da Inglaterra. Em 1431, Joana acabou sendo queimada na fogueira a mando do Tribunal Eclesiastico francês e inglês, sob a acusação de ser uma feiticeira e herege. (CASTOR, 2018, p. 291)

Sabe-se que Carlos VII, que tornou-se rei oficial da França justamente por conta de Joana D'arc, não interveio no processo de julgamento dela e não tentou impedir sua morte. Todavia, depois do falecimento de Joana, ele tentou fazer com que seu processo e condenação fossem anulados, visto que não ficaria bom para um rei ter sua imagem ligada à de uma mulher acusada de bruxaria.

Carlos VII, visando "resgatar" a imagem daquela que "salvou os territórios franceses" (posteriormente, Nação - França) reuniu uma documentação (somente após sua morte) visando reabilitá-la, após insistentes pedidos da mãe de Joana, Isabel Romée. (Convém lembrar que o rei francês manteve-se "isolado" durante o processo de condenação de Joana, aquela que um dia o fez coroar rei em Reims). - (CERINI, 2010, pág 73)

Carlos VII conseguiu a anulação da condenação, entretanto a real reabilitação da imagem de Joana se oficializou apenas em 1909, com sua beatificação, e em 1920, quando foi canonizada.

Os anos seguintes mostram a morte de Joana como bandeira de luta dos franceses, que após várias batalhas conseguiram a expulsão dos ingleses de seu território... era o fim da Guerra dos Cem Anos (1337-1453) - na verdade durou cento e dezesseis anos corridos, contadas as tréguas. [...] Embora Joana nunca tenha sido esquecida inteiramente, o interesse por ela só reviveu de fato no século XIX, na fase nacionalista que se seguiu à Revolução Francesa. Em 1869, o bispo de Orléans, Félix Dupanloup, deu início às gestões para obter a sua canonização. Na década de 90, Leão XIII abriu uma investigação nesse sentido. Em 1909, Joana foi beatificada (Pio X) e, em 1920, canonizada (Bento XV). - (CERINI, 2010, pág 73) 


\section{Representações de Joana D'arc}

Após um longo período de esquecimento popular a imagem de Joana D'arc acabou sendo novamente lembrada com a chegada da Revolução Francesa. A Revolução Francesa trabalhou com a ressignificação da imagem de Joana, transformando-a em uma heroína nacional. Essa modificação no significado simbólico de Joana D'arc se deu, pois no período da Revolução Francesa mostravase necessário encontrar um símbolo nacional que trabalhasse a ideia de ruptura e continuidade. Quando a revolução surge com ela vem a ideia de rompimento com um antigo regime, mas não apenas isso, a ruptura com uma antiga forma de pensar e governar a sociedade francesa. A necessidade do povo francês por esse rompimento com os valores tradicionais que comandavam a sua sociedade fizeram com que a imagem de um herói nacional se fizesse necessária. A imagem de Joana D'arc parecia servir ao interesse dos iluministas do período, era uma imagem feminina que trabalhava diretamente com a ideia de ruptura, uma mulher que rompia com ideias tradicionais, se alistava para servir na cavalaria e lutava em prol da nação francesa. Joana acaba recebendo posteriormente a pena de morte, não apenas por ser considerada uma feiticeira, mas por ser considerada uma herege, o que exautava ainda mais seu lugar contrário ao regime monárquico francês. (AMARAL, 2011.)

Apesar disso, Joana D'arc mostrava-se para muitos iluministas uma imagem controversa do que a revolução pretendia, visto sua forte ligação com o cristianismo, mesmo assim sua imagem acaba ligada ao movimento revolucionário, construindose até mesmo estátuas de Joana pela França como símbolo dos valores nacionais. Anos mais tarde, o próprio Napoleão mostra-se contente em reerguer uma estátua de Joana D'arc que havia sido destruída, demonstrando como ela era de fato a imagem de heroína que a França precisava naquele momento histórico. O nacionalismo francês mostra-se uma criação pós Revolução Francesa, e dentro dessa ideia do clamor nacional a figura de Joana D'arc demonstra a importância da criação de símbolos que unem a sociedade.(AMARAL, 2011, p. 4; DOSSE, 2001, p. 9)

Mesmo que a imagem de Joana D'arc só tenha se popularizado após a Revolução Francesa, na historiografia não podemos dizer que ela ficou totalmente apagada, visto que por muito tempo existiu a busca por fontes primárias confiáveis 
que tornassem o estudo da história da vida de Joana possíveis. Por um longo período, o estudo sobre a memória de Joana D'arc teve como principais fontes o seu processo de julgamento, que inclusive teve sua publicação impedida durante o período da Revolução Francesa com o guilhotinamento de L'Averdy. Françoise L'Averdy era um dos principais estudiosos da chamada história joanina e acabou encontrando os manuscritos do processo da execução de Joana D'arc em 1787. (AMARAL, 2011, p. 6; FURET, 1984, p. 33 )

A ressignificação imagética de Joana D'arc pode ser vista também através das diversas obras de artes que a retrataram. A primeira que analisaremos é uma iluminura ainda do período medieval, onde a figura de Joana estava diretamente interligada a seu papel como uma cavaleira que buscava proteger a fé, assim como os demais cavaleiros medievais Joana lutava em nome de Deus. (ZANIRATO, 2010, p.1)

Figura 1 - lluminura de Joana D’arc do século XV com autoria desconhecida.

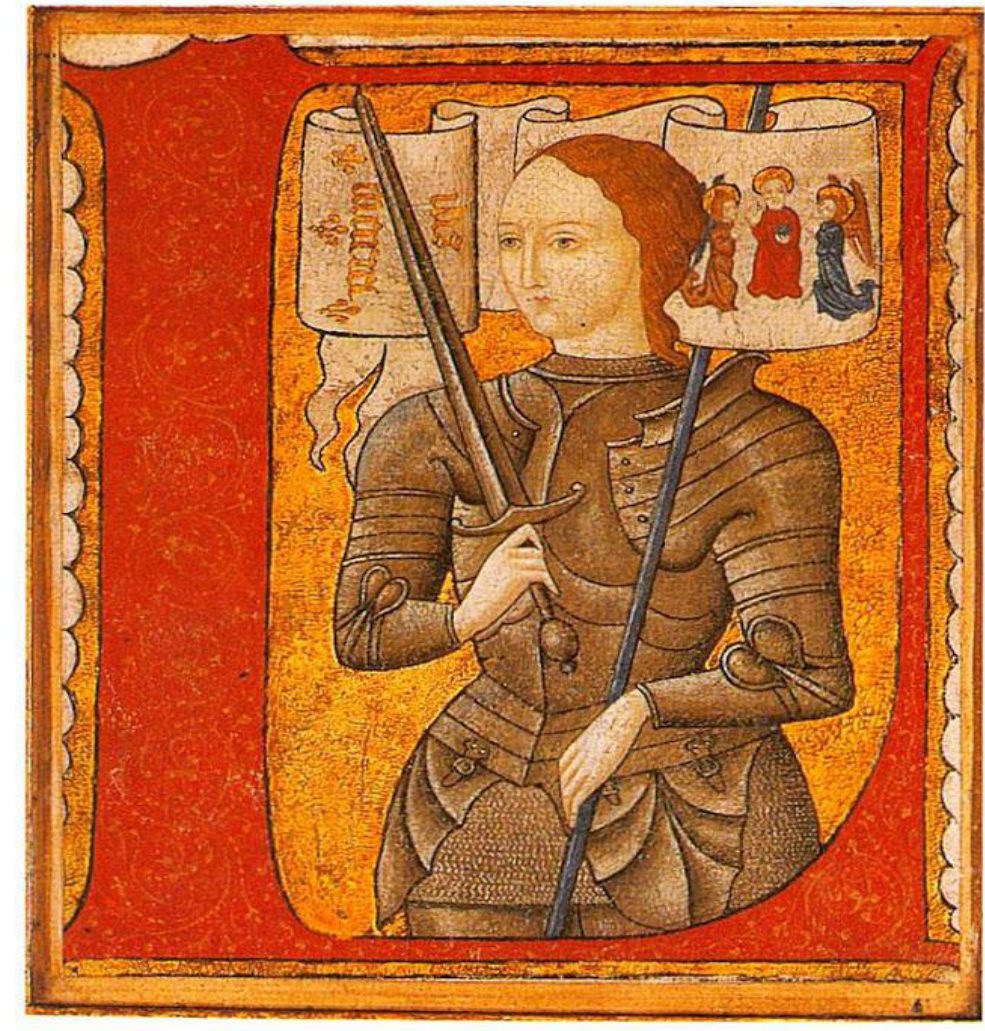

Fonte: Imagem retirada dos arquivos nacionais de Paris.

\section{9}


Nessa iluminura do século XV, Joana é representada por uma figura feminina que utiliza armadura, com mãos delicadas e cabelo claro, com uma ligação forte com o divino, Joana empunha a espada, essa era a percepção da imagem de Joana no período medieval. (Figura 1) Pouco antes da Revolução Francesa a concepção de quem era Joana D'arc mostrava sinais de desgaste, nesse período Joana era conhecida como a Donzela de Orleans, e apesar de sua ligação com o cristianismo se manter, Joana nem sempre aparece como uma guerreira. (ZANIRATO, 2010, p.2; AMARAL, 2011, p. 8)

Figura 2 - Pintura de Joana D’arc de Pedro Américo (1883)

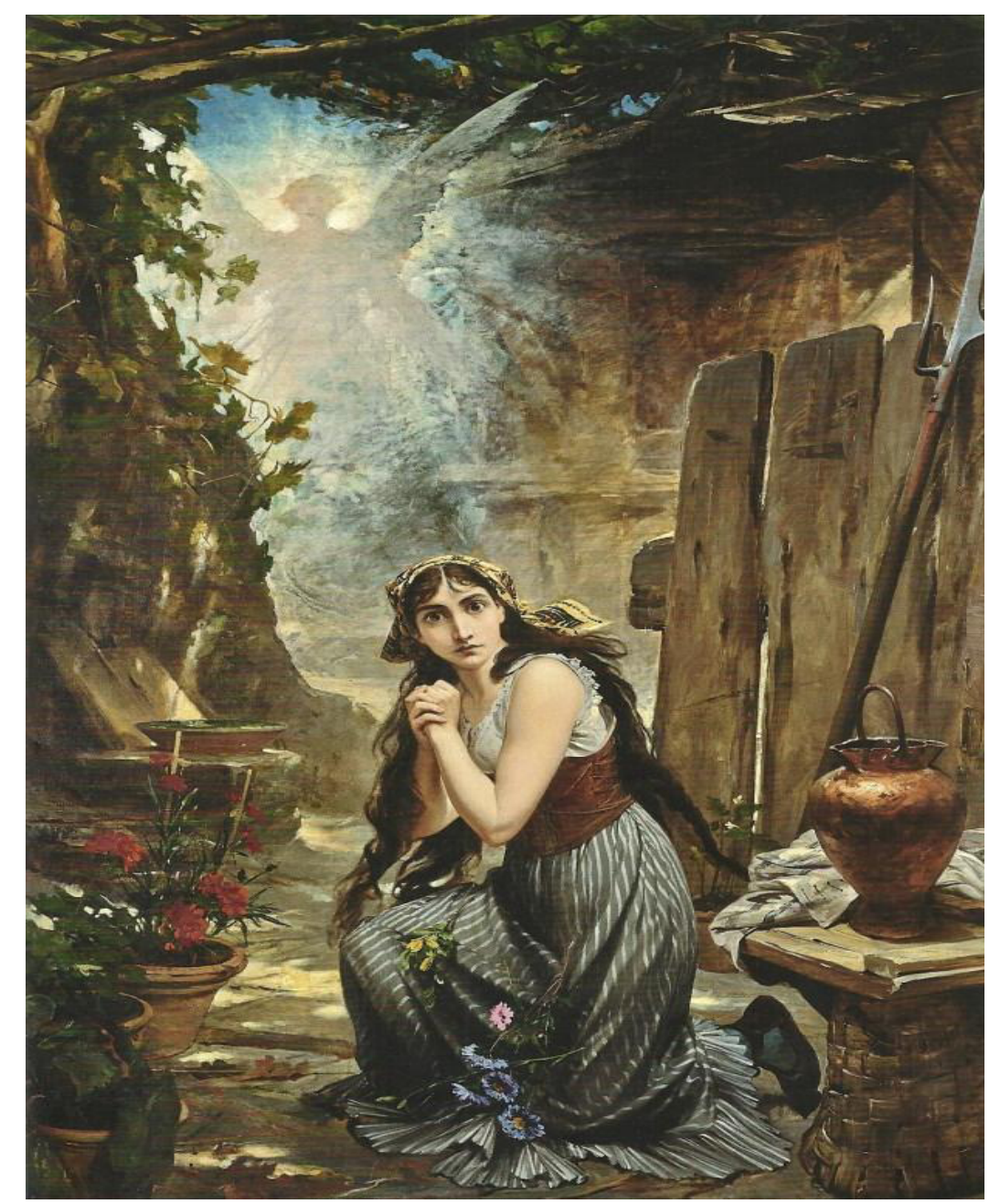

Fonte: Imagem retirada do site do Acervo do Museu Nacional de Belas-Artes do Rio de Janeiro.

Nesta pintura de Pedro Américo, Joana aparece não mais como cavaleira, mas como uma simples camponesa que recebe o chamado de Deus, ajoelhada como se estivesse rezando, de vestido, longos cabelos, Joana é retratada de forma feminina. Aqui Joana não aparece como símbolo de força, mas como símbolo da docilidade 
feminina e sua predisposição a servir ao divino. Com a chegada da Revolução Francesa e a escolha de Joana D'arc como um simbólo nacionalista francês as formas de representação joaninas também são novamente alteradas. (ZANIRATO, 2010, p.3; AMARAL, 2011, p. 10)

Joana passa a aparecer novamente como uma figura que representa a força, vestida a maioria das vezes como uma cavaleira, utilizando armaduras e empunhando a espada, mas desta vez Joana tem sua imagem afastada pouco a pouco da questão religiosa, visto que com a Revolução Francesa o elo entre Igreja e Estado acabou estremecido.

Figura 3 - Pintura de Joana D’arc por Albert Lynch (1903)

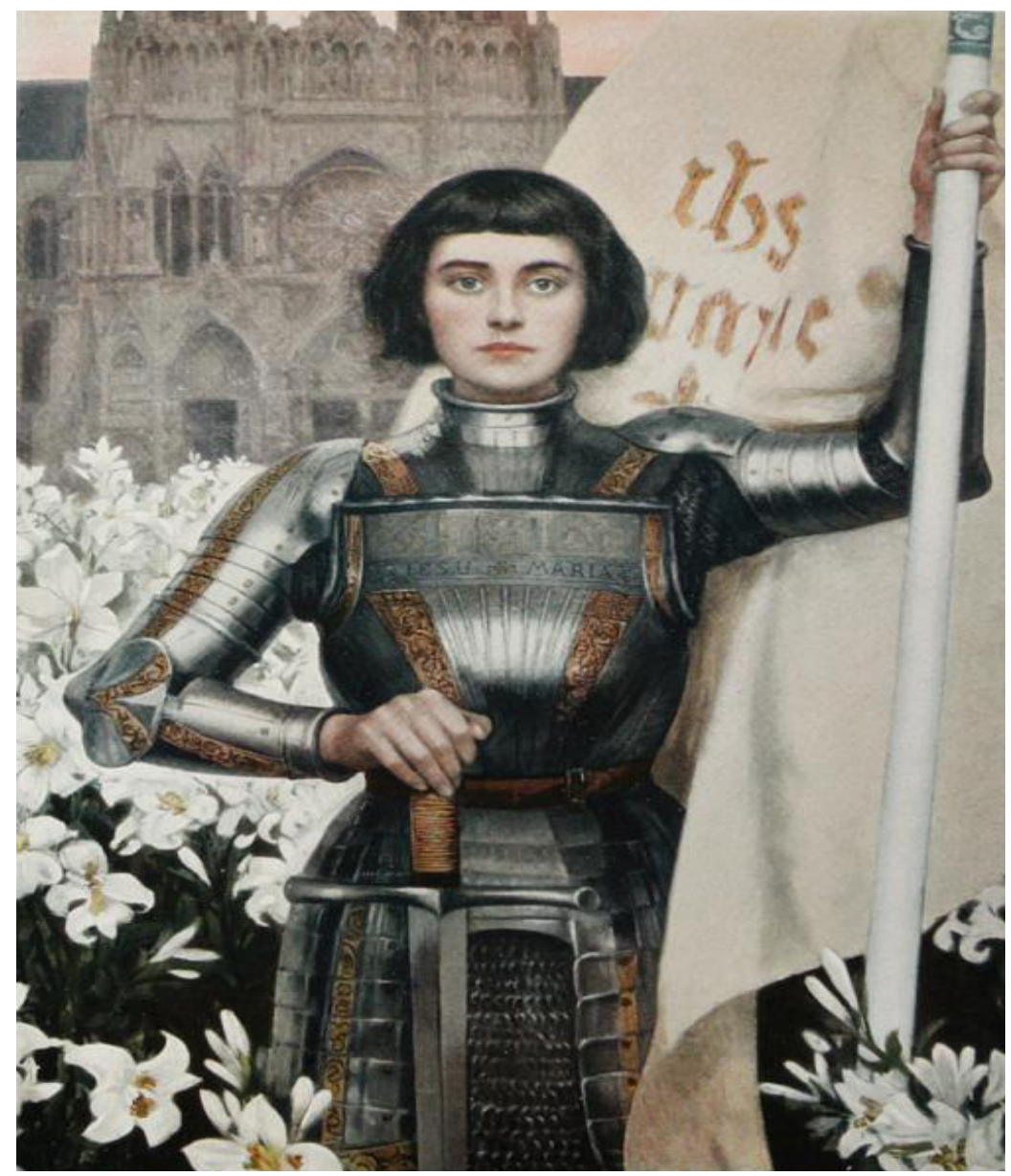

Fonte: Imagem retirada do Artrianon.

Posteriormente, as pinturas de Joana D'arc, perto do período de sua canonização acabaram se multiplicando. Ainda em 1903, o grande pintor Albert Lynch produz uma das mais conhecidas imagens de Joana para compor a capa do Le Figaro. Lynch na época já era um pintor reconhecido, e escolheu pintar Joana de armadura com sua espada, em frente a Notre Dame, catedral na qual ela seria beatificada poucos anos 
mais tarde. Joana acabou sendo beatificada em 1909, posteriormente o Vaticano acabou aceitando sua canonização que ocorreu já em 1920. (ZANIRATO, 2010, p.3; AMARAL, 2011, p. 11) (Figura 3)

\section{CONSIDERAÇÕES FINAIS}

Ante ao exposto, podemos concluir que apesar do difícil acesso das mulheres ao mundo público durante o período medieval, Joana D’arc marcou a historiografia por sua ruptura com os valores patriarcais estabelecidos no período. Joana D'arc apesar de ter tido um fim trágico, sendo condenada à fogueira, tornou-se um símbolo nacional após a Revolução Francesa. Não obstante a imagem de Joana evoluir conforme o período histórico, não podemos deixar de refletir o importante papel que ela desempenhou. Sendo uma mulher e tornando-se um símbolo nacional, sendo conhecida diretamente como uma mulher guerreira, Joana D'arc torna-se uma marca não apenas da França, mas da possibilidade da ocupação feminina de um espaço de poder e de força.

Quanto à questão de Joana D'arc na historiografia, devemos compreender que Joana não foi esquecida pelos historiadores no período anterior ao da Revolução Francesa, mas que o acesso a fontes primárias que contassem a sua história naquele tempo era escasso. Outro aspecto que justifica essa falsa percepção é que de fato as pesquisas que se relacionavam a ela por muito tempo estiveram interligadas preferencialmente a seu papel como heroína na Revolução Francesa. Logo, a ideia de que a Revolução Francesa que lançou Joana D'arc ao olhar dos historiadores mostra-se equivocada, a história joanina tem merecida relevância não apenas por Joana ser um símbolo nacional francês, mas por ser um símbolo feminino de ruptura com o que era tradicionalmente esperado e imposto das mulheres de sua época.

A imagem de Joana D'arc evolui juntamente com a história feminina, pois o momento em que Joana passa a ser vista como uma referência para o sentimento nacionalista francês é o mesmo momento histórico que as mulheres francesas passam a percorrer os primeiros passos para a autonomia política feminina. A Revolução Francesa mostra-se uma verdadeira revolução social ao passo que define uma mulher guerreira como sua representante. A ressignificação imagética de Joana D’arc após Revolução Francesa é na verdade o indício de uma mudança que os papéis sociais

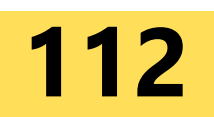


femininos logo sofreriam e que acabaria tomando conta de todo o mundo ocidental com o passar dos séculos.

\section{REFERÊNCIAS}

AMARAL, Flávia Aparecida. História, Revolução e Ressignificação: Joana d'Arc na historiografia francesa da primeira metade do século XIX. Revista do corpo discente da PPG-História da UFRGS. Num. 7, vol. 3, Fevereiro 2011.

BRESSON, Robert. O Processo de Joana D’Arc. São Paulo: É Realizações, 2011.

CASTOR, Helen. Joana d'Arc: A surpreendente história da heroína que comandou o exército francês. Belo Horizonte: Editora Gutenberg, 2018.

CERINI, Fabrício. JULGAMENTO E PROCESSO DE CONDENAÇÃO DE JOANA D'ARC: TEOLOGIA E PODER. Revista Científica das Faculdades Integradas de Jaú. SP, Num. 1, vol. 7. 2010.

DOSSE, François . A história à prova do tempo: da história em migalhas ao resgate do sentido. São Paulo : Editora da Unesp, 2001.

FRANCO JR., Hilário. A Idade Média. Nascimento do Ocidente. São Paulo: Editora Brasiliense, 2004.

FURET, François. Pensar a Revolução Francesa. Lisboa: Edições 70, 1998. A Revolução Francesa em debate. Bauru: Edusc, 2001. e "Ancien Régime". In: NORA, Pierre. Les lieux de mémoire. Paris: Galimard. 1984.

LE GOFF, Jacques, As Raízes Medievais da Europa. Rio de Janeiro: Editora Vozes, 2007. (LE GOFF, 2007, p. 24; LE GOFF, 2005, p. 42)

LE GOFF, Jacques. A Civilização do Ocidente Medieval. São Paulo: EDUSC, 2005.

LE GOFF, Jacques. Homens e Mulheres da Idade Média. São Paulo: Companhia das Letras, 2013.

ZANIRATO, Andreli de Almeida. IMAGENS DE JOANA D'ARC: IDADE MÉDIA, CULTURA E REPRESENTAÇÃO, UMA EXPERIÊNCIA DE PESQUISA, ENSINO E EXTENSÃO. Salão de Extensão. UFRGS, Porto Alegre, 2010. 


\title{
A TRAJETÓRIA DE ROSALINA COELHO LISBOA (1900-1975)
}

\author{
Yasmim Carina Bastos Ribas ${ }^{58}$ \\ Anna Ortiz Borges Coelho ${ }^{59}$
}

$58 \quad$ Graduanda de Ciências Sociais pela PUCRS, Letras pela UNICSUL e Biblioteconomia pela UFRGS. E-mail: yasmim.ribas@acad.pucrs.br.

59 Advogada, mestranda em Ciências Criminais pela PUCRS. Especialista em Ciências Penais pela PUCRS e atualmente graduanda em História também pela PUCRS. E-mail:

annaortizborges@gmail.com.

\section{4}




\section{INTRODUÇÃO}

Neste artigo, visamos desvendar a vida da poetisa, jornalista, ativista política, conhecida como Rosalina Coelho Lisboa que viveu de 1900 a 1975. A vida e obra de Rosalina, apesar da grande quantidade de fatos marcantes que a compõem, aparentemente caíram no esquecimento pela historiografia nacional.

Sua vida foi marcada por uma série de acontecimentos que andaram lado a lado com a construção política do nosso país. Rosalina era conhecida por ter sido uma grande anticomunista, por ter lutado pela Revolução de 1930 e por ter marcado o feminismo brasileiro com seu lobby pela aquisição do sufrágio feminino. A história de Rosalina pode ser vista como o clássico exemplo de dualismo entre as fortes posições políticas contrárias ao comunismo e a luta feminista. Em sua vida, vários são os momentos em que Rosalina flerta com as ideias fascistas, especialmente no período em que Vargas estava no poder, mantendo contato próximo com o presidente e seu jogo político.

A participação política feminina era amplamente defendida por Rosalina, que também militava em prol do trabalho das mulheres e da emancipação feminina de forma geral.Apesar de seu apagamento histórico, Rosalina mostrou-se uma das mais influentes personalidades políticas femininas do seu tempo. Sabemos que a maioria das ativistas feministas daquela época conseguiu pouco ou nenhum espaço para real participação político-partidária, mas Rosalina atravessou a fronteira entre os gêneros e participação do círculo intelectual proeminentemente masculino que aconselhava Vargas.

Iniciou sua vida política através dos diversos trabalhos publicados ainda na década de 20 promovendo discursos revolucionários. Seu reconhecimento por Vargas era tão grande que foi a primeira mulher a ser enviada pelo Brasil ao exterior em missão intelectual. Por isso, conhecer a biografia de Rosalina Coelho Lisboa mostrase essencial para aqueles que buscam estudar a história intelectual das mulheres brasileiras. 


\section{MÉTODO BIOGRÁFICO}

O Método Biográfico, muito utilizado em diversas pesquisas, baseia-se no uso e também na coleta de documentos que comprovem a história de vida da pessoa estudada, tanto no âmbito profissional quanto pessoal. Seu foco está centrado nas experiências de vida e, portanto, visualiza o entendimento como a chave para moldar a vida social. (SCHMIDT, 2014)

A importância dos estudos biográficos para os historiadores vai muito além de contar a mera trajetória pessoal dos seus objetos de pesquisa, mas sim de promover uma narrativa que demonstra como as vivências daquele indivíduo, que aqui é o objeto de pesquisa, influenciaram ou foram influenciadas pela história. Por isso, em todos os trabalhos historiográficos de cunho biográficos uma série de cuidados éticos são importantes para resguardar a memória dos seus biografados. (SCHMIDT, 2014)

A responsabilidade ética do método biográfico para os historiadores diz respeito ao intuito deles de promoverem os percursos históricos dos biografados, e não de desvendar segredos ou aspectos pessoais de cunho jornalístico que possam difamar a história daquela personalidade. Os biografados devem ser vistos pelo historiadores como um campo de possibilidades, para a historiografia não existem biografias definitivas, ou verdadeiras, pois a história se constitui através de diversas explicações históricas e dos diferentes olhares dos historiadores. Como explica Benito Bisso Schmidt:

Enfim, seu ponto de partida, seus métodos e seus compromissos são bem diferentes daqueles dos biógrafos jornalistas, o que não significa que seus trabalhos sejam mais ou menos importantes, mas apenas diferentes por serem produzidos em lugares sociais diferenciados. Saliento ainda que, cada vez mais, o presente é também o tempo dos historiadores (e não só dos cientistas sociais e dos jornalistas), o que repercute na produção de biografias, ou seja, muitos profissionais de História estão se voltando para as trajetórias de personagens atuais, vários deles ainda vivos, o que nos insere com força no debate atualmente travado entre os defensores e os opositores da autorização prévia das biografias. (SCHMIDT, 2014, p. 139)

As biografias, de modo geral, servem para relembrar importantes personagens históricos que acabam sendo soterrados pelos muitos acontecimentos políticos. Personagens, estes, que nem sempre são apagados de forma proposital, mas que acabam caindo no esquecimento. As biografias históricas buscam, não somente 
prestigiar seus biografados, mas trazer à tona uma série de mecanismos sociais que são tão importantes para a construção de grupos e instituições que movimentaram a história. Por isso, compreender de onde saiu aquele personagem, quais eram suas amarras, seu embasamento pessoal e teórico demonstra-se tão importante quanto observar apenas suas decisões e suas trajetórias. (SCHMIDT, 2014)

\section{A VIDA DE ROSALINDA}

Rosalina Coelho Lisboa, filha de Luzia Gabizo Lisboa e João Gonçalves Coelho Lisboa, nasceu no Rio de Janeiro no ano de 1900. Seu pai foi um importante repuplicano, deputado e senador federal, além de professor, sendo assim, não apenas pela época em que cresceu, mas também pelo meio em que se inseriu, teve sua juventude muito caracterizada por mudanças sociais e políticas no Brasil. Assim, ela participou ativamente da vida pública do Brasil, indo a Congressos favoráveis à defesa da causa feminina, além de fazer nos principais jornais da região e trocando cartas com o presidente Getúlio Vargas, cujos assuntos tratavam-se de política nacional e internacional. (SILVA, 2013).

Ela foi educada em casa por estrangeiras, tendo aos seus apenas 14 anos de idade já publicado seu primeiro soneto "A mágoa de Seringepata". Após um ano, Rosalina passou a ser uma destacável colaboradora da revista Careta. (SILVA, 2013).

Rosalina acaba se casando ainda muito jovem com o comandante Van Rademaker e ficou viúva ainda aos 19 anos, desta união tiveram uma filha. Com as grandes dificuldades econômicas oriundas da viuvez precoce, Rosalina dedicou-se intensamente ao trabalho, escrevendo para uma série de jornais e revistas da época utilizando vários pseudônimos. (SILVA, 2013)

Anos mais tarde, Rosalina casa-se novamente, desta vez com o norte-americano James Irvin Miller, que na época era vice-presidente da United Press na América do Sul. Já no início dos anos 40, Rosalina consegue anular este segundo casamento, casando-se novamente com o então empresário Antônio Sanchez de Larragoiti. 0 terceiro marido de Rosalina, Larragoiti, era um conhecido apoiador da Guerra Civil Espanhola, tendo contribuído financeiramente com os franquistas.(SILVA, 2013)

Quanto às suas vivências na vida pública, Rosalina ficou conhecida por ser uma grande entusiasta dos movimentos revolucionários dos anos 20 . Visando ajudar os 
exilados, Rosalina fixou residências por 12 anos na Argentina e escreveu defendendo a anistia para estes. Também ficou conhecida como uma defensora da Revolução de 1930. Era uma das principais personalidades políticas do gênero feminino que defendia a participação da mulher na política, além da a igualdade de direitos entre os gêneros e, é claro, o direito às mulheres ao trabalho formal. Foi convocada como representante da Paraíba no Congresso Feminino Internacional que aconteceu em 1930 no estado do Rio Grande do Sul. (SILVA, 2013)

Como forma de resistir às ideias comunista, Rosalina pregava pela importância da adoção de uma educação voltada para a moral nas escolas. Em sua vida, Rosalina pronunciou vários discursos e escreveu incontáveis artigos falando sobre a importância de formar uma frente de combate ao comunismo. Inclusive, neste mesmo período, Rosalina elaborou uma propaganda de rádio pregando em prol da revolução a pedido de Getúlio, tornando-se posteriormente a única mulher a ser responsável pela aprovação da radiodifusão ligada à educação no Brasil. (SILVA, 2013)

Figura 1

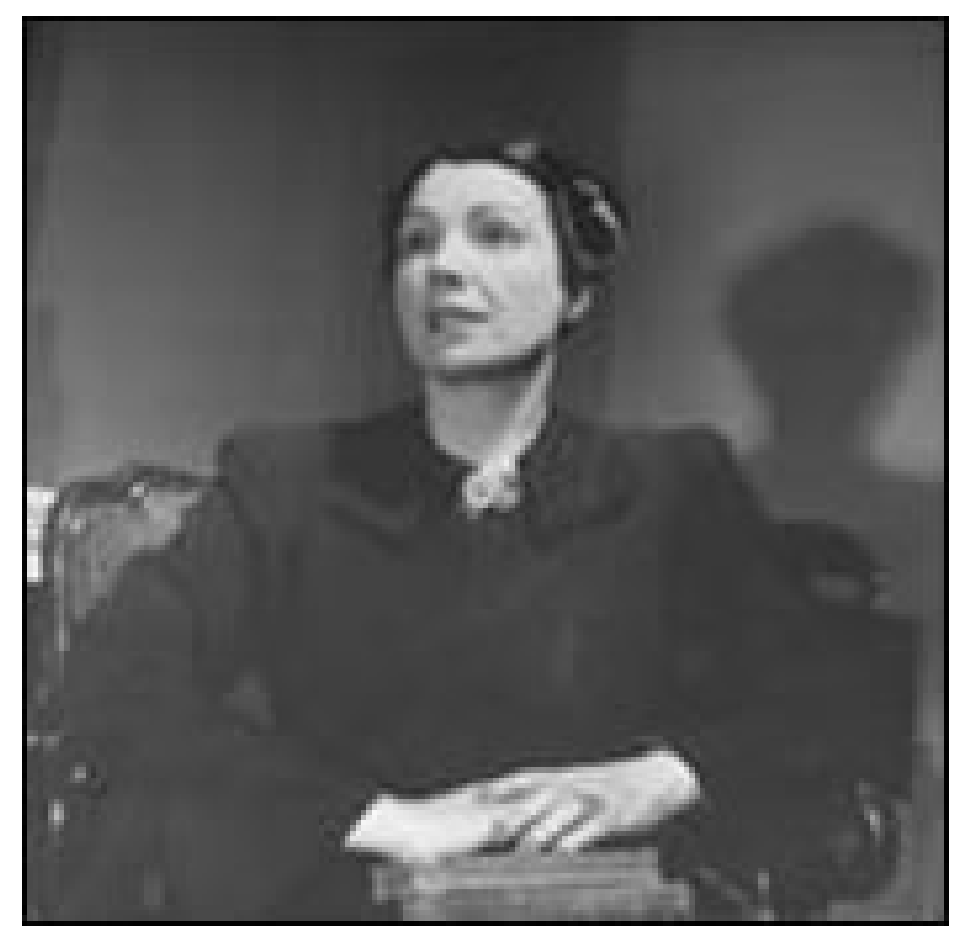

Fonte: Site Antonio Miranda

Rosalina Coelho Lisboa, em 1937, mostra-se uma importante apoiadora do golpe de Estado ocorrido no Brasil, fato que resta comprovado através do grande número de artigos em que ela escreveu sobre o assunto naquele período, além da 
vasta quantidade de cartas trocadas diretamente com Getúlio. No mesmo ano, Alzira Vargas envia a Rosalina uma carta agradecendo o apoio que ela prestava ao seu pai, garantindo a ele as articulações necessárias para que o Estado Novo fosse então implementado. (SILVA, 2013)

Anos mais tarde, a figura de Rosalina mostra-se favorável ao movimento integralista:

Adepta da Ação Integralista Brasileira (AIB), apoiou a candidatura do líder nacional Plínio Salgado às eleições presidenciais previstas para 1938. Entretanto, Vargas, disposto a manter-se na chefia da nação, entrou em entendimentos com Plínio Salgado, barganhando a participação deste nas articulações para um futuro golpe de Estado. O líder integralista, diante da promessa do presidente de dar-lhe participação no poder, aderiu à conspiração, com o apoio de uma fração da AIB. Em setembro de 1937, com a proximidade do golpe, foram estabelecidas estreitas ligações entre os integralistas que apoiavam a solução continuísta e Vargas. Um dos principais mediadores entre a AIB e o Catete, era Rosalina Coelho Lisboa. Após o advento do Estado Novo (10/11/1937), os integralistas perceberam que suas reivindicações não seriam atendidas. Nessa ocasião, Rosalina serviu de emissária entre Plínio Salgado e Vargas, embora tenham sido inúteis suas tentativas de conciliação. Em decorrência disso, os integralistas romperam com o governo e prepararam os mal sucedidos levantes de março e maio de 1938. Embora Plínio Salgado tivesse comprovado que não participou dos levantes, Getúlio resolveu exilá-lo em Portugal, onde poderia controlar seus movimentos. Plínio passou a só lançar manifestos e tomar atitudes após consultar Vargas, tendo como intermediários nessas consultas e pedidos Gustavo Barroso e Rosalina Coelho Lisboa. (FVG. CPDOC)

Em 1951, apoiadora do divórcio, Rosalina fez campanha apoiando o senador Nélson Carneiro em seu projeto de lei que beneficiaria e muito as mulheres. Já no segundo governo de Vargas, Rosalina tem um afastamento das funções políticas, talvez por discordância com a política externa estabelecida por ele, apesar de se mostrar favorável à política internacional de seu governo. Já em 1952, Rosalina defende a liberdade de imprensa apoiando o jornalista carioca Carlos Lacerda que estaria sofrendo represália de Vargas.(SILVA, 2013)

Já em 1954, Rosalina foi eleita para um importante cargo no Instituto Brasileiro de Relações Internacionais, tornando-se, então, membro do conselho consultivo. Pouco tempo depois o nome de Rosalina surge nas manchetes como uma possível candidata ao senado através do Partido Social Progressista (PSP), mas ela se negou a concorrer. A trajetória de Rosalina Coelho Lisboa encerra-se em 13 de dezembro de 1975 no Rio de Janeiro. (SILVA, 2013) 
Mesmo na contemporaneidade, não há muitas pesquisas relacionadas a essa importante figura histórica que foi Rosalinda, a qual influenciou consideravelmente Vargas.

Sua trajetória de vida e seus feitos passaram despercebidos pelo discurso historiográfico. Amiga de Vargas, Rosalina imprimia, silenciosamente, sua marca nas políticas interna e externa durante as décadas de 30 e 40. Correspondia-se assiduamente com Vargas, sempre o aconselhando acerca das melhores medidas a serem adotadas pelo Brasil no conturbado cenário político internacional da época: a necessidade do Brasil se defender da supremacia norte-americana, de se impor perante os demais países latinoamericanos, de se posicionar ou não diante dos conflitos da Segunda Guerra Mundial. " (SILVA, p. 1. 2013)

\section{Figura 2}

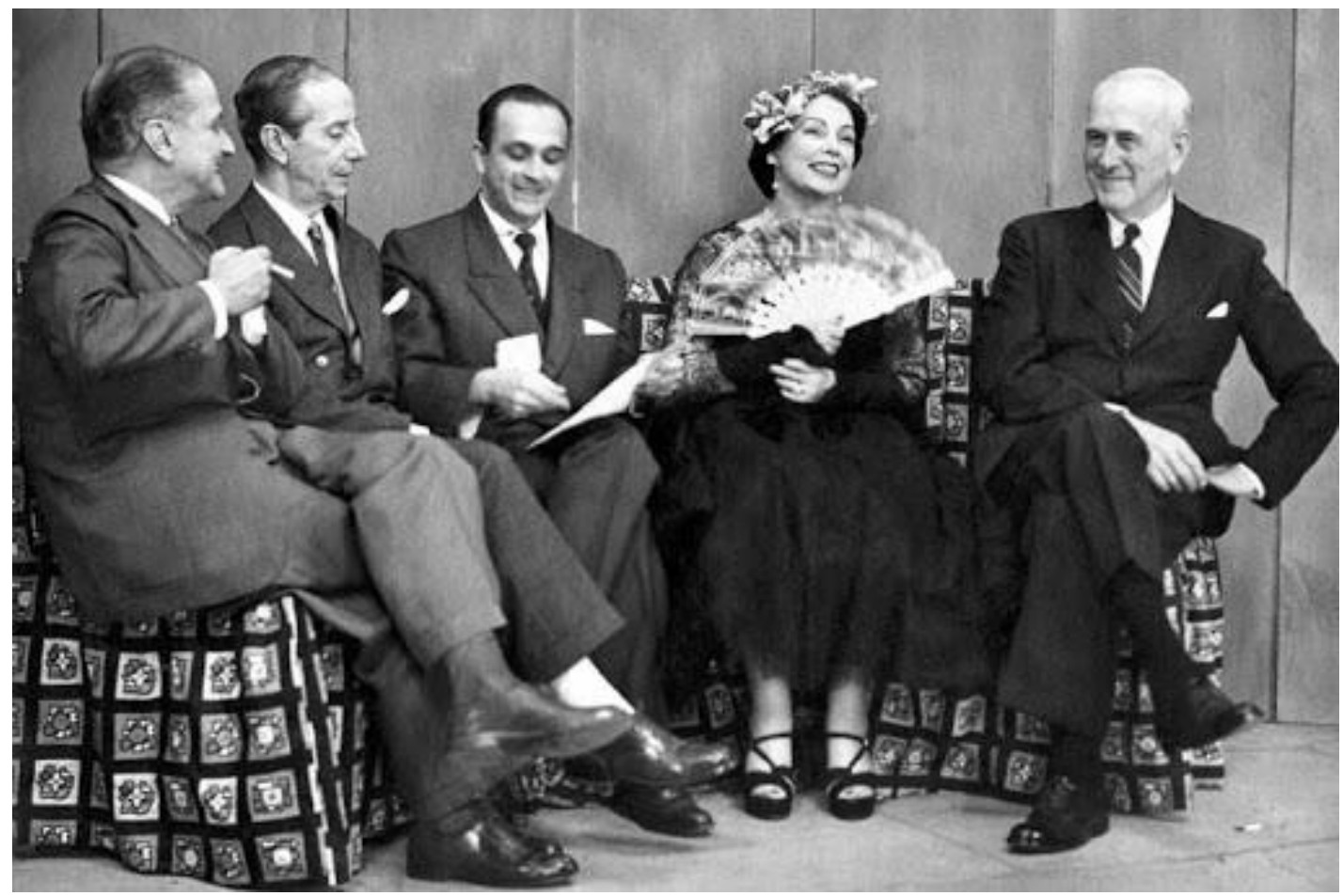

Fonte: Acervo do CPDOC

Rosalina realmente deixou sua marca dentro da política geral, mas se estabeleceu como uma das principais figuras que se posicionaram em favor às causas das mulheres em nosso país. Com certos posicionamentos políticos muito similares aos de Getúlio, sempre se pondo contra as ditas tentativas comunistas de dominarem o país, Rosalina deixou de se mostrar extremamente necessária para o avanço das questões femininas.

Além disso, Rosalina atuou intensivamente em favor da causa feminina e do divórcio, utilizando de sua influência política e de seu destacado papel 
na sociedade carioca na tentativa de angariar melhores condições para as mulheres. Anticomunista fervorosa, estava sempre atenta às ameaças internacionais de implementação do comunismo no Brasil, alertando Vargas dos riscos. Participou também ativamente do movimento integralista e enfrentou várias críticas de seus contemporâneos, que a associavam como simpatizante do nazismo. (SILVA, p. 1. 2013)

\section{Figura 3}

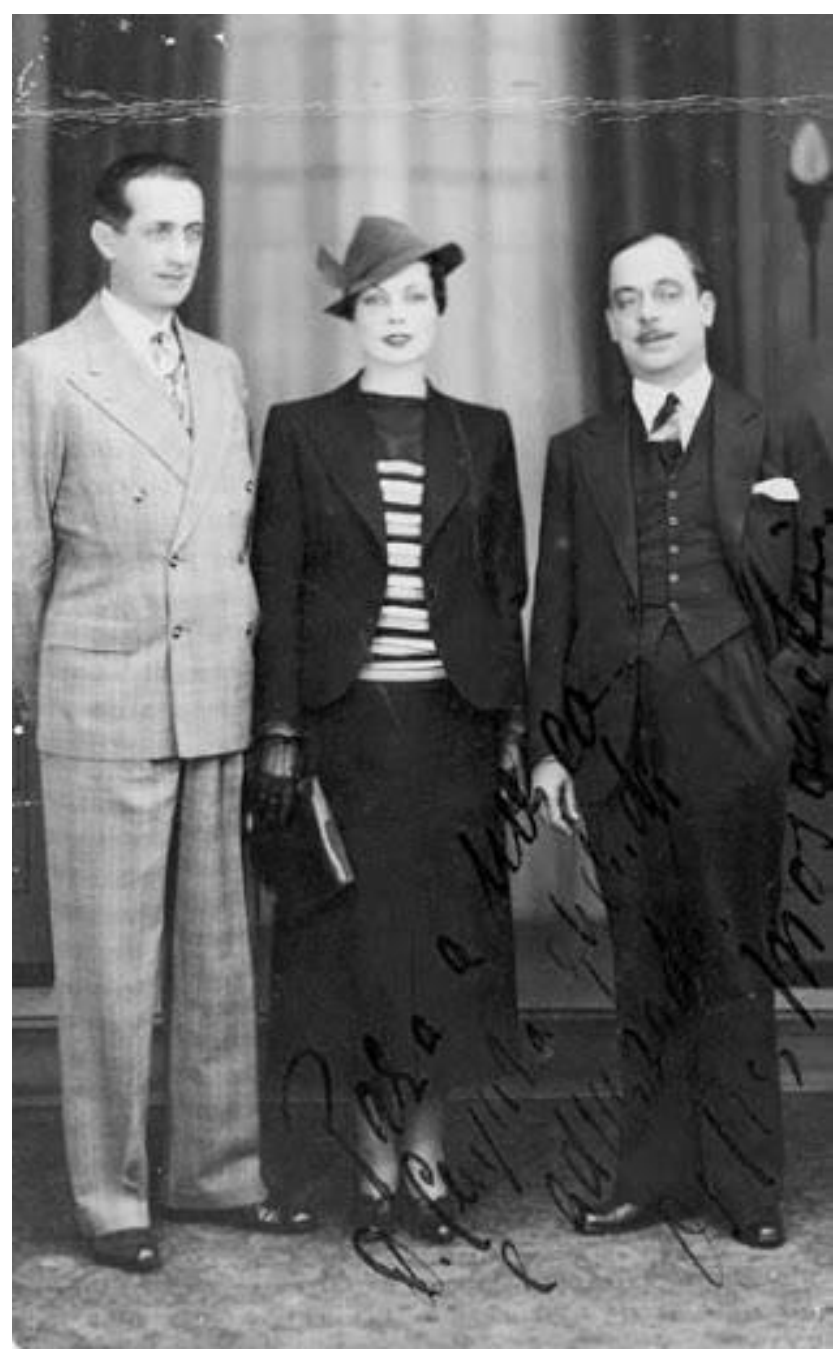

Fonte: Acervo do CPDOC

\section{OBRAS PUBLICADAS}

Rosalina teve entre suas publicações quatorze livros, como os muito conhecidos "Rito Pagão", de 1922, e "A seara de Caim", lançado em 1952. Ademais, ela chegou a produzir alguns artigos e manuscritos. 
Figura 4

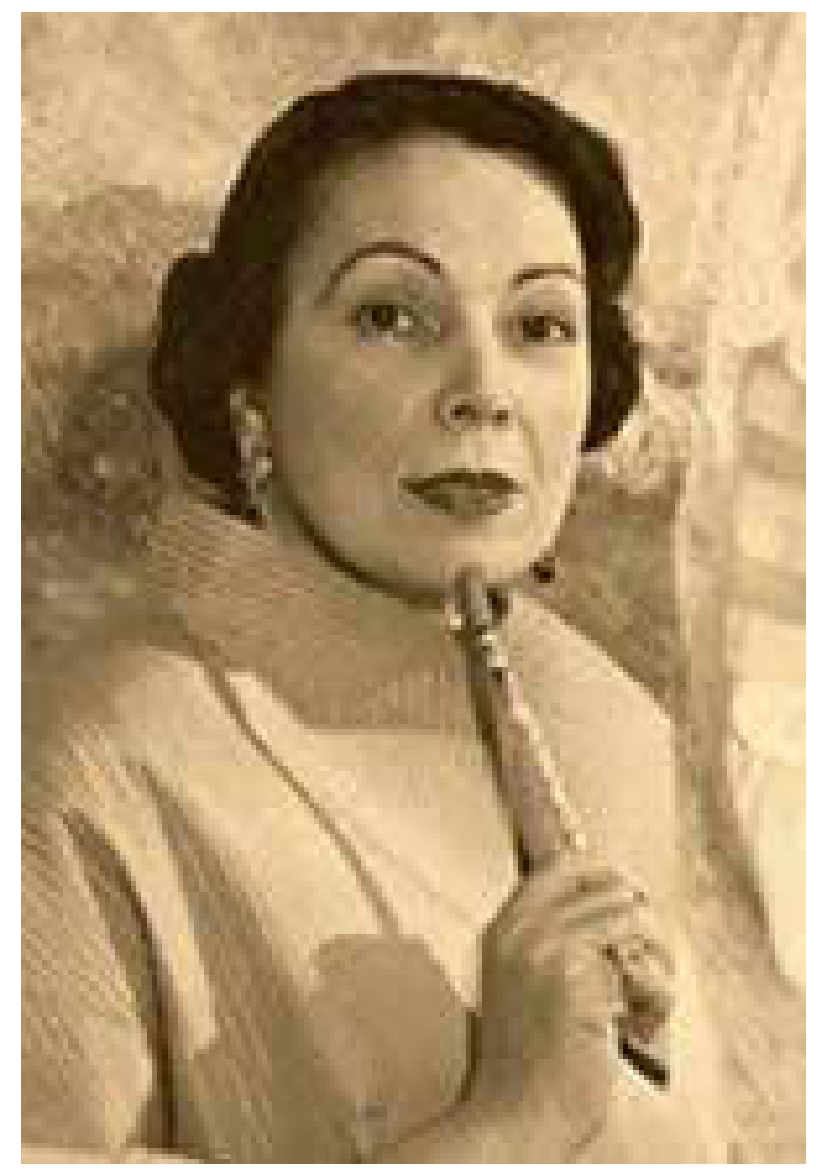

Fonte: Site Babelio

Rosalina publicou seu primeiro livro, já comentado, "Rito Pagão", através da editora Monteiro Lobato, no ano de 1921. Por conta dessa obra, ela tornou-se a campeã de um concurso literário da Academia Brasileira de Letras. Seis anos depois, ela publica o livro "Conferências"; ainda em 1927 também ocorre a publicação de um livro de ensaios, "O desencanto encantado", através da editora Companhia Nacional. (SILVA, 2013)

Em 1932 Rosalina escreveu um livro de poemas, o "Passos no Caminho", o qual chegou a ser traduzido para o Espanhol; sua publicação no Brasil se deu por meio da Editora Renascença, já a em língua espanhola, em 1946, pela Edições Diana. O livro foi publicado também pela Ediciones Idea, em Madri. (SILVA, 2013).

A obra "A seara de Caim" foi publicado no Brasil no ano de 1952, através da Editora José Olympio, e sofreu cinco reedições entre o ano de lançamento e 1956. O livro teve muita repercussão entre a população, produzindo um reconhecimento para a autora, especialmente no exterior. A seara de Caim recebeu a aclamação da crítica 
internacional, tanto que recebeu traduções para espanhol e francês. "Les moissons de Cain" chegou a ganhar o prefácio de um dos prestigiados membros da Academia Francesa, André Maurois. Enquanto isso, a edição espanhola recebeu o prefácio de Gregorio Marañón. (SILVA, 2013).

Posto isso, conforme Silva (2013), sabe-se que os livros de Rosalina tiveram não só uma enorme repercussão na Europa, mas também na América Latina. Ademais, como encontrado no Guia dos Arquivos do CPDOC (FGV), Rosalina escreveu também artigos para jornais como $O$ Globo, O Jornal do Brasil, Correio da Manhã, $A$ Nação, entre outros. A autora sempre se posicionou como anticomunista, mas como completamente à favor da emanipação e do progresso da causa feminina.

Figura 5

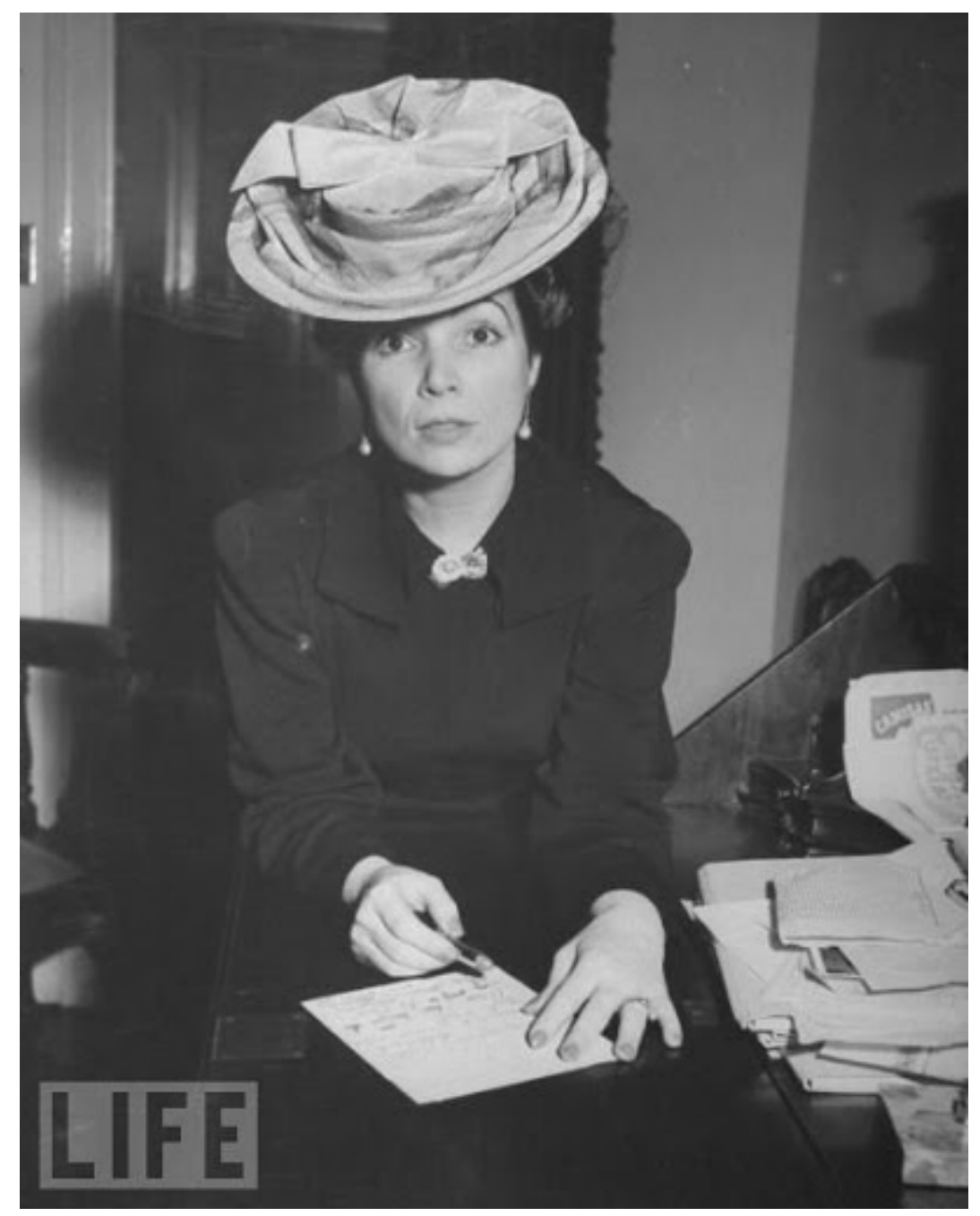

Fonte: Site Revista Tema Livre 


\section{CONSIDERAÇÕES FINAIS}

Perante o exposto, fica evidente como a vida e obra de Rosalina faz parte da história das mulheres de nosso país. As mulheres brasileiras possuem diversas faces e poucas delas obtiveram a influência que Rosalina adquiriu através de sua atuação ativa na organização política do Brasil, além de sua grande quantidade de obras publicadas como livros e artigos para jornais e revistas.

Os lugares das mulheres na história brasileira nem sempre são lembrados, principalmente quando falamos sobre a história política do país, mostrando-se assim a relevância de pesquisas que demonstram a influência feminina no mundo público que era visto como ambiente predominantemente masculino. Esperamos, então, que a importância de Rosalina seja relembrada pela historiografia.

\section{REFERÊNCIAS}

FGV. Guia dos Arquivos do CPDOC. Disponível em:

http://www.fgv.br/cpdoc/acervo/dicionarios/verbete-biografico/rosalina-coelho-lisboalarragoiti. Acesso em: 5 março 2021.

SCHMIDT, Benito Bisso. Quando o historiador espia pelo buraco da fechadura: biografia e ética. História (São Paulo) v.33, n.1, p. 124-144, jan./jun. 2014.

SILVA, L. G. M. Vida e obra de Rosalina Coelho Lisboa: desafios e limiares do método biográfico. XXVII Simpósio Nacional de História. ANPUH, Natal. 2013. Disponível em: http://www.snh2013.anpuh.org/resources/anais/27/1364593168_ARQUIVO_ VidaeobradeRosalinaCoelhoLisboa.pdf. Acesso: 1 março 2021. 


\section{O ESPECTRO DA IMAGEM: SARTRE, HUSSERL E BERGSON}

Caio César Costa Santos ${ }^{60}$ 


\section{INTRODUÇÃO}

O que é a imagem? O que pode a imagem? De onde ela surge? A imagem é propriamente o acontecimento? Ou ela é o espectro do pensamento? Há relação entre tempo, pensamento e imagem? A imagem gera-se da estruturação do pensamento? Ou a imagem é o próprio pensamento? Essas questões iniciais levam-nos a trilhar um caminho tortuoso de modo que nem a Filosofia, nem as Neurociências ou até as Ciências Cognitivas não conseguiram atribuir um significado que seja abrangente e, mais, que contemple toda a potência que está encrustada na designação do que seja uma imagem. De todas as imagens que existem no mundo e das imagens criadas da relação do Ser com o mundo como: as imagens pictóricas, visuais, eidéticas, hipnagógicas, subjetivas, espaciais, temporais e até mesmo mentais, sobre estas últimas é que iremos nos deter neste texto. A imagem mental é a de ser uma imagem-pensamento? O que pode o pensamento em relação à imagem e o que pode a imagem em relação ao pensamento? Com uma única imagem que aparece a nós, podemos conjugar pensamento e imagem? A imagem seria a identificação do self ao se revelar para o eu mais profundo? A imagem seria o invólucro do tempo? Neste sentido, a imagem vive sem o tempo ou a própria imagem é a duração do tempo? Do pensamento para a imagem, o espaço imaginário é o mesmo ou há diferenças de natureza? A imagem mental, por ser "mental", advém mesmo da mente? No decorrer da minha escrita, tentarei responder provocativamente algumas destas questões.

Para isso, neste artigo, me deterei na abordagem sobre a imagem mental em três filósofos - são eles - Sartre, Husserl e Bergson. Para Sartre, a imagem pressupõe um objeto e do objeto pressupõe-se uma experiência e da experiência pressupõe-se a temporalidade. Seguindo este fio condutor, Husserl entra, ao relacionar a imagem com a consciência interna do tempo. Para Husserl, a imagem-pensamento forma-se a partir da cauda retencional do passado, ou seja, daquilo-que-mesmo-foi e daquilo-que-acabou-de-passar-agora. As linhas fantasmas que se criam com a sucinta interpolação e conexão dos eixos temporais entre aquilo-que-foi e aquilo-que-passa-agora sugerem a construção ininterrupta de imagens que se combinam espiritualmente, formando uma sucessão de modos temporais que ora recuam, ora avançam, partindo-se de uma extrema sensibilidade do espectro do tempo o qual atinge camadas e 
mais camadas profundas dos índices invisíveis do tempo. Sobre esta interconexão de infinitas camadas de sentido do tempo, Bergson aparece fantasmaticamente ao conceber a memória como uma memória-fantasma, uma memória que está encrustada no espírito, mas que reincide na alma substancial dos corpos-objetos que são representados como imagens. A partir disto, há uma luta conglomerada de imagens que se duelam, se rivalizam, se dissociam, se distendem, ampliam-se e, no final, se atualizam. A imagem atualizada construída seria decididamente a vencedora, aquela que apareceria à nossa frente, sem contar as inúmeras outras imagens codependentes que se criam bruscamente e sem cessar o intervalo entre elas.

Estas três visões da imagem mental que serão reexaminadas aqui, a de Sartre, a de Husserl e a de Bergson, tem o intuito de nos movermos ora em um, ora em outro, formando uma discussão rica de reflexões. De início, a imagem mental não seria aquela construída pelo cérebro, pela mente ou pela consciência. Nos referimos aqui mais à consciência interna do tempo que, com a substancialidade do Ser, envolve toda a relação sensível do objeto visto ou percepcionado com a duração retencional do tempo. A minha defesa é a de que a imagem mental, por ser "mental", não está na mente, ao contrário, a mente ou o cérebro é somente uma outra imagem codeterminante ou coexpressiva da imagem mais inferior que se cria com os espaços temporais. Neste sentido, a imagem mental da "consciência" (do tempo) seria o invólucro das imagens sucessivas e complementares mais inferiores. O estado atual da imagem é ou foi o germe originário da cauda retencional do passado que a inscreveu e a fez potencializar. Na potência que a concebeu e a fez germinar, a imagem é uma das poucas imagens que sobrevive à ação destruidora do tempo. Refiro-me à imagem da subjetividade, à imagem interior à ela mesma, não interior a um eu, a um corpo ou a uma substância, mas interior à consciência interna do tempo, para empregar um termo husserliano. A imagem necessita do fluxo da temporalidade, embora necessite também de uma substância criadora subjetiva para não apenas existir no mundo, mas para coexistir com as diversas formas-potência do mundo. A imagem tem um caractere particular: ela acontece não somente no mundo sensível, mas no além-mundo, não apenas no mundo das significações, mas no mundo extrassensível, extracorpóreo e imaginário. A imagem pode atingir até o Cosmo, se pensarmos em uma consciência, reflexão ou experiência imaginante transcendental. 
Neste sentido, a imagem, neste caso, mental, ultrapassa fronteiras metafísicas criadas ou não pelo homem. Basta nós pensarmos nas construções imagéticas dos primeiros homens que habitaram a terrra. Nestas imagens, havia uma pressuposição do universo, dos deuses, das formas múltiplas da Natureza e até de outros mundos, por que não pensar dos alienígenas? A imagem mental seria, então, a potência ela mesma, a potência por excelência. O que torna a imagem potente é nada mais que a vivacidade da potência. Não potência de poder, poderio ou hierarquia, mas potência de potencialidade, assim como um único invisível átomo é potente o suficiente para mudar o fluxo de uma substância qualquer. A imagem arranca a potencialidade da potência tornando-se também força potente. Como força potente, acopla-se à temporalidade, se insinua, torna-se novamente força potente, mas mil vezes mais forte que à sua formação inicial. A força chega a se tornar tão potente que a imagem, por intermédio do tempo, organiza qual eixo temporal vem primeiro ou se todos (os eixos) devam vim juntos. A imagem chega a criar por ela mesma, a ás vezes se afastar do espectro do tempo, a adotar um espaço infinito invisível imaginado, mas não deixa de ser ela mesma: viva, potente e iluminada. Se bem que nem todas as imagens podem ser iluminadas, há, portanto, aquelas que preferem continuar o seu curso no nevoeiro do espírito, em um "lago desconhecido" ou decidem viver numa atmosfera escura e sombria. O leitor conseguirá detectar o quanto é tão potente uma imagem mental nas próximas páginas.

\section{A IMAGEM POR SARTRE}

Sartre (2019, p. 10) no livro "A imaginação" diz o seguinte na introdução deste livro: "a imagem é uma coisa menor, que tem sua existência própria, que se dá à consciência como qualquer outra coisa e que mantém relações externas com a coisa da qual é a imagem". Primeiramente, será mesmo que a imagem mental é uma "coisa menor" em comparação com a coisa real? Há ainda profundas discussões em torno de se a imagem representa a coisa ou o objeto tal como ele é. Sabemos que, ao imaginar uma cena de nosso passado, conseguimos recuperar a porção mental da imagem com ricos detalhes, com notáveis apreensões e com espaços geométricos muito semelhantes ao do acontecimento vivido. Eu diria que a imagem mental, através dos índices do tempo, transmuta estes índices, transformando-os em porções prévias. 
Na sequência de transmutação destes índices, há formações, deformações, presenças, faltas, conexões, atualizações, dissociações, entrecruzamentos, associações, desvelamentos, apreensões, etc. Ou seja, ao recuperar uma imagem de uma porção prévia contida, há a sobreposição de elementos que, na imagem, se tornam incorpóreos, destituintes mais do que constituintes. Há, no começo, uma desorganização das imagens até se chegar a uma organicidade. A imagem mental seria como um cristal que, após se quebrar em centenas de pedaços, é preciso organizá-los como um quebra-cabeça, mesmo que aparentemente isto não seja possível. Logo, numa visão fixa e real, não é possível reunir ou juntar os cacos do cristal que se quebrou e acabar formando um novo cristal. O cristal se quebrou, se dissociou e sua reintegração é impossível. No entanto, a imagem mental é capaz de criar-se a partir destas desintegrações do cristal do tempo, para relembrar um termo de Deleuze (2018).

Quando Sartre (2019) nos diz que "a imagem é uma coisa menor", ele está dizendo que a imagem está em um nível inferior em relação à coisa percepcionada. Mas, será mesmo? Concordo que a imagem mental se cria ao percepcionar um dado objeto, no entanto, as linhas ou os espaços fantasmas que contornam a superfície assimétrica da imagem dão uma aparência apesar de não semelhante, mas muito próxima da coisa percebida. É como se a consciência perceptiva fizesse o trabaIho de simular o contorno do objeto com suas qualidades intensivas e extensivas, mas muito embora não atingindo a totalidade de seu contorno. A imagem, no ato de representar, o próprio ato de representação, contêm, neste entrecurso, falhas, desvios, dissociações e algumas discrepâncias. Sartre (2019) quer nos assinalar que a imagem mental que se cria não é o objeto tão como ele é. Na hierarquia do contato entre objeto e imagem, esta última está em um nível menor. Não que a imagem "é menor" por conta de seu aparecimento efêmero. Não é nada disso. A imagem mental em relação ao objeto não é superficial, fraca, impotente, efêmera, muito embora o seu conteúdo psíquico destoe da aparência geométrica, anímica ou tonalizante do objeto. Sendo assim, a imagem não é menor em sua potência, mas menor em sua configuração própria. Ou seja, ela não representa ipso facto o objeto em sua forma bruta. É que ao observar um dado objeto como uma mesa, psiquicamente eu não consigo imaginar a mesma mesa, embora a configuração do seu conteúdo psíquico me sinalize de que é aquela mesma mesa que eu a vi há pouco. Neste caso, a

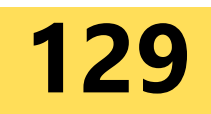


imagem me seria menor não quantitativamente, mas qualitativamente. É impossível para a potência da visão criadora da imagem em mim, eu formar um protótipo do objeto como ele me aparece com todos os seus tons, cores, geometria, intensidade, estrutura, movimento, etc. Não cabe à imagem criada em mim produzir todos estes elementos como iguais, como uma cópia fiel do objeto observado. Por ser a imagem menor, a sua aparência em relação ao objeto pode ser também menor no sentido de que a imagem tem menos atributos no ato de sobreviver à aparência do objeto. Porém, menos atributos não quer dizer menos apreensões.

Ao contrário, como disse anteriormente, a imagem, diferentemente do objeto em contato, possui múltiplas facetas, múltiplas raízes, inúmeras ramificações para relembrar outro termo de Deleuze (2018), o rizoma. A imagem mental é o próprio rizoma: uma espécie de afloramento germinativo ininterrupto de apreensões. Se o objeto "mesa" não é apresentado a mim ou não aparece a mim com todas as suas qualidades (intensivas e extensivas) não seria um problema do processo de configuração da imagem, afinal, a imagem urge por se transformar incansavelmente até atingir uma proximidade com o objeto observado ou percepcionado. A imagem urge por sobreviver a fim de encontrar um caminho que seja multiplamente recuperável, os índices da porção prévia da imagem vão se constituindo até se produzir uma emoção na interioridade do sujeito a ponto dele relembrar continuamente do objeto, de reinseri-lo múltiplas vezes nos espaços temporais até se chegar a cristalizar uma potência afetiva que, neste caso, o objeto chega a se tornar inesquecível, sempre vivo e recorrente. A imagem mental tem o intuito não apenas de detectar, mas de se aproximar e se reaproximar cada vez mais da aparência do objeto. Logo, a imagem não é menor, mas é um intervalo, uma sucessão de instantes que duram até se chegar mais próximo do objeto, bem mais próximo do que qualquer outra manifestação anímica, até porque a imagem está ali, lado a lado, com o objeto, ela é precisamente a sua segunda aparência, o seu segundo modo e, ainda assim, um modo intermediário, coalescente.

Sartre (2019) também nos comunica de que "a imagem tem existência própria". Realmente. A imagem produz e se constitui por ela própria. Ela mesma é sua unidade, o seu compartimento, a sua duração. Como disse anteriormente, a imagem, sendo ela "mental", não está na mente ou não é nenhuma organicidade contida em 
um receptáculo. Como veremos no tópico 4, o cérebro nada mais é do que uma outra imagem, é imagem da imagem da representação. Contudo, sentimos, como humanos, que a imagem, mesmo paradoxalmente, existe numa consciência perceptiva, mas isto não quer dizer que a imagem se produz na cabeça de alguém. A imagem mental não existe necessariamente na interioridade do Ser, ao contrário, ao meu ver, esta imagem está dispersa nos espaços temporais, nos intervalos que duram, na simultaneidade do acontecimento. A imagem não dura na consciência, por durar ela dura como afecção temporal à consciência. O que isto quer dizer? Metaforicamente, a imagem ou a constelação de imagens seria uma névoa, ás vezes clara, ás vezes sombria, que se insinua à consciência perceptiva. Por ser uma tal nebulosidade, ela se retroalimenta e incessantemente se reconstitui por intermédio de indíces temporais, um tipo de organicidade invisível, ausente externamente, mas que se revela pouco a pouco à minha própria consciência perceptiva. É impossível o Outro saber o que neste exato momento eu estou imaginando (formando imagens), mas isto não quer dizer tão somente que a imagem ou a imaginarização passa em mim. O mundo incorpóreo da imagem por ser incorpóreo dificulta a apreensão ou quase que impossibilita a revelação imagética para um Outro. No entanto, a imagem acontece em mim e fora de mim. Ou seja, a imagem chega a se distribuir com as coisas, chega a se alojar nas coisas, em um momento, chega a se confundir com as coisas. Muito embora, por ser uma potência, a imagem constantemente está em estado de diferenciação. Por se confundir com as coisas, em um momento de nossa vida, não sabemos com exatidão se o que me ocorreu foi real ou se foi fruto da minha imaginação. A imagem e o objeto formam uma linha tênue, sensivelmente construída. Por isso que, ás vezes, a imagem se constitui como uma apreensão do real, outras vezes como uma apreensão da apreensão do real.

Para finalizar este tópico, cito novamente Sartre (2019, p. 19), ele nos diz: "a imagem é o domínio da aparência, mas de uma aparência a qual nossa condição de homem dá uma espécie de substancialidade". Chega a ser impossível para um homem conhecer com exatidão se uma pedra ou uma mesa pensa por ela própria, ou melhor, produz em si imagens, Do animal, sabemos que esta criação é possível. No entanto, coube ao homem tornar a imagem uma substância, torná-la em si uma coisa apreensível. $\mathrm{O}$ fato de o homem substancializar a imagem a atribui uma espécie de

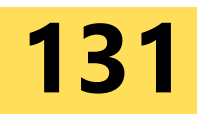


existência para ele. Mas, a imagem por si e nela mesma já é presença, se configura como uma coisa existente no mundo, mesmo que este mundo não seja sensível. Mas, é de se pensar se aonde existe uma porção, mesmo que mínima de sensibilidade, coexiste uma imagem. Se uma pedra ou uma mesa contém um teor, mesmo que ínfimo, de sensibilidade, é de se pensar se ambas coisas pensam, imaginam. Mas, é de se pensar também se o conteúdo sensível que a coisa (uma pedra ou uma mesa) possui não é um intermédio ou uma cauda retencional da existência de uma afecção com o homem. Poderíamos dizer, arriscando-se, que o homem e a pedra pensam juntos ou que as duas imagens de ambos fenômenos se criam no contato afeccional. Até porque a pedra nos afeta e o homem afeta a pedra. Porém, poderíamos pensar se pelo fato de a pedra nos afetar nos seria por conta da existência de uma consciência perceptiva. No mais, poderíamos encerrar este tópico dizendo que "a imagem não é senão a coisa enquanto esta mantém com outras coisas um certo tipo de relações" (SARTRE, 2019, p.21).

\section{A IMAGEM POR HUSSERL}

Husserl (1994) em seu livro "Lições para uma fenomenologia da consciência interna do tempo" nos demonstra, mesmo que indiretamente, como, no intervalo dos espaços temporais, em cada um destes espaços, coexiste uma imagem, imagem esta da consciência interna do tempo. Vejamos o que ele diz ao olharmos para um giz:

Consideremos um pedaço de giz; fechamos e abrimos os olhos. Temos então duas percepções. Nós dizemos neste caso: vemos duas vezes o mesmo giz. Temos neste caso dois conteúdos temporais separados, observamos também uma distinção temporal fenomenológica, uma separação, mas no objeto não há qualquer separação, ele é o mesmo: no objeto, duração; no fenômeno, mudança (HUSSERL, 1994, p. 41).

De certo modo, a objetividade do objeto "um giz" ao fecharmos e abrimos os olhos para ele não muda. O tal giz é o mesmo para ambas percepções. Como diz Husserl (1994): "vemos duas vezes o mesmo giz". Mas, o que pensar de diferencial nisto? Não discordo que realmente vemos duas vezes o mesmo giz, mas, como Husserl nos explica, a duração do objeto não é a mesma, ou seja, o intervalo entre fechar e abrir os olhos não é o mesmo. No brusco ato de ver e fechar os olhos para o giz, 
eu criei em mim uma espécie de imagem originária da cauda retencional do evento anterior. Ou seja, o objeto "giz" reaparece para minha consciência perceptiva em uma segunda vez (ao fechar os olhos) e numa terceira vez ao abri-lo. É o mesmo que dizer que "o assim mantido na consciência nos apareça como algo mais ou menos passado, como, por assim dizer, temporalmente lançado para trás". (HUSSERL, 1994, p. 45). O giz assim mantido na consciência perceptiva sobrevive em imagem para mim; é como se ao eu visualizar o giz pela primeira vez o contivesse retido em mim e ao abrir os olhos me deparasse com a mesma imagem daquela que sobreviveu há um tempo atrás na minha consciência perceptiva. Ou seja, o giz não desaparece do meu campo visual sem deixar rastros, sem se deixar formar índices temporais que se cristalizam em minha consciência. Aquilo que é precedente retorna, há um eterno retorno daquilo que eu vi ou experienciei, mesmo que eu não queira que aquilo acontecesse. A imagem se constrói, se torna um vivente na minha consciência. Algo ainda que eu posso percebê-lo em sua segunda ordem, algo que vive em mim, que fará parte de meu passado, que eu criarei outros espaços temporais com aquela mesma experiência com o giz, provocando uma constelação abrupta de imagens, assustadorosamente remissíveis. Após eu olhar para o mesmo giz, ele se contém em minha memória retrospectiva e não desaparecerá enquanto eu não pensar em uma outra coisa, em um outro objeto. E, mesmo assim, ele, o giz, estará lá, vivo e resplandecente.

Esta imagem do aparecimento fantasmático do giz em mim se assemelha ao soar de uma melodia. Husserl (1994, p. 45) diz: "Quando, por exemplo, soa uma melodia, o som individual não desaparece completamente com o cessar do estímulo ou então com o movimento dos nervos por ele excitados. Quando soa o novo som, o precedente não desaparece sem deixar rastro, senão nós seríamos incapazes de notar as relações entre os sons consecutivos". No caso do giz, quando vemos-o acontece que aquilo que é percepcionado permanece em mim por um lapso de tempo, mas, claro, não sem se modificar. Na verdade, o giz que eu vi de imediato e o giz que eu lembrei como imagem não são "vistos" de modos sucessivos. Há, entre estes dois fenômenos, o visto e o imaginado, uma ruptura, uma espécie de deslocamento da síntese perceptiva temporal. Pode parecer para mim que o giz é o mesmo entre os dois intervalos, mas fenomenologicamente não é. O giz-que-agora-é foi o giz-que-agora-passou. E, mesmo-passando-agora ele me é um-passado-que-é. Ou seja, mes-

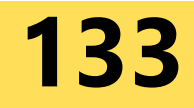


mo que aparente para mim o mesmo giz, ele sofreu uma modificação, me ocorreu uma alteração da síntese perceptiva temporal fenomenologicamente. Nesta cadeia recursiva de elementos mnêmicos, há uma lei universal para todo tipo de representação deste tipo. Segundo Husserl (1994, p. 46): "é, por conseguinte, uma lei universal que, a cada representação dada, se ligue, por natureza, uma cadeia contínua de representações, da qual cada uma reproduz o conteúdo precedente, mas de tal maneira que ela fixe sempre à nova o momento do passado". A cada nova apreensão, há uma contínua cadeia de reprodução de representações ou, se preferir, de contínuas imagens coalescentes. Para cada apreensão da síntese perceptiva temporal do objeto, há uma cascata de representações. Mas por ser uma espécie de "cascata" não quer dizer que a criação de imagens seja feita indistintamente, sem relações entre si. Ou seja, para cada ato, uma imagem, para cada imagem, uma relação. Relação esta que só muda na sucinta alteração da síntese temporal construída no interior desta mesma relação. Eu evoco o giz e, dentro desta evocação, se cria em mim e fora de mim uma relação temporal, sempre relacionada com a imagem precedente.

Ora é a força bruta do real que invade a lembrança e ora é a própria lembrança como representação em forma de imagem que invade sucessivas vezes o próprio contorno das múltiplas imagens que se oferecem para justapô-las em um espaço que parece pequeno à invasão sem limites destas imagens. Mesmo que retirado de um pequeno fragmento da memória, a imagem assim sobrevive. Afinal, as representações, as imagens, os lapsos sobrevivem no interior de fragmentos episódicos ou de pequenos instantes ou durações. Neste sentido, nenhum fragmento da memória pode ser negligenciado. Todos são comuns, todos podem pertencer à síntese perceptiva do tempo. No caso do giz, o seu conteúdo psíquico pode regredir bem para trás e cada vez mais para trás, mas, ainda assim, é possível que se mantenha conscientemente o ponto originário que se cristalizou no primeiro contato com o giz. Husserl (1994, p. 49) explica este entrecurso com outras palavras, ele escreve: "tudo que é virá a ser passado, em consequência do fato de que é, e é, em consequência do fato de que é, um passado vindouro". Pelo fato de o giz ser percebido duas vezes (ao fechar e abrir os olhos), ou seja, em duas percepções, fica claro que em cada ato perceptivo, se cria correspondentemente uma imagem e, dentro desta imagem, há uma duração que acaba como que tornando o momento singular. $\mathrm{E}$, dentro de cada

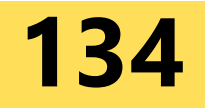


uma destas singularidades, há um movimento da potência de acontecer único que destoa de todos os demais. É o mesmo que dizer que um objeto como o giz reflete algo, este algo contém a potência de uma singularidade a qual tem o poder de movimentar o curso temporal da síntese perceptiva. Com isto, "é manifestamente visada uma lei psicológica acerca da nova formação das vivências psíquicas a partir da base de vivências psíquicas dadas" (HUSSERL, 1994, p. 49).

Para cada vivência do estado reflexivo do giz em mim, realinham-se novas formações de vivências em mim, levando a uma formação de estados do giz que não cessam de acontecer até que a minha consciência perceptiva surpreenda-se com outro estado anímico de ser de outra coisa, em outras palavras, até que eu desfocalize o giz de meu centro perceptivo e viva outra estado de vivência, fazendo com que eu esqueça do giz. Se bem que não se esquecerá deste estado anterior até que novas formações de vivências sejam mais determinantes e acabem como que me surpreendendo mesmo por um intervalo de tempo. Do giz, não se esquece, embora por pequenos intervalos de tempo ou pode se chegar ao ponto de que eu esqueça completamente, após redigir este texto, muito embora ele possa retornar mesmo como um lampejo em um dado momento de minha vida. Neste caso, por conta de seu reaparecimento, a imagem do giz continuará ainda mais forte em mim, aumentando exponencialmente até se tornar uma imagem presente no meu cotidiano. Ou seja, quanto mais eu lembrar, mais forte ele estará contido em mim. E, quanto mais eu lembrar, mais difícil será para mim esquecê-lo. Quanto mais vivências, mais apreensões. Quanto mais apreensões, mais reflexões e, por fim, mais atualizações do giz.

\section{A IMAGEM POR BERGSON}

Chegamos ao tópico final. O tópico sobre a imagem em Bergson. Bergson nos demonstra que para todo objeto contido no mundo há, ao seu lado, uma imagem. É como se fosse a sombra que reflete a aparência sombria de nosso corpo. Para cada objeto, há correlativamente a sua sombra, o seu reflexo. Só que Bergson vai mais longe e observa que até o nosso ato de pensar é um reflexo do reflexo de um objeto. Aparentemente, a nossa consciência é puramente reflexiva, ou seja, é um reflexo em sua forma absoluta. Para Bergson, se o nosso cérebro é um órgão de atenção à

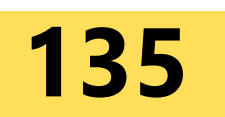


vida, então, obviamente, ele só se torna atento em relação às coisas do mundo partindo-se de um modo reflexivo. Ou seja, o cérebro é, para ele, pura reflexão. E, por ser reflexão, ele se substancializa em imagem. Para Bergson, o cérebro não passa de uma pura imagem. Neste sentido, se representamos o mundo por intermédio de representações em forma de imagens, o cérebro seria então uma imagem da imagem da representação. Em outros termos, uma grande imagem que produz novas imagens. Se caso imaginamos o cérebro como uma imagem dentro de outra imagem que se apresenta a nós como um cérebro, então, pensamos como uma imagem (o cérebro por ele mesmo) da imagem (sua representação) da imagem (reflexão) da representação. Para Bergson, o cérebro seria uma imagem porque os nossos estados psicológicos parece ultrapassarem o estado cerebral. Ou seja, todos os mecanismos cerebrais em conjunto não explicariam todos os fenômenos da nossa vida psíquica. O cérebro seria mais um órgão de atenção e movimento para a vida, não passando disto. Cito Bergson (2010, p. 13), "para que essa imagem que chamo de estímulo cerebral engendrasse as imagens exteriores, seria preciso que ela as contivesse de uma maneira ou outra, e que a representação do universo material inteiro estivesse implicada na deste movimento molecular".

Como dito anteriormente, é incapaz para o cérebro condensar todas as formas de vida, todos os fenômenos intensivos e extensivos, toda a invisibilidade do ato de perceber e recordar e ainda toda a potência do tempo e da envergadura do espaço. Impossibilitado de absorver toda esta imensidão, o cérebro, para nós, nada mais seria do que uma imagem. E Bergson (2010, p. 13) continua: "fazer do cérebro a condição da imagem total é verdadeiramente contradizer a si mesmo, já que o cérebro, por hipótese, é uma parte desta imagem". Mas, aí surge uma lacuna para nós: e qual seria esta imagem total? Uma imagem que representaria todas as imagens das forças anímicas do mundo? Uma imagem que sobreviveria à ação destruidora do tempo? Uma imagem ainda que se contivesse na imensidão inatingível do espaço cósmico? Segundo Bergson, o meu corpo é uma imagem, a reflexão de minha subjetividade é outra imagem, o meu passado é imagem, presente e futuro também, então, que grande imagem total esta que poderia condensar e determinar todas estas imagens? Que substância ou que potência poderia ainda condensar os fenômenos do mundo incorpóreo, metafísico ou espiritual? Não sei se seria uma imagem, mas uma força, 
que está além de uma imagem, que devora tudo e todos: esta força é o tempo. De qualquer modo, poderíamos até nos questionar se o tempo que passa em nós e nas coisas do mundo não seria mesmo uma grande imagem, um grande reflexo. Pois, afinal, sabemos que o cérebro é apenas um elemento enquanto vivo que tem atenção à vida, não passa de uma substância pensante. Mas, e o que pensa em nós? Se não é o cérebro o nosso pensamento, então, quem pensa em nós e por nós? Na verdade, mais forte e potente que o cérebro ou qualquer substância psíquica, é a potência do acontecimento. Muito maior do que a potência do pensamento.

O acontecimento é o invólucro do tempo. É ele que faz passar os instantes em nós. Claro que o acontecimento necessita de uma presença ativa para o seu desencadeamento, mas o acontecimento é a própria potência viva em nós ou fora de nós. O acontecimento não seria, ao meu ver, uma imagem, mas o acontecido já se insinuaria para nós como uma imagem. O acontecido já seria para nós uma forma dinâmica do tempo. Seja o acontecido-que-agora-passou ou o acontecido-que-agora-é. Para todo acontecido existe uma cauda retencional do passado que contamina novos acontecidos viventes. O acontecido se apresenta a nós como uma vivência, é o mesmo que dizer que é possível também agir por atos lembrados, como eu escrevi sobre o tema em Santos (2020). O acontecido seria então uma imagem da imagem da representação, o que aconteceu sobrevive como imagem e esta imagem está em relação com a representação que eu faço dela. É como nos diz Bergson (2010, p. 15), "à medida que meu horizonte se alarga, as imagens que me cercam parecem desenhar-se sobre um fundo mais uniforme e tornar-se indiferentes para mim". Ou seja, quanto mais distante eu estiver do acontecido, quanto mais o meu horizonte em relação a ele se distender, aquela imagem do acontecido se tornará menos relevante para mim e, portanto, indiferente. Chegando ao ponto de eu me questionar: de onde veio esta lembrança? De onde surgiu esta imagem? Apesar de indiferente para mim pelo fato de meu horizonte ter se expandido, a imagem, ainda assim, continua viva em minha memória. Chegando, por ventura, a se alojar no campo da lembrança pura. A "lembrança pura" para Bergson é um estado impotente da lembrança. Na designação freudiana, seria o nosso inconsciente. Lá estão nossos recalques, nosso lapsos, nossas reminiscências mais obscuras, etc, que só através de uma nova vivência com o acontecido, é possível relembrá-los ou mesmo através de um objeto que recorde-

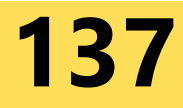


-os ou de uma ruptura da lembrança que bruscamente me leva às profundezas deste "lago desconhecido".

Segundo Bergson (2010, p. 35), "o que é dado é a totalidade das imagens do mundo material juntamente com a totalidade de seus elementos interiores". Não se é dado apenas uma parte ou porção da imagem, quando a imagem se constitui, ela se constitui inteiramente, com toda a sua potência. É verdade que a imagem se retroalimenta de pequenos fragmentos mnêmicos, de pequenas porções de memória, de momentos ou instantes estilhaçados assim como um cristal que se quebra em mil faces. Mas, a memória tem toda a potência de reunir os cacos da história para relembrar um termo de Walter Benjamim recuperado por Gagnebin (2018). A memória se retroalimenta dos pequenos indícios que são, na maioria das vezes, negligenciados pelo homem. Até aquilo que é deixado à parte, fora do eixo, a memória aceita carregar este fardo. Dos sonhos mais extraordinários é verdade que se formaram de pequenas desatenções de nossa consciência, de pequenos detalhes que se passaram despercebidos por nós, mas que, mesmo assim, encontraram alguma brecha para, mais tarde, tornarem-se em algo bem mais potente. Seja de uma imagem na televisão que eu ligeiramente vi, passei apenas o olhar, a um som desconhecido que me invadiu inesperadamente. Tudo isto é grande para a memória, pode se tornar grande, forte e potente. Do acontecido, resta a experiência e da experiência resta a imagem e da imagem? Restam outras tantas imagens; maiores, menores, menos ou mais potentes, mas que são imagens, têm a potência de ser imagens.

\section{CONCLUSÃO}

Espero que o objetivo de escrever este texto tenha se cumprido. Não procurei em momento algum escrever sobre uma teoria particular da imagem. Ao contrário, procurei dar voz a três pensadores que pensam, cada um à sua maneira, a imagem. Em cada um destes pensadores, procurei detectar um ponto culminante de cada teoria, não no intuito de combater pontos de vista, mas apenas de realçar o pensamento complementar de um para outro. Na esteira de Sartre, procurei, em linhas gerais, tecer uma linha argumentativa que focalizasse, sobretudo, a imanência da imagem, sua configuração no tecido mnêmico, o problema de conceber a imagem como uma

\section{8}


unidade menor em relação à coisa, o aspecto de sua existência própria, suas relações com a externalidade, etc.

$\mathrm{Na}$ esteira de Husserl, procurei explicar fenomenologicamente a aparição ou as aparições da imagem na estruturação da consciência interna do tempo. Procurei relacionar a sua "teoria da temporalidade" com o aspecto da aparição da imagem. Procurei dar sentido à questão: como a imagem sobrevive na consciência (interna do tempo)? Procurei ainda frisar que esta "consciência" não se refere necessariamente ao famoso enunciado husserliano "consciência de alguma coisa", mas refere-se à consciência que há intrínseca ao tempo. Procurei deixar claro, em breves linhas, como se constitui a síntese perceptiva do tempo, de que modo a cauda retencional do passado faz reaparecer novas linhas fantasmas que contribuem para novas formações de vivências psíquicas. Dei o exemplo do giz proposto por Husserl e tentei, na medida do possível, esclarecer alguns pontos no tocante à sobrevivência de sua imagem no tecido do tempo.

Vimos que o fechar e o abrir os olhos tendo diante de si um giz não são fenômenos idênticos no tocante à duração do tempo visto que o curso temporal do objeto percebido não é o mesmo do curso temporal do objeto imaginado. Procurei explicar este estado do giz fenomenologicamente. Na esteira de Bergson, salientei alguns pontos os quais argumentavam que para todo objeto há correlativamente uma sombra ou o seu reflexo. Procurei ainda postular, concordando com Bergson, de que a nossa própria massa cinzenta (o cérebro) por ser uma substância psíquica não quer dizer necessariamente que ela condensa todos os movimentos anímicos da natureza, a saber, as formas da vida, os fenômenos corpóreos e extracorpóreos, a invisibilidade da apreensão temporal, todas as dores do mundo, todas as imagens deste mundo, etc. O cérebro em relação ao mundo seria nada mais que uma imagem, uma imagem da imagem da representação. E ainda questionei se o nosso cérebro não é a imagem total do mundo, então, qual ou quem seria a imagem total?

No mais, espero que estas discussões possam aguçar mais e mais nossa curiosidade de compreender este mundo em que vivemos: paradoxal, esquisito, sobrenatural, mas fantástico. 


\section{REFERÊNCIAS}

BERGSON, H. Matéria e memória: ensaio da relação do corpo com o espírito. Tradução de Paulo Neves. São Paulo: Martins Fontes, 2010.

DELEUZE, G. A imagem-tempo. Tradução de Eloisa Araújo Ribeiro. São Paulo: Editora 34, 2018.

GAGNEBIN, J. Walter Benjamim: os cacos da história. Tradução de Sônia Salzstein. São Paulo: n1 edições, 2018.

HUSSERL, E. Lições para uma fenomenologia da consciência interna do tempo. Tradução de Pedro M. S. Alves. Lisboa: Imprensa Nacional-Casa da Moeda, 1994.

SANTOS, C. O fantasma de Bühler: a sombra da dêixis que se prolonga no passado. In: LIMA, G.; MATOS, S.; SANTOS, C. Pesquisa em linguística: abordagens contemporâneas. v. 4, 2020, p. 93-117.

SARTRE, J-P. A imaginação. Tradução de Paulo Neves. São Paulo: L\&PM, 2019. 


\title{
A TEMÁTICA DA HISTÓRIA E CULTURA AFRO-BRASILEIRA E INDIGENA NOS LIVROS DIDÁTICOS DE HISTÓRIA NO ENSINO MÉDIO
}

\author{
Rafael Kunst Haygert ${ }^{61}$ \\ Priscila Gualberto de Lima ${ }^{62}$
}

61 Pós-graduando em Políticas Públicas e Direitos Sociais pelo Centro Universitário Internacional (UNINTER) e licenciado em História pela mesma universidade. Endereço de e-mail: rafaelhaygert@ gmail.com.

62 Possui graduação em Administração pela Universidade Estadual do Rio Grande do Sul (2007), graduação em Licenciatura em Ciências Sociais pela Universidade Luterana do Brasil (2014), especialização em Administração Pública e Gerência de Cidades pela Fatec (2009), mestrado $m$ Ciências Sociais pela Universidade Federal de Pelotas (2010) e doutorado em Sociologia pela Universidade Federal do Rio Grande do Sul (2014). Atualmente, é docente do Instituto Federal Farroupilha (IFFar, Campus São Borja). Endereço de e-mail: priscila.lima@iffarroupilha.edu.br. 


\section{INTRODUÇÃO}

Resgatando a história dos negros e índios na nação brasileira, nota-se que o escravismo colonial fez parte da formação do Estado brasileiro e tudo o que se produzia aqui era para o sustento da metrópole portuguesa. Assim, os indígenas, no início, e os negros, posteriormente, foram escravizados e excluídos do acesso à riqueza produzida no país (BRASIL, 2004).

A importante história vivenciada pelas populações afrodescendentes e indígenas no Brasil não é percebida nos livros didáticos em geral. O que ocorre é que, embora seja visível a contribuição dos negros, pardos e índios na construção e formação da sociedade brasileira, há um foco etnocêntrico marcadamente de raiz europeia nos currículos escolares.

Este artigo tem como objetivo refletir sobre o desenvolvimento da história e cultura afro-brasileira e indígena nos livros didáticos da disciplina de História do Ensino Médio. Assim, o tema está relacionado à Lei $n^{\circ} 11.645 / 2008$, a qual estabelece a obrigatoriedade da temática história e cultura afro-brasileira e indígena no currículo oficial da rede de ensino, seja em estabelecimentos de Ensino Fundamental, seja naqueles que têm Ensino Médio.

O tema do presente artigo é relevante, pois diz respeito à oportunidade de analisar o modo pelo qual a história e cultura afro-brasileira e indígena estão sendo inseridas nos livros didáticos, em especial após mais de 10 anos de implementação da Lei $n^{\circ} 11.645 / 2008$ nos currículos dos estabelecimentos de Ensino Fundamental e de Ensino Médio. Além disso, abordar o tema em questão visa valorizar a história e a cultura do povo negro e indígena nos currículos escolares, com vistas a reparar danos que se referem à sua identidade e aos seus direitos. Por fim, desenvolver uma discussão em torno do tema contribui para formar cidadãos que se identifiquem com uma sociedade multicultural e pluriétnica (BRASIL, 2004).

Para analisar a temática da história e cultura afro-brasileira e indígena nos livros didáticos, o tipo de pesquisa desenvolvido neste artigo foi bibliográfico. Além disso, foram examinados dois livros didáticos de História destinados ao $1^{\circ}$ ano do Ensino Médio, cuja seleção baseou-se na análise de um livro antes da implementação da Lei $n^{\circ} 11.645 / 2008$ e um livro depois da referida lei. Nesse caso, foram examinados

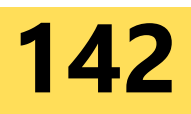


os livros Nova História Integrada: ensino médio (volume único) (FERREIRA; FERNANDES, 2005) e História: passado e presente (volume 1) (AZEVEDO; SERIACOPI, 2016), com o objetivo de verificar a abordagem da história e cultura afro-brasileira e indígena nos mesmos.

Quanto aos procedimentos metodológicos, salienta-se que a escolha dos dois livros didáticos, ou seja, Nova História Integrada: ensino médio (FERREIRA; FERNANDES, 2005) e História: passado e presente (AZEVEDO; SERIACOPI, 2016), se deu por amostragem não-probabilística, a qual não apresenta fundamentação matemática ou estatística, dependendo somente de critérios do pesquisador (GIL, 2008). Assim, o critério utilizado aqui baseou-se na análise de um livro antes da implementação da Lei $n^{\circ}$ 11.645/2008 e um livro depois da referida lei.

Além disso, utilizou-se de fontes documentais advindas de registros escritos fornecidos por instituições governamentais, a exemplo da Lei $n^{\circ} 11.645 / 2008$ e de relatórios elaborados por agências do governo, tais como o Ministério da Educação, a Secretaria de Educação Básica, o Conselho Nacional de Educação, etc.

Para a análise dos livros didáticos, estabeleceu-se três dimensões de análise. Na primeira dimensão, buscou-se verificar a construção de reflexões críticas sobre a história e cultura afro-brasileira e indígena. A segunda examinou a produção de textos analíticos acerca da temática história e cultura afro-brasileira e indígena. Por fim, na terceira dimensão de análise, investigou-se o foco dado em torno do tema relativo à diversidade cultural, racial e social do Brasil. O Quadro 1 apresenta as dimensões de análise propostas no artigo.

Quadro 1 - Dimensões de análise propostas para a análise dos livros didáticos

\begin{tabular}{|c|c|}
\hline 1 & Construção de reflexões críticas sobre a história e cultura afro-brasileira e indígena \\
\hline 2 & $\begin{array}{l}\text { Produção de textos analíticos acerca da temática história e } \\
\text { cultura afro-brasileira e indígena }\end{array}$ \\
\hline 3 & Foco dado em torno do tema relativo à diversidade cultural, racial e social do Brasil \\
\hline
\end{tabular}

Fonte: Elaboração própria.

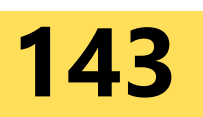


Além desta introdução, o artigo apresenta a Lei no 11.645/2008, trazendo antes do dispositivo legal, as disparidades sociais entre brancos, negros e índios no Brasil. Em seguida, é apresentada a seção relativa à utilização do livro didático em sala de aula. Logo após, é abordada a análise da temática nos dois livros didáticos de História do Ensino Médio. Por fim, apresenta-se as considerações finais do presente artigo.

\section{DISPARIDADES SOCIAIS NA SOCIEDADE BRASILEIRA CONTEMPO- RÂNEA E A LEI N 11.645/2008}

As disparidades entre brancos, negros e índios no Brasil contemporâneo são evidentes. Ao se analisar mais profundamente a sociedade brasileira, nota-se que os afrodescendentes e os indígenas integram, em sua grande maioria, as populações de baixa renda, bem como os segmentos discriminados, marginalizados e vulneráveis socialmente.

Para quem não é afeito ao recorte de raça/cor, as estatísticas, a exemplo das publicadas pelo Instituto Brasileiro de Geografia e Estatística (IBGE), relativas à renda, escolaridade, mercado de trabalho, violência, representação política, condições de moradia, etc., mostram que há sim disparidades entre brancos, negros e indígenas. Dados do IBGE, em 2019, a respeito de indicadores sociais da população preta e parda mostram que (NEXO JORNAL, 2020):

- 13,5 milhões de brasileiros que vivem em extrema pobreza, $75 \%$ são pretos e/ou pardos. Segundo o estudo, quanto mais pobre é a faixa da população, maior é a porcentagem negra;

- pretos e pardos fazem maior uso de transporte público, estão em um número maior de pessoas morando em um mesmo domicílio e falta a essa população saneamento básico e acesso a serviços de saúde;

- 67\% da população negra brasileira depende do SUS;

- há uma proporção maior de pessoas de cor preta e parda em ocupações informais, totalizando $47,3 \%$ das pessoas ocupadas. Em comparação, brancos nessa categoria de trabalho correspondem a $34,6 \%$ do total da população ocupada.

No que se refere aos índios, o Censo do IBGE (2010) mostra que o total dos 305 povos indígenas somam 896.917 pessoas. Desse contingente, 324.834 vivem em espaços urbanos e 572.083 em áreas rurais, correspondendo a $0,47 \%$ da população total do país (INSTITUTO SOCIOAMBIENTAL, 2020). 
Quanto à renda, os povos indígenas apresentam um rendimento médio menor em comparação com os demais grupos de cor ou raça. Segundo o estudo de Arruti e Dowbor (2014), no espaço urbano, os indígenas possuíam um

[...] rendimento médio total de $\mathrm{R} \$ 600,89$, um pouco acima do valor médio observado entre as pessoas de cor ou raça preta $(R \$ 582,70)$, mas bem inferior aos rendimentos médios mensais dos brancos ( $R \$ 1538)$ e amarelos $(R \$ 1$ 574) (IBGE, 2012: 51). Já na área rural, com a maioria dos indígenas vivendo em Tl's [Terras Indígenas], o rendimento médio é, como o esperado bastante inferior: R\$ 142,22, se comparado com o urbano (ARRUTI; DOWBOR, 2014, p. 19-20).

Ao analisar os dados sobre acesso à rede de esgoto, seja no meio urbano, seja no meio rural, enquanto $74,5 \%$ dos domicílios urbanos brasileiros possuíam rede de esgoto em seus domicílios, apenas 42,2\% dos domicílios em Terras Indígenas (Tl's) de áreas urbanas estavam nesta condição. No meio rural, 16,6\% dos domicílios possuem rede geral de esgoto, ao passo que 12,5\% dos domicílios localizados em Tl's tinham acesso ao esgoto (ARRUTI; DOWBOR, 2014).

Após esta breve análise sobre os indicadores sociais da população negra e indígena, é notável a necessidade de políticas específicas que revertam o quadro. A Lei $n^{\circ} 11.645 / 2008$ se insere no âmbito das políticas públicas de reparações voltadas para negros e índios e busca oferecer uma resposta para reparar, reconhecer e valorizar a história, cultura e identidade das populações afrodescendentes e dos povos indígenas (BRASIL, 2004).

A referida lei foi modificada e retirada da Lei $n^{\circ} 10.639 / 2003$, a qual previa somente a obrigatoriedade da temática "História e Cultura Afro-Brasileira". Assim, a Lei $\mathrm{n}^{\circ} 11.645 / 2008$ passou a ter a seguinte redação:

[...] "Art. 26-A. Nos estabelecimentos de ensino fundamental e de ensino médio, públicos e privados, torna-se obrigatório o estudo da história e cultura afro-brasileira e indígena.

$\S 1^{\circ} \mathrm{O}$ conteúdo programático a que se refere este artigo incluirá diversos aspectos da história e da cultura que caracterizam a formação da população brasileira, a partir desses dois grupos étnicos, tais como o estudo da história da África e dos africanos, a luta dos negros e dos povos indígenas no Brasil, a cultura negra e indígena brasileira e o negro e o índio na formação da sociedade nacional, resgatando as suas contribuições nas áreas social, econômica e política, pertinentes à história do Brasil.

$\S 2^{\circ}$ Os conteúdos referentes à história e cultura afro-brasileira e dos povos indígenas brasileiros serão ministrados no âmbito de todo o currículo escolar, em especial nas áreas de educação artística e de literatura e história brasilei- 
De acordo com Marques (2019), a lei é proveniente de amplas discussões e lutas das populações afrodescendentes e povos indígenas na busca por sua valorização e respeito às diferenças e diversidades raciais, étnicas, culturais e linguísticas, bem como por sua autoafirmação na sociedade brasileira. No entanto, segundo a autora, a lei - que também integra o art. 26-A da Lei de Diretrizes e Bases da Educação Nacional (LDB) - deve ir além da simples inclusão de conteúdos programáticos novos nos currículos e disciplinas como Literatura, Educação Artística e História.

Para ela, a lei na prática deve não apenas mudar o foco etnocêntrico de raiz europeia para um africano ou indígena, como também ampliar os currículos escolares e a formação docente, a fim de que se possa abranger a diversidade cultural brasileira e possibilitar a educação das relações étnico-raciais nos espaços escolares e nos currículos de um modo geral. Segundo Marques (2019, p. 29),

[...] para que o tratamento das temáticas abordadas pela Lei $\mathrm{n}^{\circ} 11.645 / 2008$ possa ocorrer de maneira efetiva, os sistemas de ensino, os professores e todos os responsáveis pela sua implementação devem buscar não só ter conhecimento sobre a ERER [Educação das Relações Étnico-Raciais], mas superar os principais problemas que impedem sua efetivação e que acabam por reforçar preconceitos e produzir desinformação sobre os povos indígenas e afro-brasileiros.

Ainda assim, a aprovação da Lei $n^{\circ} 11.645 / 2008$, além de outras normas, passou a ser uma das grandes conquistas alcançadas pelo movimento negro e pelo movimento indígena no Brasil. Contudo, no que se refere à implantação e implementação da referida lei, há que se reconhecer o desafio aos estabelecimentos de ensino, especialmente no que tange à formação de docentes e à organização das matrizes curriculares, em uma abordagem multidisciplinar, interdisciplinar e transdisciplinar (MARQUES, 2019).

A próxima seção apresenta reflexões sobre a utilização do livro didático em sala de aula. A produção de materiais didáticos voltados à temática da história dos povos indígenas e das populações afrodescendentes apresenta dificuldades para a sua correta inclusão nos currículos das escolas da Educação Básica. É o que será abordado a seguir. 


\subsection{A UTILIZAÇÃO DO LIVRO DIDÁTICO EM SALA DE AULA}

Segundo Avelar (2012), a utilização do livro didático em sala de aula, com seus limites, contradições e potencialidades, é bastante debatido entre pedagogos e professores. Há uma diversidade de posicionamentos em disputa quando se trata dos livros didáticos, sobretudo quando se analisa, por exemplo, os "pacotes educacionais" que visam transformar o espaço da escola em um simples mercado lucrativo ou o caráter ideológico da obra didática.

De acordo com Munakata (2012, p. 58), o livro didático é "[...] o livro produzido para fins educacionais, visando principalmente ao público escolar." Como pontua o autor, o livro didático e a escola mantêm um vínculo muito forte. Nos séculos XVIII e XIX, essa relação simbiótica tornou-se mais importante devido à emergência, à consolidação e ao fortalecimento dos Estados nacionais, posto que a educação escolar passou a ser direito dos cidadãos e, ao mesmo tempo, obrigação do Estado.

Ademais, foram estabelecidos os princípios de um ensino público, gratuito, laico e obrigatório, além de ter sido formulado, em alguns países, conteúdos programáticos curriculares unificados para toda a nação. Por exemplo, no decorrer da Revolução Francesa existia uma preocupação de formar um novo homem, cujo passado ligado aos vícios do Antigo Regime ${ }^{63}$ deveria ser abandonado. Buisson (1887, p. 1605), citado por Munakata (2012, p. 60), afirma que

Quando os homens da Revolução trataram de criar um sistema nacional de instrução pública, uma de suas principais preocupações foi a redação de livros elementares destinados para pôr ao alcance dos alunos das escolas primárias e secundárias, assim como dos cidadãos desejosos de se instruir, os conhecimentos indispensáveis a todos os homens.

No Brasil, a relação entre o Estado e os livros didáticos é feita por meio do Programa Nacional de Livro Didático (PNLD). Criado em meados dos anos 1980, o governo compra os livros solicitados pelos docentes a fim de serem distribuídos aos alunos das escolas públicas. Atualmente, os livros, produzidos pelas editoras, devem se adequar às inúmeras exigências governamentais, as quais estão postas nos Parâmetros Curriculares Nacionais (PCNs), nas Diretrizes Curriculares Nacionais (DCNs) e nos dispositivos específicos de cada edital do PNLD, etc. (MUNAKATA, 2012).

63 Antigo Regime é o nome dado ao sistema político e social da França anterior à Revolução Francesa (1789). 
O autor ressalta que, como produto de um simples mercado lucrativo - a exemplo de outros espaços em que transações de compra e venda ocorrem -, o livro didático é uma mercadoria, que carrega consigo todos os vícios do capitalismo. Sendo altamente lucrativos para as editoras, os livros didáticos são reduzidos à sua forma mercantil como qualquer outra mercadoria. Munakata (2012, p. 63) salienta que

[...] Saco de batata, refrigerante, serviço odontológico, automóvel, passagem
aérea, livro didático, camiseta, eletrodomésticos, livro de Marx, de Adorno,
de Hayek ou de pornografia, chácara, filme, ingresso para um concerto de
Beethoven ou Berg, caneta, porta-retrato, tudo, tudo que possa ser vendido e
comprado, tudo é esse ser-para-o-lucro e possibilita a produção e a reprodu-
ção da sociedade capitalista.

Percebe-se que, no caso do livro didático, para que ele seja considerado uma mercadoria há o trabalho concreto e efetivo de inúmeras pessoas, ou seja, o autor, o editor, o chefe de arte, o preparador de texto, o divulgador, o avaliador, o professor, o aluno, entre outras pessoas necessárias à sua conclusão. Assim, a produção do livro didático serve para a acumulação do capital, o qual satisfaz as necessidades de fins educacionais (valor de uso), mas, com o objetivo de realizar a satisfação dessas necessidades, subordina-se ao valor de troca e às suas determinações ${ }^{64}$.

Quanto ao caráter ideológico dos livros didáticos, Avelar (2012) afirma que diversos estudos sobre o tema são realizados a fim de que se conheça os mecanismos de propagação de preconceitos, visões de mundo dos grupos dominantes, falsas consciências, entre outros. No entanto, é evidente que a ideologia é inerente às obras didáticas, uma vez que é um dos dispositivos do "[...] aparelho escolar, locus privilegiado de difusão ideológica." (AVELAR, 2012, p. 116).

Para o autor, o livro didático tem assumido um papel cada vez maior frente ao despreparo de boa parte dos professores e a ausência de políticas públicas voltadas à formação docente. O que ocorre é que a obra didática tem orientado o ensino, "[...] oferecendo tanto ao aluno quanto ao professor um texto programado, fechado e normativo. Resulta daí que a obra didática homogeneíza os docentes, reservando-Ihes um papel de simples manipuladores de textos e manuais" (AVELAR, 2012, p. 116).

$64 \quad$ Fundamentando-se em Marx, Munakata (2012) afirma que, em um regime baseado na troca, o valor de uso da mercadoria, que se refere à sua utilidade para satisfazer essas necessidades, aparece também como suporte material do valor de troca, pelo qual as mercadorias são trocadas no mercado. 
Embora haja na disciplina de História, conforme o autor, um avanço na inserção de temas como multiculturalismo, história local e imaginário nos livros didáticos, é notório que, no Brasil, ainda convivem

[...] de maneira tensa, a cultura e o padrão estético negro e africano e um padrão estético e cultural branco europeu. Porém, a presença da cultura negra e o fato de $45 \%$ da população brasileira ser composta de negros (de acordo com o censo do IBGE) não têm sido suficientes para eliminar ideologias, desigualdades e estereótipos racistas. Ainda persiste em nosso país um imaginário étnico-racial que privilegia a brancura e valoriza principalmente as raízes européias (sic) da sua cultura, ignorando ou pouco valorizando as outras, que são a indígena, a africana, a asiática (BRASIL, 2004, p. 14).

Daí a necessidade de estudar o tema relativo à história e cultura afro-brasileira e indígena nos livros didáticos de História, pois é através destes que as atividades propostas e os encaminhamentos de atividades a serem feitas pelos alunos são desenvolvidas.

\section{A LEI N $11.645 / 2008$ NOS LIVROS DIDÁTICOS DE HISTÓRIA: UMA ANÁLISE}

O livro didático Nova História Integrada: ensino médio (volume único), publicado em 2005, tem como autores João Paulo Hidalgo Ferreira e Luiz Estevam de Oliveira Fernandes, bem como colaboradores Marcos Vinícius de Morais e Anderson Roberti dos Reis. A capa do livro apresenta três imagens, as quais podem ser classificadas como abrangentes e tradicionais, uma vez que não traz nenhuma referência à temática afro-brasileira e indígena.

Descrevendo o livro, percebe-se que ele está dividido em 43 capítulos, os quais abordam conteúdos de História que vão do $1^{\circ}$ ano ao $3^{\circ}$ ano do Ensino Médio (EM). Com o objetivo de verificar a abordagem da história e cultura afro-brasileira e indígena neste livro, este artigo abrangeu em sua análise até o capítulo 10, visto que é até esta parte que o conteúdo de $1^{\circ}$ ano do EM é tratado. Tal escolha se deu tendo em vista que o outro livro didático - o qual será apresentado no texto que segue - é de $1^{\circ}$ ano somente.

Dentre os 10 (dez) capítulos, o capítulo 10, cujo título é Uma História da África, mostra a temática relativa ao continente africano em nove (9) páginas e meia. Já a temática indígena é abordada dentro do capítulo 9 intitulado de O Novo Mundo, a qual divide o capítulo com os temas da América pré-colombiana, bem como com os conteúdos relacionados às civilizações asteca, maia e inca. Esta temática é tratada em três (3) páginas e meia. 
Analisando o capítulo 10, percebe-se que esta parte está dividida com os seguintes itens: apresentação da diversidade e pluralidade do continente africano; as cidades e a organização política da África até o século XIV; os contatos com as três grandes religiões monoteístas (judaísmo, cristianismo e islamismo); a organização política no oriente e no ocidente da África; o continente africano antes das chegadas dos europeus; a escravidão e os tráficos de escravos na África.

Quase ao final do capítulo, é apresentada uma proposta de leitura e atividade sobre o conceito de escravidão. Já no final do capítulo propriamente, é mostrada uma cronologia da África, além de um resumo do que foi visto. Há também uma seção de sugestão de livros, filmes e sites, onde o tema tratado no capítulo pode ser buscado. Por fim, são propostos dez (10) exercícios, com questões dissertativas e de múltipla escolha, para aprofundar o conteúdo abordado.

No PNLD de 2008, menciona-se que o livro possui "o capítulo sobre História da África, com problematização de seus elementos conceituais e históricos [...]", foi apreciado de forma positiva (BRASIL, 2007, p. 108). Contudo, há alguns pontos a se ressaltar. O primeiro deles é que o capítulo apresentou imagens imprecisas em sua editoração, além de serem de difícil interpretação, dificultando ao aluno o interesse pelo tema. Um segundo ponto é que há um excesso de mapas (3), os quais poderiam ser substituídos por textos que trouxessem discussões que fizessem relação entre passado e presente.

Examinando o capítulo a partir das três dimensões de análise descritas na seção Metodologia, observa-se que o mesmo não aborda, por exemplo, a história dos povos e culturas africanas. Há uma prioridade nos aspectos políticos e religiosos do continente africano, além de trazer à pauta a questão da escravidão e do tráfico de escravos, assunto tratado de forma tradicional em boa parte dos livros de História, sobretudo os mais antigos. Assim, depreende-se que o modo como o tema é tratado no capítulo não visa trazer reflexões críticas sobre a história e cultura afro-brasileira e africana.

Ademais, não há textos analíticos sobre a história e cultura afro-brasileira e africana que pudessem despertar o interesse dos alunos sobre a temática. Nota-se ainda que não é abordada a diversidade cultural, racial e social do Brasil ou, ainda, o legado cultural que os povos africanos deixaram no país, a exemplo da linguagem, 
música, culinária, dança, etc. Posto isso, fica evidenciado que o desenvolvimento da história e cultura afro-brasileira e africana possui um lugar secundário na perspectiva dos autores do livro.

No que se refere à temática indígena, não há um capítulo específico para tratar do assunto. Nas partes relativas ao tema, as quais constam no capítulo 9, nota-se que os autores o desenvolveram com os seguintes itens: a apresentação dos índios que habitavam o Brasil; os grupos indígenas; a antropofagia; as alianças entre indígenas e portugueses.

Ao final do capítulo 9, não há uma cronologia específica para os povos indígenas. Na seção de sugestão de livros, filmes e sites, há várias sugestões tratando do tema indígena. Por fim, são propostos dez (10) exercícios, com questões dissertativas e de múltipla escolha, no entanto, apenas dois (2) deles são sobre o assunto.

Em comparação com a história e cultura afro-brasileira e africana, a questão indígena foi pouco abordada no livro. Além disso, ao examinar essas partes com base nas três dimensões de análise detalhadas na seção Metodologia, percebe-se que não há o desenvolvimento da história e cultura dos povos indígenas, nem há textos analíticos que levem o aluno a buscar informações sobre os povos indígenas. Por fim, a contribuição dos índios para a diversidade cultural, racial e social do Brasil também não é apresentada no capítulo.

Cabe ressaltar que o tratamento da temática indígena no capítulo é tradicional e acaba por provocar "[...] a reprodução de estereótipos e preconceitos tradicionalmente utilizados contra os povos indígenas [...]" (BRASIL, 2015, p. 6), como é o caso de mencionar a questão da antropofagia. Na verdade, há problemas relacionados à representação dos povos indígenas no imaginário social brasileiro, os quais também perpassam a produção dos livros didáticos em geral.

Veja-se o que o parecer do Conselho Nacional de Educação sobre as Diretrizes Operacionais para a implementação da história e das culturas dos povos indígenas na Educação Básica, em decorrência da Lei n 11.645/2008, realizado em 2015, pondera sobre como os povos indígenas são percebidos no Brasil. Nesse caso, há uma

[...] • reificação da imagem do indígena como um ser do passado e em função do colonizador;

- apresentação dos povos indígenas pela negação de traços culturais (sem escrita, sem governo, sem tecnologias); 
- omissão, redução e simplificação do papel indígena na história brasileira;

- adoção de uma visão e noção de índio genérico, ignorando a diversidade que sempre existiu entre esses povos;

- generalização de traços culturais de um povo para todos os povos indígenas;

- simplificação, pelo uso da dicotomia entre índios puros, vivendo na Amazônia versus índios já contaminados pela civilização, onde a aculturação é um caminho sem volta;

- prática recorrente em evidenciar apenas características pitorescas e folclóricas no trato da imagem dos povos indígenas;

- ocultação da existência real e concreta de povos indígenas particulares, na referência apenas "aos índios" em geral;

- ênfase no "empobrecimento" material dos estilos e modos de vida dos povos indígenas. (BRASIL, 2015, p. 6-7).

O documento ainda afirma que a elaboração, aquisição e distribuição de materiais didáticos "[...] devem conhecer e superar os principais problemas retro evidenciados, os quais somente reforçam preconceitos e produzem desinformações sobre os povos indígenas" (BRASIL, 2015, p. 7). Assim, no que se refere à análise do livro em questão, infere-se que o tratamento da história e cultura dos povos indígenas possui um lugar secundário na visão dos autores do livro.

O livro didático História: passado e presente, publicado em 2016, tem como autores Gislane Azevedo e Reinaldo Seriacopi. A capa do livro apresenta duas imagens, as quais foram referenciadas na folha de rosto do livro e mostram a vista de um sítio arqueológico, bem como a plataforma do Jaguar, no Templo de Kukulcan, e pirâmide Chichén-Itzá, ambas situadas na península de lucatã, no México. Embora as imagens não tragam nenhuma referência à temática afro-brasileira e indígena, elas não lembram as representações eurocêntricas comumente ilustradas em livros mais antigos de História.

O livro está dividido em 13 capítulos, o qual corresponde aos conteúdos do $1^{\circ}$ ano do Ensino Médio. Dentre as 13 partes da obra, o capítulo 10, intitulado de Reinos africanos, mostra a temática referente à história e cultura africana em 12 páginas. Quanto ao tema da história e cultura indígena, esta é abordada em uma página e meia $\left(1 \frac{1}{2}\right)$ na introdução do livro.

Ao analisar o capítulo 10, nota-se que esta parte encontra-se dividida com os seguintes itens: o continente africano; o Reino de Axum; os Reinos do Sahel; a Ci- 
vilização Iorubá; a Cultura banto. Em todo o capítulo, são apresentados trechos de textos, imagens e proposição de atividades que instiguem o aluno a refletir sobre a história da África. Merece destaque um boxe que faz uma interface entre o passado e o presente do continente africano. Ademais, no final do capítulo, são propostos sete (7) exercícios, com questões dissertativas e de múltipla escolha, sobre o tema.

Investigando o capítulo 10, apoiando-se nas três dimensões de análise descritas na seção Metodologia, observa-se que a história e a cultura dos povos africanos é devidamente abordada. O capítulo inicia trazendo a escritora nigeriana Chimamanda Adichie, que faz parte de uma geração de autores africanos que divulgam a história e a realidade do continente sob a perspectiva de seus habitantes.

Há também a proposição de textos analíticos sobre a história e cultura afro-brasileira e africana, a exemplo de um texto "O perigo de uma única história" de Chimamanda Adichie. O texto aborda os efeitos que uma narrativa única sobre a história da África e dos africanos, sempre a partir de uma perspectiva estrangeira, acaba por trazer uma visão inferiorizada do continente. Além disso, o texto ajuda o aluno refletir e desconstruir modelos hegemônicos de pensamento sobre a África.

É também apresentado o legado cultural que os povos africanos deixaram no país através das seções que falam das crenças dos povos africanos e a cultura dos povos iorubá e banto na sociedade brasileira. Por exemplo, dos iorubás, são mostradas a prática do culto aos orixás do candomblé (Xangô e lemanjá), o uso dos instrumentos musicais originários da África (atabaque e agogô), a introdução de pratos culinários como o vatapá e o acarajé. De parte dos bantos, são abordadas manifestações culturais como congadas, maracatus, simpatias, rezas, etc. Assim, nota-se que o desenvolvimento da história e cultura afro-brasileira e africana possui um lugar de destaque na perspectiva dos autores do livro.

Quanto à temática indígena, não há um capítulo específico para tratar do tema, mas ele apresenta algumas informações sobre a diversidade dos povos indígenas, a demarcação das Terras Indígenas, a importância da Fundação Nacional do Índio (Funai) e o desenvolvimento das políticas indigenistas no Brasil, como a elaboração do Estatuto do Índio, o reconhecimento dos direitos dos índios na Constituição Cidadã de 1988 , etc.

Embora apresente de forma reduzida a história e cultura dos povos indígenas

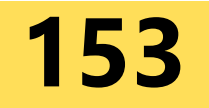


do Brasil, o livro mostra uma abordagem diferenciada sobre os costumes, conhecimentos e experiências indígenas do passado e do presente. Contudo, o exame das três dimensões restou prejudicada neste artigo, pois o livro de História do $1^{\circ}$ ano do Ensino Médio não desenvolve propriamente a questão indígena, abordando o tema nos volumes 2 e 3 da obra didática História: passado e presente.

\section{CONCLUSÃO}

Neste artigo, buscou-se analisar de que maneira a temática relacionada à história e cultura afro-brasileira e indígena proposta na Lei $n^{\circ} 11.645 / 2008$ foi desenvolvida em dois livros didáticos da disciplina de História no Ensino Médio. A opção de escolher uma obra anterior à lei e outra obra após a execução da referida lei permitiu investigar em que medida o estudo da história e cultura afro-brasileira e indígena vem sendo tratada nos materiais didáticos produzidos no âmbito da Educação Básica.

Este estudo mostrou que há diferenças nos dois livros analisados, uma vez que a obra anterior à Lei $n^{\circ} 11.645 / 2008$ abordou a história africana e indígena de forma tradicional, superficial e estereotipada, sobretudo nas partes relativas à temática dos povos indígenas. No que se refere ao capítulo 10, a abordagem quanto aos povos africanos é bastante econômica e política, não trazendo aspectos relativos às culturas africanas e ao legado desses povos no Brasil. Assim, concluiu-se que o tratamento da história e cultura dos povos africanos e indígenas possui um lugar secundário na visão dos autores do livro didático Nova História Integrada: ensino médio.

Já o livro História: passado e presente, o qual foi publicado após a Lei $\mathrm{n}^{\circ}$ 11.645/2008, desenvolve a temática da história e da cultura dos povos africanos e indígenas em conformidade com o que propõe o dispositivo legal, em especial no que tange à história e cultura africana. No capítulo 10 do livro, Reinos Africanos, os autores conseguiram trazer uma perspectiva diferente da África, dando destaque às culturas iorubá e banto, às crenças religiosas dos africanos, ao legado desses povos na sociedade brasileira, etc.

Quanto à temática indígena - embora pouco descrita no livro, já que é abordada no volume 2 do livro História: passado e presente -, nota-se que o conteúdo apresenta um ponto de vista que traz a ideia de um reconhecimento, valorização e respeito dos e pelos povos indígenas. Desse modo, concluiu-se que o desenvolvi-

\section{4}


mento da história e cultura afro-brasileira e africana, bem como indígena possui um lugar de destaque na perspectiva dos autores do livro.

Por fim, um elemento que merece destaque é que o artigo traz importantes reflexões sobre a inclusão da história e cultura afro-brasileira, africana e indígena nos currículos da Educação Básica, além de versar sobre como os livros didáticos são utilizados nas salas de aula. Recomenda-se que o tema deste artigo seja desenvolvido em outras análises, a fim de que se possa mensurar a abordagem de temáticas relacionadas à cultura e à história dos negros e dos índios nos livros didáticos de História do Ensino Médio.

\section{REFERÊNCIAS}

ARRUTI, J. M.; DOWBOR, M. Desigualdades étnico-raciais no Brasil: análise dos povos indígenas e das comunidades quilombolas. Trabalho técnico. São Paulo CEBRAP, 2014. Disponível em: <http://professor.ufrgs.br/dagnino/files/relatorio_texto_final_cebrap_16junho2014_def.pdf> Acesso em: 12 jun. 2020.

AVELAR, A. S. Os desafios do ensino de História: problemas, teorias e métodos. Curitiba: InterSaberes, 2012.

AZEVEDO, G.; SERIACOPI, R. História: passado e presente. Volume 1. São Paulo: Ática, 2016.

BRASIL. Diretrizes Curriculares Nacionais para a Educação das Relações Étnico-Raciais e para o Ensino da História e Cultura Afro-brasileira e Africana. Brasília: MEC, 2004. Disponível em: <http://portal.inep.gov.br/informacao-da-publicacao/-/asset_publisher/6JYIsGMAMkW1/document/id/488171>. Acesso em: 9 abr. 2020.

História: catálogo do Programa Nacional do Livro para o Ensino Médio: PNLEM/2008. Secretaria de Educação Básica, Fundo Nacional de Desenvolvimento da Educação. Brasília: Ministério da Educação, Secretaria de Educação Básica, 2007. Disponível em: <http://www.fnde.gov.br/index.php/centrais-de-conteudos/publicacoes/category/125-guias?download=7577:pnlem-2009-historia> Acesso em: 08 mai. 2020.

Lei $n^{\circ} 11.645$. Altera a Lei $n^{\circ} 9.394$, de 20 de dezembro de 1996, modificada pela Lei $n^{\circ} 10.639$, de 9 de janeiro de 2003, que estabelece as diretrizes e bases da educação nacional, para incluir no currículo oficial da rede de ensino a obrigatoriedade da temática "História e Cultura Afro-Brasileira e Indígena". Diário Oficial da Re-

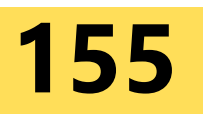


pública Federativa do Brasil, Brasília, 2008. Disponível em: <http://www.planalto. gov.br/ccivil_03/_Ato2007-2010/2008/Lei/L11645.htm> Acesso em 01 mai. 2020.

. Parecer CNE/CEB No: 14/2015. Conselho Nacional de Educação/Câmara de Educação Básica (CNE/CEB). Diretrizes Operacionais para a implementação da história e das culturas dos povos indígenas na Educação Básica, em decorrência da Lei $n^{\circ}$ 11.645/2008. Brasília, 2015. Disponível em: <http://portal.mec.gov. br/index .php?option=com_docman\&view=download\&alias $=27591$-pareceres-da-camara-de-educacao-basica-14-2015-pdf\&ltemid=30192 > Acesso em 27 mai. 2020.

FERREIRA; J. P. H.; FERNANDES, L. E. O. Nova História Integrada: ensino médio. Vol. único. Campinas, SP: Companhia da Escola, 2005.

GIL, A. C. Métodos e técnicas de pesquisa social. 6. ed. São Paulo: Atlas, 2008.

IBGE. Censo Demográfico - 2010: Características da população e dos domicílios. Resultados do universo. Rio de Janeiro: IBGE, 2011. Disponível em: <http://portal. mj.gov.br/sedh/rndh/Carta\%20do\%20Rio.pdf>. Acesso em: 20 mai. 2020.

INSTITUTO SOCIOAMBIENTAL. Quantos são?: povos indígenas no Brasil. Disponível em: <https://pib.socioambiental.org/pt/Quantos_s\%C3\%A30\%3F> Acesso em 24 jun. 2020.

MARQUES, M. A formação no curso de pedagogia após a aprovação da Lei $\mathbf{n}^{\circ}$ 11.645/2008: estudo de caso - Universidade Regional Integrada do Alto Uruguai e das Missões (URI). 2019. Tese (Doutorado). Programa de Pós-Graduação em Educação. Universidade do Vale do Rio dos Sinos, São Leopoldo, RS, 2019.

MUNAKATA, K. O livro didático como mercadoria. Pró-Posições (UNICAMP. Impresso), v. 23, p. 51-66, 2012.

NEXO JORNAL. O impacto do racismo estrutural nas mortes por covid-19. Disponível em: <https://www.nexojornal.com.br/expresso/2020/04/15/O-impacto-do-racismo-estrutural-nas-mortes-por-covid-19>. Acesso em: 29 abr. 2020. 


\section{A HISTORIA LOCAL E A PESQUISA EM HISTORIA DA EDUCAÇÃO: UMA ANALISE DOCUMENTAL DA INSTRUÇÃO PÜBLICA DA PROVINCIA MARANHENSE}

Ricardo Costa de Sousa ${ }^{65}$

65 Pós-doutorando em Educação pela Universidade do Oeste de Santa Catarina (UNOESC). Doutore Mestre em Educação pela Universidade Federal do Rio Grande do Sul (UFRGS). Especialista em Gestão de Políticas Públicas em Gênero e Raça pela Universidade Federal do Maranhão (UFMA). Pedagogo pela Faculdade de Educação Santa Teresinha (FEST). Militante do Centro de Cultura Negra Negro Cosme (CCNNC) em Imperatriz (MA). E-mail: ricardo_lut@hotmail.com 


\section{INTRODUÇÃo}

O presente texto procura discutir A HISTÓRIA LOCAL E A PESQUISA EM HISTÓRIA DA EDUCAÇÃO: UMA ANÁLISE DOCUMENTAL DA INSTRUÇÃO PÚBLICA DA PROVIÍNCIA MARANHENSE. Tal discussão possibilita abordar sobre a Instrução Pública no município de Alcântara, Estado do Maranhão entre os anos de 1825 a 1841. Cabe dizer que este texto se insere no campo da História da Educação sob a perspectiva da História Cultural.

Para as historiadoras Maria Stephanou e Maria Helena Camara Bastos, no livro Histórias e memórias da educação no Brasil (2011), dizem que a História da Educação é um campo "multifacetado e pluridisciplinar", que "abarca vários temas e objetos de pesquisa". Nesse sentido, pesquisar os documentos acondicionados no Arquivo Público do Estado do Maranhão (APEM) possibilitou um olhar acurado sobre a instrução em Alcântara.

Sob os aspectos metodológicos, tomou-se as contribuições de Pesavento (2005, p. 42), quando registra que, a História Cultural seria, pois, decifrar a realidade do passado por meio das suas representações, tentando chegar àquelas formas, discursivas e imagéticas, pelas quais os homens expressaram a si próprios e o mundo. Na mesma linha de abordagem a autora (2005, p. 42) complementa dizendo que "torna-se claro que este é um processo complexo, pois o historiador vai tentar a leitura dos códigos de um outro tempo, que podem se mostrar, por vezes, incompreensíveis para ele, dados os filtros que o passado interpõe.

Desse modo, o grande desafio da História Cultural é descortinar o que fora silenciado pelos documentos historiográficos; aqui, indícios que marquem a presença da população negra nas escolas de instrução pública no município de Alcântara. Na busca por esses indícios, buscaram-se no acervo documental do Arquivo Público do Estado do Maranhão (APEM) indícios que possibilitassem captar o movimento da Educação em Alcântara, sobretudo, da população negra deste município, estabelecendo uma relação imbricada dos documentos com a teoria que, a esse respeito, Nunes e Carvalho (2005, p. 37) ressalta sobre a potência e riqueza do diálogo dos documentos com as teorias, "portanto, a possibilidade de, além de problematizar a ambas, alterar as representações que temos não só delas, mas também da própria

\section{8}


pesquisa histórica". Isso porque, para a autora (2005, p. 37), torna-se evidente que "tais representações não são apenas criações do espírito, mas produto da mentalidade de uma certa época, de certas categorias sociais e de determinados grupos".

O referido diálogo entre os documentos e a teoria possibilita descortinar e/ou apresentar alguns indícios para uma revisão historiográfica, como também, contribuir para a História da Educação no que diz respeito à instrução pública em Alcântara, especialmente, a escolarização da população negra, ou até mesmo a história da educação da população negra. Nesse intuito, realizou-se uma extensa investigação em documentos acondicionados no APEM sob o título: Secretaria do Governo "Instrução Pública" e "Câmara Municipal". As informações seguem em alguns mapas de matrícula e mapas de frequência de alunos/as das classes de primeiras letras, com entradas compreendidas entre os anos de 1825 a 1841.

\section{HISTORICIZANDO A INSTRUÇÃO PÚBlicA NO MUNICÍPIO DE ALCÂNTARA}

Primeiramente, faz-se necessário referenciar à Constituição do Império outorgada em 25 de março de 1824, que destacava no Art. 179, parágrafo 32, no qual cabia à educação a seguinte incumbência: "A instrução primária é gratuita para todos os cidadãos". Para dar conta da referida lei no que tange à instrução nacional, principalmente os dois primeiros meses de 1826 foram fecundos em reclamações e iniciativas em prol da instrução popular (BRASIL. 1824). A referida Lei de 15 de outubro de 1827 determinava:

Art. $1^{\circ} \mathrm{Em}$ todas as cidades, vilas e lugares mais populosos, haverá as escolas de primeiras letras que forem necessárias. Art. $4^{\circ}$ As escolas serão do ensino mútuo nas capitais das províncias; e serão também nas cidades, vilas e lugares populosos delas, em que for possível estabelecerem-se. Art. $6^{\circ}$ Os professores ensinarão a ler, escrever, as quatro operações de aritmética, prática de quebrados, decimais e proporções, as noções mais gerais de geometria prática, a gramática de língua nacional, e os princípios de moral cristã e da doutrina da religião católica e apostólica romana, proporcionados à compreensão dos meninos; preferindo para as leituras a Constituição do Império e a História do Brasil. Art. $11^{\circ}$ Haverá escolas de meninas nas cidades e vilas mais populosas, em que os Presidentes em Conselho, julgarem necessário este estabelecimento (BRASIL, 1824).

O relatório de Lino Coutinho, Ministro do Império de 1831 a 1836, denunciava os poucos resultados da implantação da lei de 1827, mostrando o mau estado do 
ensino elementar no país. Ele argumentava que os responsáveis pelos resultados insatisfatórios eram as municipalidades, os professores e os alunos, pela ineficiente administração e fiscalização, por desleixo e vadiagem, respectivamente, alegando os gastos e esforços do Estado no estabelecimento e ampliação desse ensino (GUIMARÃES CARVALHO, 2009). Segundo Bastos (2005, p. 42):

A implantação do Decreto 1827 esbarrou em uma série de obstáculos: a falta de adequados prédios escolares e materiais necessários à adoção do método mútuo; o descontentamento dos mestres, pela falta de proteção dos poderes públicos e pela falta de recompensa pecuniária. Essa situação pode ser verificada através das recomendações dos Ministérios do Império aos Presidentes Províncias.

Pode-se dizer que houve, por parte do Poder Público, um completo descaso com relação ao provimento das escolas com recursos materiais, como edifícios públicos, livros didáticos e demais itens necessários para a aplicação do método exigido por lei. Enfim, a referida lei não assumiu sua incumbência em "instruir seu povo", especialmente, a população negra.

A instrução pública no Império foi caracterizada por uma sociedade em ascendência da legitimação dos saberes escolares, em que a funcionalidade dos saberes elementares como "escrita, leitura e aritmética" era cada vez mais exigida como condição básica, de modo que essa funcionalidade foi encontrada a partir dos documentos da Secretaria do Governo - Câmara Municipal/ Instrução Pública.

Na Secretaria do Governo - Câmara Municipal de Alcântara foi possível encontrar informações acerca dos 33 alunos matriculados entre os anos de 1825 a 1832 que iniciaram seus estudos na Aula Nacional da llustríssima Câmara da Vila de Alcântara, pelo então professor João de Deos Soares de Mello. As observações contidas nesse mapa de matrícula são referentes à média de 19 faltas por aluno matriculado (ALCÂNTARA, 1832a, [s.p]). O documento esclarece que:

Faltas estas motivada por causa da maior parte dos alunos serem muito pobres, e serem obrigados, segundo a necessidade, de irem ajudar a seus pais desmancharem as suas rocinhas a fim de terem alguma farinha. Percorrem o campo atrás de caça para poderem se manter - como também, as faltas são motivadas por causa da moléstia [sarampo] (ALCÂNTARA, 1832a, [s.p]).

Observações como estas estão presentes em outros mapas ao longo do texto, nos quais se evidenciam o grande quantitativo de faltas motivadas por doenças ou 
por necessidade de ajudar os pais na lavoura. Portanto, o que se observa é a extrema pobreza vivenciada pelas famílias alcantarenses, dificultando a frequência escolar desses alunos, referenciados como "pobres".

A esse respeito, Veiga (2008, p. 06) afirma que: "para os estudos do século XIX podemos acrescentar a escola pública como um dos espaços de presença das crianças pobres e particularmente de produção da identificação 'aluno pobre'. Tal denominação pode ser detectada em diferentes documentos".

Cruz relata que o presidente da província, Eduardo Olímpio Martins, tinha uma preocupação quanto à instrução pública dos mais pobres e desvalidos; enfim, quanto a todas as classes de cidadãos. Entretanto, excluía os escravos, pois não eram considerados cidadãos, conforme determinou a legislação provincial (CRUZ, 2008).

Em 28 de janeiro de 1832, na Câmara Municipal, consta a lista de nomes e sobrenomes de 12 alunos que foram admitidos na aula particular do professor Ventura Henrique Ferreira entre os anos 1829 a 1832. Em observação escrita, o professor diz que o aluno "escreve cursivo, carta de sílabas, linhas e bastardo". Dessa forma, as observações contidas nesse mapa, como em muitos outros dizem respeito somente às formas de escritas (ALCÂNTARA, 1832c, [s.p]).

Em outro mapa, consta a relação de 13 alunos que frequentaram a escola particular de primeiras letras na vila de Alcântara sob a orientação do professor Manoel da Silva Maya, seguindo a mesma estrutura do mapa anterior, agora contendo informações relativas à doutrina, dizendo que os alunos sabem "até os mandamentos", "até o credo", "salve rainha" (ALCÂNTARA, 1838, [s.p]). Os dois mapas da escola particular e pública de Alcântara demonstram o modelo vigente de educação adotado em termos das classes de leitura, escrita, aritmética e doutrina. Faria Filho (2007, p. 139) assegura que:

Ao "ler, escrever e contar" agregaram-se outros conhecimentos e valores, que a instituição escolar deveria ensinar às novas gerações, sobretudo às crianças. Conteúdos como "rudimentos de gramática", de "língua pátria", de "aritmética" ou "rudimentos de conhecimentos religiosos", lentamente, aparecerão nas leis como componentes de uma "instrução elementar".

Era visível a incorporação de novos conteúdos ministrados nas escolas públicas, e as escolas particulares deveriam seguir a mesma proposta, conforme determinava a Regulamentação da Instrução Pública. Assim como as aulas particulares 
funcionavam na casa dos próprios professores, a escola pública também funcionava no espaço doméstico que era adaptado para essa finalidade. A esse respeito, Faria Filho (2007, p. 140) diz que:

Até então a escola que existia funcionava, na maioria das vezes, nas casas dos professores ou, sobretudo, nas fazendas, em espaços precários e, para o que nos interessa aqui, seguiam o método individual de ensino. Tal método consistia em que o professor, mesmo quando tinha vários alunos, acabava por ensinar a cada um deles individualmente. Na verdade, era o método por excelência da instrução doméstica, aquela que ocorria em casa, onde a mãe ensinava aos filhos e às filhas, ou os irmãos que sabiam alguma coisa ensinavam àqueles que nada sabiam.

Compartilha desse posicionamento Cruz (2008), quando diz que "as escolas particulares em geral funcionavam sob a regência de uma professora ou professor que lecionava, na maioria das vezes, também em sua própria residência". Escolas essas que eram fiscalizadas pelos delegados da inspetoria de instrução pública que, segundo o Art. $1^{\text {a }}$ do Regulamento de 1854, compreendia:

Realizar a "inspeção e fiscalização especial dos estabelecimentos públicos e particulares de ensino primário e secundário", ainda lhes compete segundo o "§ $1^{\text {a }}$. Impedir que se abra escola ou colégio sem preceder autorização para semelhante fim", e solicitar "dos professores, com especialidade o mapa mensal dos alunos das diversas casas de educação públicas, e o trimensal das particulares [...] juntando-lhes as observações e notas que lhes parecerem convenientes" (MARANHÃO, 1854).

Cabe dizer que, além desse Regulamento datado em 1854, houve outras determinações que exigiam das escolas a entrega de mapas e correlatos para a inspeção. Segundo Veiga (2008, p. 5), "Um expressivo conjunto de leis prescrevia a fiscalização das escolas, principalmente das aulas públicas, seja quanto ao trabalho dos professores, seja quanto ao aproveitamento dos alunos, gerando importante documentação da instrução pública".

Na pesquisa realizada por Cruz (2008), foi possível notar que a inspeção nas escolas particulares não era tão atuante como nas escolas públicas, pois, no que tange ao quantitativo de alunos, a inspeção era bastante rigorosa quanto ao limite para o funcionamento das escolas públicas.

Analisando a lista dos alunos que frequentavam a aula de Gramática Latina do professor Pedro Alves Serrão na Câmara Municipal de Alcântara, consta que todos os alunos ingressaram em 1831 e que tinham idades entre 12 e 18 anos. Referindo 
ao adiantamento desses alunos, o professor escreve: "tradução com alguma inteligência", mostrando que ao longo dos anos os alunos aprenderam significativamente a traduzir com inteligência textos solicitados. Contudo, cabe destacar uma observação de que "o estudante Vicente Cypriano Lima Barata só frequenta a Vila de tarde, tem pouco adiantamento por frequentar só de tarde em consequência de ocupação na Igreja Matriz" (ALCÂNTARA, 1831b, [s.p]). Logo, entende-se que o afastamento do estudante do espaço escolar é devido à necessidade de assegurar recursos para sua sobrevivência, assim como para sua família. Em relação a essa difícil situação vivenciada pelo estudante alcantarense, toma-se a contribuição de Veiga (2008, p. 06) ao dizer que:

A pobreza das famílias é apresentada como um elemento fundamental da infrequência ou da frequência irregular às aulas e, ao mesmo tempo, é um fator que inviabilizava a cobrança das multas, ocorrendo, portanto, o não cumprimento da lei. A pobreza é referida tanto pela falta de vestimentas para os meninos comparecerem à aula como pelo uso indiscriminado do trabalho infantil.

É importante ressaltar que a obrigatoriedade da frequência era para os meninos; contudo, apesar das determinações legais que previam sua frequência à escola, estas não foram precedidas de condições para a frequência regular dos alunos e, principalmente, para a aprendizagem daquilo que se esperava deles - o suficiente para se tornarem civilizados.

Uma interessante informação a ser mencionada é que, em 13 de abril de 1835, o professor Pedro Alves Serrão destacou: "saiu da Aula em $1^{\circ}$ de abril o Estudante Miguel Felgueira Lima, tendo em Latim o desenvolvimento necessário para passar a Estudos Maiores, o qual vai procurar na Europa" (ALCÂNTARA, 1832d, [s.p]). Aqui, o mapa mostra claramente que os alunos mais adiantados em Gramática Latina procuraram prosseguir seus estudos na Europa. Grande parte da literatura disponível sobre Alcântara afirma que boa parte da população livre e branca viajava para Coimbra a fim de concluir seus estudos, incluindo algumas personalidades alcantarenses como: Joaquim Franco de Sá (1807-1851), Alexandre José de Viveiros (1817-1864) e Barão de São Bento (1819-1860) (Viveiros, 1999). Nesse sentido, pode-se dizer que era uma prática comum das famílias alcantarenses enviar seus filhos para estudar na Europa. 
Ainda na Câmara Municipal, foram encontradas informações dos discípulos da aula de primeiras letras do professor público José de Caxias. Nesse mapa de frequência, constam a data da entrada e os nomes completos de 58 alunos, com informação de que as classes eram de leitura, aritmética e gramática. As observações que estão no mapa são referentes às faltas e ao aproveitamento das aulas (ALCÂNTARA, 1831a, [s.p]). De fato, é possível notar a presença de faltas para todos os alunos no mapa analisado, sem justificativa. Contudo, Veiga (2008, p. 06) afirma que:

Os motivos foram de toda ordem e de maneira combinada: pobreza da população, trabalho infantil, dispersão populacional e das escolas, inconstância na administração política, limitações pedagógicas, mas principalmente em razão da presença de uma dissonância entre a expectativa de civilizar e o imaginário de uma população concebida como grupo inferior, de "difícil educação".

Nessa perspectiva, a autora colabora quando sinaliza outros elementos que tenham contribuído para a infrequência dos alunos no município de Alcântara. Ainda no mesmo mapa, é importante notar "o Método de Lancaster não compreende o ensino de gramática" e, diz ainda que "para poder regular minha tarefa gradualmente, o divide em quatro classes: formando a primeira da primeira parte; por constar a gramática de quatro e a segunda da segunda (ALCÂNTARA, 1831a, [s.p]). A esse respeito do método utilizado nas escolas alcantarenses, Bastos (2005, p. 36) aborda que:

O aluno é integrado a uma classe, depois de averiguado seu conhecimento. A classe tem um ritmo determinado de estudo e um programa a desenvolver de leitura, escrita e aritmética. Por exemplo, a leitura, para os menores da primeira classe, consiste em aprender o alfabeto e traçar as letras sobre a areia; na segunda classe, os alunos são iniciados nas sílabas de duas letras, que escrevem sobre a ardósia; na terceira, fazem a combinação com três letras; na quarta, trabalham as palavras com várias sílabas; na quinta, começam a ler, somente na sexta classe leem corretamente.

Com relação ao método Lancaster, o Regulamento de Instrução Pública, da Lei de $\mathrm{n}^{\circ} 267$, de 17 de dezembro de 1849, diz que:

Art. $1^{a}$. Os Professores Públicos de primeiras Letras da Província servir-se-ão no ensino da Mocidade do Método individual, simultâneo, e lancastrino, segundo a frequência dos seus alunos mínima, media, e máxima marcadas nos artigos seguintes, e ficam isso fato divididos em três categorias. Art. $2^{\mathrm{a}}$. Os que tiverem de dez a trinta e nove alunos ensinarão pelo método individual [...]. Art. $3^{a}$. Os que tiverem de quarenta a setenta e nove alunos ensinarão pelo Método simultâneo [...]. Art. $4^{a}$. Os que tiverem de oitenta a cento e sessenta alunos ensinarão pelo Método Lancastrino [...]. Art. $5^{a}$. Os que tiverem menos de dez alunos não são considerados em exercício, mas com licença, 
e receberão quando lecionarem somente metade do ordenado marcado no Artigo $2^{\mathrm{a}}$ (Maranhão, 1849).

Segundo Faria Filho (2007, p. 141), o método denominado lancasteriano ou mútuo, atribuído ao educador inglês Joseph Lancaster, "tem como característica principal o fato de utilizar os próprios alunos como auxiliares do professor". Nesse sentido, o inspetor da Instrução Pública ficava com a responsabilidade de fiscalizar a aplicação do método, além de outras atribuições que serão mencionadas no decorrer do texto.

Na Freguesia de São João de Cortes, consta na Câmara Municipal de Alcântara somente um mapa de frequência com a relação nominal dos alunos de primeiras letras, tendo como titular desta cadeira o professor Carlos Felippe de Barros, com 12 alunos matriculados, com entradas entre junho e dezembro de 1831 (ALCÂNTARA, 1832b, [s.p]). O que se percebe nesse mapa é que o quantitativo de alunos do professor Carlos Felippe de Barros atingia o mínimo exigido segundo o Regulamento de Instrução Pública, conforme com a Lei de $n^{\circ} 267$, de 17 de dezembro de 1849, pois, caso não houvesse o número mínimo de 10 alunos matriculados, o professor não receberia seus vencimentos (MARANHÃO, 1849). Semelhante determinação é lembrada por Veiga (2008, p. 05) quando afirma que "como documento de comprovação de frequência à sua aula, os professores deveriam elaborar mapas de frequência trimestrais, comprovando tanto a existência de alunos como o cumprimento de seu próprio trabalho". Tal registro era necessário, bem como eram exigidos para o recebimento dos salários.

Agora, na Secretaria do Governo de Instrução Pública consta um mapa com a relação dos alunos que frequentavam a aula de Gramática Latina do professor Paulo Alves Lima, nos anos de 1832 a 1836. Esses alunos tinham idades entre 11 a 20 anos. No mês em que foi realizado esse mapeamento, constam 14 alunos matriculados, alguns discriminados da seguinte forma: "podem passar a Maiores Estudos", estão em "tradução suficientemente", "adiantados", ou "não se desenvolveram em tradução", outros são "principiantes em tradução". O professor Paulo expõe ainda a necessidade de "dar pretérito e nominativo". Consta na observação final do mapa que as faltas são constantes, algumas delas motivadas por doença (ALCÂNTARA, 1836b, [s.p]). Durante os anos de 1832 a 1836, foram matriculados vários alunos. Os 
que tinham maior assiduidade tiveram maior aproveitamento escolar; quem detinha boa tradução prosseguia os estudos na capital ou, até mesmo, na Europa.

Até o momento, os mapas apontaram somente a participação de alunos nas classes de primeiras letras. Entretanto, consta na Instrução Pública do Município de Alcântara um mapa com 20 alunas da classe de primeiras letras que, ao longo dos anos de 1833 a 1836, foram matriculadas e estiveram sob a responsabilidade da professora Ana Joaquina de Seixas Correa. Nesse mapa, o que chama atenção é o primeiro nome da aluna "Ingnacia". Algumas têm nomes compostos e, as demais, nomes e sobrenomes. No mapa, ainda consta que, em termos de aproveitamento, todas as alunas estão "bem"; em relação à frequência, "regular"; a conduta moral é considerada "boa". A turma era dividida entre as classes de "leitura, aritmética e gramática" (ALCÂNTARA, 1836a, [s.p]).

A intenção de apresentar esse mapa de frequência é dizer que, entre os anos de 1833 a 1836, já existia a preocupação das autoridades para com a instrução pública do sexo feminino. No que tange ao nome da aluna "Ingnacia", o mapa não informa se era uma aluna branca ou negra. Entretanto, Cruz (2008, p. 174) diz que:

Em apreciação da documentação sobre a instrução pública no Maranhão, identifica-se uma série de mapas de turmas das vilas onde havia aulas de Primeiras Letras. Nestes mapas, praticamente não se evidencia a cor da pele dos alunos, embora haja entre seus nomes muitos alunos registrados apenas pelo prenome. A ausência de sobrenomes é um indício de origem escrava destas crianças, pois [...] era comum ao escravo só possuir o primeiro nome, herdando do senhor algumas vezes o sobrenome no ato da alforria.

A pesquisa realizada nos mapas de frequência das alunas da classe de primeiras letras leva a compartilhar a opinião da autora citada. Mesmo não discriminando a cor e o status de livre ou escrava, as informações contendo apenas o prenome são fortes indícios de que houve, nessa aula, alunas negras.

Ainda, referindo-se à educação para o sexo feminino, consta na Secretaria do Governo de Instrução Pública mapas de matrícula das aulas de primeiras letras de 32 alunas que ingressaram na escola entre os anos de 1835 a 1841, sob a orientação da professora Ana Joaquina de Siexas Correa. Esse mapa diz que todas as alunas matriculadas estão "bem em aproveitamento", enquanto a frequência é apresentada como "regular". Em relação à conduta na aula, todas as alunas estão "bem". É possível observar que, na primeira classe, foram matriculadas 18 alunas, tanto em leitura 
quanto em aritmética; na segunda classe, foram matriculadas 26 alunas em leitura e aritmética. O que mais chama a atenção é que somente 2 alunas são referidas apenas pelo prenome: "Barbara" e "Libania". Dezoito são referidas com nomes compostos e 11 com nomes e sobrenomes, exatamente como foi possível observar no mapa anterior (ALCÂNTARA, 1841a, [s.p]).

São poucos os mapas de matrículas e mapa de frequência de alunas encontradas no APEM. O interessante de se observar é que as aulas de primeiras letras para o sexo feminino não aprecem no mesmo tempo em que apareceram para o sexo masculino. É que, historicamente, a instrução foi em grande parte destinada aos homens. Segundo Bastos (2005, p. 39):

O programa de ensino compreende, para os meninos, a leitura, a escrita e o cálculo; para as meninas, a costura. Cada matéria ensinada nas escolas mútuas repousa sob um programa preciso e detalhado, que se encontra nos guias e tratados elaborados pelos responsáveis influentes do método: Nyon, Bally, Sarazin, e outros. Cada programa é dividido em oito graus hierarquizados, que devem ser percorridos sucessivamente. Por exemplo, as oito classes de escrita e leitura são: ABC, palavras ou sílabas de duas letras, de três letras, de quatro letras, de cinco letras, lições de palavras de muitas sílabas, leitura da Bíblia, seleção dos alunos que melhor leem na $7^{\text {a }}$ classe. Em Aritmética, combinação de unidades, dezenas, centenas, etc.; soma; soma composta; subtração; subtração composta; multiplicação; multiplicação composta; divisão; divisão composta; redução; regra de três; prática.

É possível perceber que, a partir das leis provinciais e da literatura aqui utilizada, a educação ofertada para o sexo feminino foi definida segundo os papéis que homens e mulheres desenvolviam na sociedade. Sinaliza, a esse respeito, o Art. $2^{\circ}$ do Regulamento de 17 de julho, que, aos meninos, cabia o ensino de instrução primária: a leitura e escrita, quatro operações fundamentais de aritmética, números inteiros, decimais e quebrados, sistema métrico decimal, gramática portuguesa, catecismo e noções de história sagrada, enquanto o Art. $4^{\circ}$ estabelece que às meninas, além das matérias especificadas no art. $2^{\circ}$, seriam ensinados bordados e trabalhos de agulha (MARANHÃO, 1874). Mesmo que o Regulamento aqui esteja datado em 1874, os mapas mostram que já existia uma educação diferenciada entre homens e mulheres nas freguesias de Alcântara.

A Secretaria de Governo de Instrução Pública determinava um quantitativo mínimo de 10 alunos para o funcionamento das escolas de primeiras letras, como já 
abordado na Câmara Municipal, Aqui, na Instrução Pública, o mapa dos alunos que frequentaram a aula de primeiras letras em São João de Cortes tem somente 6 alunos matriculados, dos quais 2 não haviam se apresentado, logo, não existem informações sobre os conhecimentos que trazem, e 3 alunos sabem "cartilha" e um "carta [ilegível]". Em relação aos adiantamentos que têm tido, o professor José Custódio da Silva Rapozo informa que eles vêm se desenvolvendo na "escrita, carta de nomes, cursiva, repartir, diminuir, gramática e proporções" (ALCÂNTARA, 1837, [s.p]). O objetivo de apresentar esse mapa é evidenciar o quantitativo insuficiente de alunos para que o professor José pudesse dispor de seus vencimentos. De acordo com Veiga (2008, p. 07), "havia muita discrepância entre o número de alunos registrados pelos professores nos mapas e o verificado pelo visitador". Contudo, os professores precisava garantir seu emprego e salário.

Existem casos de professores públicos que, por não terem o quantitativo mínimo exigido por lei, eram transferidos para outras localidades da província, se desejassem continuar a trabalhar. Por vezes, eles matriculavam alunos negros para continuar recebendo seus vencimentos e permanecer no mesmo local. As investigações de Cruz (2008, p. 195) realizadas na documentação manuscrita da Secretaria de Governo do Estado do Maranhão, dizem que:

Os dados permitem inferir que as camadas negras em condições diferenciadas no contexto imperial (a exemplo de liberto(a)s, escravo(a)s, ingênuos, escuros ou miscigenados) acessaram saberes da instrução elementar em processos escolares formais, apesar dos obstáculos impostos a elas. As formas de acesso se caracterizavam por estratégias variadas que abrangiam a frequência em escolas particulares (pouco controladas pelo estado), matrícula em aulas de primeiras letras, cujos professores dependiam de quantidades elevadas de alunos para garantir valores salariais e mistificação da condição de escravo, fazendo-se passar por livre.

As práticas civilizatórias de escravos em processos educacionais na sociedade escravista do Maranhão no século XIX se caracterizavam pela ilegalidade, porque existia um veto à escolarização de escravos segundo as leis provinciais. Nesse sentido, Faria Filho (2007, p. 145) comenta que "em todas as escolas é, geralmente, proibida a frequência de crianças negras, mesmo livres, até pelo menos até o final da primeira metade do século". Contudo, o autor (2007, p. 145) prossegue argumentado que tal atrativa não impediu, "que estas tomem contato com as letras e, às vezes, 
sejam instruídas, sobretudo no interior de um modelo mais familiar ou comunitário de escolarização". A necessidade de o professor manter seus vencimentos acabava por admitir a entrada de escravos nas aulas de primeiras letras, em muitos casos, passando-os por livres.

Em relação ao acesso aos saberes da instrução elementar, no mapa de frequência da Instrução Pública, constam 60 alunos entre 6 e 9 anos de idade matriculados nas aulas de primeiras letras sob a orientação do professor púbico José Mariano Gomes Ruas. No referido mapa, consta que, dos 60 alunos matriculados, 54 "nada sabem", o que representa um quantitativo elevado de alunos (90\%) que não tiveram contato com a leitura e escrita antes de ingressar na escola, enquanto os outros 6 (10\%), que já "soletravam bem", haviam sido iniciados na leitura e escrita em espaços não institucionalizados (ALCÂNTARA, 1841c, [s.p]). Sobre uma educação formal e não formal, Faria Filho (2007, p. 145) contribui afirmando:

Não podemos considerar que apenas aqueles, ou aquelas, que frequentavam uma escola fora do ambiente doméstico tinham acesso às primeiras letras. Pelo contrário, temos indícios de que a rede de escolarização doméstica, ou seja, de ensino e aprendizagem da leitura, da escrita e do cálculo, mas sobretudo daquela primeira, atendia a um número de pessoas bem superior ao da rede pública estatal. Essas escolas, às vezes chamadas de particulares, outras vezes de domésticas, ao que tudo indica, superavam em número, até bem avançado o século XIX, naquelas cujos professores mantinham um vínculo direto com o Estado.

Este excerto permite afirmar que os primeiros contatos com a leitura, a escrita e os cálculos aconteciam em espaços domésticos, ou melhor, no âmbito do privado, porque, em relação ao adiantamento, alguns mapas informam que alguns alunos já traziam algum conhecimento.

Ainda se referindo aos conhecimentos que trazem nos mapas das turmas do professor Joaquim Valentim Maramalho, é informado que as aulas iniciaram com 13 alunos e que, no final do mês de dezembro, havia 20 alunos matriculados na freguesia de Santo Antonio e Almas. O que mais chama a atenção em todos os mapas é que, nas primeiras letras, aparecem as observações sobre os conhecimentos que trazem: "algum, nenhum, sílabas de 3 letras". Esses conhecimentos que trazem, especificamente nesse mapa, são fruto de práticas de leitura e escrita que aconteceram em ambientes não escolares. No que diz respeito à conduta moral, o mapa apresen- 
ta: "sofrível, agradável, ruim, regular, melhor e boa" (ALCÂNTARA, 1841b, [s.p]). No que concerne às faltas apresentadas, estas foram justificadas, em sua maioria, por motivo de moléstia.

No que tange à conduta moral, compartilha-se do entendimento de que a educação era um processo educacional e civilizatório. Diz Cruz (2008, p. 179): "na província do Maranhão, observa-se que os negros se apropriavam de símbolos de civilidade associados à cultura europeia, o que serve para desmistificar os discursos estereotipados que os caracterizavam como seres bárbaros".

Entretanto, os indícios sinalizam a presença de negros nas aulas de primeiras letras a partir de uma intensa investigação no APEM. Contudo, existem somente sinalizações que permitem pensar em uma educação para negros. Dessa forma, fica claro que "educar para civilizar" era um lema presente nos discursos das elites, tanto brasileira quanto maranhense, durante o século XIX.

\section{CONCLUSÃO}

A História da Educação, no que diz respeito à escolarização das "camadas inferiores da sociedade", especialmente a população negra, foi em grande parte silenciada pelas produções literárias, pois o que se tem sobre História da Educação consiste na história da escolarização das camadas médias brasileiras, ou seja, de um grupo racial branco que elaborava leis e regulamentos para proibir o acesso a grupos sociais ditos "inferiores" no processo educacional

Nesse artigo, fica evidente o silenciamento e, até mesmo, a omissão por parte da história oficial da educação brasileira sobre fatos e acontecimentos no que concerne à escolarização da população negra. Porém, essa tentativa denuncia que a população conseguiu driblar os múltiplos impedimentos à instrução pública elementar.

A literatura pesquisada sinaliza que o acesso dos escravos à leitura e escrita indica tal prática desde o século XVIII, ainda que não necessariamente realizada em uma escola. Contudo, é importante salientar que a população negra não ficou alheia ao processo de escolarização, visto que as práticas de leitura e escrita já se davam em um contexto no qual ocorria crescente valorização da alfabetização. Por fim, pode-se dizer que são raríssimos os documentos que tratam da instrução pública no 
município de Alcântara acondicionados no Arquivo Público do Maranhão - APEM.

\section{REFERÊNCIAS}

ALCÂNTARA, Câmara Municipal. Informação dos discípulos da aula de $1^{\text {as }}$ letras da vila de Alcântara: reg. 039, (map 04): Alcântara, 1831a.

ALCÂNTARA, Câmara Municipal. Lista dos alunos que frequentão a aula de Gramática Latina em Alcântara: reg. 005, (map 04): Alcântara, 1831b.

ALCÂNTARA, Câmara Municipal. Aula Nacional da Ilustríssima Câmara da Vila de Alcântara: regs. 031, (map 04): Alcântara, 1832a.

ALCÂNTARA, Câmara Municipal. Relação nominal dos alunos de $1^{\text {a }}$ letras da Cadeira de São João de Cortes: reg. 029, (map 04): Alcântara, 1832b.

ALCÂNTARA, Câmara Municipal. Mappa dos alunos da aula de primeiras Letras na Vila de Alcântara: reg. 062, (map 04): Alcântara, 1832c.

ALCÂNTARA, Câmara Municipal. Lista dos alunos que frequentão a aula de Gramática Latina em Alcântara: reg. 010, 012, 015, 020, 018 e 024 (map 04): Alcântara, 1832d.

ALCÂNTARA, Câmara Municipal. Mappa estatístico dos alunnos que frequentarão a aula de $1^{\text {as }}$ letras do lugar de São João de Cortes: reg.121, (map 04): Alcântara, 1837.

ALCÂNTARA, Câmara Municipal. Relação dos alunnos que frequentão escola particular de $1^{\text {as }}$ letras nesta cidade de Alcântara: reg. 036, (map 04): Alcântara, 1838.

ALCÂNTARA, Instrução Pública. Mappa informativo das alunas da Aula de $1^{\text {as }}$ letras do $4^{\circ}$ trimestre do corrente ano: reg. 029, (map 06): Alcântara; 1836a.

ALCÂNTARA, Instrução Pública. Listas dos alunnos que frequentão a aula de Gramática Latina em Alcântara: reg. 142 e 144, (map 06): Alcântara, 1836b.

ALCÂNTARA, Instrução Pública. Mappa informativo das alunas da Aula de $\mathbf{1}^{\text {as }}$ letras pertencente ao $2^{\circ}$ trimestre do conente ano: reg. 118, (map 06): Alcântara, 1841a.

ALCÂNTARA, Instrução Pública. Relação dos discípulos que frequentam a aula de $1^{\text {as }}$ letras da freguesia de Santo Antonio e Almas: regs. 094, 096, 105, 110, 112 , 
116, 117, 120 e 121 (map 06): Alcântara, 1841b.

ALCÂNTARA, Instrução Pública. Mapa estatístico dos alunos que frequentam a aula de $1^{\text {as }}$ letras da cidade de Alcântara: reg. 118, (map 06): Alcântara, 1841c.

BASTOS, M.H.C. O ensino monitorial/mútuo no Brasil (1827-1854). In: STEPHANOU, Maria \& BASTOS. M.H.C. Histórias e memórias da educação no Brasil (orgs). Vol. II. Petrópolis: Vozes, 2005.

BRASIL. Lei de 25 de março de 1824. Constituição Política do Império do Brasil, elaborada por um Conselho de Estado e outorgada pelo Imperador D. Pedro I. Disponível em:<http://www.planalto.gov.br/ccivil 03/constituicao/constituicao24.htm>. Acesso em: 30 jun. 2020.

CRUZ, Mariléia dos Santos. Escravos, forros e ingênuos em processos educacionais e civilizatórios na sociedade escravista do Maranhão no século XIX. Araraquara: UNESP, 2008, 195 f. Tese (Doutorado em Educação) - Programa de Pós-Graduação em Educação Escolar, Faculdade de Ciências e Letras, Universidade Estadual Paulista, Araraquara, 2008.

FARIA FILHO, Luciano de. Instrução elementar no século XIX. In: LOPES. Eliane Marta Teixeira; FILHO. Luciano de Farias \& VEIGA. Cynthia Greive (org) 500 anos de educação no Brasil. 3 ed. Belo Horizonte: Autentica, 2007.

GUIMARÃES CARVALHO, María Elizete. Independência e educação: recortes do processo educacional brasileiro nas primeiras décadas do império (18221836). Historia Caribe, vol. V, núm. 14, 2009. Disponível em: http://www.redalyc.org/ pdf/937/93717337007.pdf Acesso em: 02 set. 2020.

MARANHÃO. Regulamento da instrução pública - 1854. Do inspetor da instrução pública e seus delegados. Coleção de Leis, decretos e Resoluções da Província do Maranhão - 1854 a 1855, São Luís, Typografia Constitucional de I. e J. Ferreira, 1856.

MARANHÃO. 17 de dezembro de 1849. Livro de Leis e Resoluções da Assembleia Legislativa Provincial. Secretaria da Província. Registro: fl. 76 v. Setor Códices: Arquivo Público do Maranhão - APEM.

MARANHÃO. Regulamento 06 de julho de 1874. In: Coleção de leis, decretos e resoluções da Província do Maranhão. Maranhão: Tipografia Constitucional de I. J., Ferreira, 1856.

NUNES, Clarise; CARVALHO, Marta Maria Chagas de. Historiografia da educação e fontes. In: GONDRA. José Gonçalves (org). Pesquisa em história da educação no 
Brasil. Rio de Janeiro: DP\&A, 2005.

PESAVENTO, Sandra Jatahy. História \& história cultural. 2 ed. Belo Horizonte: Autêntica, 2005.

STEPHANOU, Maria; BASTOS, Maria Helena Camara (orgs). Histórias e memórias da educação no Brasil, vol III: século XX. 4 ed. Petrópolis, Rio de Janeiro: Vozes, 2011.

VEIGA, Cynthia Greive. Escola pública para os negros e os pobres no Brasil: uma invenção imperial. Revista Brasileira de Educação v. 13 n. 39 set./dez. 2008. 


\section{UMA ANÁLISE CRITICA DO PENSAMENTO DE MICHEL FOUCAULT SOBRE A PRISÃO: FORMAS DE VIGIAR E PUNIR NO ATUAL SISTEMA PRISIONAL BRASILEIRO EM CRISE}

Taine Pires Duarte 6 


\section{INTRODUÇÃo}

Esta pesquisa tem por princípio perseguir uma das temáticas mais polêmicas na atualidade, consiste em problematizar a crise do sistema prisional brasileiro, a partir da utilização das ideias de Michel Foucault (2016) sobre a evolução do sistema penal. Partindo da atual conjuntura brasileira quanto à capacidade da prisão em reeducar os indivíduos é que trazemos a perspectiva de Michel Foucault, que volta ao século XVIII, para entender como se configurou o sistema prisional dos nossos dias. Para além de um diagnóstico claro e preciso, trata-se de aplicar essa contribuição teórica para compreender a realidade brasileira e propor novos caminhos para a reformulação do sistema prisional no Brasil.

A ênfase da pesquisa se estabelece na historicidade das formas de punição ao longo do tempo, tendo a obra "Vigiar e Punir - nascimento da prisão" o ponto de partida para construir interpretações acerca da realidade das formas de se vigiar e punir empregadas no castigo e recuperação da delinquência. As análises de Michel Foucault neste livro específico é um esforço intelectual original e imprescindível no entendimento da criminalidade em conflito com a sociedade que pune os sujeitos que transgridem a ordem estabelecida.

Os objetivos a serem alcançados estão em entender como a prisão se configurou no tempo a partir de práticas punitivas marcadas pela agressão e morte dolorosa até os mecanismos atuais mais brandos e "humanizadores". A metodologia aplicada está por meio da leitura da obra em questão e as contribuições teóricas apresentadas, os dilemas enfrentados e fragilidades do sistema ligando com as conclusões de Foucault sobre a impossibilidade da prisão em reeducar sujeitos.

O poder sempre construiu seus artifícios no combate ao crime, na preservação da ordem pública mediante princípios que vão desde a tortura física, nos castigos corporais, até as formas mais modernas de punição, onde a prisão é sua maior representante, que nas conclusões de Michel Foucault se encontra em crise e não promove a "regeneração" de sujeitos à margem da sociedade, conforme pretendia em seu formato original.

Sempre atentos à questão das relações de poder que se configuram como chave de leitura, entende-se que cada sociedade construiu seus mecanismos punitivos,

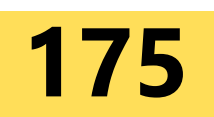


suas maneiras de sujeição dos indivíduos que ameaçavam os interesses da elite. Para subsidiar os poderes estabelecidos emergem-se os saberes (como a medicina e a psiquiatria) que promovem determinados conhecimentos que excluem os indivíduos, criam conceitos, estabelecem "verdades", separam, constroem discursos de poder.

Foucault realiza um estudo do processo de evolução das práticas punitivas, tendo como epicentro a sociedade francesa do século XVIII. Sempre atento à tríade poder, saber e verdade pretende-se percorrer o caminho trilhado contextualizado as formas de exercício do poder e da justiça, começando pelo suplício (primeira parte), passando pela punição (segunda parte), com a chegada da disciplina (terceira parte), é enfim com o surgimento do modelo de cerceamento da liberdade atual que é a prisão (quarta parte). Percorreremos o caminho dessa evolução no entendimento da prática da pena, focando na prisão como sendo o auge das formas punitivas pelo poder e interesse maior da pesquisa.

Produzindo uma discussão crítica atual sobre a prisão e transferindo para a sociedade brasileira, na impossibilidade desse modelo de agir de forma "humanizadora" sobre os condenados. Entende-se que um dos alvos principais da punição recaiu sobre o corpo, sob a forma de tortura, que era uma maneira de exemplo social que deveria ser evitado, pois os castigos eram aplicados de forma dolorosa. Com o tempo os aparatos disciplinares tomaram um rumo diferente, onde o pena não foi dirigido essencialmente para o corpo, mas sim para a "alma", ou seja, para o psicológico dos indivíduos.

Essa mudança na "economia de poder" garantiu uma maior humanidade para as penas, fazendo com que ampliassem o significado da pena para além do castigo físico, atingindo o psicológico dos condenados. Isso não quer dizer que as antigas práticas de tortura foram banidas, mas resistiram no tempo, se fazendo presente em situações de aplicação de uma pena. Com a prisão emergem-se uma nova postura no trato com a penalidade, acreditando-se que a mesma seria capaz de reeducar o sujeito, mas o que Foucault elabora como conclusão é que esse sistema gerou suas falhas, é que são facilmente notadas atualmente.

Então o autor quer fazer um estudo crítico de como a prisão se tornou um aparato de poder deficiente e que se estabelece como um problema nocivo para a socie- 
dade contemporânea que não consegue ver na prisão um espaço de reeducação dos condenados, mas como um "depósito" de delinquentes que ameaçam a sociedade.

Partimos do século XVIII onde o pensamento de Foucault abriu o seu caminho interpretativo sobre a punição até a chegada da prisão e sua crise quando tratada na ótica brasileira. Uma análise que pode ser aplicada ao pensar o que a sociedade pune e vigia seus detratores.

\section{DESENVOLVIMENTO}

O objetivo dessa investigação está em mapear com exatidão a passagem da forma punitiva baseada no suplício para a adoção de práticas mais humanas em se tratando de retirar do corpo a força e poder para a condição psicológica como ato de sujeição do crime cometido.

O suplício pode ser entendido por uma prática de punição extremamente dolorosa em que o condenado sofre as mais terríveis atrocidades, comuns no período absolutista francês do século XVIII, onde a aplicação da justiça era exercida para coibir possíveis crimes e como exemplo social, como o caso de:

[Damiens fora condenado, a 2 de março de 1757], a pedir perdão publicamente diante da porta principal da Igreja de Paris [aonde devia ser] levado e acompanhado numa carroça, nu, de camisola, carregando uma tocha de cera acesa de duas libras; [em seguida], na dita carroça, na Praça de Greve, e sobre um patíbulo que aí será erguido, atenazado nos mamilos, braços, coxas e barrigas das pernas, sua mão direita segurando a faca com que cometeu o dito parricídio, queimada com fogo de enxofre, e às partes em que será atenazado se aplicarão chumbo derretido, óleo fervente, piche em fogo, cera e enxofre derretidos conjuntamente, e a seguir seu corpo será puxado e desmembrado por quatro cavalos e seus membros e corpo consumidos ao fogo, reduzidos a cinzas, e suas cinzas lançadas ao vento (FOUCAULT, 2014, p. 9).

O próximo passo seria o seu esquartejamento, em praça pública, com os mais severos requintes de crueldade, onde o corpo era o alvo principal. Assim sendo, "em cumprimento da sentença, tudo foi reduzido a cinzas. O último pedaço encontrado nas brasas só acabou de se consumir às dez da noite" (FOUCAULT, 2014, p. 11).

O autor aponta que uma série de reformas foram sendo praticadas, uma nova justiça penal, e entre as mudanças substanciais está o "o desaparecimento dos suplícios. Hoje existe a tendência a desconsiderá-lo; talvez, em seu tempo, tal desaparecimento tenha sido visto com muita superficialidade ou com exagerada ênfase como 
"humanização" que autorizava a não analisá-lo" (FOUCAULT, 2014, p. 13).

A noção de conduzir o condenado pelas ruas, em um espaço destinado para tais fins deu a essa tipologia de crime certo grau de espetáculo, tudo era realizado para o cumprimento de determinados rituais e encenações. Por isso, formas mais sutis foram sendo elaboradas, a tentativa de se eliminar a tortura física, empreendendo medidas de privação da liberdade foram ganhando destaque.

Assim, a partir da segunda metade do século XVIII, surgiu o poder disciplinar, o qual controlou a sociedade burguesa nascente. Surgiram também as disciplinas que garantiram a articulação harmoniosa da sociedade. Desse modo, a disciplina passou a controlar os indivíduos estabelecendo relações de poder reguladas pelas normas. A disciplina executou a distribuição dos indivíduos no espaço. Para isso, utilizou-se de técnicas como, por exemplo, o grande encarceramento dos considerados vagabundos e dos miseráveis. No entanto, o corpo só terá utilidade se for produtivo e submisso. Essa sujeição é obtida através de um saber e de um controle que constituem o que Foucault chamou de uma tecnologia política do corpo, que para ele, trata-se de uma microfísica do poder (SOUSA; MENESES, 2010, p. 25).

Na passagem do século XVIII para o XIX a sociedade se defronta com novas necessidades de aplicação de uma pena. Buscou-se atingir a pena por mecanismos de força mais tênues e significativamente com um maior alcance de tempo e diminuição na intensidade. Agora "o corpo é colocado num sistema de coação e de privação, de obrigações e de interdições. O sofrimento físico, a dor do corpo não são mais elementos constitutivos da pena. O castigo passou de uma arte de sensações insuportáveis a uma economia de direitos suspensos" (FOUCAULT, 2014, p. 16).

É certo dizer que mesmo com uma diminuição da ênfase do suplício sobre o corpo, ainda persistiram formas de punição que recaiam sobre o mesmo, como "redução alimentar, privação sexual, expiação física, masmorra" (FOUCAULT, 2014, p. 20-21).

Foucault defende que mesmo os modernos mecanismos de justiça criminal trazem consigo a intenção de subjugação do corpo em suas práticas. Ou seja, conviveram medidas de punição com as formas ultrapassadas de suplício. A intensidade do sofrimento é realizada através da pressão psicológica sobre o infrator no qual ele é conduzido a refletir sobre os seus atos. Substitui-se a morte pela perda da liberdade, não deixando de lado a coerção física do corpo, como foco da pena.

O afrouxamento da severidade penal no decorrer dos últimos séculos é um fenômeno bem conhecido dos historiadores do direito. Entretanto, foi visto,

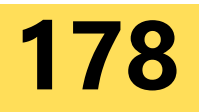


durante muito tempo, de forma geral, como se fosse fenômeno quantitativo: menos sofrimento, mais suavidade, mais respeito e "humanidade". Na verdade, tais modificações se fazem concomitantes ao deslocamento do objeto da ação punitiva. Redução de intensidade? Talvez. Mudança de objetivo, certamente. Se não é mais ao corpo que se dirige a punição, em suas formas mais duras, sobre o que, então, se exerce? A resposta dos teóricos — daqueles que abriram, por volta de 1780 , o período que ainda não se encerrou - é simples, quase evidente. Dir-se-ia inscrita na própria indagação. Pois não é mais o corpo, é a alma. À expiação que tripudia sobre o corpo deve suceder um castigo que atue, profundamente, sobre o coração, o intelecto, a vontade, as disposições (FOUCAULT, 2014, p. 21).

Concomitantemente à adoção de um novo regime de poder sobre o corpo, também emergem um conjunto de saberes que alicerçam tais práticas, chamadas por ele de "discursos" que fundamentam a prática de punição. Foucault (2014, p. 26-27) delimita o objetivo de seu livro que pretende "uma história correlativa da alma moderna e de um novo poder de julgar; uma genealogia do atual complexo científico-judiciário onde o poder de punir se apoia, recebe suas justificações e suas regras, estende seus efeitos e mascara sua exorbitante singularidade".

Com a evolução das técnicas de punição, um elemento ainda permanece como norteador das penalidades, que é por fim, o corpo. Este sendo agora pensado como maleável diante de um sistema que suaviza a dor e minimiza a violência. $O$ corpo agora passa a ser investigado e estudado dentro de uma nova "economia de poder", atravessado por questões políticas, passando pela sua utilidade. Percebeu-se que uma melhor postura sobre sua sujeição seria integrá-lo na sociedade, como foco de submissão ou mesmo como objeto de produção.

Agora, o que Foucault (2014, p. 34) quis dizer é que o corpo está inserido em uma nova forma de se aplicar o poder na sociedade, conferindo a ele a mesma severidade, mas através de instâncias que irradiam na sociedade, seja através de aparelhos ou instituições destinadas a esses objetivos, sendo que passa do castigo físico para o "castigo da alma" do condenado. Agindo diretamente na sua subjetividade, uma forma de violência simbólica e emocional. Tendo a prisão como auge dos "investimentos políticos sobre do corpo".

Com o lluminismo ocorre um lento processo de transição que traz à tona uma relação mais humanizada ao se tratar das penas:

O protesto contra os suplícios é encontrado em toda parte na segunda metade do século XVIII: entre os filósofos e teóricos do direito; entre juristas, 
magistrados, parlamentares; nos chaiers de doléances e entre os legisladores das assembléias. É preciso punir de outro modo: eliminar essa confrontação física entre soberano e condenado; esse conflito frontal entre a vingança do príncipe e a cólera contida do povo, por intermédio do supliciado e do carrasco. O suplício se tornou-se rapidamente intolerável. Revoltante, visto da perspectiva do povo, onde ele revela a tirania, o excesso, a sede de vingança e o "cruel prazer de punir" (FOUCAULT, 2014, p. 73).

Convergem-se uma série de críticas às formas severas de punição. Abrem-se a possibilidade de rever como se exerce o poder. A partir daí a punição é vista de forma mais generalizada e ampla. Ocorre uma universalização do poder de punição, não apenas a vontade do soberano e sua força de poder, mas ampliar essa visão para toda a sociedade, ou seja, descentralizar os mecanismos de poder. Criam-se as medidas no ato de punir, tratando-se de abandonar as táticas até então utilizadas, também tende-se a classificar os crimes e caracterizar os condenados, nessa nova "tecnopolítica de punição" (FOUCAULT, 2014, p. 91).

A mitigação da pena se processa no tempo de duração, agora em um tempo mais longo, ao contrário do suplício que se dá em um tempo mais curto, conforme a natureza da pena. O grande fator de ação do castigo se configura na duração do mesmo. Dessa forma "no antigo sistema, o corpo dos condenados se tornava coisa do rei, sobre o qual o soberano imprimia sua marca e deixava cair os efeitos de seu poder. Agora, ele será antes um bem social, objeto de uma apropriação coletiva e útil" (FOUCAULT, 2014, p. 107).

A pena do condenado passa a ser vista como de interesse coletivo, pois o condenado presta serviço à sociedade, e a mesma observa os resultados de sua ação, contrário ao suplício que vê nos atos de punição o sentimento de medo e pavor social. Sendo agora que o foco se dá no exemplo, na lição e na moral pública.

Nesse momento a prisão já é idealizada para certos tipos de crimes, é até mesmo muito criticada por muitos reformadores, vista como nociva, e até mesmo inútil, pois acentuam-se os problemas, é e vista como um aparelho de tirania. Na sua configuração inicial:

A prisão se pareceria demais com uma fábrica deixando-se os detentos trabaIhar em comum. As razões positivas em seguida: o isolamento constitui "um choque terrível", a partir do qual o condenado, escapando às más influências, pode fazer meia-volta e redescobrir no fundo de sua consciência a voz do bem; o trabalho solitário se tornará então tanto um exercício de conversão quanto de aprendizado; não reformará simplesmente o jogo de interesses 
próprios ao homoeconomicus, mas também os imperativos do indivíduo moral (FOUCAULT, 2014, p. 121).

As práticas de punição tem na prisão a institucionalização máxima do poder, sendo assim lentamente ultrapassadas as punições pela via da violência física, onde o corpo passa a ser regido por normas e condutas investidas de autoridade e saber. Isso significa dizer que o indivíduo passa a ser regido por uma ampla rede de poderes que juntos se entrelaçam, se confundem, e potencializam o efeito disciplinarizador capaz de reger indivíduos uteis e dóceis perante a sociedade. A evolução das práticas punitivas não deixa de ser um ato de exercer poder, de controlar as pessoas, de manter a ordem social a partir do ponto de vista de que o detento deve ser corrigido, adaptado e regenerado pelo meio social a fim de impor a ele a civilização e seu aparato jurídico e não nega-lá ao contrário no que ocorre nas formas de punição via tortura-corpo.

\section{RESULTADOS E DISCUSSÃO}

O corpo assim é visto como objeto de controle, de docilidade e utilidade constante. A disciplina e capaz de adaptar o corpo dos indivíduos a seu modo. O corpo se circunscreve dentro de um sistema que regula e delimita sua atuação. Essa forma de dominação passa a ser aplicada em vários setores da sociedade, como em colégios, hospitais, e nas organizações militares. Está nova forma de encarar a disciplina acabará por enraizar em todas as formas de vigilância da sociedade. Seja na:

"minúcia dos regulamentos, o olhar esmiuçante das inspeções, o controle das mínimas parcelas da vida e do corpo darão em breve, no quadro da escola, do quartel, do hospital ou da oficina, um conteúdo laicizado, uma racionalidade econômica ou técnica a esse cálculo místico do ínfimo e do infinito" (FOUCAULT, 2014, p. 138).

O poder disciplinar se torna o centro do dispositivo de adestramento dos indivíduos na sociedade, está em toda parte, age de forma indiscreta, está infiltrado em todas as instituições que pressupõe manter a ordem e as relações de poder, age de forma a atenuar os conflitos, perceber os problemas e corrigir a contento.

Uma das características adotadas pelos regimes disciplinares das instituições está na criação da ideia de "clausura", organizando o espaço e delimitando cada indivíduo em seu lugar específico. As instituições disciplinares vão aos poucos orga- 
nizando o espaço tendo em vista a criação de lugares que facilitem a vigilância e a instituição de espaços úteis para o trabalho. É uma caraterística fundamental que é paralelo a esse processo, está no caráter terapêutico que as instituições vão adotando, caracterizando os indivíduos em suas doenças, está aí a utilização do ponto de vista médico, classificando sujeitos e discursos de saber e poder.

Na concepção foucaultiana, os dispositivos do poder disciplinar caracterizam-se pela minúcia e pelo detalhe. Nesse sentido, o corpo será submetido a uma forma de poder que irá desarticulá-lo e corrigi-lo através de uma nova mecânica do poder. As práticas disciplinares permitem o controle das operações dos corpos e a sujeição constante de suas forças, impondo-lhes uma relação de docilidade e utilidade (SOUSA; MENESES, 2010, p.26).

O poder da disciplina delimita o espaço de atuação de sujeitos, "organizando as "celas", os "lugares" e as "fileiras" criam espaços complexos, ao mesmo tempo arquiteturais, funcionais e hierárquicos" (FOUCAULT, 2014, p. 145). Percebe-se que a criação destes espaços têm uma dupla finalidade, e ao mesmo tempo em que promove a perda da liberdade estabelece a produção de riquezas. Tem a capacidade de adestramento, capaz de moldar os indivíduos de acordo com o seu interesse:

O primeiro dispositivo usado pela sociedade, segundo Foucault, é a vigilância. Para haver vigilância, há custos econômicos e políticos. Econômicos porque precisam de investimentos com materiais e pessoas que possa agir como vigilantes. Custos políticos porque se a violência existir, por causa da vigilância, podem ocorrer revoltas. Isso é um custo político porque "desgasta" a imagem daqueles que estruturam essas forças e mantém tais mecanismos. Foucault também descreve o forte poder vigilante existente nas prisões, nas clínicas de recuperação, nos hospitais, enfim, nas formas de construção e estruturação dos locais onde se tratam do ser humano. No entanto, para uma maior precisão sobre a eficácia da vigilância, cria-se a filosofia do controle pelo olhar. Nasce a figura do inspetor (BRÍGIDO, 2013, p. 62-63).

A introdução da vigilância através do "olhar" se torna uma das grandes chaves de entendimento do poder disciplinar, onde "o exercício da disciplina supõe um dispositivo que obrigue pelo jogo do olhar, um aparelho onde as técnicas que permitem ver induzam a efeitos de poder, e onde, em troca, os meios de coerção tornem claramente visíveis aqueles sobre quem se aplicam" (FOUCAULT, 2014, p. 168). Ele se faz presente nas aparências:

O que permite ao poder disciplinar ser absolutamente indiscreto, pois está em toda parte e sempre alerta, pois em princípio não deixa nenhuma parte às escuras e controla continuamente os mesmos que estão encarregados de controlar; e absolutamente "discreto", pois funciona permanentemente e em 
grande parte em silêncio. A disciplina faz "funcionar" um poder relacionai que se auto-sustenta por seus próprios mecanismos e substitui o brilho das manifestações pelo jogo ininterrupto dos olhares calculados. Graças às técnicas de vigilância, a "física" do poder, o domínio sobre o corpo se efetuam segundo as leis da ótica e de mecânica, segundo um jogo de espaços, de linhas, de telas, de feixes, de graus, e sem recurso, pelo menos em princípio, ao excesso, à força, à violência. Poder que é em aparência ainda menos "corporal" por ser mais sabiamente "físico" (FOUCAULT, 2014, p. 174).

Aqui está uma das grandes interpretações acerca do poder em nossa sociedade, seja em qualquer instituição e espaço em que ele atue, e é uma das grandes contribuições de Michel Foucault sobre o exercício do poder em nossa sociedade. Uma atenção especial em relação aos atos humanos, ao seu comportamento, diferenciando os indivíduos, é fundamental para o funcionamento pleno das instituições. Mais precisamente o indivíduo passa a ser "fabricado" se torna um produto das relações de poder dispostas na sociedade.

A disciplina é capaz de classificar os sujeitos sociais, como por exemplo, mendigos, leprosos, vagabundos, loucos e violentos são colocados em um espaço de vigilância à margem da sociedade, vistos a partir dos instrumentos de poder como perigosos à ordem desde o início do século XIX. Assim criam-se:

O asilo psiquiátrico, a penitenciária, a casa de correção, o estabelecimento de educação vigiada, e por um lado os hospitais, de um modo geral todas as instâncias de controle individual funcional num duplo modo: o da divisão binária e da marcação (louco não louco; perigoso-inofensivo; normal-anormal); e o da determinação coercitiva, da repartição diferencial (quem é ele; onde deve estar; como caracterizá-lo, como reconhecê-lo; como exercer sobre ele, de maneira individual, uma vigilância constante, etc) [...] Todos os mecanismos de poder que, ainda em nossos dias, são dispostos em torno do anormal, para marcá-lo como para modificá-lo, compõem essas duas formas de que longinquamente derivam (FOUCAULT, 2014, p. 193-194).

Nesse sentido o Panóptico é um modelo clássico de Jeremy Benthan (17481832) que idealizou um modelo estrutural capaz de servir de exemplo para escolas, prisões, hospícios e hospitais, residindo em sua capacidade de realizar uma ampla vigilância e utilidade dos indivíduos. A observação era o elemento definidor desse sistema, que o encarcerado não poderia ver nada do exterior, nem mesmo o vigilante que está na torre do edifício. Sendo um jurista, construiu uma forma de pensar que por meio desse sistema, o indivíduo nele passaria pelas mais terríveis provas psicológicas, é essa sensação de solidão causada pelo panóptico, faria do mesmo um 
sujeito mais propenso a não praticar seus erros. Na sua visão esse modelo seria um regenerador das pessoas e marcaria uma presença do Estado na sociedade prevenindo os crimes, intimidando as pessoas a não adotarem práticas criminosas. Então "o Panóptico é uma máquina maravilhosa que a partir dos desejos mais diversos, fabrica efeitos homogêneos de poder" (FOUCAULT, 2014, p. 196). As formas de poder disciplinares:

\begin{abstract}
Pode-se então falar, em suma, da formação de uma sociedade disciplinar nesse movimento que vai das disciplinas fechadas, espécie de "quarentena" social, até o mecanismo indefinidamente generalizável do "panoptismo". Não que a modalidade disciplinar do poder tenha substituído todas as outras; mas porque ela se infiltrou no meio das outras, desqualifícando-as às vezes, mas servindo-lhes de intermediária, ligando-as entre si, prolongando-as, e principalmente permitindo conduzir os efeitos de poder até os elementos mais tênues e mais longínquos. Ela assegura uma distribuição infinitesimal das relações de poder (FOUCAULT, 2014, p. 209).
\end{abstract}

A entrada da disciplina nas instituições sociais marcadas pelas relações de poder, vão aos poucos conduzindo na emergência da prisão para a punição dos condenados. Michel Foucault traz a seguinte problemática: "devemos ainda nos admirar que a prisão se pareça com as fábricas, com as escolas, com os quartéis, com os hospitais, e todos se pareçam com as prisões?" (FOUCAULT, 2014, p. 219).

A forma de prisão se consolida como um espaço de detenção no princípio do século XIX. Por meio dela se consolidam tentativas humanizadoras de aplicação das penas. Constitui-se como um aparelho de dominação das sociedades civilizadas. Esse processo é consequência acima de tudo de uma melhoria no que tangência ao avanço das ideias e também aperfeiçoamento dos costumes. Então que "conhecem-se todos os inconvenientes da prisão, e sabe-se que é perigosa quando não inútil. E entretanto não "vemos" o que pôr em seu lugar. Ela é a detestável solução, de que não se pode abrir mão" (FOUCAULT, 2014, p. 224).

Inicialmente a prisão foi formulada como um sistema de transformar a vida dos indivíduos, segundo a sua utilidade e os conduzindo a passividade. A solidão do condenado tem a função de reflexão, de autoconsciência do crime praticado. $E$ assim o mesmo irá perceber os poderes que estão investidos sobre ele. Portanto "a prisão deve ser um microcosmo de uma sociedade perfeita onde os indivíduos estão isolados em sua existência moral" (FOUCAULT, 2014, p. 224). 
Michel Foucault se torna um crítico da prisão, pois mesmo nos dias atuais não opera no sentido de transformar a vida dos indivíduos na forma em que foi concebida inicialmente, mas ao contrário, é considerada um depósito de delinquentes e se torna para a atualidade um problema social sério. Por isso, analisando de perto as contribuições de Foucault, percebemos que o mesmo realiza um diagnóstico de como a prisão surgiu em nossa sociedade, o seu modelo de ação perfeita na vida das pessoas, é uma crítica ao que ela se tornou atualmente. Em Microfísica do Poder Michel Foucault é mais incisivo em dizer que:

[...] a prisão esteve, desde sua origem, ligada a um projeto de transformação dos indivíduos. Habitualmente se acredita que a prisão era uma espécie de depósito de criminosos, depósito cujos inconvenientes se teriam constatado por seu funcionamento, de tal forma que se teria dito ser necessário reformar as prisões, fazer delas um instrumento de transformação dos indivíduos. Isto não é verdade: os textos, os programas, as declarações de intenção estão aí para mostrar. Desde o começo a prisão devia ser um instrumento tão aperfeiçoado quando a escola, a caserna ou o hospital, e agir com precisão sobre os indivíduos. $O$ fracasso foi imediato e registrado quase ao mesmo tempo que o próprio projeto. Desde 1820 se constata que a prisão, longe de transformar os criminosos em gente honesta, serve apenas para fabricar novos criminosos ou para afundá-los ainda mais na criminalidade. Foi então que houve, como sempre nos mecanismos de poder, uma utilização estratégica daquilo que era um inconveniente (FOUCAULT, 1979, p.75).

A hipótese do esforço intelectual de Michel Foucault se concretiza na inviabilidade da prisão em conseguir realizar sua missão. Ela se faz contraditória em aplicar a pena, em transformar o indivíduo. Claramente se observa que ao fazer o percurso da pena desde o século XVIII até o XIX implicou em contribuir na tese de que a sociedade criou mais problemas é que a prisão é uma delas. Ela é afinal geradora de criminalidade, pois não consegue a partir do ponto de vista interno "revitalizar" o sujeito, mas o impele cada vez mais ao erro. À frente deteremos com mais precisão nas diversas questões que afetam o sistema prisional e sua incompatibilidade com o presente.

Aplicando a discussão proposta na realidade concreta brasileira almeja-se perceber as implicações da prisão na sociedade contemporânea no que tange à sua funcionalidade interna e as medidas de correção do sistema. Partindo dos últimos acontecimentos noticiados a partir da crise do sistema prisional brasileiro que está o interesse em entender essa conjuntura que se estabelece no Brasil. Para esclarecer a atualidade deste artigo cita-se alguns exemplos, como o caso da morte de 56 
presos na Rebelião do Complexo Penitenciário Anísio Jobim (COMPAJ) em Manaus, onde os agentes carcerários foram presos depois de negociações com os líderes da rebelião e autoridades. O motivo central para os acontecimentos esteve na disputa de facções rivais.

Outro caso ocorreu em Roraima na Penitenciária Agrícola de Monte Cristo (PAMC), onde 33 presos foram mortos que ocorreu um dia após a rebelião em Manaus e depois do anúncio de medidas do Governo Federal em relação à modernização do sistema penitenciário. No Rio Grande do Norte também foi alvo de outra rebelião que culminou na morte de 26 presos na Penitenciária Estadual de Alcaçuz. No Paraná, ocorreu outro fato na Penitenciária de Piraquara, onde 2 presos morreram e 28 fugiram. Em Minas Gerais, no Presídio Antônio Dutra Ladeira, os presos realizam um motim onde reivindicavam inúmeras melhorias, desde tratamento médico até abuso de parentes.

Em Santa Catarina, no Presídio Regional de Lages ocorreu um motim onde os presos colocaram fogo nos colchões e em São Paulo no Instituto Penal Agrícola na fuga de 200 presos. Todos esses fatos ocorreram no início deste ano, e são preocupantes, pois a maioria deles foi incentivada a partir de experiências semelhantes, havendo uma reação no presidio. Esses acontecimentos demostram a intensa fragilidade do nosso modelo carcerário que não promove em sua integralidade a verdadeira ação de reeducar os sujeitos para a sociedade, sendo depósitos de delinquentes.

Diante desse quadro propomos conduzir o debate sobre a seguinte problemática: "como ultrapassar a crise do sistema prisional brasileiro?" um motivo de reflexão atual e que o Brasil precisa reverter. A sociedade junto com os seus governantes precisa repensar o modelo prisional brasileiro a fim de conter crises como essa que afetam a população brasileira que se sente preocupada com o desenrolar e desfechos trágicos envolvendo os presídios do país.

Esses casos esclarecem o nível de calamidade que vivem as prisões pelo país. A crise do sistema pode ser analisada do ponto de vista macro sistêmico. O número de agentes penitenciários são inferiores ao que seria próximo do ideal. Somada a negligência de ações governamentais que possibilitem uma melhoria estrutural que é fundamental para a execução das penas. Tudo começa na valorização dos profissionais envolvidos. Mas o que ocorre é que: 
Os servidores públicos, independentemente da hierarquia funcional, são mal remunerados; não há equipamentos adequados às necessidades do trabalho; não há verbas para pesquisa; não há programas e muito menos apoio para introduzir estagiários que estejam cursando Direito, Medicina, Sociologia, Administração e outras disciplinas relacionadas com as questões do sistema. Esse quadro de carências e de anomia é muito bem ilustrado pelo médico Drauzio Varella, em seu depoimento sobre a vida prisional: "Dificuldades não faltavam. A medicação prescrita percorria complicadas vias burocráticas, e, nas frequentes transferências dos detentos de um pavilhão para outro, perdia-se no caminho. A burocracia era tanta que as internações e altas da enfermaria eram batidas em seis cópias, trazidas para assinar sem papel-carbono. Muitas vezes, como é característico no serviço público, existia fartura de antibióticos e antivirais caríssimos, enquanto faltava aspirina e remédio para sarna". (DOTTI, 2003, p.3-4).

As teorias de Michel Foucault são perfeitamente validadas quando olhamos a realidade de uma prisão. Um dos problemas é a falta de investimento no quadro de servidores das prisões que é um empecilho grave para sua manutenção, tanto no que consiste ao material disponibilizado para ao trabalho, quando na autoridade moral de lidar com os presos. Como prevê na Constituição de 1988 na separação dos detentos pela natureza dos delitos que não é praticada nas prisões do Brasil.

Art. $5^{\circ}$ Todos são iguais perante a lei, sem distinção de qualquer natureza, garantindo-se aos brasileiros e aos estrangeiros residentes no País a inviolabilidade do direito à vida, à liberdade, à igualdade, à segurança e à propriedade, nos termos seguintes: (...)

XLVIII - a pena será cumprida em estabelecimentos distintos, de acordo com a natureza do delito, a idade e o sexo do apenado (BRASIL, 2016, p. 9).

No que consiste na tarefa da prisão em promover a reeducação e ressocialização dos detentos o que sê vê é que a mesma não gera cidadãos conscientes de sua ação no mundo e capazes de repensar a sua própria individualidade e cidadania. Nesse sentido está à crítica de Michel Foucault sobre o sistema prisional como um todo. Nascida com a missão de "regenerar" os indivíduos e torna-los sujeitos capazes de agirem de forma benéfica para a sociedade o que a instituição faz e aumentar as estatísticas, potencializa a criminalidade e não cumpre o seu papel. Por isso:

As prisões não diminuem a taxa de criminalidade: pode-se aumentá-las, multiplicá-las ou transformá-las, a quantidade de crimes e de criminosos permanece estável, ou, ainda pior, aumenta [...] A prisão, consequentemente, em vez de devolver à liberdade indivíduos corrigidos, espalha na população delinquentes perigosos (FOUCAULT, 2014, p. 292-293). 
Outra negativa realidade são as doenças que acometem o ambiente das prisões, tendo como origem "o uso de drogas, a falta de higiene e toda a lugubridade da prisão fazem com que o preso que ali adentrou numa condição sadia de lá não saia sem ser acometido de uma doença ou com sua resistência física e saúde fragilizadas" (ASSIS, 2007, p. 75). Não existe um tratamento intenso, e muito menos a prevenção através de exames de rotina. Os requisitos básicos para a execução da pena são resguardados através de vários documentos internacionais ${ }^{67} \mathrm{e}$ a "nossa Carta Magna reservou 32 incisos do art. $5^{\circ}$, que trata das garantias fundamentais do cidadão, à proteção das garantias do homem preso. Existem ainda em legislação específica - a Lei de Execução Penal - os incisos de I a XV do art. 41" (ASSIS, 2007, p. 2007).

Art. 41 - Constituem direitos do preso:

I - alimentação suficiente e vestuários;

II - atribuição de trabalho e sua remuneração;

III - previdência social;

IV - constituição de pecúlio;

$\mathrm{V}$ - proporcionalidade na distribuição do tempo para o trabalho, o descanso e a recreação;

$\mathrm{VI}$ - exercício das atividades profissionais, intelectuais, artísticas e desportivas anteriores, desde que compatíveis com a execução da pena;

VII - assistência material, à saúde, jurídica, educacional, social e religiosa;

VIII - proteção contra qualquer forma de sensacionalismo;

IX - entrevista pessoal e reservada com o advogado;

$X$ - visita do cônjuge, da companheira, de parentes e amigos em dias determinados;

$\mathrm{XI}$ - chamamento nominal;

XII - igualdade de tratamento salvo quanto às exigências da individualização da pena;

XIII - audiência especial com o diretor do estabelecimento;

XIV - representação e petição a qualquer autoridade, em defesa de direito;

$\mathrm{XV}$ - contato com o mundo exterior por meio de correspondência escrita, da leitura e de outros meios de informação que não comprometam a moral e os bons costumes.

67 Declaração Universal dos Direitos Humanos, a Declaração Americana de Direitos e Deveres do Homem e a Resolução da ONU. 
Parágrafo único. Os direitos previstos nos incisos $\mathrm{V}, \mathrm{X}$ e $\mathrm{XV}$ poderão ser suspensos ou restringidos mediante ato motivado do diretor do diretor do estabelecimento (BRASIL, 2016, p. 1477).

O que se observa na atualidade é a inversão da política prisional, antes idealizada, agora corrompida. Essa constatação de Michel Foucault faz das suas observações pertinentes e verídicas quando processa o estudo da legislação penal. A prisão é a forma mais incompleta dessa evolução punitiva que inviabilizou os mecanismos de poder e gerou uma tensão social muito grande, pois agora os presos são vistos como uma ameaça constante pela sociedade que não sabe como detê-los, pois, a sociedade contemporânea se vê vítima de sua ação. Percebida mais do que nunca como um risco social.

A reformulação não passa por apenas um fator de crise, mas uma série de fatores que agem em conjunto e são justapostos. Rever a prisão significa observar que não se trata de uma "fábrica de delinquentes", mas um espaço onde o preso possa estar diretamente sendo revisto a partir de propostas de socialização e educação que realmente façam efeitos concisos. As esferas de poder precisam criar ações e propostas que vão de encontro com uma coerente política de restruturação ampla e em todos os níveis.

Trata-se de repensar a sua trajetória e buscar criar dispositivos que não levem a sujeição e os maus tratos, ou mesmo a indiferença, mas que haja em direção a promover uma readequação que busque atingir na vida dos presos, para que os mesmos não possam ser vistos mais como "animais", mas que se procure reintegrá-los a partir de práticas saudáveis que leve o seu bem estar e qualificação profissional. Dotar a prisão de ferramentas de inclusão através da educação, além disso, na meIhoria dos servidores com a devida capacitação possível e instrumentos de trabalho eficazes, procurando também rever certas liberdades que levam a intensificação de possíveis transtornos.

O governo brasileiro precisa criar medidas efetivas que vão de encontro com a melhoria das instituições penais, sendo capazes de exercer com rigor e ao mesmo tempo liberdade a sua função social. Cabe ao sistema prisional mudar uma série de posturas que inviabilizam a sua eficácia e encontrar formas que propiciem uma maior 
integração do preso tanto na vida de reclusão como na posterior liberdade. Fornecendo as ferramentas saudáveis e úteis, o preso na visão de Michel Foucault poderá se ver livre das relações de poder que o "sufocam" e que o veem apenas como um delinquente a ser apartado da sociedade e que o processo de recuperação do preso seja efetivamente realizado a contento de todos.

A prisão precisa estar na pauta das decisões políticas, ela é um verdadeiro problema social que precisa ser avaliado, pois o problema é de toda uma sociedade que se vê refém daqueles que passam pelo sistema prisional e voltam para a sociedade incapazes de se integrarem de forma positiva, reforçando estereótipos através de casos de reincidências. Numa avaliação sobre o sistema prisional brasileiro conclui-se que:

É notório a muitos que o sistema penitenciário brasileiro tem, nos últimos anos, sido debatido e vem ganhado notoriedade no meio acadêmico. Tem se discutido a sua importância enquanto base de ressocialização, por ser um ambiente distinto de punição onde ficam reclusos todos aqueles que estão em conflito com a lei [...] O sistema prisional do Brasil tem apresentado um grande desgaste com o passar dos anos e nos dias atuais chegou a um ponto precário com número de presos muito maior do que o de vagas, não existindo no país nenhuma unidade prisional, sob os cuidados do Estado, que apresentasse em suas dependências um número de presos inferior ao de vagas e nem sequer um cárcere onde o número de presos fosse igual ao de vagas: todas as instalações superlotadas. O sistema não tem conseguido alcançar sua meta que é o de recuperar e reintegrar o detento à sociedade, os índices de reincidência estão entre os maiores do mundo (ANDRADE; FERREIRA, 2015, p. 118).

A prisão se tornou para Michel Foucault em Vigiar e Punir, um projeto fracassado que tende a se tornar um problema ainda maior caso não seja solucionado. Torna-se necessário a criação de políticas que repensem o sistema prisional em toda a sua estrutura e refletir sobre sua capacidade institucional na condução e exercício da justiça. O sistema prisional brasileiro está pedindo socorro e sua reformulação passa pela efetiva melhoria física e profissional dos que trabalham nesses espaços, e na condução da ressocialização do preso mediante ações que cumpram seu papel de educar para a cidadania e não para o crime. 


\section{CONCLUSÃO}

Este artigo teve por finalidade conduzir uma discussão fundamental sobre a crítica da prisão na perspectiva de Michel Foucault que através da obra "Vigiar e Punir" traz à tona a evolução do sistema penal, desde o suplício até o surgimento da prisão. $O$ estudo aqui teve por finalidade percorrer esse caminho e demostrar como as práticas punitivas se tornaram uma estratégia de poder e sujeição dos indivíduos.

Primeiramente a punição recaia sobre o corpo, na forma de tortura e posterior morte, o processo era visto como se fosse um espetáculo público. A disciplina vem para abrir caminhos para a chegada da prisão, onde o corpo passa a ser atravessado pelas regras de como torna-lo "dócil" e "útil" perante a sociedade. O corpo é repensado como foco central, agora por sua vez agindo diretamente no psicológico do condenado, na duração da punição ao condenado com o seu enclausuramento. $A$ sociedade moderna chegou à conclusão de que é totalmente desumano a morte via tortura física, e que deveria se encontrar outros mecanismos de sujeição e criminalização. Mediante essa constatação a prisão emerge como uma forma de controle dos corpos do ponto de vista mais humanizado, conduzindo o preso ao encarceramento e permitindo a ele o retorno a sociedade através da ressocialização.

Mas o que se constata é que a prisão não tem cumprido o seu papel de agir de forma positiva sobre o indivíduo, mas de trazer mais problemas para a sociedade, se antes o sistema prisional era visto com uma solução, nos dias de hoje tem se tornado um problema grave e que precisa ser reformulado.

\section{REFERÊNCIAS}

ANDRADE, Ueliton Santos de; FERREIRA, Fábio Felix. Crise no sistema penitenciário brasileiro: capitalismo, desigualdade social e prisão. Revista Psicologia, Diversidade e Saúde, Salvador. 2015; 4 (1): 116-129. Disponível em: < https://www5.bahiana.edu.br/index.php/psicologia/article/view/471>. Acesso em: 08 de Mar. de 2017.

ASSIS, Rafael Damaceno de. A Realidade atual do sistema penitenciário brasileiro. Revista CEJ, Brasília, Ano XI, n. 39, p. 74-78, out./dez. 2007. Disponível:<http://www. cjf.jus.br/revista/numero39/artigo09.pdf>. Acesso em: 12 de Mai. de 2017.

BRASIL. Constituição Brasileira (1988). Constituição da república Federativa do Brasil: promulgada em 5 de outubro de 1988. Brasília, DF: Senado, 1988. 
BRASIL. Lei de Execução Penal. Lei n 7210 de 11 de julho de 1984.

BRÍGIDO, Edimar Inocêncio. Michel Foucault: Uma Análise do Poder. Rev. Direito Econ. Socioambiental, Curitiba, v. 4, n. 1, p. 56-75, jan./jun. 2013. Disponível em: $<$ http://www.egov.ufsc.br/portal/sites/default/files/direitoeconomico-12702.pdf>. Acesso: 16 de Abr. de 2017.

DOTTI, René Ariel. A crise do sistema penitenciário. Arq:IRD\Artigos de direitol Crise do sistema penitenciário 30/08/2003. Disponível em:< http://www.egov.ufsc.br/portal/ sites/default/files/anexos/12441-12442-1-PB.pdf>. Acesso em: 09 de Mai. de 2017.

FOUCAULT, Michel. Vigiar e Punir: nascimento da prisão. Rio de Janeiro: Editora Vozes, 2014.

FOUCAULT, Michel. Microfísica do poder. Rio de Janeiro: Edições Graal, 1979.

SOUSA, Noelma Cavalcante de; MENESES, Antonio Basílio Novaes Thomaz de. O poder disciplinar uma leitura em vigiar e punir. SABERES, Natal - RN, v. 1, n.4, jun 2010. Disponível em: <file:///C:/Users/user/Documents/Noelma\%20C\%20de\%20 Sousa $\% 20$ e $\% 20$ Antonio\%20Basilio\%20N.\%20T.\%20de\%20Meneses, \%20uma\%20 leitura\%20em\%20Vigiar\%20e\%20Punir,\%20p.\%2018-35.pdf>. Acesso em: 16 de Abr. de 2017. 


\section{A TERRITORIALIDADE HISTÓRICA DA IMIGRAÇÃO JAPONESA EM PRESIDENTE PRUDENTE/SP}

Adriano Amaro de Sousa ${ }^{68}$

$68 \quad$ Doutor em Geografia pela Universidade Estadual Paulista (Câmpus de Presidente Prudente/SP). Professor na Faculdade de Tecnologia de São Paulo (FATEC/Itaquaquecetuba-SP). Email: adramaro@yahoo.com.br.

\section{3}




\section{INTRODUÇÃO}

A imigração japonesa para o Brasil foi iniciada oficialmente a partir de 1908. Em virtude da recente abolição da escravidão, e diante das dificuldades crescentes com a imigração europeia, optou-se por trazer os japoneses, somente como mão-de-obra assalariada para as lavouras de café. Os japoneses, por outro lado, viam neste país esperanças de fazer fortuna e depois voltar. Imaginavam vir a ser donos de suas propriedades. Não se imaginavam como mão-de-obra barata. No início do século $X X$, o Brasil como país receptor, propicia incentivos à imigração, subsidiando o transporte: enquanto que outras nações, como por exemplo, os Estados Unidos, impunham restrições de caráter social, político e econômico à imigração japonesa.

O Brasil atraiu os imigrantes nipônicos estava sofrendo uma grave crise de braços na lavoura devido à instabilidade do imigrante europeu e necessitava urgente de trabalhadores para conter a superprodução cafeeira. Vejamos como Fausto (1977) descreve a possibilidade da entrada do imigrante japonês no Brasil.

[...] constante instabilidade do imigrante europeu tanto na fazenda como no próprio Estado (São Paulo), a redução da corrente imigratória em decorrência de fatores externos, como o decreto Prinetti , e de fatores internos provocados pela situação intensa da lavoura cafeeira em virtude da super produção e, finalmente, a possibilidade de abrir novo mercado para o café no Japão fizeram com que governo paulista se interessasse pelo imigrante japonês. (FAUSTO, 1977, p.105 )

Para os nipônicos a vida no Brasil era muito difícil, muitos desistiam da lavoura em virtude dos maus tratos, pelas péssimas condições de trabalho, moradia, e principalmente de remuneração. Segundo ENNES (2001), pode-se dividir a história da imigração japonesa no Brasil em três momentos: 1) o que corresponde aos primeiros anos de vida no Brasil, caracterizado por uma estratégia de trabalho temporário e de curta duração; 2) a que corresponde a uma fase posterior, marcada pelas mudanças quanto ao tempo de permanência no Brasil, conhecida como estratégia de trabalho temporário de longa duração; 3) o momento que correspondente à fixação permanente no Brasil, que pode ser caracterizado como a fase em que os imigrantes japoneses encontram a sua fixação no Oeste Paulista mais precisamente no município de Presidente Prudente/SP. 
Diante do exposto, o objetivo deste texto é analisar a geo-história da imigração japonesa no Brasil pela territorialização desse grupo étnico no município de Presidente Prudente/SP. Para tanto, o procedimento teórico-metodológico esteve balizado pelos aspectos bibliográficos pelos conceitos de imigração japonesa (ENNES, 2001; SAKURAI, 2000), Geo-história (SANTOS, 1977) e território (SAQUET, 2003). A estrutura do texto está dividida em duas partes: na primeira parte, iremos ver os aspectos teóricos balizado nos conceitos de imigração e território; já na segunda parte, buscaremos apresentar a geo-história da territorialidade dos japoneses em Presidente Prudente/SP - como veremos a seguir.

\section{IMIGRAÇÃO, TERRITÓRIO e TERRITORIALIDADE}

A geo-história do nipo-brasileiro pode ser analisada pela mobilidade populacional para o trabalho, que está diretamente envolvida na produção do território por meio da TDR (desterritorialização, reterritorialização e territorialização), devido os processos históricos desiguais e contraditórios determinados pela expansão do capitalismo e seus aspectos culturais.

Para Saquet (2003, p. 39),

[...] simultaneamente, à desterritorialização dá-se a reterritorialização. São processos intimamente ligados na dinâmica socioespacial. Na primeira, há perda do território inicialmente apropriado e construído, a supressão dos limites, das fronteiras, como afirma Raffestin (1984), e na segunda, uma reprodução de elementos do território anterior, pelo menos, em algumas das suas características. O velho é recriado no novo, num movimento que representa as forças sociais, em que um dos papéis do Estado é justamente a reterritorialização, acontecida com os italianos no Brasil e com as migrações internas.

O processo de produção do espaço geográfico apresentado na des-re-territorialização está eminentemente articulado com o Estado e com o capital, sendo que a desterritorialização dá-se, sobretudo, por fatores econômicos e políticos, de modo similar à re-territorialização. As pessoas migram condicionadas por um conjunto de elementos e processos.

A própria migração está fundamentada na territorialização como fruto de uma estratégia para tomar posse de um espaço geográfico. Já a des-territorialização é o abandono espontâneo ou forçado da territorialização. Por último, a re-territorialização é a construção de uma nova territorialização em um outro espaço, emergindo, assim, 
um novo território e nova(s) territorialidade(s).

A imigração japonesa no Brasil foi uma imigração de caráter familiar. As condições dessa dimensão familiar privilegiavam o espaço privado, sendo que, os aspectos culturais e produtivos tinham centralidade nesse tipo de sociabilidade. Tal sociabilidade dos sujeitos migrantes trazidos apresentava característica de trabalho autônomo e não o assalariado.

A exigência da imigração familiar é decorrência da experiência anterior com
os italianos, vindos também para os cafezais de São Paulo. As fugas das fa-
zendas e, portanto, o não-cumprimento do contrato significam prejuízos para
os fazendeiros, que querem evitar a repetição da experiência com os italia-
nos. A imigração japonesa em família é entendida por eles como um fator de
retenção e de não abandono do contrato (SAKURAI, 2000, p. 208).

Neste processo de mobilidade, a formação territorial orienta a explicação da sociedade e do território no tempo. Isto quer dizer que, a trama histórica da formação territorial explicita a complexidade espacial por meio do processo de apropriação e dominação do espaço geográfico. Por outro lado, Santos (1977) apresenta o conceito de formação socioespacial, que reside no fato de explicar teoricamente que uma sociedade só se torna concreta através de seu espaço. Espaço este que a sociedade produz e só é inteligível por ela mesma. Todavia, a categoria Formação Econômica Social dinamizada pelos economistas e sociólogos não tinha o trato da inclusão do espaço na análise da dinâmica social. Por isso, Milton Santos chama atenção para a Formação Socioespacial, pois não existe sociedade sem espaço. Desse modo, entendemos a Formação territorial pela dinâmica da abordagem do território balizada pelos ambientes construídos (paisagens) e pelos símbolos-culturais (signos), podendo ser visualizada pela geo-história.

A geo-história procura contribuir para os aspectos epistemológicos da geografia, em especial com os processos territoriais, em virtude das relações de poder, das redes de comunicações e das identidades tecidas historicamente (SAQUET, 2007). $\mathrm{Na}$ análise do industrial familiar nipo-brasileiro a Geografia Histórica ganha relevância se conjugada com a Geografia Econômica. Nossa ênfase é para os fatores e processos econômicos e culturais, historicamente determinados. 


\section{GEO-HISTÓRIA E TERRITORIALIDADE.}

A exigência da imigração familiar é decorrência da experiência anterior com os italianos, vindos também para os cafezais de São Paulo. As fugas das fazendas e, portanto, o não-cumprimento do contrato significam prejuízos para os fazendeiros, que querem evitar a repetição da experiência com os italianos. A imigração japonesa em família é entendida por eles como um fator de retenção e de não abandono do contrato (SAKURAI, 2000, p. 208).

A imigração familiar japonesa para o Brasil foi iniciada oficialmente no início do século $X X$, devido à dinâmica econômica do complexo cafeeiro, o fim da escravidão e as dificuldades crescentes com a imigração europeia. Por isso, optou-se por trazer os japoneses como mão-de-obra assalariada para as lavouras de café. Ademais, para Sakurai (2007), o país incentivou a imigração nipônica subsidiando o transporte, enquanto outras nações (Estados Unidos, Canadá e Peru), impunham restrições de caráter social, político e econômico.

No dia 24 de abril de 1908, partem do porto de Kobe os primeiros imigrantes japoneses a bordo do navio Kasato Maru com destino ao Brasil. Vieram, no total, 781 pessoas contratadas e 12 imigrantes livres, que foram recrutados no Japão pela empresa Kokoku Shokumin Kaisha (Companhia de Colonização Japonesa). Essa primeira leva de imigrantes desembarcou no porto de Santos no dia 18 de junho, sendo levada para a hospedaria do imigrante e, posteriormente, encaminhada para as fazendas de café no interior do Estado de São Paulo (SAITO, 1961).

A imigração japonesa no Brasil concentrou-se, principalmente, no estado de São Paulo, mais especificamente na região metropolitana de São Paulo, na área da chamada Mogiana e no Oeste Paulista. Além disso, instalou-se também na Amazônia (colônia Acará) e no Pará (colônia Tomé Açu) em meados da década de 1930, onde cresceram cultivando cacau, arroz, milho, mandioca, pimenta do reino e outros produtos (SAITO, 1961).

Dentro deste contexto, a mobilidade espacial do imigrante japonês no Oeste Paulista se deu inicialmente pela área cortada pela Estrada de Ferro Noroeste do Brasil, composta pelos municípios de Bauru, Lins, Cafelândia e Araçatuba, que foi a primeira região a agregar os colonos japoneses em 1930, que serviram de força de trabalho para o cultivo do café. Outra região, aquela da Estrada de Ferro Sorocaba- 
na, estava representada pelas cidades de Assis, Rancharia, Presidente Prudente e Presidente Epitácio/SP, que teve grande dinamismo econômico na década de 1940 pela cotonicultura. A Alta Paulista, por sua vez, tinha grande contingente de imigrantes nipônicos que para lá foram a partir do final da década de 1930, também devido ao cultivo de algodão (SAKURAI, 1995).

Embora a territorialização da imigração japonesa para o Brasil tenha se iniciado em 1908, somente na década de 1930 é que, efetivamente, ocorreu a fixação dos nipônicos no município de Presidente Prudente ${ }^{69}$. Em 1918, por exemplo, havia duas famílias localizadas na zona rural (ABREU, 1972). Somente uma década depois é que chegou um contingente significativo. A territorialização dos imigrantes isseis foi favorecida pela dinâmica econômica comandada pela produção agrícola, quando eles se inseriam como arrendatários ou sitiantes, o que foi facilitado pela frente de expansão da cafeicultura. Com isso, o cultivo do café possibilitou o avanço econômico da região para os pioneiros, atraindo migrantes de várias nacionalidades e, entre eles, o trabalhador japonês ${ }^{70}$. Porém, a crise internacional de 1929 paralisou a produção da lavoura cafeeira para o mercado internacional (SOUSA, 2007/2010).

As primeiras famílias nipônicas vieram das cidades de Hokkaido, Fukuoka, Fukushima, Ryogo e Okinawa. Porém, grande parte desses imigrantes já se encontravam no Brasil, sobretudo nas colônias de Bastos, seguida de Paraguaçu Paulista e de diversos lugares do interior de São Paulo (BUTUSGAN, 1980). Todos eram colonos na agricultura e almejavam acumular uma poupança para voltar ao lugar de origem, o que não aconteceu. Nessa sua saga por mobilidade-permanência, procuraram regiões com terras baratas e férteis na "boca do sertão"71 para comprar lotes rurais no Brasil, criando raízes e se territorializando efetivamente no estado de São Paulo, tornando Presidente Prudente como o território de oportunidades ${ }^{72}$. Assim, a

69 O município foi fundado em 14 de setembro de 1917, originou-se no âmbito do complexo cafeeiro, através do loteamento de terras às margens da Estrada de Ferro Sorocabana, ocasionando a formação de dois núcleos urbanos: Vila Goulart e Vila Marcondes que, posteriormente, formariam a cidade (ABREU, 1972).

70 O imigrante japonês não foi camponês, no máximo lavrador, porque não era posseiro e nem fez parte da luta pela terra, como o trabalhador brasileiro.

71 Denominação para as cidades que, ao longo das ferrovias, eram as mais avançadas no território, mesmo que por pouco tempo.

72 O território em Gottmann (1973) aborda o mesmo como "plataforma para oportunidade do que como um abrigo para a segurança" (p. 534).

198 
permanência do imigrante japonês se deu pelo trabalho, que o mesmo realizou no cultivo do algodão ${ }^{73}$ efetivando sua territorialização pelo habitat e pela plataforma de oportunidade, tendo centralidade na pequena propriedade privada rural. Foi com esta cultura que alguns nipo-brasileiros conseguiram ascensão social, alguns deles conseguiram se tornar capitalizados e investiram na educação dos filhos por meio de uma profissão especializada visando a mudança de status e objetivando ganhar dinheiro em atividades urbanas (SOUSA, 2019).

O núcleo urbano prudentino, em meados de 1950, fixou os japoneses que buscavam o trabalho autônomo no comércio ou nos serviços, sendo o município era pólo regional que concentrava população híbrida e boa produção industrial (beneficiamento de produtos primários, como café, algodão e amendoim) e serviços gerais (manutenção e consertos). Dos autônomos nipo-brasileiros alguns se estabeleceram como micro-empresários constituindo oficinas, lojas, bares, armazéns e pensões. Entre os pequenos empreendimentos nikkeis havia empresas bancárias (inter)nacionais japonesas (exemplos: Casa Bancária Tozan, Banco Noroeste e Banco América do Sul) (SOUSA, 2010).

Não obstante, a educação para os nipônicos era um fator estratégico de desenvolvimento e permanência no território. Dessa forma, a colônia prudentina logo que se organizou em associação implantou uma escola no centro do núcleo urbano. Segundo Santos (2007), o Colégio São Paulo, em 1938, passou a ser dirigido pela colônia japonesa, mais precisamente pela professora nissei Akiko Nishi. Essa escola fazia a relação entre a colônia e a sociedade prudentina por ser a única escola secundária local. Porém, no período da II Guerra Mundial foi retirada a administração da associação nipo-brasileira porque o Brasil declarou guerra ao Japão e aos países do eixo. Depois da guerra, a professora pôde reassumir a escola que estava em insolvência financeira, o que levou à sua venda ao Grupo Educacional Esquema. Essa experiência bem-sucedida de mais de 30 anos de administração de uma escola faria o grupo criar outra escola de nível médio (colegial) para atender a colônia japonesa e a comunidade prudentina, surgindo o Colégio ACAE Anglo, direcionado ao preparo 73 "A identificação entre algodão e pequena propriedade deve ser acrescentado um terceiro elemento: o japonês. Com efeito, o grosso da imigração japonesa desembarcou em Santos no exato momento em que os agricultores paulistas lançavam-se na cultura do algodão" (MONBEIG, 1984, p. 288). 
de jovens aos vestibulares (SANTOS, 2007).

Nessa perspectiva, o processo de urbanização em Presidente Prudente estava associado ao incipiente processo de industrialização local/regional, comandado pelo setor de comércio e de serviços dinâmicos que, ao longo do espaço tempo, se configurou em uma cidade com alguns serviços complexos, dentre eles a educação, a saúde, o imobiliário, o financeiro e o agronegócio. Com isso, fizera atrair a necessidade de profissionais liberais especializados.

\begin{abstract}
Esse movimento de fundo, no território e na sociedade, vai dar, em consequência, uma nova urbanização brasileira. Um dos elementos fundamentais de sua explicação é o fato de que aumentou no Brasil, exponencialmente, a quantidade de trabalho intelectual. Não se dirá, com isso, que a população brasileira tenha se tornada culta, mas tornou-se mais letrada. $\mathrm{O}$ fato de ter-se tornado mais letrada está em relação direta com a realidade que vivemos nesse período científico-técnico, onde a ciência e a técnica estão presentes em todas as atividades humanas. Nessas condições, a quantidade de trabalho intelectual solicitada é enorme, mesmo porque a produção material diminuiu em benefício da produção não material. Tudo isso, conduz à amplificação da terceirização que, nas condições brasileiras, quer dizer também urbanização (SANTOS, 2013, p. 53-54).
\end{abstract}

Diante desse quadro de urbanização ímpar e dinâmica no Oeste Paulista, os nipo-brasileiros buscaram êxito econômico e status social por meio dos empregos urbanos (operários na indústria, funcionários públicos, comerciários e prestadores de serviços). No setor industrial de alimentos, bebidas e molhos se destacaram as famílias Nagaya, Funada, Oki, Fukuhara e Honda ${ }^{74}$. Em alguns casos, os descendentes de imigrantes japoneses também tiveram relevo nas atividades de profissionais liberais (médicos, engenheiros, advogados e dentistas) e nas atividades intelectuais (professores universitários, escritores, artistas etc.) devido aos investimentos das famílias na educação dos filhos (SOUSA, 2007, 2010).

De modo geral, os resultados dessa conquista ocorreram pela organização do trabalho laboral regida pela disciplina da cultura nipônica. Também foi perceptível a participação dos nipo-brasileiros em nichos de atividades comerciais e de prestação de serviços com características mais refinadas e técnicas/tecnológicas: fotográfica,

$74 \quad$ A indústria nipo-prudentina iniciou suas atividades na década de 1940, de forma rudimentar quase que fabril-artesanal com o processamento em escala industrial das bebidas alcoólicas pelas empresas Bebidas Wilson (Motoichi Oki) e Bebidas Astecas (Keniti Fukurara e Massami Honda). E, também, pelas Bebidas Funada (Mampei Funada e Keniti Funada) com o produto refrigerante. Por fim, a Indústria Sakura (Suekichi Nakaya) com molho de soja e outros produtos típicos da culinária japonesa (DUNDES, 1997; SOUSA, 2010). 
ótica, joalheria e relojoaria. Ao longo do tempo-espaço, a ascensão social de alguns nipo-brasileiros ocorreu "graças" ao grau de especialização do trabalho e pelo nível técnico de instrução que teve uma paulatina mobilidade social. É neste contexto que compreendemos a mobilidade social e espacial do nikkei no Oeste Paulista (SOUSA, 2019).

Com a aposta das famílias na educação dos filhos viu-se o encaminhamento dos nikkeis para se transformarem em profissionais liberais especializados, o que teve início por volta da década de 1950, estendendo-se até a década de 1980 no Brasil, confirmando o movimento do campo para a cidade. Esse pode ser considerado, também, um período de mobilidade ascendente na geo-história recente dos nikkeis, pois as famílias que se (re)territorializam no município teve uma mobilidade espacial e posições socioeconômicas na construção e reprodução de representações sociais de Presidente Prudente/SP.

\section{REFERÊNCIAS}

ABREU, D. S. Formação histórica de uma cidade pioneira paulista: Presidente Prudente. Presidente Prudente: FFCLPP, 1972.

BUTUSGAN, Sumi. Os nisseis e a busca de sua integração na sociedade brasileira: um grupo referencial - o Centro Cívico Nissei de Presidente Prudente. Presidente Prudente: 1973 (Tese de doutorado).

ENNES, M. A. A construção de uma identidade inacabada: nipo-brasileiros no interior de São Paulo. São Paulo: Unesp, 2001.

DUNDES, Ana Claudia. O processo de (des) industrialização e o discurso desenvolvimentista em Presidente Prudente. Presidente Prudente/SP: FCT/Unesp, 1998. (Dissertação de Mestrado em Geografia).

KOKETSU, Toshio. Inicio da colonização japonesa em Presidente Prudente. In: SHICASHO, Emika T. A saga dos imigrantes japoneses em Presidente Prudente. Presidente Prudente: Gráfica Impress, S/D.

MONBEIG, P. Pioneiros e fazendeiros de São Paulo. São Paulo: Hucitec, 1984.

RAFFESTIN, Claude. Por uma geografia do poder. São Paulo: Ática, 1993.

SAITO, Hiroshi. A presença japonesa no Brasil: estudo de mobilidade e fixação. 
São Paulo: USP, 1961.

SAITO, Hiroshi \& MAEYAMA, Takashi. Assimilação e integração dos japoneses no Brasil. Petrópolis: Ed. Vozes, 1973.

SAKURAI, Célia. Os japoneses. São Paulo: Contexto, 2007.

SAKURAI, Célia. Imigração japonesa para o Brasil: um exemplo de imigração tutelada. In: Fausto, Boris. (Org.). Fazer a América: imigração em massa para a América Latina. Edusp, 2000.

SAKURAI, Célia. Primeiros pólos da imigração japonesa no Brasil. São Paulo: Revista USP, n. 27, set/out/nov, p. 32-45, 1995.

SANTOS, M. A urbanização brasileira. São Paulo: Edusp, 2013.

SANTOS, M. Sociedade e espaço: a formação social como teoria e como método. Boletim Paulista de Geografia, São Paulo, n. 54, p. 81-99, 1977.

SANTOS, Valdery. Pioneiros da imigração japonesa da Alta Sorocabana. 2007.

SAQUET, Marcos Aurélio. Abordagens e concepções de território. São Paulo: Expressão Popular, 2007.

SAQUET, Marcos Aurélio. Os tempos e os territórios da colonização italiana: o desenvolvimento econômico da Colônia Silveira Martins (RS). Porto Alegre: Ed. EST, 2003/2001.

SOUSA, Adriano Amaro de. A geografia histórica da industrialização regional no Oeste Paulista: o exemplo das industriais dos municípios de Marília/SP e de Presidente Prudente/SP. In: Ivânio Folmer; Thales Silveira Souto. (Org.). Desenvolvimento regional: política, planejamento e economia. $1^{\circ} \mathrm{ed}$. Santa Maria/RS: Editores Arco, 2021, p. 221-233.

SOUSA, A. A. Território e mobilidade social: o nikkei como profissional liberal no município de Presidente Prudente/SP. Presidente Prudente: FCT/Unesp, 2010 (Tese de Doutorado em Geografia).

SOUSA, A. A. A dimensão geo-histórica do industrial nipo-brasileiro no contexto do Oeste Paulista. In: SPOSITO, E. S.; BOMTEMPO, D. C.; SOUSA, A. A. (Org.). Geografia e migração: movimentos, territórios e territorialidades. 1ed. São Paulo SP: Expressão Popular, 2010a, p. 177-199. 
SOUSA, A. A. O vôo do tsuru: o empresariado nipo-brasileiro. Presidente Prudente: FCT/Unesp, 2010b. (Dissertação de Mestrado em Geografia)

SOUSA, A. A. A formação histórica do Oeste Paulista: alguns apontamentos sobre a introdução da imigração japonesa. Presidente Prudente/SP: Geografia em Atos (Online), v.8, p. 1-10, 2009.

SOUSA, A. A. A territorialização dos imigrantes japoneses na Alta Sorocabana. Presidente Prudente: Revista Formação, n. 14, vol. 2. p. 119-129, 2007.

SPOSITO, E. E.; BOMTEMPO, D. C.; SOUSA, A. A. Geografia e migração: movimentos, territórios e territorialidades. São Paulo/SP: Editora Expressão Popular, 2010.

SUZUKI, Teiiti. Mobilidade geográfica de imigrantes japoneses. In: Assimilação e integração dos japoneses no Brasil. Petrópolis: Ed. Vozes, 1973.

VIEIRA, Francisca Isabel Shurig, $\mathbf{O}$ japonês na frente de expansão paulista. São Paulo: 1973 (tese de doutorado). 


\section{APLICAÇÃO DO MÉTODO LANCASTER NAS AULAS DE PRIMEIRAS LETRAS (ALCÁNTARA, MA - $\left.\right|^{\circ}$ QUARTEL DO SÉCULO XIX)75}

Ricardo Costa de Sousa ${ }^{76}$

75 Este texto foi apresentado no IX Encontro Maranhense de História da Educação - EMHE, 2016, São Luís. Para compor essa obra o texto passou por revisão, acréscimos de dados, bem como por supressões. Tais procedimentos foram necessários para que pudesse atender aos critérios adotados por essa editora.

76 Pós-doutorando em Educação pela Universidade do Oeste de Santa Catarina (UNOESC). Doutore Mestre em Educação pela Universidade Federal do Rio Grande do Sul (UFRGS). Especialista em Gestão de Políticas Públicas em Gênero e Raça pela Universidade Federal do Maranhão (UFMA). Pedagogo pela Faculdade de Educação Santa Teresinha (FEST). Militante do Centro de Cultura Negra Negro Cosme (CCNNC) em Imperatriz (MA). E-mail: ricardo_lut@hotmail.com

\section{4}




\section{INTRODUÇÃo}

A História da Educação na Província de Alcântara, Estado do Maranhão do século XIX é um espaço de inúmeras possibilidades de investigações, pelo fato de que a Província carrega as marcas de um passado escravocrata em que a educação era apenas reservada a aristocracia. É nesse cenário que se faz relevante discutir a memória da instrução pública.

Este texto procura investigar o Método Lancaster nas Aulas de Primeiras Letras na Província de Alcântara - MA (1825-1841). De modo que se pretende, num primeiro momento, descrever o desenrolar da Instrução Pública em Alcântara apontando a contribuição da sociedade alcantarense na doação dos subsídios literários, mesmo estes tendo sido alvo de inúmeras fraudes, resultando em graves prejuízos aos professores e aos cofres públicos, bem como apontar os limites legais como a Constituição de 1824, e mais tarde, com a aprovação da Lei de 15 de outubro de 1827 surge o primeiro dispositivo legal que aborda o Método Lancaster. No segundo momento, destaca-se a presença do Método Lancaster nos mapas de matrículas, estatístico e de frequência de alunos que frequentaram as Aulas de Primeiras Letras, atentando para a infrequência de alunos em virtude da ajuda aos pais na lavoura. A organização dos mapas enquanto estrutura consta: adiantamento, conduta dos alunos e, a organização das turmas em classes de leitura, escrita e aritmética, conforme sugere o Método Lancaster. A pesquisa foi realizada em referenciais do campo da História da Educação, tais como: Bastos (2005) que aborda como o Método Lancaster deveria ser aplicado, Cruz (2008) destaca quem teria acesso à instrução, Faria Filho (2007) escreve sobre os debates da criação de leis a respeito da Instrução Pública, Viveiros (1953) contextualiza a Instrução Pública em Alcântara, dentre outros.

Contou-se também com a pesquisa em documentos (nos mapas de matrículas, estatístico e de frequência) acondicionados no Arquivo Público do Estado do Maranhão (APEM), na cidade de São Luís (MA), no intuito de realizar um diálogo entre os dados obtidos nessas fontes bibliográficas e documentais. A pesquisa está amparada no campo da História da Educação, sob os pressupostos da História Cultural. Conclui-se que a pesquisa sinalizou na época à necessidade de implementação do Método Lancaster em virtude do quantitativo de alunos nas Aulas de Primeiras Letras 
na Província de Alcântara, mesmo tendo em vista a falta de prédios adequados e, principalmente a falta de materiais pedagógicos para sua implementação.

\section{O desenrolar da Instrução Pública em Alcântara}

No Brasil, durante mais de dois séculos os jesuítas criaram e mantiveram quase que com exclusividade a instrução, que, teria na Companhia de Jesus seu principal agente educador/civilizador. Mesmo em meio a graves problemas, como os da organização das capitanias, da luta contra a invasão de inimigos externos e da liberdade dos índios. De qualquer modo, se por um lado, a ação educadora/civilizadora dos jesuítas contribuiu para destruir a cultura dos nativos, por outro lado, estes foram responsáveis pela educação da elite. De certo, foi no Estado do Maranhão, em 1759, ano da expulsão dos jesuítas, que Pombal condenou o sistema escolar da Companhia de Jesus e criou as primeiras escolas públicas na colônia (escolas régias) e procurou, depois, enaltecer a profissão do magistério com o decreto de 14 de julho de 1775, que declarava os professores régios merecedores de privilégios e homenagens em razão da nobreza de seu ofício (VIVEIROS, 1953).

Para a manutenção dessas escolas, foi instituído pelo decreto de 10 de novembro de 1772 um imposto sobre diversos gêneros de consumo, o qual teve a denominação de subsídio literário. No Maranhão, a cobrança do subsídio literário não foi efetuada até 1786 , resultando em graves prejuízos aos professores, aos cofres públicos (MOURA, 2000; VIVÊIROS, 1953).

Houve inúmeras dificuldades na implementação das aulas régias, entre elas estão implicados o subsídio literário e a precária formação de professores, assim como a escassez destes em condições de implementar a pedagogia dos padres jesuítas; a insuficiência de recursos, pois, a Colônia não contava com uma estrutura arrecadadora capaz de garantir o subsídio literário para financiar as aulas. Assim, o ensino primário nas capitais do Brasil tornou-se deplorável, pois, "entre a expulsão dos jesuítas em 1759 e a decretação do subsídio literário em 1772, 13 anos de absoluta inação no campo da instrução" (MOURA, 2000, p. 70).

Era grande o quantitativo de estudantes que faziam o intercâmbio intelectual de Alcântara para Coimbra, a fim de que, os jovens alcantarenses aprendessem as profissões de topografia, hidráulica, medicina, contabilidade e outras. Em 1800, as

\section{6}


Câmaras apresentavam um déficit no subsídio literário para manter esses jovens na Europa, mesmo depois de ser lançando um novo imposto sobre o algodão (VIVEIROS, 1953).

Todavia, com a conquista da Independência em 1822, com base em acordos políticos de interesse da classe dominante e a promulgação da primeira Constituição do Império, coube à Assembleia Constituinte e Legislativa propor uma legislação particular sobre a instrução pública primária e secundária em todo o país, com o objetivo de organizar a educação nacional. A Constituição do Império outorgada em 25 de março de 1824, que durou todo o período imperial, destacava no Art. 179, parágrafo 32, com respeito à educação, a seguinte incumbência: "A instrução primária é gratuita para todos os cidadãos". Para dar conta da referida lei no que tange à instrução nacional, principalmente os dois primeiros meses de 1826 foram fecundos em reclamações e iniciativas em prol da instrução popular (BRASIL. 1824). Contudo, três anos após a Constituição é que foi votada a Lei de 15 de outubro de 1827, cujo espírito era dar realidade a esse princípio constitucional. Essa lei "é o primeiro dispositivo legal que aborda a questão de método do ensino no nosso país, tornando obrigatório nas escolas brasileiras o ensino mútuo, preconizado, então, na Europa", por Joseph Lancaster e André Bell (VIVEIROS, 1953, p. 07).

Conforme a Lei de 15 de outubro de 1827, no Art. $4^{\circ}$ determinava que "As escolas serão do ensino mútuo nas capitais das províncias; e serão também nas cidades, vilas e lugares populosos delas, em que for possível estabelecerem-se". Continua, no Art. $6^{\circ}$. Os professores ensinarão a ler, escrever, as quatro operações de aritmética, prática de quebrados, decimais e proporções, as noções mais gerais de geometria prática, a gramática de língua nacional, e os princípios de moral cristã e da doutrina da religião católica e apostólica (BRASIL. 1824). De um modo geral, a lei não deu os resultados esperados, pois de 14 escolas passou-se a 24, das quais 2 eram na capital, e as restantes distribuídas no interior do estado, sendo uma escola no município de Alcântara (VIVEIROS, 1953).

Em relação à implantação do Decreto de 1827, Bastos (2005, p. 42) diz que "esbarrou em uma série de obstáculos: a falta de adequados prédios escolares e materiais necessários à adoção do método mútuo; o descontentamento dos mestres, pela falta de proteção dos poderes públicos e pela falta de recompensa pecuniária". 
Nesse sentido, houve por parte do poder público um completo descaso com relação aos prédios escolares, disponibilização de livros didáticos e demais itens necessários para a aplicação do método exigido por lei.

$\mathrm{O}$ ato Adicional de 12 de agosto de 1834 teve caráter acentuadamente descentralizador, remetendo a cada província o poder de elaborar, criar e implementar o seu próprio regimento. Dessa forma, cada Assembleia Legislativa teria a incumbência de legislar e criar estabelecimentos próprios, além de regulamentar e promover a educação primária e secundária (BRASIL.1834). Dentro desse contexto, "o Estado Imperial Brasileiro e as Províncias do Império, sobretudo a partir do Ato Adicional de 1834, foram pródigos em estabelecer leis referentes à instrução pública" (FARIA FILHO, 2007, p. 137).

A respeito da criação de leis para a instrução pública, é a partir de 1834, portanto, que surgiram as primeiras escolas criadas pelo legislador maranhense. A Assembleia Provincial, logo na sua primeira sessão de 1835, reunindo-se quando já ocupava a presidência da Província o Dr. Antonio Pedro da Costa Ferreira, mais tarde Barão de Pindaré, não descurou do magno problema (VIVEIROS, 1953).

Em 1838, duas outras leis foram votadas pela Assembleia no sentido de melhorar instrução pública na província, as quais receberam os números 76 e 77 e a data de 24 de junho. Sancionou-as Vicente Tomaz Pires de Figueiredo Camargo, que envia à França Felipe Benicio Oliveira Condurú que, regressando à Província, lecionou a partir de janeiro de 1840 na Escola Normal a prática do método Lancastrino. Entretanto, os professores de Rosário, São João de Cortes - Freguesias de Alcântara e outras localidades não viram com bons olhos esse curso de aperfeiçoamento (VIVEIROS, 1953). Bastos (2005, p. 43) faz menção à "primeira Escola Normal do Brasil (18351851), na capital da Província do Rio de Janeiro - Niterói, com o intuito de preparar os futuros mestres do domínio teórico-prático do método monitorial/mútuo".

Somente em 1840, foi criada a Escola Normal no Estado do Maranhão, o que possibilitou formar no próprio Estado um quadro de professores, até ali encaminhados para a cidade de Niterói. Alguns destes professores passaram a exercer o magistério na Casa dos Educandos Artífices - CEA, que foi criada pela lei da Província do Maranhão $n^{\circ} 105$, de 23 de agosto de 1841, na presidência do Dr. João Antonio de Miranda. "O estabelecimento era destinado a receber moços desvalidos, de prefe- 
rência os enjeitados, e dar-Ihes instrução e primeiras letras e um ofício" (VIVEIROS, 1953, p. 15).

\section{O método Lancaster nos mapas de matrículas, estatísticos e de frequência}

A pesquisa realizada em documentos - mapas de matrícula, estatístico e de frequência - da Secretaria de Governo, reunidos e acondicionados no Arquivo Público do Maranhão sob o título "Câmara Municipal" e "Instrução Pública" de Alcântara, possibilitou evidenciar a referência ao Método Lancaster adotado nas Aulas de Primeiras letras em Alcântara entre os anos de 1825 a 1841.

Procurou-se iniciar a investigação nos documentos da Câmara Municipal de Alcântara a partir da matrícula de 33 alunos entre os anos de 1825 a 1832 que ingressaram na Aula Nacional da llustríssima Câmara de Alcântara, pelo então professor João de Deos Soares de Mello. No que tange às observações contidas nesses mapas, encontra-se a nitidamente o grande quantitativo de faltas por aluno matriculado. Conforme esclarece o documento, "as faltas são motivadas por causa da maior parte dos alunos serem muito pobres e serem obrigados, segundo a necessidade, irem ajudar a seus pais desmancharem as suas rocinhas a fim de terem alguma farinha" como também, "as faltas são motivadas por causa de moléstias (ALCÂNTARA,1832 [s.p]).

Observações como estas estão presentes em outros documentos, nos quais se evidenciam o grande quantitativo de faltas motivadas por doenças ou por necessidade de ajudar os pais na lavoura. A esse respeito, Veiga (2008, p. 06) afirma que, "para os estudos do século XIX podemos acrescentar a escola pública como um dos espaços de presença das crianças pobres e particularmente de produção da identificação "aluno pobre"'. Mesmo o presidente da província Eduardo Olímpio Martins, mostrar-se preocupado quanto à instrução pública dos mais pobres e desvalidos, excluía os escravos, pois não eram considerados cidadãos, conforme determinou a legislação provincial (CRUZ, 2008; VIVEIROS, 1953).

Em 28 de janeiro de 1832, consta no mapa de frequência a lista de nomes e sobrenomes de 12 alunos que foram admitidos na aula particular do professor Ventura Henrique Ferreira entre os anos 1829 a 1832. Em observação escrita, o professor 
diz que o aluno "escreve cursivo [ilegível], carta de sílabas, linhas e bastardo". Dessa forma, as observações contidas nesse mapa, como em muitos outros dizem respeito somente às formas de escritas (ALCÂNTARA, 1832 [s.p]). Em outra escola particular de primeiras letras, constam agora informações relativas à doutrina, 'os alunos sabem até os mandamentos, até o credo e salve rainha' (ALCÂNTARA, 1838 [s.p]).

Os dois mapas da escola particular de Alcântara demonstram o Método Lancaster vigente, a partir da sua organização em termos das classes de leitura, escrita e aritmética. Em relação ao ler, escrever e contar, Faria Filho (2007, p. 139) assegura que "agregaram-se outros conhecimentos e valores, que a instituição escolar deveria ensinar às novas gerações, sobretudo às crianças". Conteúdos como "rudimentos de gramática", de "língua pátria", de "aritmética" ou "rudimentos de conhecimentos religiosos". Já em relação às informações concernentes à doutrina, o Método Lancaster propunha uma educação tutelada pelo ideário da religião católica, uma vez que, pela Constituição de 1824, não havia laicidade no Brasil. De fato, é evidente nos mapas a referência ao ensino da doutrina católica.

Bastos (2005, p. 36) esclarece "a leitura, para os menores da primeira classe, consiste em aprender o alfabeto e traçar as letras sobre a areia; na segunda classe, os alunos são iniciados nas sílabas de duas letras, que escrevem sobre a ardósia". Contudo, "na terceira, fazem a combinação com três letras; na quarta, trabalham as palavras com várias sílabas; na quinta, começam a ler, somente na sexta classe leem corretamente" (BASTOS, 2005, p. 36). Assim, a autora ajuda a compreender as informações do método utilizado nas escolas alcantarenses partindo do pressuposto de que, a cada classe, é averiguado o conhecimento do aluno.

A partir da pesquisa realizada, constatou-se que o Método Lancaster foi utilizado entre 1825 a 1841, apesar de que somente em 17 de dezembro de 1849 pode-se encontrar o Regulamento de Instrução Pública no Maranhão. Assim, o regulamento no Art. $1^{\text {a }}$ diz que "os Professores Públicos de primeiras Letras da Província servir-se-ão no ensino da Mocidade do Método individual, simultâneo, e lancastrino, segundo a frequência dos seus alunos". O documento segue apontando no Art. $2^{\mathrm{a}}$ "Os que tiverem de dez a trinta e nove alunos ensinarão pelo Método Individual [...]. Art. $3^{\text {a }}$ Os que tiverem de quarenta a setenta e nove alunos ensinarão pelo Método Simultâneo [...]. Art. $4^{\mathrm{a}}$. Os que tiverem de oitenta a cento e sessenta alunos ensinarão pelo Mé-

\section{0}


todo Lancastrino [...]" (MARANHÃO. 1849).

Segundo Faria Filho (2007, p. 141), o método denominado lancasteriano ou mútuo, atribuído ao educador inglês Joseph Lancaster, "tem como característica principal o fato de utilizar os próprios alunos como auxiliares do professor". Desse modo, entende-se que o professor ensinava uma lição a um determinado grupo de alunos, considerados "amadurecidos e/ou inteligentes" e os dividia em grupos com aqueles que ainda não receberam a lição.

Em 1835, constam 78 alunos matriculados na classe de primeiras letras, mas as observações permanecem as mesmas do mapa anterior. No mesmo ano, já em 10 de abril, a entrada de 25 novos alunos, somando 90 matriculados. Contudo, em 01 de julho, permanece o quantitativo inicial de 78 alunos (ALCÂNTARA, 1832 [s.p]). Neste mapa, se evidencia o quantitativo expressivo de alunos, requerendo a aplicação do Método Lancastrino. Aqui, ainda cabe dizer que o inspetor da Instrução Pública ficava com a responsabilidade de fiscalizar a aplicação do método e conferir as informações dos mapas.

Em 1841 constam 60 alunos entre 6 e 9 anos de idade matriculados nas aulas de primeiras letras. No referido mapa consta que, dos 60 alunos matriculados, 54 "nada sabem", o que representa um quantitativo elevado de alunos (90\%) que não tiveram contato com a leitura e escrita antes de ingressar na escola, enquanto que os outros 6 (10\%), que já "soletravam bem", haviam sido iniciados na leitura e escrita em espaços não escolares (ALCÂNTARA, 1841 [s.p]). Nesse sentido, "não podemos considerar que apenas aqueles, ou aquelas, que frequentavam uma escola fora do ambiente doméstico tinham acesso às primeiras letras", pois, os indícios são de toda ordem (FARIA FILHO, 2007, p. 145).

\section{CONSIDERAÇÕES FINAIS}

Primeiramente, cabe registrar que, a investigação centrou-se no campo da História da Educação sob os pressupostos teóricos e metodológicos da História Cultural. A partir dessa delimitação foi possível investigar o Método Lancaster nas Aulas de Primeiras Letras na Província de Alcântara - MA (1825-1841), atentando para o desenrolar da Instrução Pública em Alcântara e da contribuição da sociedade alcantarense na doação dos subsídios literários. 
Para tanto, foram pesquisados mapas de matrículas, estatístico e de frequência de alunos que frequentaram as Aulas de Primeiras Letras e demonstraram a presença do Método Lancaster dado o quantitativo de alunos. Contudo, demonstraram ainda que, havia um grande quantitativo de alunos infrequentes em virtude de fatores diversos, como ajudar os pais nas lavouras, constando no final do documento.

Por fim, a investigação indicou que, na época, à necessidade de implementação do Método Lancaster em virtude do quantitativo de alunos nas Aulas de Primeiras Letras na Província de Alcântara, mesmo tendo em vista a falta de prédios adequados e, principalmente a falta de materiais pedagógicos para sua implementação, para o contexto da época (1825 a 1841).

\section{REFERÊNCIAS}

ALCÂNTARA, Câmara Municipal. Aula Nacional da llustríssima Câmara de Alcântara: reg. 031, (map 04): Alcântara, 1832.

ALCÂNTARA, Câmara Municipal. Informações dos discípulos da aula de primeiras letras em Alcântara: reg. 054 e 045 (map 04): Alcântara, 1832.

ALCÂNTARA, Câmara Municipal. Mapa dos alunos da aula de primeiras Letras em Alcântara: reg. 062, (map 04): Alcântara, 1832.

ALCÂNTARA, Câmara Municipal. Relação dos alunos que frequentaram a escola particular de primeiras letras em Alcântara: reg. 036, (map 04): Alcântara, 1838.

ALCÂNTARA, Instrução Pública. Mapa estatístico dos alunos que frequentam a aula de primeiras letras em Alcântara: reg. 118, (map 06): Alcântara, 1841.

BASTOS, M.H.C. O ensino monitorial/mútuo no Brasil (1827-1854). In: STEPHANOU, Maria; BASTOS, M.H.C. Histórias e memórias da educação no Brasil (orgs). Vol. II. Petrópolis: Vozes, 2005.

BRASIL. Lei de 25 de março de 1824. Constituição do Império do Brasil. Disponível em:<http://www.planalto.gov.br/ccivil_03/constituicao/constituicao24.htm>. Acesso em: 30 fev. 2014.

BRASIL. Lei $\mathbf{n}^{\circ}$ 16, de 12 de agosto de 1834. Alterações e adições á Constituição Política do Império. Disponível em: <http://www2.camara.leg.br/legin/fed/lei/18241899/lei-16-12-agosto-1834-532609-publicacaooriginal-14881-pl.html>. Acesso em: 01 mar. 2016. 
CRUZ, Mariléia dos Santos. Escravos, forros e ingênuos em processos educacionais e civilizatórios na sociedade escravista do Maranhão no século XIX. Araraquara: UNESP, 2008, 195 f. Tese (Doutorado em Educação) - Programa de Pós-Graduação em Educação Escolar, Faculdade de Ciências e Letras, Universidade Estadual Paulista, Araraquara, 2008.

FARIA FILHO, Luciano de. Instrução elementar no século XIX. In: LOPES, Eliane Marta Teixeira; FILHO, Luciano de Farias; VEIGA, Cynthia Greive (org). 500 anos de educação no Brasil. 3 ed. Belo Horizonte: Autentica, 2007.

MARANHÃO. 17 de dezembro de 1849. Livro de Leis e Resoluções da Assembleia Legislativa Provincial. Secretaria da Província. Reg. fl. 76 v. Setor Códices: APEM.

MOURA, Laércio D. A educação católica no Brasil. 2 ed. São Paulo: Edições Loyola, 2000.

VEIGA, Cynthia Greive. Escola pública para os negros e os pobres no Brasil: uma invenção imperial. Revista Brasileira de Educação. V 13, n. 39 set./dez. 2008.

VIVEIROS, Jerônimo de. Apontamentos para a história da instrução pública e particular do Maranhão. Revista de Geografia e História. São Luís, 1953. 


\section{A UTILIZAÇÃO DE FOTOGRAFIAS COMO FORMA DE PRESERVAÇÃO E DISSEMINAÇÃO DA HISTÓRIA E MEMÓRIA LOCAL NA CIDADE DE CORRENTE (PI)}

Tefischer Huanderson Soares Sousa ${ }^{77}$

$77 \quad$ Bibliotecário, Historiador e mestrando em educação - Coordenador da Biblioteca do Instituto Federal do Piauí - Campus Corrente. E-mail: tefischer@ifpi.edu.br 


\section{INTRODUÇÃO}

Com o surgimento da internet, as informações são disseminadas e expostas das mais variadas formas, no entanto, percebe-se que a sociedade atual tem dado, cada vez mais, pouca importância para memória histórica, sejam eles através de museus, bibliotecas, arquivos e fotografias, principalmente em cidades do interior do país. Essa pesquisa foi realizada com o intuito de estudar as fotografias e seu impacto como instrumento de preservação e disseminação da história e memória local na cidade de Corrente (PI). Percebe - se a falta de conhecimento da população brasileira acerca da história da cidade ao qual residem e sua implicação para os dias atuais. Na cidade de Corrente, estado do Piauí, existem duas escolas muito antigas, uma desta, com mais de 100 anos de existência, que educaram e ainda educam uma grande parcela da população residente na cidade.

As fotografias antigas da cidade, principalmente da década de 70 e 80 mostrando o rio Corrente, principal rio de cidade e responsável pela subsistência dos habitantes ao longo dos anos, na qual evidencia seu processo de transformação ao longo dos anos e também fotos antigas e modernas das escolas Mercedário São José (Escola Católica) e Instituto Batista Correntino - IBC (Escola Protestante).

O problema desta pesquisa reside no fato da cidade de Corrente $(\mathrm{PI})$, ocorrer um desconhecimento por parte das novas gerações sobre a história da mesma, principalmente, no tocante a preservação dos rios que cortam a cidade, uma vez que este rio é a principal fonte de vida e possibilita a renda de muitas pessoas, seja através da agricultura, pecuária, etc. Com o passar dos anos, muitos habitantes, principalmente idosos mantêm os registros da memória local, muitas memórias orais e pouco fotográficas, na impossibilidade desses registros serem perdidos e que se percam importantes informações sobre a história da local essa pesquisa se faz importante.

A pesquisa neste artigo pode ser definida como bibliográfica, bem como, de fundamentação teórica. Foi - se utilizado leituras, a partir de livros, artigos e fontes eletrônicas. Cervo, Bervian e da Silva (2007, p.61) afirma que a pesquisa bibliográfica "constitui o procedimento básico para os estudos monográficos, pelos quais se buscam o domínio do estado da arte sobre determinado tema". Mostrou - se imagens da cidade de Corrente nas décadas de 70 e 80 em comparação com as de 2019.

\section{5}


Essa comparação foca em mostrar o rio Corrente e também foi mostrado imagens das escolas da região.

Como objetivo geral, estar o de proporcionar um conhecimento sobre a cidade de Corrente $(\mathrm{PI})$, através do resgate de fotografias com o intuito de preservação e disseminação dessas imagens e seu impacto na preservação da memória e história local. Como objetivos específicos temos: proporcionar o conhecimento da história de Corrente, resgatar o conhecimento há cerca da memória local através de imagens fotográficas, contribuir para a salvaguarda, preservação e posterior disseminação dessas informações.

A relevância do trabalho se dar na constatação de dois problemas principais: o primeiro no fato de ter poucos registros fotográficos acerca da história da cidade, exceto, em algumas casas de famílias tradicionais da região, percebendo essa dificuldade em preservação de memória local, pensou - se em utilizar as fotografias existentes para a difusão dessa história para a população em geral. O artigo se apresenta de modo que se perceba sucintamente as definições e objetivos da memória, da fotografia, posteriormente, abordamos a metodologia utilizada, os resultados alcançados, bem como, as considerações finais.

\section{DESENVOLVIMENTO}

\subsection{Fotografia}

A fotografia atualmente não é apenas uma fonte de informação, mas também, um registro histórico que fica para a posteridade. A fotografia pode retratar o modo de vida de um lugar, as roupas que as pessoas vestem, a expressão e o estado emocional no momento em que a mesma é tirada, resumindo, a fotografia é um retrato da realidade. Com as redes sociais, as fotografias ganharam enorme importância, uma vez que, é possível registrar todos os momentos da vida, inclusive os mais banais, como o momento que se escova os dentes, vai ao banheiro, realiza refeições, etc.

A humanidade caminhou, fez progressos, partiu da tradição oral, para as pinturas rupestres, com o surgimento da escrita, as imagens passaram a ser retratado em quadros perpetuando a representação da figura humana em suas diferentes fases: infância, mocidade e velhice ao longo dos anos. Os irmãos Claude e Joseph

\section{6}


Nicéphore Niepce desenvolveram uma prensa litográfica de ar quente, movida a motor, que Ihes permitiu produzir imagens fidedignas da realidade, as quais tinham as tonalidades invertidas, ou seja, o preto em lugar do branco, o daguerreótipo se tornou muito popular e sua patente foi comprado pelo governo francês em 1839.

Embora, existisse uma controvérsia sobre a data da primeira fotografia, na qual os Franceses afirmam que foi em 1822, entretanto, nos demais países se consideram que a primeira fotografia só foi apenas em 1826. Com a invenção da câmera fotográfica, a fotografia ganhou toda a atenção da sociedade e já era possível retratar tudo que acontecia ao redor, desde uma festividade religiosa, bem como casamento, passeios na praia, a infância, a vida escolar, formaturas, a morte, as guerras, etc. $A$ fotografia proporcionou a preservação da memória de vida de uma sociedade, também possibilita lembrar-se de bons momentos, outros nem tanto, ou seja, ela inspira ao rever situações passadas e suas mais variadas emoções.

Em seu início, a fotografia não era um produto barato e seu processo de confecção era bastante trabalhoso, bem como seu transporte, como demonstra Freund (1976, p.29):

A exposição para a sensibilização das chapas metálicas do daguerreótipo poderia durar até meia hora e, logo no início, o invento era consumido unicamente por alguns ricos aficionados e pensadores que podiam adquirir esse "luxo". O procedimento de Daguerre era bastante desconfortável. Em primeiro lugar a placa metálica, sensibilizada pela luz, não podia ser utilizada sem uma prévia exposição a vapores de iodo. A dificuldade principal consistia em que não se podia preparar a placa um pouco mais que antes de usá-la e tinha que ser revelada em seguida depois da exposição à luz solar. Além de não produzir cópias, apenas uma única imagem por exposição, o equipamento era pesado, podendo chegar ao peso de 50 quilogramas, e nesse período, o gênero de maior demanda era o retrato. No final de 1839, os primeiros aperfeiçoamentos fizeram que o peso chegasse a 14 quilogramas, e em 1840 inventores conseguiram diminuir os custos. "As placas que um ano antes foram vendidas por 3 ou 4 francos, custavam agora de 1 a 1,5 francos.

Segundo estimativas, na Europa, especificamente em Paris, duas mil câmeras fotográficas e 500 mil placas no século XIX foram comercializadas. Como toda invenção humana, com o passar dos anos ela passou por um processo de modernização, tentando reduzir seus custos e aumentar sua durabilidade e eficiência. Mais seu sucesso não foi apenas na Europa segundo o Freund(1976), "a daguerreotipia teve êxito considerável, na América do Norte foi onde foi mais bem sucedido, em 1850 já 
existiam dois mil daguerreótipos. Em 1853, calcula-se em três milhões de fotogradias tomadas por ano".

Os aperfeiçoamentos e pesquisas também resultaram em novos processos, entre eles a calotipia, desenvolvida por William Henry Talbot, que passou a usar papel como suporte ao invés de chapa metálica, e que gerava um negativo, do qual era possível fazer cópias positivas.

Nesse mesmo período, em 1854, o francês Disdéri criou a carte de visite (1), formato de apresentação de imagens de tamanho reduzido $(9,5 \times 6$ $\mathrm{cm}$ ), montada sobre um cartão rígido de cerca de $10 \times 6,5 \mathrm{~cm}$. Anos depois, surgia outro formato de retrato: a carte cabinet, criado na Inglaterra em 1866, que tinha o mesmo tipo de apresentação em um tamanho superior - 9,5×14 cm em cartões de 11×16,5 cm (VAZQUEZ, 2002, p.55).

Com o aparecimento de outras técnicas fotográficas e formas de se tirar fotografia, a democratização com relação ao acesso começou a ser pensada, principalmente para fins comerciais, como existia uma população imensa e apenas alguns privilegiados desfrutava dessa invenção a fotografia ganhou o público. Para Carvalho (2008, p.229) " com o surgimento do retrato fotográfico de busto - cabine-portrait e ao democratizar o retrato de corpo inteiro, o cartão de visita se desgatou, po ser pequeno, portátil e barato, o cartão de visita penetrou nas também nas camadas baixas.

Para fins acadêmicos, no século XIX, a corrente historiográfica que era predominante na época era o positivismo, que para registros e estudos históricos se concentrava apenas em documentos e estes seriam as únicas fontes confiáveis para representar a história, portanto, na época de seu surgimento a fotografia não seria uma fonte confiável para os estudos científicos.

Muitos consideram a fotografia como um texto, uma fonte de informação aceita sobretudo nas pesquisas acadêmicas e profissionais para Mauad (2004, p. 22 - 25) "os textos visuais, inclusive a fotografia, são resultados de um jogo de expressão e conteúdo que envolve, necessariamente, três componentes: o autor, o texto, propriamente dito, e um leitor". O autor seria aquele que tira as fotos, o produtor da mesma; o texto, seria a imagem em si; já o leitor é aquele que analisa ou interpreta a fotografia tirada ao analisar a imagem.

Atualmente, com o surgimento da Escola de Annales, Nova História e Micro-História a fotografia é usada em várias pesquisas científicas e se tornou um instru-

\section{8}


mento valioso no estudo da história e seus desdobramentos. Entretanto, ainda existem opiniões divergentes a respeito da fotografia. Para Oliveira (2008, p.33):

As fotografias possuem elementos que questionam sua expressão máxima da realidade apresentada. Em primeiro lugar, por se tratar de um recorte da realidade, sua dimensão visual reduz a escala de observação. Não vemos todo o cenário no qual a fotografia foi tirada. No momento do clique, existe uma escolha, a eleição de um elemento (o foco), desprezando-se todos os outros elementos. Em segundo lugar, existe a visão do fotógrafo, que é aquele que escolhe determinado objeto em detrimento de outros. O que o leva a privilegiar um objeto e não outro faz parte de uma bagagem: sua cultura, sua formação, seus gostos, o trabalho sob encomenda, a sociedade em que vive.

Recuero, afirma a relevância das fotografias em nosso cotidiano, mas também pondera sobre como deve ser utilizada:

Se antes a fotografia ilustrava galerias, informava em jornais e anunciava o consumível, agora busca no seio da ciência o lugar que lhe foi reservado: Não ser arte, mas conter a arte. Não ser realidade, mas conter a realidade. "Não ser ciência, mas mostrar a ciência". A utilização da fotografia em trabalhos científicos não é uma tarefa simples. Ela necessita do estabelecimento de normas e maneiras de obtenção e procurem dotar as imagens de um valor científico, que esbocem uma norma de leitura e que tentem formar um uso adequado não só como ilustrações de pesquisa, mas como parte da pesquisa com o mesmo valor da textualidade sígnica da escrita. (RECUERO, 2005, p. 1869 - 1879)

A fotografia como fonte de informação científica também é muito criticada pelas manipulações ao qual ela está sujeita, na qual alguns foram realizadas ao longo da história como a do vitoriano Gustave Rejlander (1813 - 1875), na qual retrata um menino de rua com frio e, na verdade, a foto teria sido encenada e o menino teria sido pago pelo autor. Burke (2004) alertar e questiona muitas vezes a legitimidade e o anonimato desses fotógrafos e como isso acaba dificultando a contextualização da imagem, afirma que "a identidade dos fotografados e dos fotógrafos é muitas vezes desconhecida, e as próprias fotografias, em muitos casos são separadas do projeto ou do álbum ao qual era inicialmente mostradas e acabam em arquivos ou museus".

Outros autores também reforçam essa criticidade com relação à fotografia e traz ressalvas sobre a questão da imagem como Rodrigues:

A fotografia em si, os filmes em si não representam, tanto quanto qualquer documento velho ou novo, uma prova de verdade. Toda a crítica externa e interna que a metodologia impõe ao manuscrito impõe, igualmente, ao filme. Todos podem, igualmente, ser 'montados', todos podem conter ver- 
dades e inverdades. Existe, naturalmente, para cada espécie de fonte, uma possibilidade especial de falsificação, e conhecê-las é a tarefa de críticos de fontes. (RODRIGUES 1978 apud KOSSOY 1980, p. 29)

Percebemos o caminho histórico da fotografia e seus desafios, bem como sua possibilidade de ser aceito ou não como objeto de pesquisa científica. A fotografia passou do analógico, com tubos, para o digital, percebe - se uma melhora em sua imagem, seus recursos, bem como a praticidade de uso e de todos os valores. Hoje, temos em celulares, câmeras que nem o Daguerre e Niepce imaginaram e este recurso só tende a evoluir cada vez mais ao longo dos anos.

\subsection{A fotografia pelo viés da memória}

A cidade é um ambiente heterogêneo, encontram-se de tudo, prédios, cidades, pessoas, rodeados de praças, palcos, etc. Têm suas transformações culturais, sociais, econômicas e suas paisagens urbanas. A fotografia urbana retrata todos esses cenários e suas mais diversas manifestações, esses lugares retratam uma história passada que reflete no presente e também são carregados de memória.

Podemos enxergar a fotografia como um suporte da memória como peça ativa no processo, para Georges Didi-Huberman (2012, p. 209), "nunca a imagem se impôs com tanta força em nosso universo estético, técnico, cotidiano, político, histórico". Existem duas categorias de memória, tendo em vista o foco das fotografias em âmbito urbano, a memória material e a imaterial, entende-se como memória material: avenidas, ruas, prédios, etc. Como memória imaterial engloba as atividades culturais humanas dentro daquele ambiente, tais como gírias, festas religiosas, danças, etc.

Reforçando esses conceitos, segundo o Instituto do Patrimônio Histórico e Artístico Nacional (Iphan, 2019):

Os bens tombados de natureza material podem ser imóveis como as cidades históricas, sítios arqueológicos, paisagísticos e bens individuais; ou móveis, como coleções arqueológicas, acervos museológicos, documentais, bibliográficos, arquivísticos, videográficos, fotográficos e cinematográficos. Os bens culturais de natureza imaterial dizem respeito àquelas práticas e domínios da vida social que se manifestam em saberes, ofícios e modos de fazer; celebrações; formas de expressão cênicas, plásticas, musicais ou lúdicas; e nos lugares (como mercados, feiras e santuários que abrigam práticas culturais coletivas). 


\subsection{Memória}

Como a fotografia registra todo o modo de vida das pessoas dentro de uma sociedade, bem como as paisagens e monumentos dentro de uma cidade. Ao passar dos anos, fica-se na cabeça as lembranças dos momentos vividos junto aos álbuns de fotografias familiares ou fotos armazenadas em museus, bibliotecas e arquivos para posterior consulta ou pesquisa, tudo isso se constitui na memória, neste tópico iremos enfatizar seu conceito, tipos e sua importância para a formação histórica da memória de um local.

Aristóteles (1989, p.690), afirma que Memória:

É, portanto, nem percepção, nem concepção, mas sim um estado de afeição de um destes condicionados por um intervalo de tempo. Como já observamos não existe memória do presente no presente, pois o presente é objeto apenas de percepção, e o futuro de expectativas, porém o objeto da memória é o passado. Toda memória, portanto, implica um intervalo de tempo. Consequentemente apenas os animais que percebem o tempo lembra e o órgão no qual percebem o tempo também no, qual eles lembram.

Para Halbwachs (1990, p. 26) o conceito de memória é de que ela não é um processo de evocação individual, mas sim uma construção coletiva: "nossas memórias permanecem coletivas, e elas nos são lembradas pelos outros, mesmo que se trate de acontecimentos nos qual só estivemos envolvidos, e com objetos que só nós vimos. É porque, em realidade, nunca estamos sós". O autor enfatiza que as memórias não pertencem apenas ao indivíduo, mas também, a todos a sua volta é uma construção coletiva.

Hoje, percebemos esse conceito bem mais visível, uma vez que as fotos tiradas de câmeras celulares têm o intuito de retratar não só o momento de uma pessoa como uma paisagem e tentar retratar todo o contexto a sua volta. A memória individual é a maneira com que cada indivíduo armazena e guardar suas experiências vividas e seu modo de vida. Já a coletiva o contexto e experiência vividos por outros participantes destes momentos. As memórias correspondem às diversas experiências possíveis, e sua aquisição é modulada pelas emoções, pelo nível de consciência, pelo estado de ânimo do indivíduo, bem como por fatores orgânicos como a idade, diversas enfermidades e até mesmo pela nutrição, entre outros (GREGG, 1976, p. 24).

No Brasil, o Ministério da Educação - MEC (1999) já reconheceu a essa necessidade, como podemos comprovar no seguinte trecho dos Parâmetros Curriculares Nacionais para o Ensino Médio: 
O direito à memória faz parte da cidadania cultural e revela a necessidade de debates sobre o conceito de preservação das obras humanas. A constituição do Patrimônio Cultural e sua importância para a formação de uma memória social e nacional sem exclusões e discriminações é uma abordagem necessária a ser realizada com os educandos, situando-os nos "lugares de memória" construídos pela sociedade e pelos poderes constituídos, que estabelecem o que deve ser preservado e relembrado e o que deve ser silenciado e "esquecido" (MEC, 1999).

As memórias individuais e coletivas se complementam e afetam - se reciprocamente. Já para Halbwachs (1990) "nossa memória individual está impregnada das memórias daqueles que nos rodeiam, de maneira que o nosso rememorar (reconstruir o passado) e as maneiras como percebemos e vemos o que nos cerca se constituem a partir desse emaranhado de experiências alheias". Outro tipo importante de memória é a memória construtiva que são as lembranças construídas de acordo com nossas vivências.

O mesmo autor reforça seu conceito de memória individual e memória coletiva afirmando que:

Se essas duas memórias se penetram frequentemente; em particular se a memória individual pode, para confirmar algumas de suas lembranças, para precisá-las, e mesmo para cobrir algumas de suas lacunas, apoiar-se sobre a memória coletiva, deslocar-se nela, confundir-se momentaneamente com ela; nem por isso deixa de seguir seu próprio caminho, e todo esse aporte exterior é assimilado e incorporado progressivamente à substância. A memória coletiva, por outro, envolve as memórias individuais, mas não se confunde com elas. Ela evolui segundo suas leis, e se algumas lembranças individuais penetram algumas vezes nela, mudam de figura assim que sejam recolocadas num conjunto que não é mais uma consciência pessoal. (HALBWACHS, 2004, p. 57 - 58)

As memórias individuais são produtos dos quadros ou estruturas sociais que antecedem o indivíduo e mesmo os pensamentos e sentimentos mais pessoais buscam sua fonte nas circunstâncias sociais que os envolvem (HALBWACHS, 1990, p. 36). Kessel (2003) aborda que, a memória individual e coletiva nos conta que se alimentam e têm pontos de contato com a memória histórica e são socialmente negociadas, mas têm origens e características diferentes, seja pelo tipo de informação que guardam, seja pelo tempo que conseguem abarcar, seja pelas funções que ocupam.

A memória individual e coletiva sofre grandes transformações, aparecem o surgimento da imprensa. Para Le Goff: 
A imprensa revolucionou lentamente a memória ocidental. Revolucionou-a ainda mais lentamente na China, que, apesar de ter descoberto a imprensa no século IX da nossa era, só veio a utilizar os processos mecânicos ocidentais no século XIX. A imprensa, mesmo não podendo agir massivamente na China, teve efeitos importantes sobre a memória, pois os chineses imprimiram tratados científicos e técnicos que aceleraram e alargaram a memorização e o saber. A teoria clássica da memória formada na Antiguidade greco-romana foi modificada pela escolástica, que teve um lugar central na vida escolar, literária e artística da Idade Média, vindo a desaparecer quase completamente no movimento humanista. (LE GOFF, 1994, p. $457-466)$

Portanto, nas sociedades orais, a manutenção da memória era através de pessoas mais velhas, chamadas de homens de memória Também aparece os dicionários e enciclopédias como forma de preservação da memória coletiva para as futuras gerações, também surge a fotografia que proporciona uma maior preservação da memória individual e coletiva das sociedades. A educação através da memória é de uma importância muito grande na medida que um povo sem memória, são pessoas que possivelmente não irão entender o contexto social em que se encontra, como chegaram até aquele ponto, os erros que foram cometidos no passado podem ser repetidos no futuro.

\section{RESULTADOS E DISCUSSÃO}

Como resultado está o da preservação e difusão da história e memória local na cidade de Corrente (PI) com base nas fotografias expostas tamanho seu desconhecimento acerca da história da cidade ao qual nasceram e cresceram. Isso poderá contribuir para uma geração de cidadãos mais crítica com relação ao seu contexto histórico e sua importância para com a sociedade.

Estamos em um momento da humanidade que se valorizar em demasia o novo, e se esquece do velho, de onde viemos, como surgiu a humanidade, os caminhos pela qual passou seus erros e acertos que fizeram com que chegássemos aos dias atuais. O resgate da história e da memória seja através de fotografias ou qualquer outro meio, ou técnica de preservação da mesma se faz necessário, uma vez que, sem entender nossa história, iremos nos tornar em pessoas que não sabem o contexto que vivem porque que estão enfrentando os problemas do presente, vão passar pelos anos como se nunca tivessem existido para a humanidade.

\section{3}


No próximo passo desta pesquisa se pretende digitalizar essas fotografias, bem como aumentar o acervo das mesmas e armazenar no sistema Pergamum de Biblioteca do Instituto Federal do Piauí - Campus Corrente, na qual esses materiais poderão ser preservados e disseminados para o maior número de usuários possíveis.

\section{REFERÊNCIAS}

ARISTÓTELES. On Memory and Reminiscence.In: Works of Aristotle. Chicago: university of Press, 1989.

BURKE, Peter. Testemunha ocular: história e imagem. Bauru, SP: EDUSC, 2004.

CARVALHO, Vânia Carneiro de. Gênero e artefato: o sistema doméstico na perspectiva cultural material - São Paulo 1870 - 1920. São Paulo: EDUSP, 2008.

CERVO, A.L; BERVIAN, P.A.; SILVA, R. Metodologia Científica. 6.ed. São Paulo: Pearson Prentice Hall, 2007.

DIDI-HUBERMAN, Georges. Ante el tempo: Historia del arte y anacronismo de las imágenes. Argentina: Adriana Hidalgo Editora, 2008.

FREUND, Gisele. La fotografia como documento social. 2 reimpr. Barcelona: Gustavo Gili, 1976.

GREGG, Vernon. Memória Humana. Rio de Janeiro: Zahar Editores, 1976.

HALBWACHS, Maurice. A memória coletiva. São Paulo: Vértice, 1990.

IPHAN. Disponível em: <http:// http://portal.iphan.gov.br/>. Acesso em 17 de out. de 2019.

KESSEL, Zilda. A construção da memória na escola: um estudo sobre as relações entre memória, história e informação na contemporaneidade. São Paulo: USP, 2003.

LE GOFF, Jacques. História e memória. São Paulo: Editora da UNICAMP, 1994.

MAUAD, A. M. Fotografia e História: possibilidades de análise. In: CIAVATTA, M.; ALVES, N. (orgs). A leitura de imagens na pesquisa social: História, comunicação e educação. São Paulo: Cortez, 2004.

MEC. Parâmetros Curriculares nacionais - Ensino Médio: ciências humanas e suas tecnologias. Brasília: Ministério da Educação/Secretária de Educação Média e Tecnologia, vol. 4, 1999.

\section{4}


OLIVEIRA, Rita Barreto de Sales. A fotografia como memória na vida dos candangos. Brasília, 2008. Trabalho de Conclusão de Curso (Mestrado em Ciência da Informação - Universidade de Brasília (UNB), Brasília, 2008.

RECUERO, Carlos Leonardo. $O$ uso da imagem fotográfica em trabalhos científicos. In: Fragmentos de Cultura, Goiânia, v. 15, n. 12, dez. 2005.

RODRIGUES, José Honório. Teoria da história do Brasil: introdução metodológica. 5.ed. São Paulo: Nacional, 1978.

VASQUEZ, Pedro Karp. A fotografia no Império. Rio de Janeiro: Jorge Zahar, 2002.

\section{Anexos}

Figura 1 - Rio Corrente anos 70

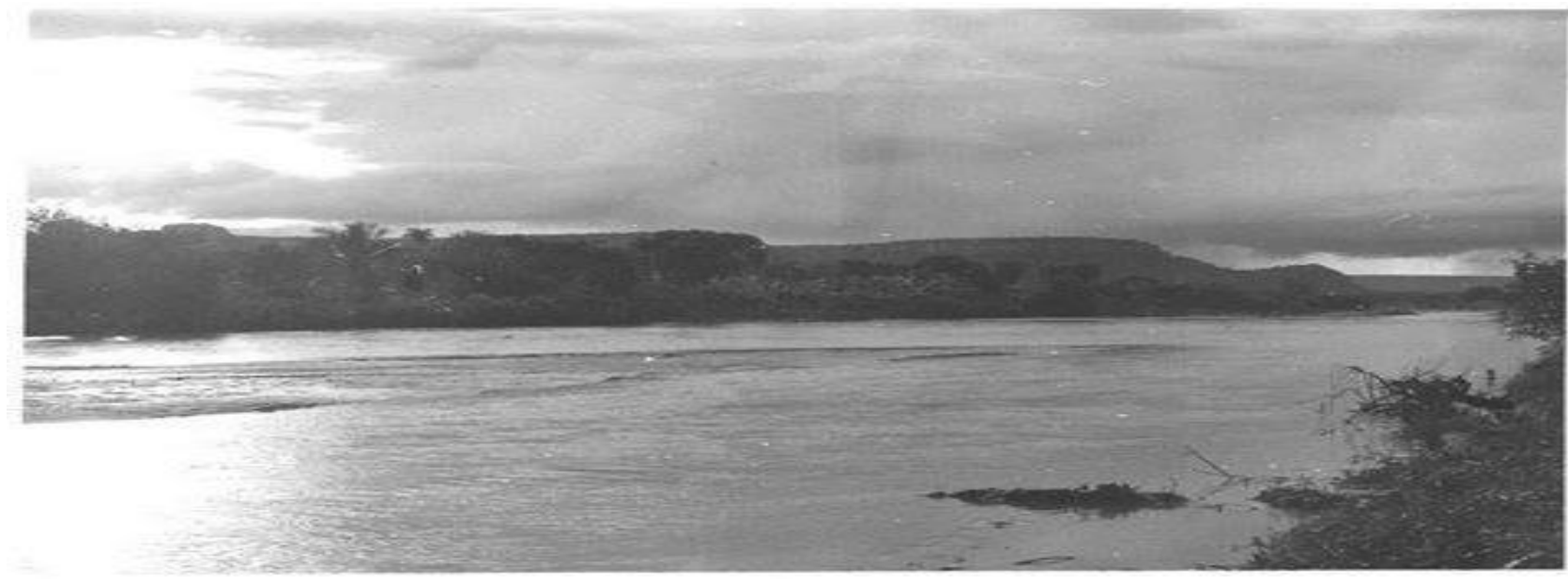

Figura 2 - Rio Corrente, anos 80.

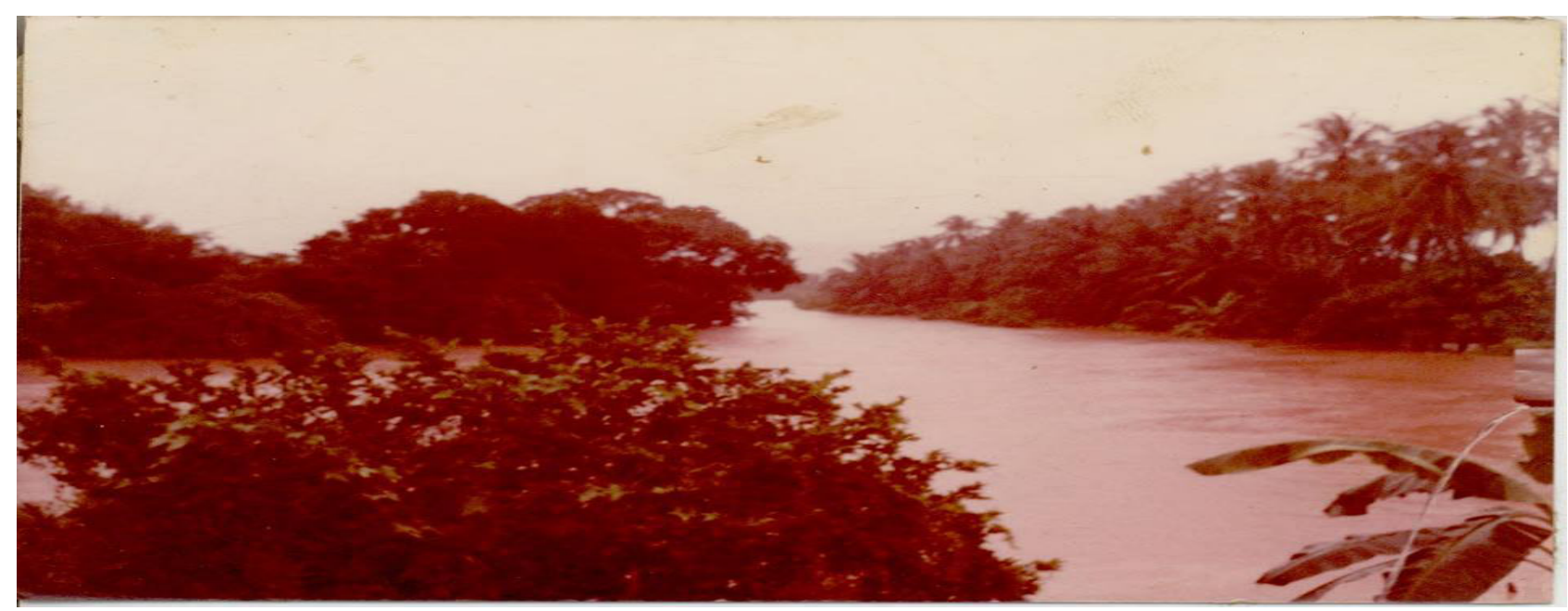


Figura 3 - Rio Corrente (2019)

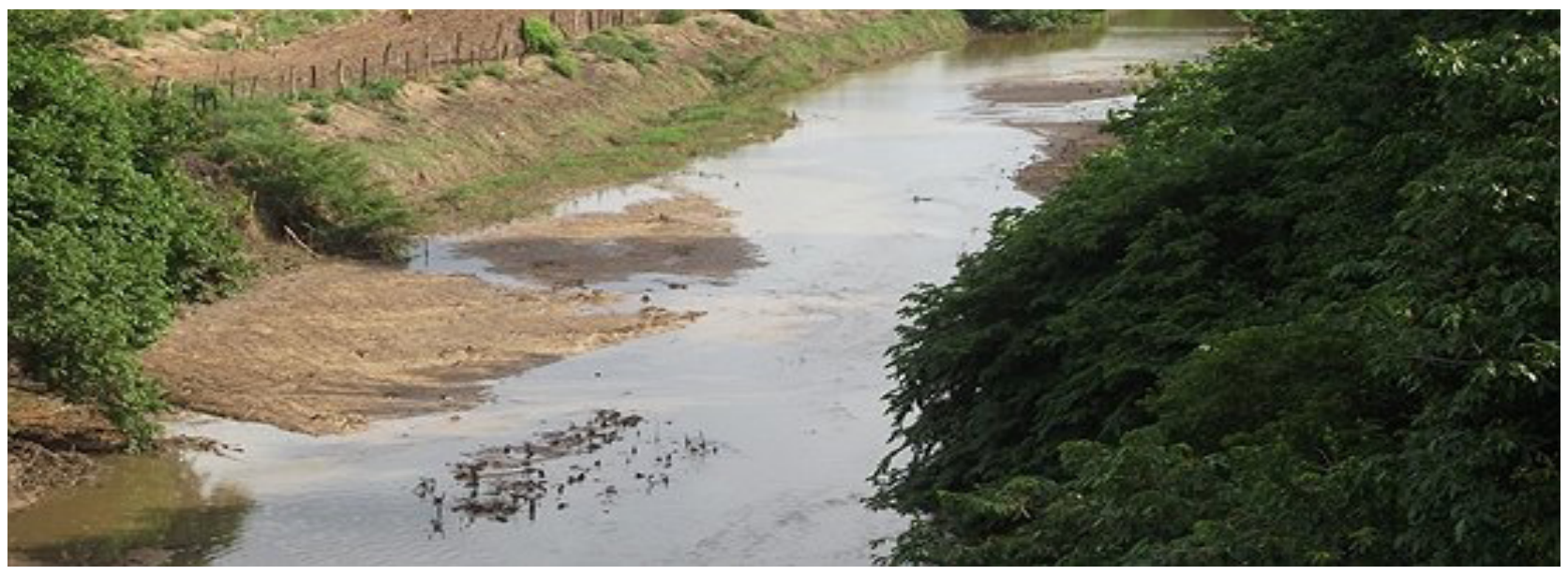

Figura 4 - Alunos no inicio do colégio São José (década de 70)

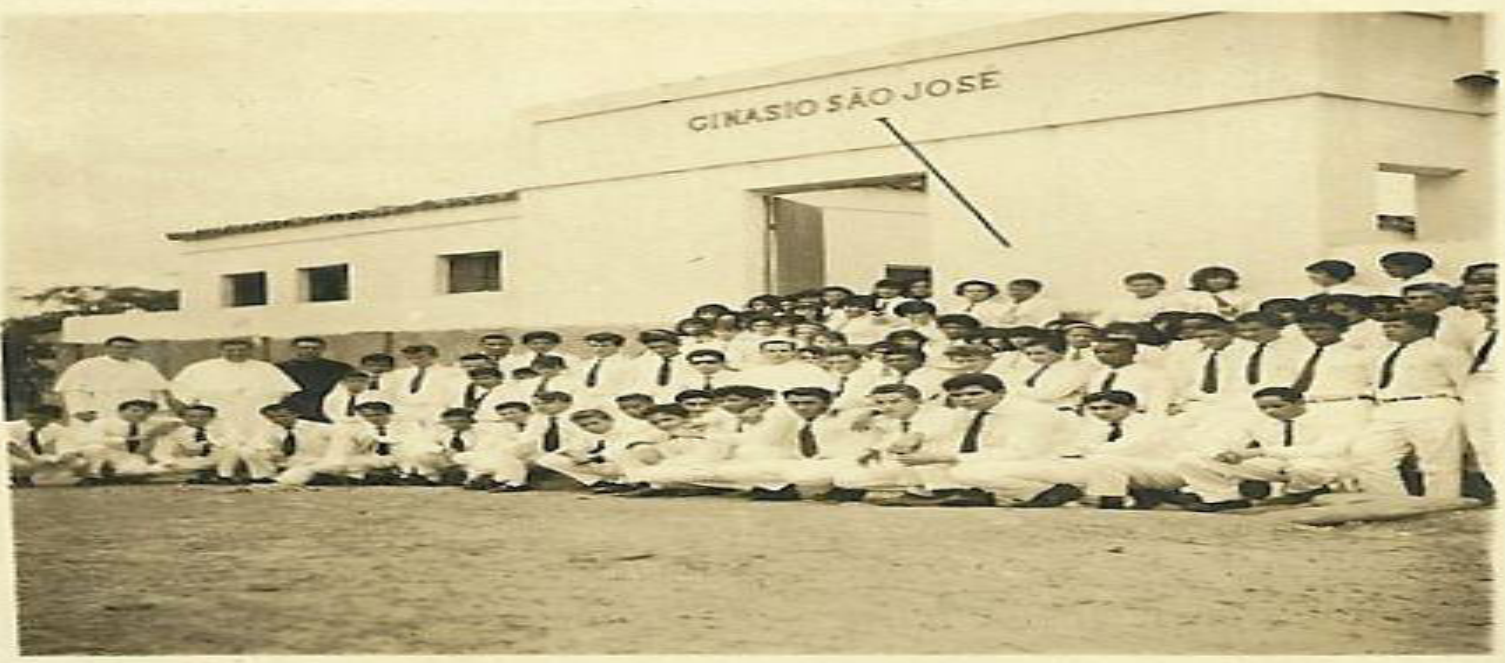

Figura 5 - Desfile da Independência - Colégio São José (década de 70)

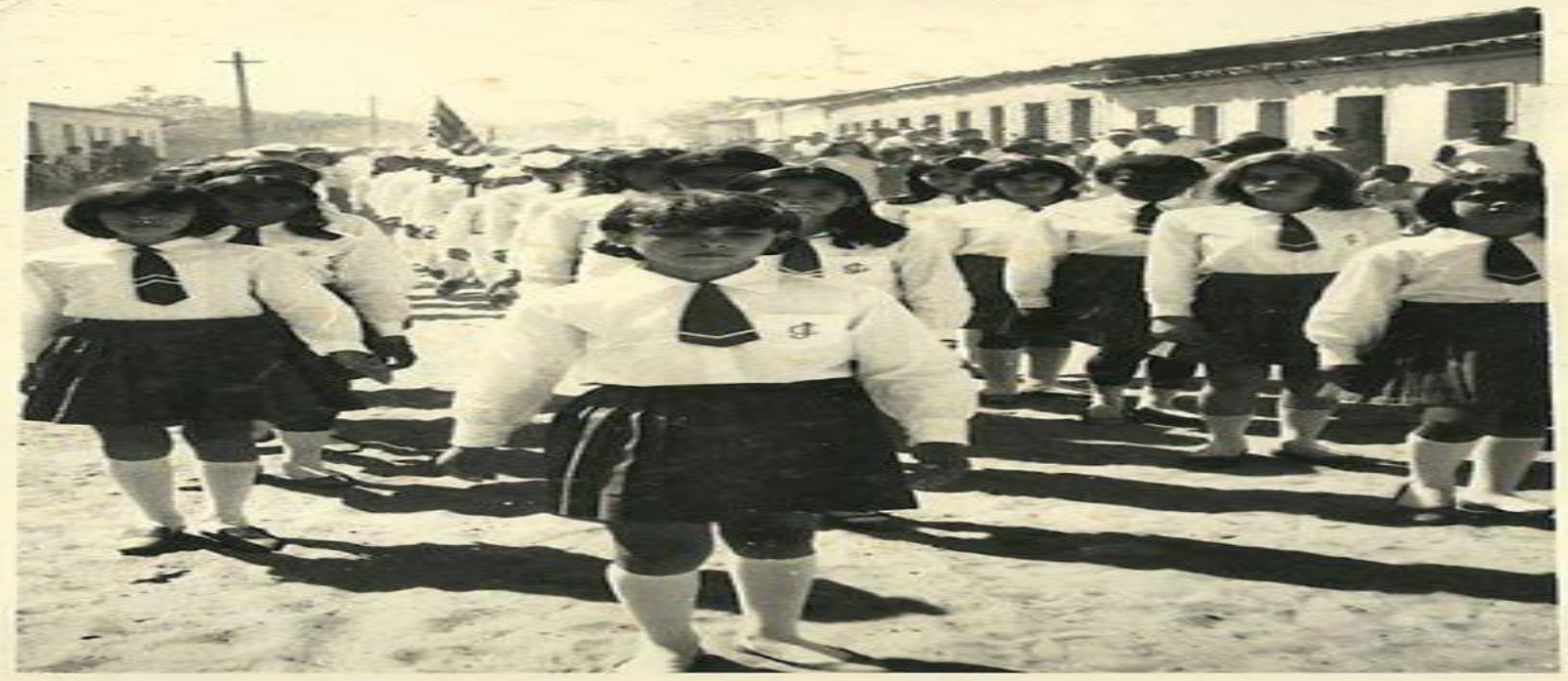


Figura 6 - Alunos do colégio São José (2019)

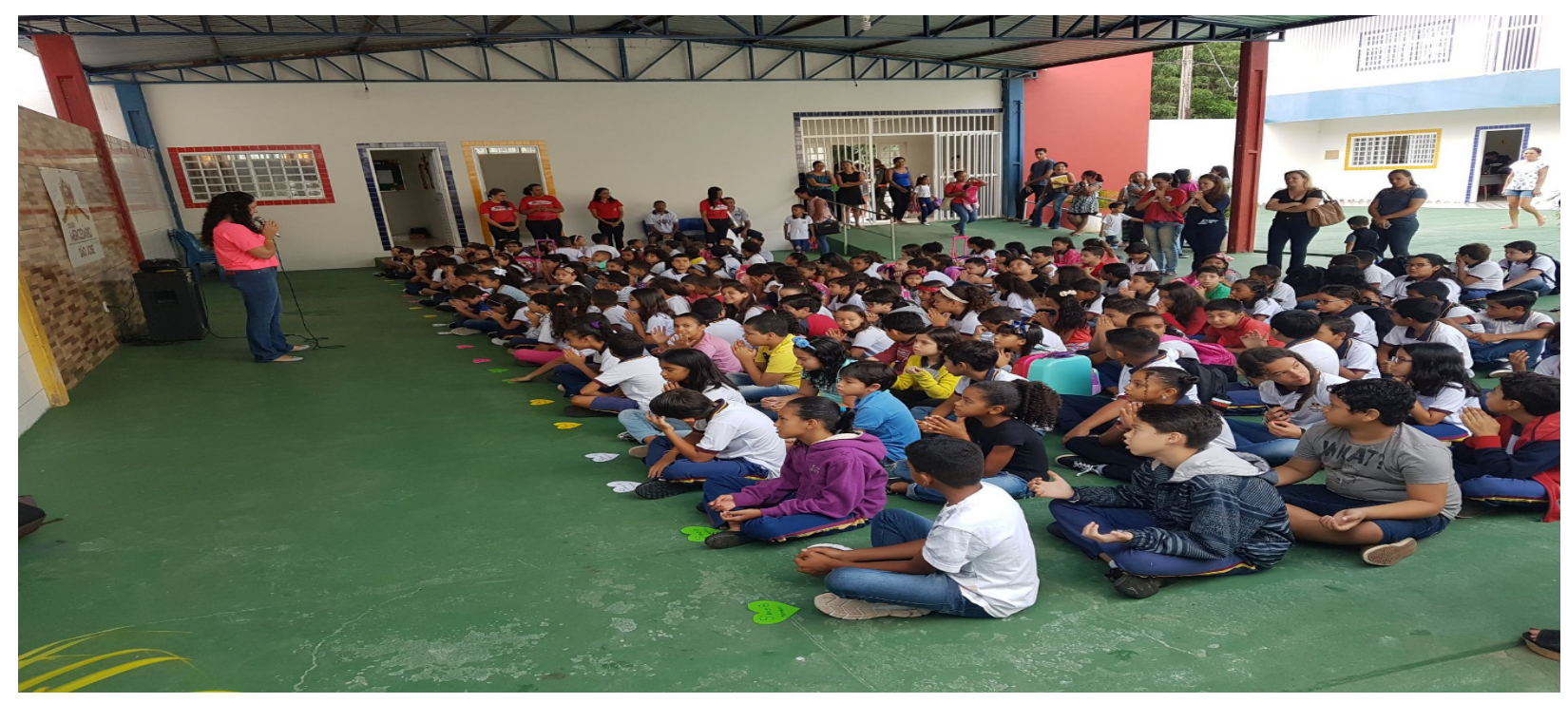

Figura 7 - Desfile da Independência (ano 2019)

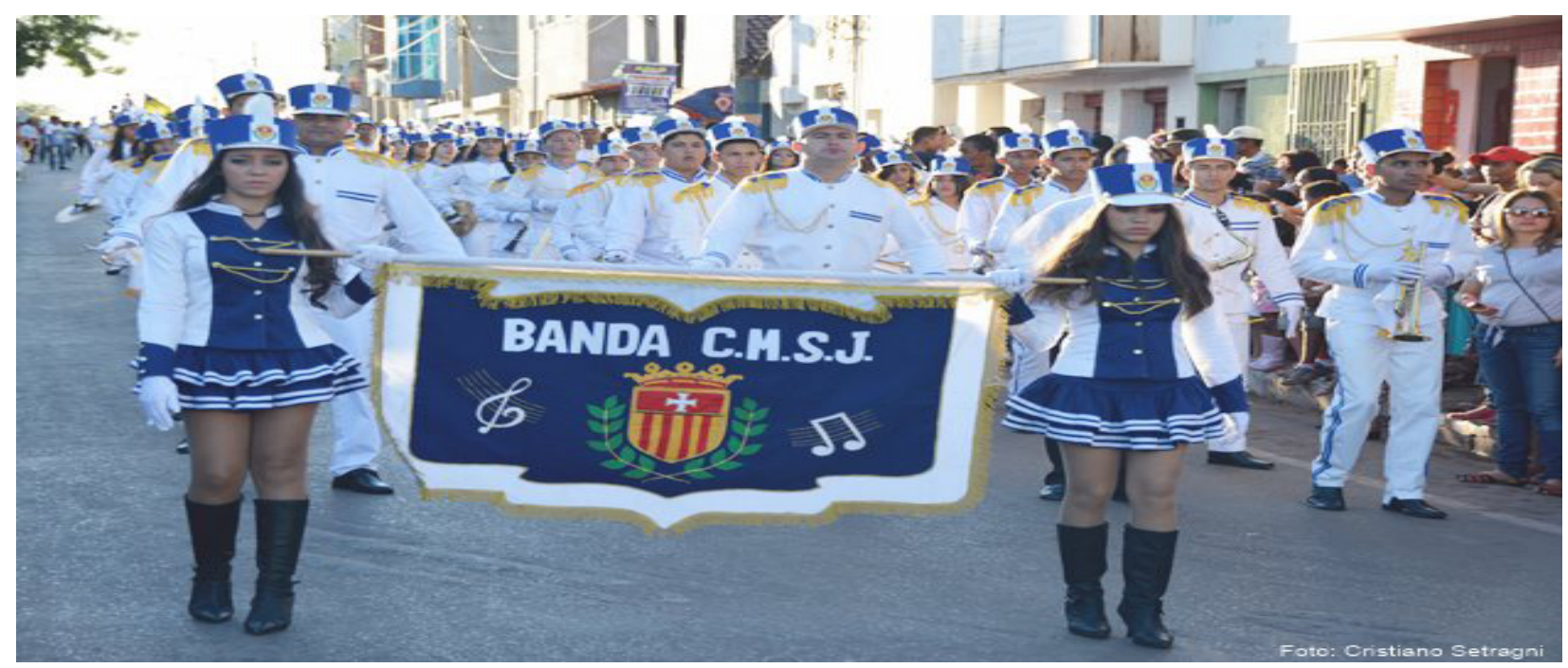

Figura 8 - Alunos do Colégio IBC (década de 70)

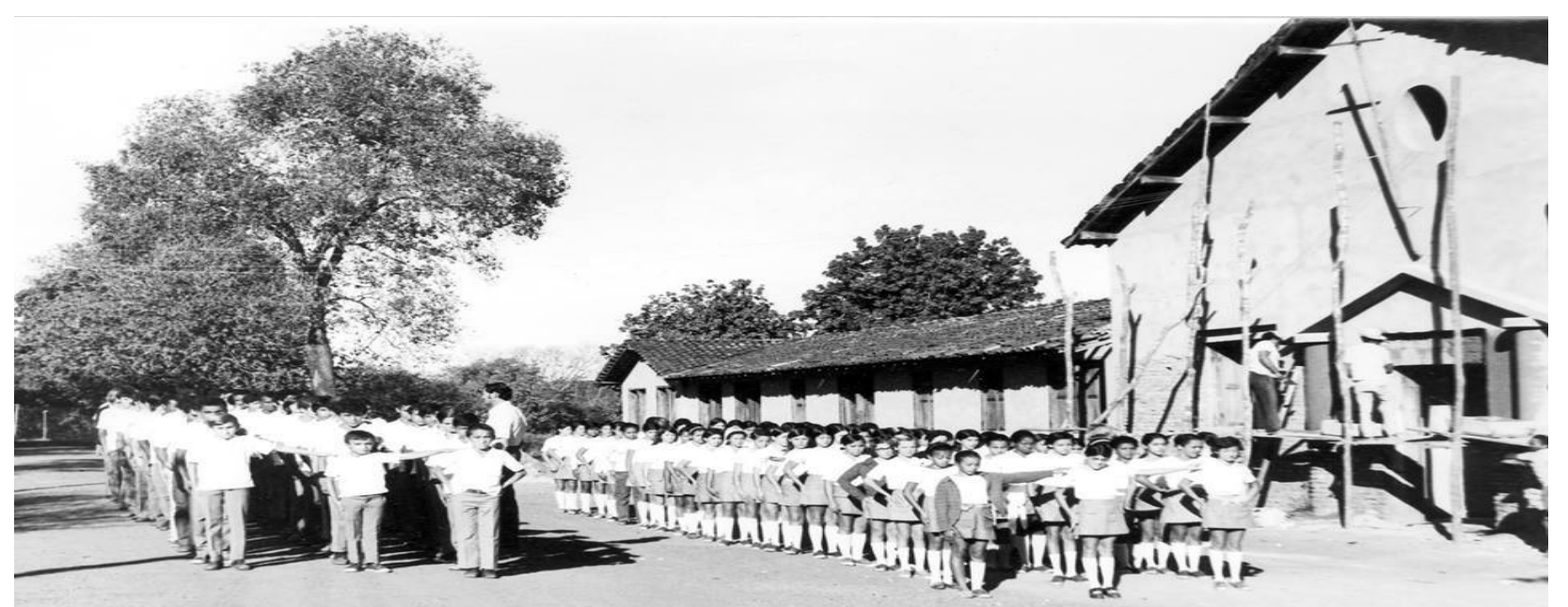


Figura 9 - Desfile da Independência - IBC (década de 80)

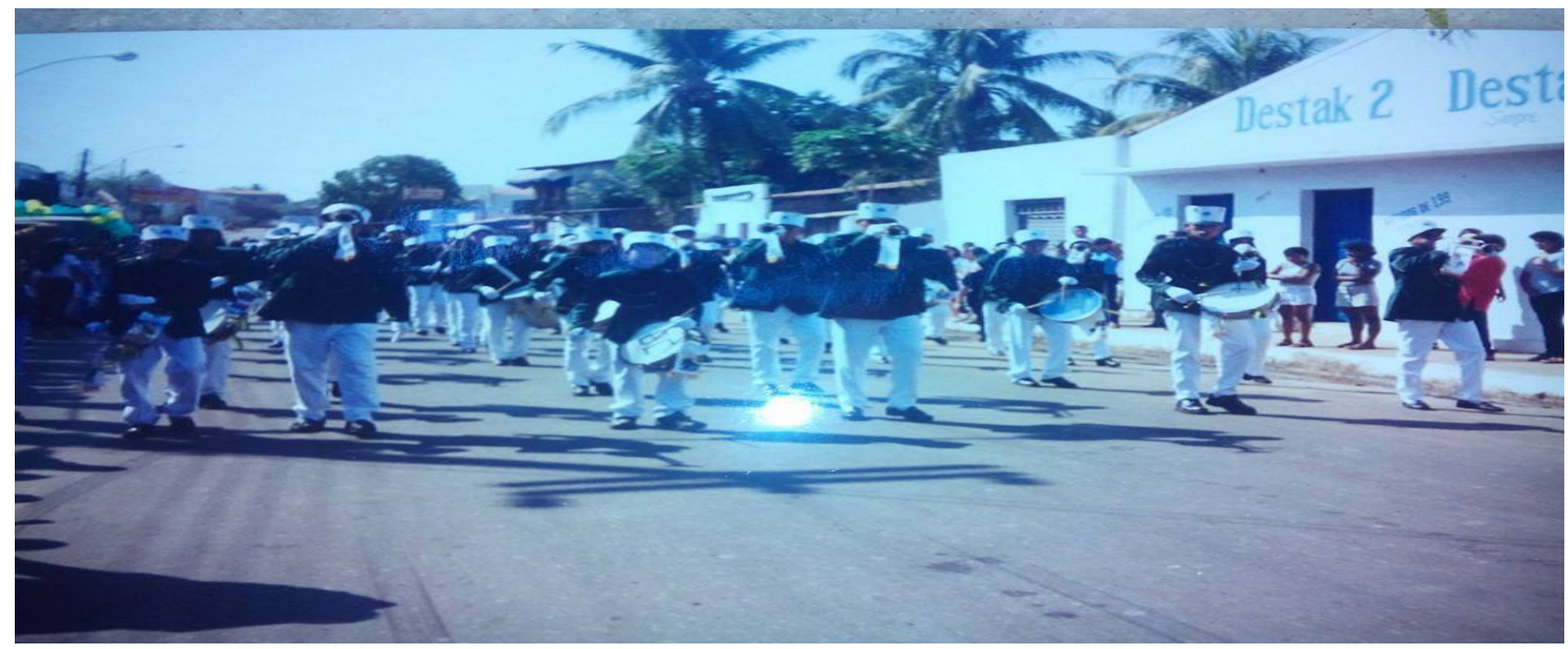

Figura 10 - Desfile da independência (ano 2019)

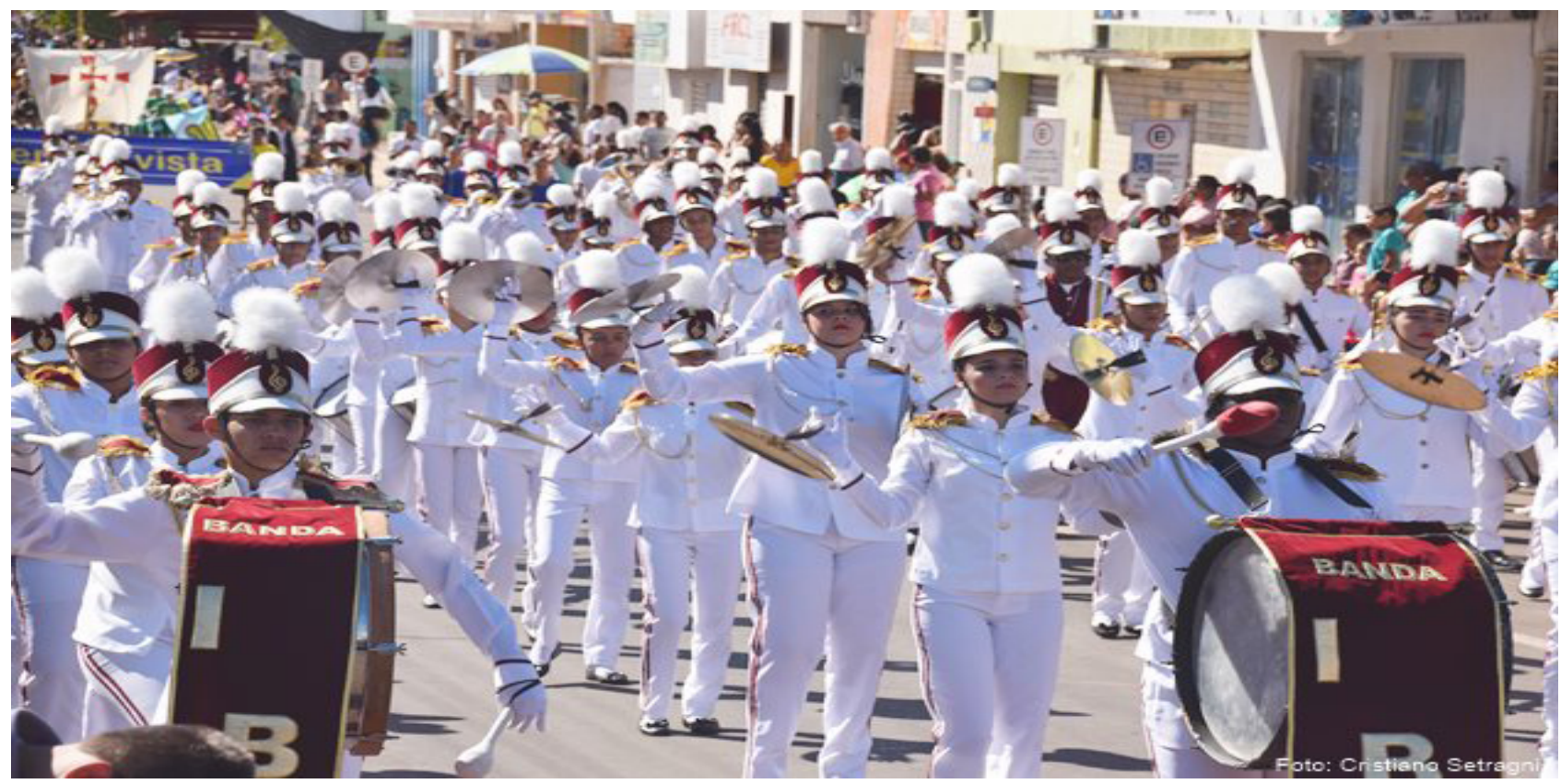




\section{SOBRE OS ORGANIZADORES}

\section{LEANDRO ANTÓNIO DOS SANTOS}

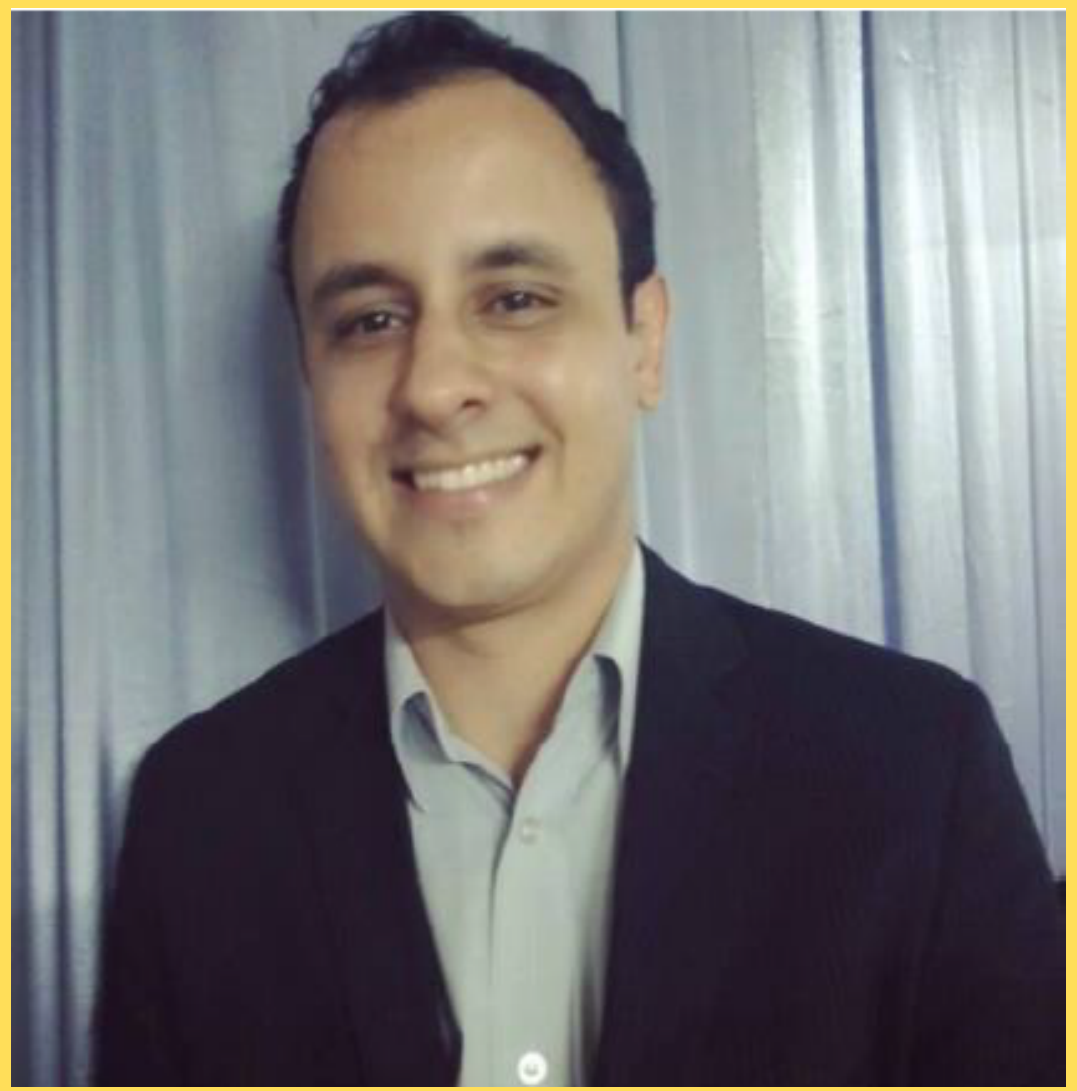

Possui graduação em História pela Universidade Federal de Goiás (2013), e mestrado em História Social pela Universidade Federal de Uberlândia (2016) e doutorado em História Social pela Universidade Federal de Uberlândia (2020). Têm experiência na área de História, com ênfase em História do Brasil República, com destaque para a Belle Époque, Anos Dourados, a cidade do Rio de Janeiro na criação literária, público e privado, historicidade da experiência literária, honra e moralidade da família carioca nas representações jornalísticas e teatrais de Nelson Rodrigues, imprensa brasileira, Jornal Última Hora e teatro brasileiro. É filiado a Associação Nacional de História - ANPUH. 


\section{RANNA IARA DE PINHO CHAVES ALMEIDA}

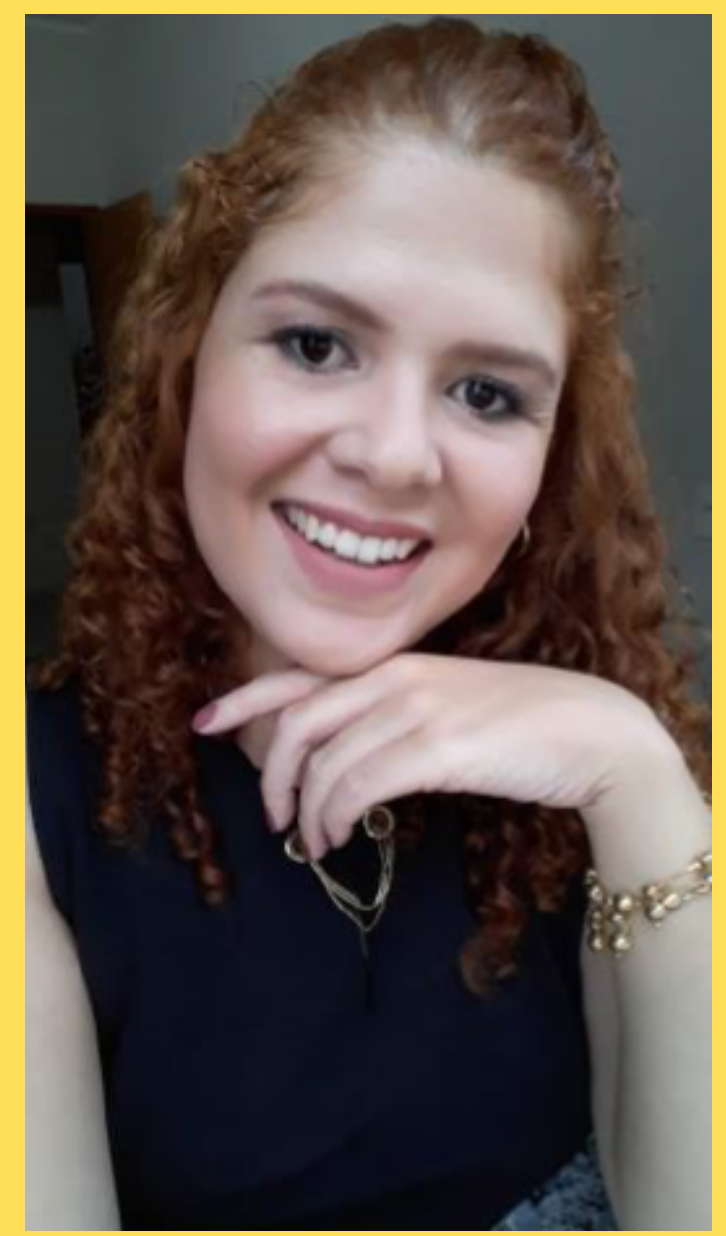

Mestre em Ciências Sociais pela Universidade Federal de Uberlândia, Especialista em Ensino de Humanidades pelo Instituto Federal Goiano, graduada em Ciências Sociais com habilitações em Licenciatura e Bacharelado em Antropologia pela Universidade de Brasília e Pedagoga pelo Instituto Federal Goiano. Exerceu atividades técnicas no Distrito Sanitário Especial Indígena de Mato Grosso do Sul (MS/SESAI/ DSEI - MS). Leciona as disciplinas de Sociologia e Filosofia na rede pública e privada do estado de Goiás. 
A $A$ R T C $O$

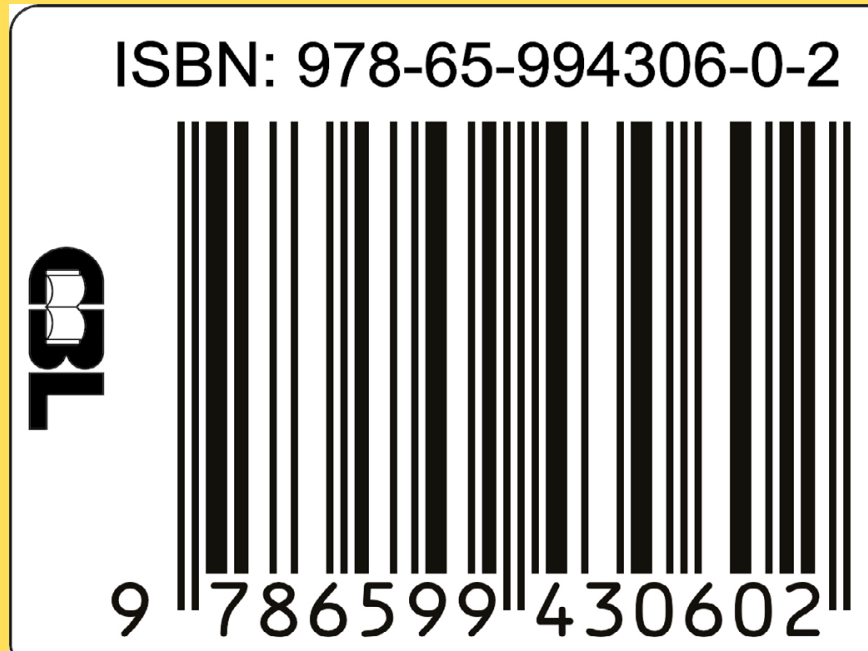

